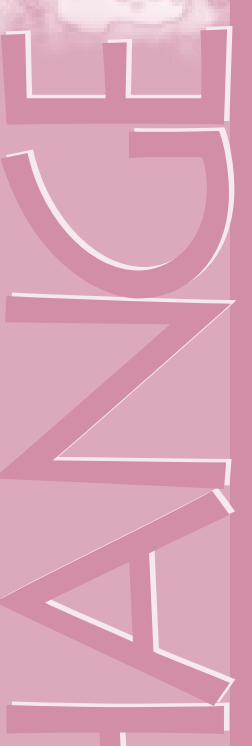

\title{
The formation of Croatian national identity
}

\section{A centuries-old dream}

\author{
$\star$ \\ ALEX J. BELLAMY
}




\section{THE FORMATION OF CROATIAN NATIONAL IDENTITY}

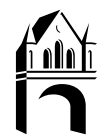




\section{EUROPE}

\section{IN \\ CHANGE}

already published

Committee governance in the European Union

THOMAS CHRISTIANSEN AND EMIL KIRCHNER (EDS)

Theory and reform in the European Union, 2nd edition

DIMITRIS N. CHRYSSOCHOOU, MICHAEL J. TSINISIZELIS,

KOSTAS IFANTIS AND STELIOS STAVRIDIS

German policy-making and eastern enlargement of the EU during the Kohl era

Managing the agenda?

STEPHEN D. COLLINS

The European Union and the Cyprus conflict

Modern conflict, postmodern union

THOMAS DIEZ

The time of European governance

MAGNUS EKENGREN

Greece in a changing Europe

Between European integration and Balkan disintegration?

KEVIN FEATHERSTONE AND KOSTAS INFANTIS (EDS)

An introduction to post-Communist Bulgaria

Political, economic and social transformation

emil giatzidis

The new Germany and migration in Europe

BARBARA MARSHALL

Turkey's relations with a changing Europe MELTEM MÜFTÜLER-BAC

Turkey: facing a new millennium

Coping with intertwined conflicts

AMIKAM NACHMANI

The road to the European Union, volume 2

VELLO PETTAI AND JAN ZIELONKA (EDS)

Righting wrongs in Eastern Europe

ISTVAN POGANY

The road to the European Union, volume 1

The Czech and Slovak Republics

JACQUES RUPNIK AND JAN ZIELONKA (EDS)

Two tiers or two speeds?

The European security order and the enlargement of the European Union and Nato JAMES SPERLING (ED.)

Recasting the European order

Security architectures and economic cooperation

JAMES SPERLING AND EMIL KIRCHNER

The emerging Euro-Mediterranean system

DIMITRIS K. XENAKIS AND DIMITRIS N. CHRYSSOCHOOU 


\section{ALEX J. BELLAMY}

\section{THE FORMATION OF CROATIAN NATIONAL IDENTITY}

A centuries-old dream?

MANCHESTER UNIVERSITY PRESS

Manchester and New York

distributed exclusively in the USA by Palgrave 
Copyright (c) Alex J. Bellamy 2003

The right of Alex J. Bellamy to be identified as the author of this work has been asserted by him in accordance with the Copyright, Designs and Patents Act 1988.

Published by Manchester University Press

Oxford Road, Manchester M13 9NR, UK

and Room 400, 175 Fifth Avenue, New York, NY 10010, USA

www.manchesteruniversitypress.co.uk

Distributed exclusively in the USA by

Palgrave, 175 Fifth Avenue, New York, NY 10010, USA

Distributed exclusively in Canada by

UBC Press, University of British Columbia, 2029 West Mall,

Vancouver, BC, Canada V6T 1Z2

British Library Cataloguing-in-Publication Data

A catalogue record for this book is available from the British Library

Library of Congress Cataloging-in-Publication Data applied for

ISBN 071906502 X hardback

First published 2003

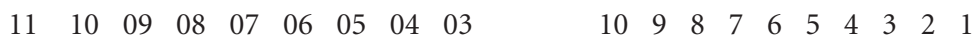

Typeset in Minion with Lithos

by Koinonia, Manchester

Printed in Great Britain

by Biddles Ltd, Guildford and King's Lynn 
For my Dad:

David John Bellamy 
Alex J. Bellamy - 9781526137739 Downloaded from manchesterhive.com at ๑4/26/2023 01: 04 : ๑९AM via free access 


\section{CONTENTS}

Acknowledgements

viii

Note on pronunciation and language

Introduction

1 National identity and the 'great divide' $\quad 7$

2 Re-imagining the nation $\quad 20$

3 The Croatian historical statehood narrative 32

4 Contemporary accounts of Croatian national identity 65

5 The nation in social practice I: economy, football and Istria 104

6 The nation in social practice II: language, education and the Catholic Church

7 Conclusion: competing claims to national identity 171

Bibliography 185

$\begin{array}{ll}\text { Index } & 207\end{array}$ 


\section{AcKnowledgements}

I was able to complete this project because of the encouragement, love and support of many people. I owe a massive debt of gratitude to my mum Ann Jude and stepfather Robert Jude, who have given me unquestioning support. This book would certainly not have been possible without the financial support of the Economic and Social Research Council and the practical assistance afforded by the Department of International Politics at the University of Wales, Aberystwyth.

My greatest intellectual debt is owed to Steve Smith. It was an immense privilege to have Steve's help and advice in putting this project together. To those who know his work it may come as a surprise when I use the well-trodden phrase that his influence can be seen on every page. But it can. He instilled clarity where there was none and often knew my position better than I knew it myself. The wealth of expertise at Aber was astounding and humbling. In particular I think of Nick Wheeler, a great friend and intellectual influence. I had the pleasure of working with Nick on several projects and his wide ranging and deep understanding of world affairs helped me form views on many issues. This book also benefited from the insights and expertise of many others at Aberystwyth; especially, Ken Booth, Steve Hobden, Ian Clark, Mike Foley, Mick Cox, Tim Dunne, Lucy Taylor, Colin Wight, and Richard Wyn-Jones.

Paul Williams, Rob Dixon, and Danda Kroslak deserve special mention for providing intellectual and social support throughout this project. They are treasured friends and brilliant scholars.

My frequent visits to Croatia were made not only enlightening but also incredibly enjoyable by a number of people. First and foremost my thanks go to Daria Mateljak Bartulin. The majority of people I met in Croatia, I met thanks to Daria. The whole Mateljak family - Joe, Lea, Ivo, Tonka, and Andrija - were wonderful hosts. Particularly helpful was Renata Pekorari at the Croatian documentation centre and Nevenka Čučković and all at the Institute of International Relations in Zagreb. Davor Čurkuć provided excellent hospitality in Zadar, and many useful bits of paper. Vjeran Katunarić provided intellectual and social help and influenced my thinking on all manner of things Croatian. Thanks also to: Ognjen Čaldarović, Ivan Grdešić, Nenad Zakošek, Nenad Klapčic, Friar Ilija Živkovic, Anthony London, Vesna Puhovski, Alida Matković, Zdenko Franić, Bozo Kovačević, Boris Hajoš, Branko Gračanin, Zarko Domljan, Ivan Ivas, Zlatko Popić, Sasa Djačanin, and Dubravko Škiljan. There are many others, and I am grateful to you all.

I would like to thank Tony Mason and Richard Delahunty and all at Manchester University Press for their help and support.

Finally, Sara deserves a special and final mention. She knows why. 


\section{Note ON PRONUNCATION AND LANGUAGE}

Language was an important political tool throughout former Yugoslavia in the 1990s. The choice of words and spellings in this book is not meant to reflect any political orientation. The language used in contemporary Croatia is labelled 'Croatian' throughout, except when 'Serbo-Croatian' is specifically referred to (to describe the official language of the Socialist Federative Republic of Yugoslavia). I use 'Croatian' simply because that it what most people in Croatia call their language.

The choice of place names is also a political choice. Unless referring to the labels used by specific writers, I use the modern Croatian names for places. Thus, the Dalmatian hinterland that was occupied by Serb rebels between 1991 and 1995 is referred to as the 'Lika', which was the geographical expression for the area after the dissolution of the Habsburg military frontier (Vojna Krajina) in the nineteenth century. However, when referring to the political status of the territory held by the Serbs in the first half of the 1990s, I label it as the 'so-called Krajina', to intimate the name given to it by the Serbs and the fact that this name was never legitimised either by the Croats or the international community.

Most often, I simply reproduce words as found, as they can tell us things about the person or group using them. This gets confusing with the use of the Croatian ' $/ \bigoplus^{\prime}$ ', which is sometimes also expressed as 'dj'. Following my basic rule, I use ' $\partial$ '. In writing people's names I either follow the standard norm or adopt the spelling preferred by the person referred to. Most foreign writers spell 'Tuðman' as 'Tudjman'. I maintain the original spelling in quotes, followed by $[s i c]$ to demonstrate that the spelling change is deliberate. Again, I do not wish to make any political point with my choice of letters and spellings.

Croatian is a phonetic language with each letter constituting a different sound. Thus:

A as in English a in father.

$\mathrm{B}$ as in $\mathrm{b}$ in bed.

$\mathrm{C}$ as in ts in cats.

Ć a sound between ch in reach and $\mathrm{t}$ in tune.

$\check{C}$ as in ch in reach.

$\mathrm{D}$ as in $\mathrm{d}$ in $\operatorname{dog}$.

Dž as in $\mathrm{j}$ in John.

$\mathrm{Dj}$ as a sound between $\mathrm{d}$ in duke and dg in bridge.

$Đ$ as Dj.

$\mathrm{E}$ as in $\mathrm{e}$ in let.

$\mathrm{F}$ as in $\mathrm{f}$ in full.

$\mathrm{G}$ as in $\mathrm{g}$ in good.

$\mathrm{H}$ as in Scottish ch in loch.

$\mathrm{I}$ as in English I in machine.

$\mathrm{J}$ as in $\mathrm{y}$ in yet. 
$\mathrm{K}$ as in $\mathrm{k}$ in kite.

$\mathrm{L}$ as in 1 in look.

$\mathrm{Lj}$ as in 11 in million.

$\mathrm{M}$ as in $\mathrm{m}$ in man.

$\mathrm{N}$ as in $\mathrm{n}$ in net.

$\mathrm{O}$ as in o in not.

$\mathrm{P}$ as in $\mathrm{p}$ in pet.

$\mathrm{R}$ as in $\mathrm{r}$ in run, slightly rolled.

$\mathrm{S}$ as in ss in glass.

$\breve{S}$ as in sh in she.

$\mathrm{T}$ as in $\mathrm{t}$ in tap.

$\mathrm{U}$ as in $\mathrm{u}$ in rule.

$\mathrm{V}$ as in $\mathrm{v}$ in veil.

$\mathrm{Z}$ as in $\mathrm{z}$ in zebra.

$\check{Z}$ as in $\mathrm{S}$ in pleasure.

(Pronunciation table based on J. R. Lampe, Yugoslavia as History: Twice There Was a Country (Cambridge: Cambridge University Press, 1996), pp. xix-xx.) 


\section{TNTRODUCTION}

What did it mean to be Croatian in the 1990s? As the Republic of Croatia enters its second decade as an independent state, with a new president and a new government for the first time, this book asks whether sentiments of Croatian national identity have changed and, if so, how and why. General theories of nations and nationalism are unhelpful when it comes to addressing particular cases, principally because very few cases adhere to the accounts they offer. I do not intend to rehearse these arguments here or to explore the relative merits of different theories with regards to Croatia. Instead, I propose a multi-layered approach to studying contemporary Croatian national identity. Adopting Paul James' theory of 'abstract communities', I argue that national identity is constituted by the interaction of three levels of social abstraction. The first level is an abstract level of 'big stories' that distinguish the nation from other nations. In and of themselves, such stories have little meaning in contemporary contexts. Therefore the second level looks at the political and intellectual elites who attempt to make sense of these 'big stories' in order to legitimise particular political programmes in the contemporary context. However, national identity derives its power from being embedded in individual subjectivity. Thus the narratives of national identity articulated by political and intellectual elites are manifested and constantly reinterpreted in social practice. None of the three levels can be prioritized because they are mutually constitutive. That is, social practices within nations make no sense outside the narratives of the first and second levels. The first, most abstract, level is politically meaningless without contemporary interpretation. The power of national identity derives from its existence at the nexus of all three levels. It is constituted by the first, contextualised and mobilised by the second, and embedded by the third. This is a constant process of contestation, without an end point, in which social practices in the everyday inform revisions at the levels of abstraction above.

With regards to Croatia, I argue that at the most abstract level Croatian national identity is constituted by the narrative of historical statehood (see Chapter 3). During the 1990s competing political parties and intellectuals (the second level) mobilised and reinterpreted narratives of historical statehood (the first level) in order legitimise their political programmes. The ruling party (the HDZ, Hrvatska Demokratska Zajednica - Croatian Democratic Union) made use of the bureaucratic power of the state to enforce its particular understanding of Croatian national identity. Although such ideas enjoyed salience during the wars of 1991-95 there were always sites of resistance to this dominant account of national identity. As the 1990s passed, disjunctures 
developed between what the government said being Croatian meant and many people's experiences of actually being Croatian. This prompted the construction of sites of resistence where alternative conceptions of national identity were articulated and practised. By the end of the 1990s, there were so many disjuntures and contradictions that the HDZ's perspective became untenable, even though it was backed by the bureaucratic power of the state. This provoked something of a paradigm shift in the 1999-2000 elections in which new, more Western and European, conceptions of Croatian national identity came to the fore.

My approach to understanding the formation of Croatian national identity in the 1990s is therefore broken into three parts. At the first and most abstract level are the 'big stories' of national identity that permeate the longue durée. These are the narratives and events that distinguish the Croatian nation from all other nations, ethnic groups and other types of social formation. I argue that in the case of Croatia these 'big stories' derived from the Croatian historical narrative and in particular from the claim to historic statehood. This is the claim that Croatia was formed as a nation by centuries of continuous statehood. Such a claim was made frequently in the past as well as in contemporary Croatia. These claims are explored in Chapter 3, which outlines the historical statehood narrative. Chapter 3 does not attempt to provide a 'history' of Croatia, its national identity, ${ }^{1}$ or a discussion of its national historiography. ${ }^{2}$ Instead, it attempts only to identify a narrative of Croatian historical statehood and briefly to demonstrate how it influenced earlier conceptions of Croatian national identity. The primary purpose of Chapter 3 , therefore, is to identify abstract conceptions of national identity that were interpreted and articulated by actors in the 1990s to legitimise their political programmes.

The second level draws on Radcliffe and Westwood's investigation of the 'internalisation' of national narratives, which is discussed in Chapter 2. It contends that in order to become salient in the present, the abstract claims and ideas that constitute the first level have to be made intelligible and relevant to the community that comprises the nation. National identities are not simply sets of abstract ideas but are also embedded in the material day-to-day lived experience of people. Thus the second level of analysis focuses on the explanations of national identity that were articulated by politicians, intellectuals and others in the 1990s. These explanations attempted either to mobilise the community around a particular political programme (be it a nationalist programme or not) or, as in the case of the dissident intellectuals attempted to challenge those programmes or deconstruct the 'big stories' of national identity. To that end, Chapter 4 focuses on competing ideas of national identity articulated in 1990s Croatia by the government and its supporters, opposition parties and dissident intellectuals.

The third level of analysis considers the ways that the ideas articulated in the first two levels were manifested and reinterpreted in social activity. Focusing on six case studies, the study at this level identifies contests about the meaning 
of national identity. It looks at how conceptions of national identity shape social practices and emphasises the complex, overlapping and contradictory nature of national identity. It shows how the ideas discussed in the first two levels are often rejected when subjects perceive a disjuncture between ideas and lived experience. This level focuses on attempts to enforce a narrow understanding of Croatian national identity and the many sites of opposition that it produced. Chapters 5 and 6 therefore consider six areas of social practice in order to provide a series of snapshots showing the way that competing conceptions of national identity were embedded in areas as diverse as regionalism, religion and sport.

In Croatia's first democratic elections, on 22 April 1990, the Communist Party was defeated by the nationally oriented HDZ. Although the HDZ did not campaign for independence, its main slogan 'it is for us to decide' left few in much doubt about its orientation. Once it assumed power in Yugoslav Croatia, the new government - while being overtly Croat-centric - did much to appease the central authorities in Belgrade. The Croatian territorial defence forces that had been created by Tito were partially disarmed at the bequest of the JNA (Jugoslavenski Narodna Armija - Yugoslav People's Army) and along with Slovenia the new government proposed a revised constitution that envisaged a confederal Yugoslavia. The President of the Republic of Serbia, Slobodan Milošević, rejected these plans. On 18 May 1991 Croatia held a referendum for independence and the result was an overwhelming endorsement of secession, though the country's 600,000 Serbs boycotted the vote. Almost simultaneously, on 25 June 1991, Slovenia and Croatia announced their disassociation from the Socialist Federative Republic of Yugoslavia (SFRY). However, both states had to wait another six months for recognition by the European Community. Finally, on 15 January 1992 they were recognised along with the Republic of Bosnia and Hercegovina and the Republic of Macedonia. ${ }^{3}$ By this time, one third of the territory of the Republic of Croatia had been captured by a combination of rebel Croatian Serbs fearful of the nationalist overtones of the HDZ and the JNA. The Croatian cities of Osijek, Vukovar and Borovo Selo had been flattened and the historic cities of Zadar and Dubrovnik severely damaged. ${ }^{4}$

The war in Croatia abated somewhat in 1992 with the deployment of the United Nations Protection Force (UNPROFOR) and the creation of a neutral zone between Croatia and rebel Serb territories (United Nations Protected Areas - UNPAS). The problems remained unresolved while world attention turned to the horrors of the war in Bosnia and Hercegovina. Although the agreement that allowed UNPROFOR to create the UNPAS in Croatia demanded that the rebel Serbs disarm and that weaponry and men belonging to the JNA be withdrawn to Serbia, neither happened. By 1995 the Croatian Army had significantly improved its strength and capability and launched a series of offensives to regain territories held by rebel Serbs. The largest of these offensives, Operation Storm (Oluja), began on 4 August 1995 and finished a few days later with the Croats having taken virtually all the territory previously occupied by 
rebel Serbs. A piece of territory along the Croatian-Serbian border remained in Serbian hands, but Milošević agreed to return this territory (Eastern Slavonia) at the Dayton peace conference in November 1995. The United Nations Transitional Authority in Eastern Slavonia (UNTAES) successfully managed this transition in $1997 .{ }^{5}$

Having twice won re-election, President Franjo Tuðman died on 10 December 1999. Less than a month later, his party (HDZ) was resoundingly defeated by an opposition coalition in parliamentary elections. A few weeks later, Stipe Mesić won the presidential elections. Mesić had been the last titular President of the SFRY and as a senior HDZ member had abandoned Tuðman's party in 1993 in protest against the Croatian government's support for the Bosnian Croat para-state of 'Herceg-Bosna' and the subsequent war between the Bosnian Croats and the Bosnian government. After a decade of attempting to answer the question of what it meant to be a Croat, the HDZ's control of the Croatian state unravelled in a matter of weeks.

To understand the formation of Croatian national identity in the 1990s we need to locate the discussion within wider concerns about the nature and origins of nationalism and national identity. This issue is addressed in Chapter 1 where I expose a number of problems with traditional approaches to the subject that have been shaped by the so-called 'great divide'. 'Nationalism studies' have been dominated by the 'Warwick debate' between Ernest Gellner and Anthony Smith, which was held at Warwick University on 24 October 1995. This debate formalised the 'great divide' between primordialists and modernists. On the one hand there are so-called primordialists (or 'ethnosymbolists' to use Smith's self-description) such as Anthony Smith who contend that nations can trace a lineage into antiquity. Different writers award different qualities to these histories. Smith, for example, suggests that the lineage need only be subjective, while others such as Clifford Geertz insist that it is physical and genealogical. The other side of the 'great divide' is populated by writers such as Ernest Gellner who insist that the nation was an entirely novel and revolutionary form of political community, one that claims an ancient heritage but which is actually a wholly modern construction. These approaches have received labels such as modernism, constructionism and instrumentalism and are as divergent as the labels suggest.

Aware of the problems with both positions in the aftermath of the Warwick debate, Anthony Smith and John Breuilly attempted to merge these paradigms into a synthesis. However, this 're-imagining' of the nation ultimately failed because both sides continued to cling on to their own axioms and truisms and thereby continued to talk past each other. This led writers such as Partha Chatterjee, Michael Billig and Paul James to bring new concerns to the field and point the debate in new directions: Chatterjee exposed the conceptual collusion between primordialism and modernism; Billig exposed the nation in everyday social activities and James insisted that the nation has to be understood as being located on several layers of social abstraction. This new thinking is incorporated 
here by developing Paul James' notion of 'abstract communities' and adapting three research questions outlined by Katherine Verdery. They are:

- How do people become national? (Adapted to be, how do people become Croats?)

- How is the nation symbolised? (Adapted to be, how is Croatian national identity expressed in contemporary symbolism and rhetoric?)

- How can we understand the intersection of the nation with other social operators? (Adapted to be, how are competing ideas about Croatian national identity manifested in different areas of social activity?)

The study of Croatian national identity begins by posing the question 'how do people become Croats?' and considering the Croatian historical narrative. Most contemporary Croatian politicians and intellectuals agree that Croatian national identity was shaped by the history of the Croats and in particular the tradition of statehood that Croatia ostensibly enjoyed, albeit in many guises. Although most commentators do not go as far as Franjo Tuðman and suggest that Croats shared a 'centuries-old dream' to have their own national state, there is widespread agreement that people became Croats primarily through a shared history and occupancy of a common state.

The book goes on to address the question of how Croatian national identity was represented and reinterpreted by symbols and rhetoric in the 1990s. It focuses on the ways in which politicians, intellectuals and others attempted to render abstract ideas of Croatian national identity more intelligible in order to win legitimacy for their political programmes. It begins by considering the dominant approach, which was the explanation of the meaning of Croatian national identity articulated by Franjo Tuðman and the HDZ. The concept of 'Franjoism' is introduced to explain the way in which abstract historical interpretation and public policy were married in an attempt to produce 'good Croats' in the mould of the President himself. However, Franjoism failed to monopolise the national imagination and there were alternative visions of what it meant to be Croatian. Other political parties understood national identity differently, as did dissident Croatian intellectuals such as Ivo Banac and Slavenka Drakulić. Throughout the 1990s, different interpretations of the Croatian historical narrative were articulated in order to mobilise 'the nation' behind one or other political programme or to challenge that mobilisation.

To address my third level of analysis, six case studies are then offered to consider how the process of internalisation brought national identity into contact with other social operators and forms of identity. Each study is of an area of social practice in Croatia. Each is primarily interested in the way that different ideas of national identity competed to be internalised in social practice and how they were challenged and reinterpreted during that process. The six case studies - of the national economy, football, the region of Istria, education, the Roman Catholic Church and the Croatian language - reveal the ways in which national identity has a material day-to-day quality as well as an abstract 
content. National identity becomes embedded in the lived experiences of national subjects. Although ideas about the nation can be seen in each of these areas, the meaning of what it was to be Croatian was constantly reinterpreted. Thus Chapters 5 and 6 identify many accounts of national identity that are laced with inconsistencies and discrepancies.

By considering national identity at different levels of abstraction it is possible to see processes of perpetual contest and (re)interpretation at work. It is also possible to identify ways in which ideas about identity have a practical and material resonance. Franjo Tuðman and the HDZ attempted, and failed, to resolve the meaning of Croatian national identity. Evidence for this is provided by the numerous alternative accounts that permeate this study and the crushing defeat of the HDZ in the 2000 parliamentary and presidential elections.

\section{Notes}

1 For a study of the socio-economic aspects of nation-building in Croatia see M. Gross, Počeci moderne Hrvatske. Neoapsolutizam u civilnoj Hrvatskoj i Slavoniji 1850-1860 (Zagreb: Globus, 1985).

2 Croatian national historiography has been characterised by swings between radical and conservative polemics. See M. Gross, Suvremena Historiografija: Korijeni, Postignuača, Traganja (Zagreb: Novi Liber, 1993).

3 Because the Greek government opposed the appropriation of the name Macedonia, which they claim is Greek, Macedonia was recognised as the 'Former Yugoslav Republic of Macedonia' or FYROM. Turkey recognises Macedonia by its constitutional name.

4 For an overview of these events see C. Cviić, An Awful Warning: The War in ExYugoslavia (London: Centre for Policy Studies No. 139, 1994).

5 See J. Gow, Triumph of the Lack of Will: International Diplomacy and the Yugoslav War (London: C. Hurst and Co., 1997), p. 283. 


\section{National identity and the 'great divide'}

According to Tom Nairn, 'the reason why the dispute between modernists and primordialists is not resolved is because it is irresolvable'. ${ }^{1}$ This is because the two approaches place different emphases on different aspects of identity formation. Nairn described the so-called 'Warwick debate', between Anthony Smith and Ernest Gellner, as a 'courteous difference of emphasis'. ${ }^{2}$ He insisted that the debate provided an inadequate set of approaches to the problem of nation formation and that there appeared to be little prospect of progress. Hence, 'the old presuppositions of modernism are losing their hold; but no one is quite sure what new ones will replace them'. ${ }^{3}$ The 'great debate' in nationalism studies, captured at Warwick, is one between so-called 'primordialists' and 'modernists'. Put simply, primordialists argue that the nation derives directly from a priori ethnic groups and is based on kinship ties and ancient heritage. For their part, modernists insist that the nation is an entirely novel form of identity and political organisation, which owes nothing to ethnic heritage and everything to the modern dynamics of industrial capitalism. This chapter provides a brief overview of the two positions but concludes that primordialism and modernism, and the scope of the debate between them, fail to offer a satisfactory account of the formation of national identity.

\section{Primordialist approaches to national identity}

The intellectual link that joins primordialists is the assertion that there was a 'pre-nationalist' period in which political, economic and cultural relationships were not well enough defined, regulated or homogenised to be conducive to the formation of national identity. Primordialists claim that the nation was not therefore 'imagined' or constructed outside prior forms of social community and neither was it a revolutionary or completely novel product of the march 
towards modernity. Instead, they argue that national identity is based directly on previous forms of group identity and draws upon the myths, languages and social practices of these pre-national groups.

Edward Shils and Clifford Geertz are often cited as the 'fathers' of the primordialist school, though primrodialist thinking can be traced back to Herder, Rousseau, and Weber. Shils and Geertz argued that ethnic groups were the direct antecedents of nations. Edward Shils suggested that modern society is held together by an infinity of personal attachments, moral obligations in concrete contexts, professional and creative pride, individual ambition, primordial affinities and a civil sense which is low in many, high in some, and moderate in most persons'. Shils focused on immediate family groups and tried to understand how primary group ties were bound together into larger structures. ${ }^{5} \mathrm{He}$ argued that large social groups are constituted by face-to-face interaction. From here, they continue to expand through the enlargement and joining together of primary groups to form ethnicities. The nation comes about as a result of the amalgamation of ethnicities, which in turn, therefore, are the amalgamation of family groups. Clifford Geertz shared Shils' perspective to a large extent, arguing that a primordial attachment is one that is based upon social 'givens' such as language, religion, or particular social practices. ${ }^{6}$ Geertz identified six forms of primordial tie which, when present, convert loose social groups into nations. They were: assumed blood ties, race, language, region, religion and custom.

Such approaches claimed parsimony but did so at the expense of accuracy. They drew three criticisms from Anthony Smith. First, Smith asked how are we to know who is genetically related when they are outside our own family? Second, Smith insisted that this simplistic primordialist approach could not account for the way that national identity unites distant strangers. Finally, he argued, they failed to discriminate between social phenomena with differing degrees of power, inclusiveness and complexity, and thus completely disregarded epochal change. ${ }^{?}$

John Armstrong, Adrian Hastings and Joshua Fishman offered alternative primordialist accounts. These writers all rejected the modernist claim that nations were new, novel and revolutionary. ${ }^{8}$ They argued that nations and national identities had existed in diverse times and places before the supposed 'birth of nations' in the eighteenth and nineteenth centuries. Thus they insisted that national identity existed before nationalism rather than being constructed by it as modernists claim. They used historical study to show that pre-modern social groups shared traits associated with national identity such as a vernacular language and social rituals. The main problem with such an approach, however, is that it is tempocentric. That is, such approaches create an illusion 'in which the "naturalized" and "reified" present is extrapolated backwards in time to present all historical systems as "isomorphic"."

Anthony Smith and Walker Connor offered a more sophisticated brand of primordialism. These writers often refer to themselves as 'ethno-symbolists' 
rather than primordialists. Connor insisted that the important point that is often overlooked when studying the nation is that it is not what is that is important but rather what people believe it to $b e .^{10}$ It is important that subjects believe there to be kinship ties between themselves and fellow members of the same nation, and it is this emotional and non-rational belief that makes national identity so important and nationalism such a potent political force.

The idea that national identity is a form of non-rational subjectivity that defies empirical and historical debunking lies at the heart of Connor's work. ${ }^{11}$ He makes the primordialist account of nation formation more sophisticated by asserting that nations do not necessarily have a tangible essence that transcends historical epochs. ${ }^{12}$ Connor used many examples to demonstrate cases where the supposed tangible essences of nations, such as language or religion, have changed, but the nation itself and the communal ties within it have persisted. He argued that nations were held together by a 'sense of kinship', so that the nation should be understood as 'a group of people who feel that they are ancestrally related'. ${ }^{13}$ Although he identifies a direct link between the nation and an a priori social group, the relationship is understood as subjective rather than necessarily actual. ${ }^{14}$

Like Connor, Anthony Smith argued that nations are predicated on an ethnic core, which he labelled ethnie. He concurred with the idea that ethnies were largely subjective social entities. However, Smith attempted to draw limits on the extent to which the ethnie could be understood as being subjective. For instance, in his consideration of Ernest Renan's insight that a nation is 'an everyday plebiscite', he observed that the idea that a nation was wholly subjective could lead to any social group being described as a nation. ${ }^{15}$ The cornerstone of Smith's so-called 'ethno-symbolist' approach is a critique of the modernist approach to national identity formation. ${ }^{16}$ Smith's central argument is that national identity derives from an ethnic core. This core has six characteristics. They are: a collective proper name, a myth of common ancestry, shared historical memories, one or more differentiating elements of common culture, an association with a specific homeland, and a sense of solidarity for significant sectors of the population. ${ }^{17}$ He argued that the most important of these are the ones that refer to a shared historical memory, because ethnies are perpetuated not by lines of physical descent but by a sense of continuity, shared history and common destiny. ${ }^{18}$ For Smith, as for Connor, the durability of the ethnie lies not in the cultural traits of the group but in the sharing of a historical memory that is made all the more potent by being related to a specific territory. The shift from ethnie to nation occurred with the perpetuation of three revolutions administrative, economic, and cultural. The local intelligentsia played a role in mobilising a formerly passive community into a vernacular community that acted as the main focus for the polity. ${ }^{19}$ As such, the nation is understood to be both modern (in that the revolutions generally occurred in the nineteenth and twentieth centuries) and 'deep-rooted' (in that it is predicated upon a prior ethnic core). 
Primordialist accounts of national identity formation therefore tend to take one of three approaches:

- Nations are directly derived from prior social groups, which themselves derive from family groups.

- Nations existed in pre-modern times and are therefore neither recent nor novel.

- Nations are based on a well-rooted subjective belief of a shared history and common destiny.

\section{The limits of primordialism}

The turn towards a greater focus on the subjective nature of national identity by writers such as Connor and Smith saves the primordialist approach from straightforward empirical debunking. Nevertheless, primordialism has been attacked on many grounds. Benedict Anderson observed that it tended to overlook the sharp historical discontinuities, discrepancies and contingencies that lay hidden beneath dominant historical discourses about the continuity of nations.$^{20}$ History, he argued, is not characterised by continuity and progress but by perpetual political struggle. John Breuilly challenged the idea that there was even a subjective relationship between the nation and an a priori ethnic group. He argued that national identity was initially a minority pastime pursued by the intelligentsia and linguists that was ignored by the majority peasantry. ${ }^{21}$ Moreover, he pointed out that national identity is a peculiar and exclusionary form of identity that excludes the possibility of alternative and overlapping identities, which according to Breuilly were a feature of prenational group identities. Within the Holy Roman Empire, for instance, it was possible to be Catholic, German and Austrian without any conflict of identity. ${ }^{22}$ This goes against the focus on the development of a single identity that is at the heart of primordialism. Likewise, far from being historically sensitive, primordialism is based on tempocentrism because it utilises modern conceptions of the nation and tries to find historical justifications for them, applying modern concepts to the very different contexts of the past. ${ }^{23}$

A further set of criticisms focus on Smith and Connor's insistence that the links between nations and prior ethnic groups are subjective. First, neither Smith nor Connor discusses how this subjectivity is formed and maintained. For example, Smith argued that the modernist school is flawed because men and women would surely not be prepared to die for a social construct. He failed to explain, however, why men and women would be willing to die for an (apparently) equally constructed and entirely modern form of subjectivity. Second, primordialist methodology is overtly positivist. The histories of ethnic groups are presumed to be 'out there' waiting to be studied, either to credit or discredit the claims made by nationalists. Is it not rather the case that the 
histories are created by the historian's own beliefs about the past? If the historian looks for nations and national lineages in the historical record, they are likely to be found. Finally, even primordialists who claim that the links between past and present are subjective, tend wherever possible to draw supposed 'actual' direct linkages between ethnic groups and nations.

\section{Modernist approaches}

According to Anthony Smith, the modernist account allows no room for the nation in antiquity, since 'for modernists, nations and nationalisms are the products of the novel conditions of modernity'. ${ }^{24}$ Elie Kedourie coined the defining phrase for modernists when he noted that 'nationalism is a doctrine invented in Europe at the beginning of the nineteenth century'. ${ }^{25}$ Kedourie's work focused on the generation and dissemination of the idea of the nation. For Kedourie, this was a necessary and direct precursor to social groups taking on the characteristics of a nation and behaving as if they were national groups. He argued that the nation came into being once ideas of national identity and enlightened self-determination were brought into public politics by the French Revolution and spread across Europe by Napoleon's army. The mobilisation of national identity represented a sharp break from tribalism and opened up an entirely novel process of social organisation.

The central strength of Kedourie's thesis is that it relates to the history of ideas, tracing the development of the idea of the nation in political philosophy. However, this strength is also a weakness because Kedourie did not reveal precisely how these ideas were mobilised. For example, he failed to explain why the rhetoric of the French Revolution was more about the nation than, for example, economic liberty, and why some ideas were mobilised while others were not. Kedourie has also been criticised for locating the emergence of the nation within a relatively narrow timeframe. Anthony Smith, for instance, argued that Kedourie's account 'omits the much longer period of the gestation of nationalism as language-and-symbolism, and as consciousness-and-aspiration' ${ }^{26}$ Furthermore, Adrian Hastings detected a 'derogatory' approach to nationalism and national identity. According to Hastings, Kedourie tended to 'leave out a central line of meaning and even to misunderstand or denigrate much of what is most valuable in the European cultural and political achievement'. ${ }^{27}$ Finally, Kedourie's approach can be accused of being Eurocentric, a point underscored by his opening assertion that nations were invented in Europe, which ignores the development of national identities in places such as Japan.

Another group of modernists argue that rather than the idea of the nation constituting the possibility of thinking about the modern, bureaucratic and sovereign territorial state, the nation was itself constituted by the emergence of the modern state. For instance, John Breuilly argued that 'nationalism is a form of politics' ${ }^{28} \mathrm{He}$ suggested that nationalist discourses are actually political 
movements through which people seek to attain state power. ${ }^{29}$ For Breuilly, nationalism is meaningless if it is considered in isolation from the state, because the modern state shaped the nationalist agenda and provided it with an overarching objective - the possession of statehood. ${ }^{30}$

The closest Breuilly came to outlining an account of the emergence of a national 'order of things' was a brief discussion of the transfer of political power from monarchs to an enlarged political community. He suggested that the driving force behind this transfer was the need to defend the monarch's territory against the rise of similar states, though this tautology is unconvincing. ${ }^{31} \mathrm{He}$ argued that political necessity dictated that the feudal system be replaced by a system based upon nation-states. As such, the idea of the nation was directly related to the institutions of state that sustained the monarchy. However, the new political community eventually turned the nation against the monarch. So, 'in this way the process which created the modern idea of the state in its earliest form also gave rise to the political concept of the nation' ${ }^{32}$ As the monarchy began to penetrate more and more aspects of social life, the scope for conflict increased and the idea of the nation began to mobilise the masses.

Breuilly's most important insight was that the nation and the political ideology of nationalism were constructed to fulfil the needs of political communities who opposed the expanding role of the monarchy (the emerging middle class). Paul Brass offered a similar account of the emergence of national identity. ${ }^{33}$ Brass viewed national identity as the result of a process whereby elites mobilised aspects of a social group's culture or behaviour and attached new meanings to them. ${ }^{34}$ They then used them as symbols to mobilise the group, defend its interests and compete with other groups. For Breuilly and Brass, therefore, the process of national identity formation should be seen as an inherently political one.

The most consistently state-centric of the thinkers who insist that the emergence of the nation was a direct consequence of the emergence of the bureaucratic state is Anthony Giddens. Giddens based his analysis on Max Weber's notion that it is not possible to speak of the 'nation' as distinct from the state because the two are necessary cohabitants in the political and social organisations produced by modernity. ${ }^{35}$ Contrasting the nation-state with other polities, Giddens argued that the contemporary state attempts to construct a bordered homogeneity over its territory, which it is able to do by utilising the extensive bureaucratic power that came with the industrial advances of early modernity. He traced the emergence of the nation-state to three developments, each related to the military. These were the technological development of armaments, the amplification of military administrative power and the importance of naval power in interconnecting the world. ${ }^{36}$ Giddens suggested that the nation emerged out of the centralisation of bureaucratic power by the modern state, which produced a homogenous education system, economic system and social rituals, naturalising vernacular languages and producing forms of high culture that legitimised the bureaucratic state and allowed it to function efficiently. ${ }^{37}$ 
Paul James made two criticisms of Giddens' approach, which could be extended to the other modernists who focus on the role of the state. ${ }^{38}$ First, he argued that this approach is both Eurocentric and historically contentious. According to James, Giddens repeatedly argued that the increasing political salience of national identity was caused by the administrative power of the absolutist European state. However, James pointed to the example of Tokinawa's Japan, which exerted a high level of administrative control within a clearly bordered entity prior to such developments in Europe. Second, he argued that this account of national identity formation is too restrictive. It reduces the nation to the product of a particular structure of political and military power. An additional problem with Breuilly, Brass and (to a lesser extent) Giddens is that they each failed to account for the changes in political or bureaucratic power upon which, they claimed, the nation was predicated. A major tautological claim is used to explain the emergence and spread of the modern state (the modern state developed because other modern states were developing).

A final group of modernist thinkers agree that the rise of the nation was interdependent with the rise of the modern state. However, they account for these political and social changes by reference to the social and economic demands created by the industrial revolution. Benedict Anderson's pioneering work showed how the nation came to be 'imagined' and the strong ties of sentimentality that were generated by this imagination. He began by arguing that national identities emerged as a result of complex social interactions with varying degrees of 'self-consciousness' ${ }^{39}$ Anderson understood the nation as an imagined community, because 'the members of even the smallest nation will never know most of their fellow members ... yet in the minds of each lives the image of their communion'. ${ }^{40}$ To say that the nation is imagined is not to say that it is 'false', 'fabricated' or 'invented'. Rather, it is imagined in three ways. First, it is imagined as limited because all nations have limits and none aspires to incorporate mankind. Second, because the concept of the nation emerged during the Enlightenment, the nation is imagined as being sovereign. Finally, the nation is imagined as being a community able to command the highest levels of commitment across the boundaries of socio-economic class. Not surprisingly, Anderson's thesis has been criticised by Anthony Smith. ${ }^{41}$ For Smith, Anderson's focus on literary texts, which emerged from his interest in print-capitalism, meant that his thesis lacked a solid historiographical grounding and failed to account for how particular nations emerged in specific times and places.

Within the same tradition of enquiry, the social and economic historian Eric Hobsbawm offered an account of national identity formation, which held that "the nation was one of many traditions "invented" by political elites in order to legitimise their power in a century of revolution and democratisation'. ${ }^{42}$ By an 'invented tradition' Hobsbawm meant:

A set of practices, normally governed by overtly or tacitly accepted rules and of a ritual or symbolic nature, which seek to inculcate certain values and norms of behaviour by repetition, which automatically implies continuity with the past. In 
fact, where possible, they normally attempt to establish continuity with a suitable historic past. $^{43}$

Hobsbawm's 'invented traditions' are therefore considerably different from Anderson's 'imagined communities'. Whereas Anderson was often at pains to point out that to imagine is not necessarily to fabricate, Hobsbawm insisted that an invented tradition 'is largely fictitious'. ${ }^{44}$ Such traditions attempt to legitimise themselves by appearing to be historically continuous and 'ancient', when in fact they are anything but. As Hobsbawm pointed out in a rebuke to the primordialists, 'novelty is no less novel for being able to dress up easily as antiquity'. ${ }^{45}$ The nation should therefore be seen as an invented tradition that emerged as a response to the upheavals caused by modernity and the industrial revolution. ${ }^{46}$

Hobsbawm began his account by identifying the problems encountered by objective and subjective accounts. Objective accounts, which claim that a nation is constituted by the existence of certain objective elements such as shared language or shared cultural practices, are problematic because 'only some members of the large class of entities which fit such definitions can at any time be described as "nations". ${ }^{47}$ On the other hand, subjective accounts, which define nations by their members' self-consciousness, are tautological according to Hobsbawm. They could lead us to believe that any entity claiming to be a nation could become one. As such, Hobsbawm insisted that both objective and subjective accounts were potentially misleading. Following Ernest Gellner, he argued that national identity and nationalism are inherently political terms and that the nation is constructed through nationalism, rather than the other way round. ${ }^{48}$ Alongside Anderson, Hobsbawm argued that the development of industrial modes of communication (print-capitalism) made thinking about the nation a viable popular activity, and from his own historical writings he noted that it was impossible to speak of the nation outside the historical context in which it emerged. All this meant that, for Hobsbawm, the key feature of the nation was its modernity.

Hobsbawm argued that the principal factor driving the march towards a 'national order of things' was the imperative of economic transformation. ${ }^{49}$ Intellectuals in the nineteenth century and earlier extolled the virtues of large states, and the idea of the nation came to be tied to the general expansion of social groups that was necessitated by the technological transformations of that period. ${ }^{50}$ However, the main problem that confronted Hobsbawm was that, because he describes the nation as a fabrication, it is very difficult (if not impossible) for him to explain why it is that the nation took such a hold on the modern political imagination of the common people.

Ernest Gellner attempted to address this problem by offering a more sophisticated and all-encompassing account of the emergence of the nation. For Gellner, the nation is an idea that underpins the modern social imagination to the extent that it is not possible to think of individuals existing outside the 
nation without strongly challenging the modern imagination. ${ }^{51}$ This is not an inherent attribute of humanity. Rather, it is a contingency derived from the socio-political demands of the industrial revolution. However, this contingency presents itself as 'natural' or 'obvious', establishing what others may call a reified 'national order of things'.

Whereas for Kedourie the idea of the nation promoted homogenisation, for Gellner 'a homogeneity imposed by objective, inescapable imperatives [those of modern industrial society] eventually appears on the surface in the form of nationalism'.$^{52} \mathrm{He}$ argued that there were five stages of nationalism, the first three of which accounted for the shift from pre-national social organisation to the reification of the 'national order of things'. The first stage was the dissolution of the medieval system and the replacement of the universal eschatological order with a structure comprised of sovereign states, though in this early stage there was no national relationship between ruler and ruled. ${ }^{53}$ During the second stage, the functions of the state began to shift, with two new imperatives coming to form an international moral order. The first imperative was the solidification of the sovereign state. The second was the emerging ideas of the Enlightenment, whereby the 'people' came to be seen as the ultimate repository of moral authority. The third epoch saw the idea and practice of the 'nation' spread from intellectual and political elites to the lower classes. This process was a direct result of the urbanisation, spread of universal education and capitalist division of labour that were made necessary by the industrial revolution. The demands for occupational mobility and the increased technical sophistication of methods of production required the use of common languages, codes and symbols.

The economic imperative was what led Gellner to argue that the nation did not create social homogeneity but that instead it itself evolved from largely economic demands for social homogeneity. Gellner emphasised the idea that the nation and the modern state developed as responses to economic change. ${ }^{54}$ Viewed this way, the nation must be seen as a consequence of the social ordering made necessary by the industrial revolution. This social order was legitimised by what Gellner described as the predominance of 'high cultures'.

Gellner's discussion of 'high cultures' was important because it offered an explanation of how the nation came to establish its own 'order of things'. The nation was constituted by both the will of the people and the dissemination of 'high culture' throughout the whole of society. In the pre-modern period, 'high culture' was only accessible through certain mediums that were generally only available to social elites. With the construction of the nation, 'high culture' began to pervade entire societies via vernacular languages and histories that were accessed through new forms of education. The nation was formed through the 'fusion of will, culture and polity', a fusion necessitated by the advent of industrialism. ${ }^{55}$

Although Gellner offered a more sophisticated and multi-layered account than Anderson and Hobsbawm who were tied to an essentially Marxist outlook, several points of criticism have been made. First, Paul James argued that 
Gellner's discussion of pre-agrarian society produced an 'ethnocentric, elitist, teleological, functionalist, idealist version of the great divide. ${ }^{56}$ Second, Hobsbawm argued that Gellner's analysis was inherently elite-centric and 'top-down'.57 Third, although theoretically appealing, Gellner's long historical sweep made many parts of the study empirically problematic. For example, Miroslav Hroch has created problems for the whole modernist school because he has convincingly argued that ideas about the nation and practices of nationalism actually emerged in areas where industrialisation and modernisation were not taking hold. ${ }^{58}$

\section{Beyond the 'great divide'}

Primordialists argue that the nation is predicated on either actual ties or a subjective belief in an a priori ethnic community. Modernists, however, insist that the nation is an entirely novel form of social organisation, constructed during the dramatic social transformations of the industrial revolution. Both approaches offer unsatisfactory accounts. Primordialism fails to account for the ways that nations arose within the wider sociological, religious, political and economic transformations that accompanied the advent of industrialism and modernity. It can also be criticised on empirical grounds because there are very few direct historical connections between the ethnie and the nation. Primordialists are only able to sustain their argument because they employ a problematic teleological and tempocentric historiography. Their approach to history emphasises continuity over change and tends to overlook the radical transformations that characterised the early modern period. They also tend to take contemporary ideas about social formation and look for them in antiquity. Finally, primordialists do not adequately address the question of how local identities are transcribed on to the macro-level to form nations or why nations and nationalism became the dominant mode of social organisation when they did.

The modernist side of the 'great divide' is also problematic. The argument that national identity is entirely novel means that modernists need to amplify the extent to which the national order of things is unprecedented. This, however, leads them towards a teleological account as well, because they need to account for why national identity as opposed to other forms of identity (such as class) became predominant. Moreover, modernists fail to address the question of how it was that something modern, socially constructed and - some argue fabricated was able to constitute the limit of political imagination to the extent that the nation has done in modern times. This is particularly problematic given that most modernists tend to place the emergence of nations within a short timeframe of a century or so. Finally, modernism also employs shaky historiography. It is decidedly ethnocentric, ignoring pre-national Asian 'nationalisms' and the agrarian nationalism of non-industrial states.

The central problem with accounts that emerge from the 'great divide' is 
that they are mutually exclusive. Primordialists retain a degree of objectivity in their 'nation', while for modernists the nation is wholly subjective. Primordialists emphasise the role of continuity-over-change in history, while modernists insist that history is better characterised as change-over-continuity. Neither of these polemics offers an account that appreciates the complexities, discrepancies and peculiarities of nation formation. It is because of this problem that recent literature on the question has tended to move away from this debate and offer accounts that are more nuanced and specific. The following chapter therefore begins by considering alternative ways of thinking about the formation of national identity that do not follow the terms of the 'great debate'. It is from this literature, I argue, that a useful framework for understanding the formation of Croatian national identity in the 1990 s can be developed.

\section{Notes}

1 T. Nairn, Faces of Nationalism: Janus Revisited (London: Verso, 1997), p. 11.

2 Nairn, Faces of Nationalism, p. 11. The Warwick debate was held at Warwick University on 24 October 1995. See A. D. Smith, 'Opening statement: nations and their pasts', Nations and Nationalism, 2:3 (1996); E. Gellner, 'Reply: do nations have navels?', Nations and Nationalism, 2:3 (1996); and A. D. Smith, 'Memory and modernity: reflections on E. Gellner's theory of nationalism', Nations and Nationalism, 2:3 (1996).

3 Nairn, Faces of Nationalism, p. 11.

4 E. Shils, 'Primordial, personal, sacred and civil ties', British Journal of Sociology, 8 (1957), 131.

5 Shils, 'Primordial, personal', 133.

6 C. Geertz, 'The integrative revolution: primordial sentiments and civil politics in the new states', in C. Geertz (ed.), Old Societies and New States: The Quest for Modernity in Africa and Asia (New York: Free Press, 1963), pp. 109-11.

7 A. D. Smith, Nationalism and Modernism (London: Routledge, 1998), pp. 147-50.

8 See J. Armstrong, Nations Before Nationalism (Chapel Hill: University of North Carolina Press, 1982); J. Fishman, Language and Nationalism: Two Integrative Essays (Rowley MA: Newbury House, 1972); and A. Hastings, The Construction of Nationhood (Cambridge: Cambridge University Press, 1997).

9 J. M. Hobson, 'What's at stake in bringing historical sociology back into international relations? Transcending chronofetishism and tempocentism in international relations', in S. Hobden and J. M. Hobson (eds), Historical Sociology of International Relations (Cambridge: Cambridge University Press, 2002), p. 7.

10 W. Connor, 'A nation is a nation, is a state, is an ethnic group, is a ...', Ethnic and Racial Studies, 1:1 (1978), 377-400.

11 W. Connor, Ethnonationalism: The Quest for Understanding (Princeton NJ: Princeton University Press, 1994).

12 Connor, Ethnonationalism, p. 197.

13 Connor, Ethnonationalism, p. 202.

14 See W. Connor, 'The politics of ethnonationalism', Journal of International Affairs, 27:1 (1973), 1-21.

15 E. Renan, Qu'est-ce qu'une Nation? (Paris: Calmann-Levy, 1882), p. 17.

16 See in particular A. D. Smith, Theories of Nationalism (London: Duckworth, 1971) and A. D. Smith, 'National Identities: Modern and Medieval?', in S. Forde, L. Johnson and 
A. V. Murray (eds), Concepts of National Identity in the Middle Ages (Leeds: Leeds Texts and Monographs, 1995).

17 A. D. Smith, National Identity (Harmondsworth: Penguin, 1991), p. 21.

18 Smith, National Identity, p. 29.

19 These arguments, though appearing in National Identity first appeared in A. D. Smith, The Ethnic Revival in the Modern World (Cambridge, University Press, 1981), pp. 15473.

20 B. Anderson, Imagined Communities (London: Verso, revised edition, 1983), p. 9.

21 J. Breuilly, Nationalism and the State (Manchester: Manchester University Press, 1982), p. 19.

22 Breuilly, Nationalism, p. 20.

23 J. Hutchinson, Modern Nationalism (London: Fontana, 1994), pp. 6-7.

24 Hutchinson, Modern Nationalism, p. 22.

25 E. Kedourie, Nationalism (Oxford: Basil Blackwell, 4th edition, 1993), p. 1.

26 Smith, National Identity, p. 85.

27 Hastings, The Construction of Nationhood, p. 12.

28 Breuilly, Nationalism, p. 1.

29 Breuilly, Nationalism, p. 3.

30 See Breuilly's conclusion and Nationalism, p. 352.

31 Breuilly, Nationalism, p. 359.

32 Breuilly, Nationalism, p. 359.

33 J. Hutchinson and A. Smith (eds), Nationalism (Oxford: Oxford University Press, 1994), p. 48.

34 P. Brass, Ethnicity and Nationalism: Theory and Comparison (London: Sage, 1991), p. 105.

35 See A. Giddens, The Nation-State and Violence: A Contemporary Critique of Historical Materialism, volume 2 (Cambridge: Polity Press, 1985); A. Giddens, 'Nation states and violence', in A. Giddens, Social Theory and Modern Sociology (Cambridge: Polity Press, 1987); and A. Giddens, Modernity and Self Identity (Cambridge: Polity Press, 1991). For an indication of his wider thesis see A. Giddens, The Constitution of Modernity (Cambridge: Polity Press, 1984).

36 Giddens, The Nation-State and Violence, pp. 105-16.

37 Giddens, The Nation-State and Violence, p. 112.

38 P. James, Nation Formation: Towards a Theory of Abstract Community (London: Sage, 1997), pp. 157-61.

39 Anderson, Imagined Communities, p. 4.

40 Anderson, Imagined Communities, p. 6.

41 A. D. Smith, 'The nation: invented, imagined, reconstructed?', Millennium: Journal of International Studies, 20:3 (1991), 353-68.

42 Hutchinson and Smith, Nationalism, p. 48.

43 E. Hobsbawm, 'Introduction: inventing traditions', in E. Hobsbawm and T. Ranger (eds), The Invention of Tradition (Cambridge: Cambridge University Press, 1983), p. 1.

44 Hobsbawm, 'Introduction', p. 2.

45 Hobsbawm, 'Introduction', p. 5.

46 E. Hobsbawm, The Age of Capital: 1848-1875 (London: Weidenfeld and Nicolson, 1975), p. 84.

47 E. Hobsbawm, Nations and Nationalism Since 1780: Programme, Myth, Reality (Cambridge: Cambridge University Press, 1990), p. 6.

48 Hobsbawm, Nations and Nationalism, p. 9. See also E. Hobsbawm, 'The limits of nationalism', New Society (2 October 1969), p. 523 and E. Hobsbawm, 'Some reflections on nationalism', in T. J. Nossiter, A. H. Hanson and S. Rokkan (eds), Imagination and Precision in the Social Sciences (London: Faber and Faber, 1972). 
49 See Chapter 6 of E. Hobsbawm, The Age of Empire: 1874-1914 (London: Weidenfeld and Nicolson, 1987).

50 Hobsbawm, 'The limits of nationalism', pp. 31-3.

51 E. Gellner, Nations and Nationalism (Oxford: Basil Blackwell, 1983), p. 5. Also see J. A. Hall (ed.), The State of the Nation: Ernest Gellner and the Theory of Nationalism (Cambridge: Cambridge University Press, 1998).

52 Gellner, Nations and Nationalism, p. 39.

53 Gellner, Encounters with Nationalism, p. 23.

54 Gellner, Nations and Nationalism, p. 46.

55 Gellner, Nations and Nationalism, p. 55.

56 James, Nation Formation, p. 132.

57 Hobsbawm, Nations and Nationalism, p. 11.

58 M. Hroch, 'From national movement to fully formed nation', New Left Review, 198 (1993), 3-20. 


\section{2 \\ Re-imagining the nation}

Some years before the 'Warwick debate', the journal Millennium held a symposium entitled 're-imagining the nation'.' In his introduction to the volume, Adam Lerner suggested that ' $[t]$ he nation exists as much in people's minds as it does in the world'. ${ }^{2}$ By this, he seemed to be suggesting that the nation could be viewed as real and constructed, primordial and modern. The contributors to this collection agreed that the 'great divide' offered unsatisfactory ways of understanding the formation of national identity and shared a desire to 're-imagine' the nation in ways that could build on the insights offered by both sides of the divide. This chapter considers some of these new approaches to the study of national identity formation and assesses how they can be used to study the formation of Croatian national identity in the 1990s.

\section{New approaches to national identity formation}

Reflecting the growing dissatisfaction with earlier approaches to national identity, Liisa Mallki, Michael Billig, Sarah Radcliffe and Sally Westwood have offered alternative ways of thinking about nation formation that expose how nations are continually produced and reproduced in human subjectivity. These works reveal that the nation operates in ways that are often 'unseen' by grand theories that tend to see nation formation as a process that culminates with the creation of nation-state rather than as an on-going project that is reproduced on a daily basis.

Liisa Malkki's 'ethnography of displacement in the national order of things' is interesting because it combined a modernist view of the social world with an approach that emphasises the importance of historical memory. ${ }^{3}$ As Malkki explained, 'the construction of a national past is a construction of history of a particular kind; it is one that claims moral attachments to specific territories, 
motherlands or homelands, and posits time-honored links between people, polity and territory'. ${ }^{4}$ Much of Malkki's study is concerned with the experiences of refugees in Tanzania and how two groups in particular mediated their problematic position in the 'national order of things'. By referring to the 'national order of things', Malkki suggested that something that is quite recent (the idea that human polities should be organised according to national taxonomies) has been reified to the extent that it appears natural and ancient. Malkki viewed the nation as the floor of a Foucauldian 'regime of truth'. She noted that the nation acts as 'a powerful regime of classification', an 'apparently commonsensical system of ordering and sorting people into national kinds and types'. ${ }^{5}$ For Malkki, the nation operates as an absolute differentiator, which makes certain collusions of people and territory appear natural and others incommensurable. ${ }^{6}$

Malkki offered an interesting new insight into the nature of the nation's historical memory. Rather than seeing it as an emancipatory mode of social action, Malkki argued that the historical memory of the nation operates in such a way as to constrain social action by locating particularist and absolute identities within particular and absolute social and spatial locations. ${ }^{7}$ The rest of Malkki's argument, which forms the backbone of her work, is an explanation of how these narratives ('mythico-histories') are articulated as a response to particular sets of social circumstances and reproduced on a daily basis to produce certain meanings on which people base their actions. ${ }^{8}$

In similar vein, Michael Billig's study of 'banal nationalism' considered how the nation is produced and reproduced by daily social practices. ${ }^{9}$ His opening contention is that nationalism and the active reproduction of national identity occurs constantly within all nation-states. His study focused on the ways that polities are reproduced as national and their citizens as nationals. ${ }^{10}$ Billig sees nationalism as being far from an intermittent mood in established nations or something exotic that exists on the periphery. Instead, it is 'the endemic condition'. ${ }^{11}$ His central question is, 'why do people not forget their nationality?' He attempted to answer this question by insisting that ' $\mathrm{I}] \mathrm{n}$ established nations there is a continual "flagging"/"reminding" of nationhood. Nationhood provides a continual background for political discourse, for cultural products and even the structuring of newspapers'. ${ }^{12}$ Moreover, Billig identified the ways in which political discourse assumes the existence of a 'national' audience.

Billig argued that much of the 'flagging' of the nation occurs in ways that go unseen because the process of being reminded is so familiar. This constant reminding is situated in the so-called 'habits of social life', which include processes of thought and communication. ${ }^{13}$ The concept of banal nationalism is exemplified by the difference between the waved and the unwaved flag. The 'unwaved flag' is so deeply embedded in subjective consciousness that it is both seen and unseen. It goes unnoticed because it is so familiar. However, it remains as important as the memorable activities of flag waving. Thus Billig focused on 
the mundane, taken-for-granted, day-to-day and forgotten level of social practice where ideas of national identity are given material resonance.

Billig suggested that it is inappropriate to consider national identity as merely one identity among many. Instead, he argued that it operates as a kind of 'ideological consciousness' that constitutes nations, national identities and homelands, and reifies them in such a way as to make them appear 'natural and ancient'. ${ }^{14}$ This assertion, and the similar one made by Malkki, raised an obvious objection from Anthony Smith. That is, how can the nation become reified and operate as a powerful regime of truth if its ethnic heritage is denied? Malkki's study located these processes of reification within the specific social setting of 'refugeeness' in Tanzania, and did not draw general conclusions about the reification of the nation and its 'order of things'. Billig, however, did draw general insights, arguing that the practice of imagining the nation 'must be habitual or unimaginatively accomplished'. ${ }^{15}$ The process of imagining the nation is not seen as one that exists externally to subjectivity or one that occurs only in the process of forming the nation. Instead, it is something that is constantly reproduced in all forms of social discourse on a daily basis and local level. To support these claims, Billig detailed the ways in which assumptions about the nation underlay popular, political and bureaucratic discourses to reveal that 'notions of nationhood are deeply embedded in contemporary ways of thinking'. ${ }^{16}$

Billig called for students of national identity to 'look and see the constant flaggings of nationhood ... often unnoticed, these flaggings are not hidden'. ${ }^{17}$ These flaggings do not exist in the grand narratives of intellectuals. Instead, they reify the nation exactly because they operate within the local, day-to-day experiences of people. However, Billig does not explain whether the constant flagging of the nation is a conscious or subconscious activity. If it is a conscious activity, then he needs to explain which social groups do the flagging, why, and how it becomes reified in the imaginations of the (presumably) non-national masses. If it is a subconscious process, Billig again has to suggest reasons why the flagging takes place and how it becomes embedded in the popular imagination. Also, Billig does not explain how national identity came to be such a fundamental form of identity that often appears to transcend local identities.

Sarah Radcliffe and Sally Westwood addressed the problem of the relationship between the 'big stories' of national identity and the 'small stories' through which the nation is made apparent in local situations. ${ }^{18}$ They argued that the process of nation formation has four components: imagining the nation, embodying the nation, living in the nation and placing the nation. Only once these four aspects are in place is it possible to reify the nation in the lived experiences of individual subjects.

Radcliffe and Westwood argued that in newly forming nations the national imagining 'is the result of complex relationships between representations, subjects, the media and identity'. ${ }^{19}$ Recalling Benedict Anderson's focus on 'print-capitalism', they argued that in some situations literature can offer a 
'gallery of representations' that provides the nation with a history and geography. The general relates to the local in the way that (national) representations come to be seen as common sense and enable the individual subject to be located within a general schema of history and geography. This relationship is not one-way, however. Instead, it can be understood as dialectic, as these subjective interpretations of the nation are in turn transmitted from the particular back to the general. What is important is that abstract ideas of national identity are 'internalised' in the day-to-day practices of subjects. It is in this way that nations are given physical shape, though conversely it is also through these processes that the meanings of national identity are constantly challenged and reinterpreted.

The embodying of the nation is the process of reifying and substantiating the idea of the nation within the imagination of individual subjects. Radcliffe and Westwood noted that most studies of national identity locate this process within the modern bureaucratic state because, '[A]s a modern regime of power, the state utilizes a series of mechanisms of normalization that come to rest on the body and through which power relations are produced and channeled. Individual subjects are then constituted in and through the relations of power and the discourses produced by it. ${ }^{30}$ The state comes to be seen as the embodiment of the imagined nation in such a way that the technologies of power it utilises actually creates national subjectivity at the local level. Departing from Malkki and Billig, Radcliffe and Westwood argued that bureaucratic attempts to 'fix' subjective national identities come up against competing forms of experiences and identity and that in the locale there are 'cross-cutting identities' that succeed in subverting the national imagination. ${ }^{21}$ This suggests that studies of national identity formation should consider the 'multi-dimensional agency and self-consciousness' of subjects. ${ }^{22}$ The importance of the small story of the nation emerges because 'a nation is thus a component in each individual's selfand other- awareness'. ${ }^{23}$ The nation comes to mean many things, depending on how national imagery and discourses are translated, the other forms of identity with which it intersects, and the social settings in which these processes take place.

Building on this idea, Radcliffe and Westwood suggested that the 'living nation' should be seen as a wide and multi-dimensional category, since 'national identities can mean different things to different people even within the same nation'. ${ }^{24}$ They raised the question of what constitutes the nation and suggested that it is essentially a relationship between a people and a territory, though the exact nature of that relationship is open to interpretation. ${ }^{25}$ Finally, therefore, the question of place and nation is raised. The people-place nexus permits the drawing of the national limit (the sovereign nation) that is so important to Benedict Anderson's theory. Furthermore, this nexus enables the transition of the nation from the discursive to the material in local and specific circumstances. Thus, 'everyday practices produce and reproduce national identities in a variety of sites from the home and neighbourhood to the workplace and 
public sphere. Rather than being merely narrations, national identities and nations are embedded in the material and imaginative spatialities of collective and individual subjects. ${ }^{26}$

This quote neatly summarises these new approaches to national identity formation. National identity is not about ancient ethnic re-awakening or the construction of grand narratives of nationalism designed to suit the instrumental needs of capital. Instead, it should be seen as a complex relationship between different factors that are manifested at a local level and impact upon individual subjects. In these new approaches to national identity formation, the nation is viewed as constantly reproduced, 'flagged' and translated in ways that often go unseen.

There is therefore a growing disquiet with approaches that emerge from the 'great divide'. There is a widespread view that general theories of nation formation tell us little about specific cases because of their generality. As David McCrone pointed out, this means that, 'no single universal theory of nationalism is possible', because, 'as the historical record is so diverse, so too must be our concepts. ${ }^{27}$ There is also a widespread view that primordialism and modernism are historically naive because neither fully appreciates the extent to which continuity and discontinuity overlap. There is therefore a substantial middle ground between these two positions that has been identified by recent literature. To say, as Smith does, that nations emerged from prior ethnies is not necessarily to deny the importance of the transformative changes of modernity. Likewise, to argue that a nation is a socially constructed product of modernity is not necessarily to argue that it is an 'invented tradition' that marks a sharp break from the past. Finally, there is a concern that approaches to nationalism and national identity operate at too high a level of abstraction and thus fail to account for the nation as an integral part of the local, day-to-day, material experiences of people. The pertinence of national identity in the modern social imagination can only be accounted for by locating it at the nexus of the abstract and the everyday.

The approaches spawned by this disquiet reveal broader ways of understanding nation formation. What becomes apparent is that there is no one particular account of nationalism and national identity that either explains specific instances or helps us understand the phenomenon of nation-ness itself. Instead, as David McCrone and Paul James pointed out, the nation is constituted at the intersection of many competing discourses and material factors. The nation is not perpetuated at levels of high social abstraction, but in the ways that 'big stories' are manifested in the meanings given to local, particular and contingent actions that occur at the day-to-day level. This view of the nation is altogether more complex than the other accounts, and the contradictions within these 're-imagined' accounts only serve to highlight the contradictions in national identity itself. 


\section{Towards a theory of abstract community}

Paul James has carried out perhaps the most substantive 're-imagining' of the nation in the recent times. ${ }^{28} \mathrm{He}$ attempted to overcome the 'great divide' by insisting that primordialist and modernist accounts could be synthesised. Underlying his consideration of writers from Marx and Weber, to Gellner and Giddens is the view that 'nation-states in general depend for their nationalized, concrete awesomeness upon intersecting levels of integration, framed by the most abstract level but never in a way that can resolve the contradictions of that intersection'. ${ }^{29}$

James sees the formation of national identity as resulting from a number of intersections at different levels. He argued that traditional approaches to nation formation are guilty of 'treating social life as if it were constituted on one plane'..$^{30}$ He uses this idea to claim that other theories of national identity formation reduce complex processes of social formation to a single dominant ontology. The result of such ontological reductionism is that:

There may still be recognition by those same theorists that social life is conducted along different time-space extensions, from face-to-face interactions to more disembodied interactions mediated through the electronic media, but the actuality of constitutively different human natures formed across different societies, and the possibility of contradictory subjectivities formed within the same society or the same person, are often either disregarded or relegated to the realm of psychoanalysis. $^{31}$

Thus, accounts that emerge from the 'great divide' operate at only one of many possible levels. Furthermore, they negate the very possibility of talking about ontological plurality by constructing such rigid theoretical schema.

James argued that the 'great divide' debate ought to be treated as a problem in itself by students of nation formation. The problem is one of understanding the emergence of nationality as the central focus of political organisation and imagination without awarding ontological priority to its historiography. It is important to avoid ontological prioritisation because although modernism has successfully exposed the weaknesses of primordialism, this has led to a tendency to lose sight 'of the way in which social forms constitutive of the nation have long-run continuities such as are exemplified in the medieval natio'. ${ }^{32}$ For example, in criticising Nairn, Gellner and Giddens, James argued that they failed to appreciate that prior to the nation-state there were 'materially grounded subjectivities', which were able to take on the functions of an 'imagined community' by providing connections between strangers. ${ }^{33}$ James suggested that historical or literary research reveals occasions of imagined attachment prior to the advent of nations to a greater extent than modernists are willing to admit. ${ }^{34}$

Paul James introduced two new concepts to the study of nationalism and national identity. The first is the concept of 'continuity-in-discontinuity'. According to James, this idea represents an attempt to find a 'third way' 
between primordialism and modernism. It distinguishes between levels of continuity and discontinuity and thus avoids the perception that they must be mutually exclusive. Continuity-in-discontinuity is supported by the view that there is no single ontology of the nation but rather that the nation is constituted at a number of levels of abstraction. At the most material, or locale, level it is possible to see a great deal of discontinuity, dislocation and change in the meanings given to the political community. Viewing national identity formation from this level, the dominant theme appears to be that of constant change. However, using another more abstract ontology makes it possible to 'see' historical continuities in processes of social formation. ${ }^{35}$ The relationship between the different levels of abstraction and continuity-in-discontinuity is understood by James as being one in which 'both communities, drawing upon practices constituted at a disembodied level of abstraction, "call upon" less abstract levels to give their association a depth of meaning. Both communities connect strangers in terms of affiliations expressed through a continuing but subordinate level of face-to-face integration. ${ }^{36}$

Within imagined communities there are simultaneous social processes that are both continuous and changing, depending upon the level of abstraction used. The greater the level of abstraction, the more the picture is one of continuity-over-change. For James, the nation is constituted at the most abstract level but is constantly reproduced, represented and reinterpreted at the most local level in ways that cause cross-level contradictions. Other approaches to national identity formation have attempted to reconcile these contradictions by awarding ontological priority to one of the levels, causing the problems outlined above. James argued that it is not necessary to reconcile these contradictions. Instead, locating and understanding the contradictions is an essential part of the study of national identity formation.

The idea that the nation results from a variety of social contradictions is expressed in the oxymoronic concept of 'abstract community'. According to James, 'the nation is an abstract community which only becomes possible within a social formation constituted through the emerging dominance of relations of disembodied extension'. ${ }^{37} \mathrm{He}$ moves from 'imagination' to 'abstraction' in order to emphasise that the processes he is describing are both material and ideational, unlike Anderson's 'imagined communities' which are essentially constituted in the realm of ideas. The oxymoron is completed with 'community', implying 'direct relations of mutuality', something which in turn implies spatial presence in contradiction to the processes of abstraction that seek to move away from such presence. ${ }^{38}$ James deliberately married 'abstract' and 'community' in order to emphasise the contradictions of 'continuity-in-discontinuity' and the ways that subjectivity both constitutes and is constituted by the abstract, and therefore the way in which identities can appear to persist or change depending on the ontology employed to study them.

Paul James explicitly argued that his insights do not constitute a new research agenda for the study of national identity formation. Indeed, he argued 
that he should consider writing a second volume that is more richly historical in nature..$^{39}$ Although he raised many themes that enable us to move beyond the 'great divide', he did not suggest how these themes can be operationalised. If we are to use James' account of the formation of abstract communities to study contemporary Croatian national identity, it is necessary therefore to elaborate on these themes. For this, we need the work of Katherine Verdery.

Verdery accepted many of James' insights, such as the problematisation of the 'great divide', and offers a series of research questions that combine the themes of continuity and change that are embedded in James' work. All too often, Verdery suggested, national identity is reified so that it appears no longer to interact, compete, mould and be moulded by other forms of identity and different social settings. ${ }^{40}$ Furthermore, even after the complex processes of its formation, the nation continues to exist at more than one ontological level. Verdery pointed out that 'nations, like individuals, are thought to have identities, often based in so-called national characters. National identity thus exists at two levels: the individual's sense of self as national, and the identity of the collective whole in relation to others of the kind. ${ }^{31}$ Verdery outlined three ways in which previous accounts of national identity formation were fundamentally flawed before briefly suggesting a series of research questions that can overcome the problems and incorporate the ontological pluralism envisaged by James. The first problem is that students of national identity should 'explore which sense of nation is apt to the context in question, rather than imposing a modern sense on a medieval reality'. ${ }^{2}$ Second, a study of national identity should appreciate that the nation can have multiple meanings. These divergences of meaning occur not only when different social ontologies are employed but also when the processes through which abstract ideas are internalised in the material experiences of individual subjects. The third pitfall is that the nation should be seen as both an ontological and epistemological problem. Verdery argued that scholars who are interested in national identity should not 'treat nations as actually defined, for example, by culture, or descent, or history'. ${ }^{43}$ Instead, the student should constantly question what function these terms are fulfilling and in what context they are operating.

Verdery built upon these general criticisms to pose five questions that can be used to inform a study of national identity formation. These are:

- What underlies the notion of identity?

- How do people become national?

- How variously is the nation symbolised?

- How can we understand the intersection of the nation with other social operators?

- How does the dissolution of the nation-state affect the viability and deployment of nation as a legitimating symbol in politics? ${ }^{44}$

We can discard the first and last of these questions because they are not appropriate for this study. The first questions the notion of identity - an issue 
that was addressed in the previous chapter and above, and feeds into the research questions that are explored in the following chapters. The last question locates the nation within the dissolving late-modern nation-state, an issue that is hardly appropriate for a study considering the formation of a new nationstate like Croatia.

\section{Croatia as an abstract community}

What are the processes through which abstract ideas about the national community become manifest in day-to-day social practices? This process is described by Radcliffe and Westwood as 'internalisation'. What are internalised are the various narratives that nations tell themselves about who they are and who others are. ${ }^{45}$ Paul James views nations as entities that are both abstract (in terms of their size and the fact that most of its components will never know most of its other components) and communities (in terms of the communitylike shared sentiment between national subjects). To understand how these processes work within a contemporary case study it is first necessary to translate James' insights into a series of research questions.

The first question is, how do people become national? This question directs us towards the 'big stories' of national histories that appear to permeate the historical record by asking the questions that are addressed by innumerable nationalists: where do we come from, and how do we differ from them? These big stories mark one group out from others and make it possible to draw boundaries between different nations. Moreover, they provide a set of frames for national discourses. That is, these big stories or 'frames' shape what are considered to be appropriate statements or claims about a particular nation and provide a framework for the evaluation of such knowledge claims by the broader society ${ }^{46}$ Thus, claims about Croatian national identity in the $1990 \mathrm{~s}$ tended to be made and judged by reference to the frames provided by abstract stories of national identity. Political entrepreneurs seek legitimacy and create social resonance for their programmes by offering interpretations of these abstract narratives, which of course over time change the frames themselves. However, by themselves they tell us very little about what a nation is like and how it is evolving.

The second question is, how is the nation symbolised? Another way of understanding this question is to ask how intellectuals, politicians and others attempt to give contemporary and material meaning to abstract ideas about national identity. This question frames the nation as something 'whose meaning is never stable but shifts with the changing balance of social forces' ${ }^{47}$ It raises the issue of how national symbolism and rhetoric renders some things visible and others invisible. ${ }^{48}$ It is through the rhetoric of the national self, as distinct from another, that intellectuals, politicians and others attempt to provide the nation with material meaning in contemporary contexts. This question highlights the 
competing claims that attempt to be internalised and suggests that for abstract ideas about national identity to be properly internalised by individual subjects they have to be first made intelligible and relevant to the contemporary context.

The third question addresses the context in which internalisation takes place. It asks, how can we understand the intersection of the nation with other social operators ( $^{49}$ It is based on the premise that the nation does not operate within a social vacuum. Recalling Radcliffe and Westwood's insights once again, the nation is manifested in a host of identities and social situations, and national and non-national identities are not mutually exclusive. National identity forms at the intersection of a number of identities. While interpretations of national identity impact upon and transform other identities and social practices, these in turn impact upon understandings of the nation. It is therefore important to locate national identity within a matrix that appreciates its relationship with other social operators.

These other forms of identity, be they regional, linguistic, gender, or others, affect the way that the nation is internalised by individual subjects and the meanings given to national identity in everyday practices. The way that contemporary symbols and rhetoric are understood by subjects depends upon the other identities, interests and loyalties that they hold. Furthermore, individual subjects also hold their own interpretations of the abstract ideas of national identity highlighted by Verdery's first question. These interpretations are affected by other non-national, transnational, and sub-national identities held by subjects. This complex picture of the intersection of numerous identities at the level of individual subjectivity is one of rapid change, conflict and disjuncture. This is somewhat different to the picture of continuity discovered when studying the abstract accounts of national identity covered by the first question.

These three questions suggest a way of approaching national identity that incorporates Paul James' complex ontology. ${ }^{50}$ The first of these is, how do people become national? The second is, how is the nation symbolised? Finally, how can we understand the intersection of the nation with other social operators? In responding to each of these questions, Katherine Verdery suggested different research agendas informed by different levels of analysis. What is important is that this approach is interested in the intersections between these three levels of abstraction and the ways that they relate to each other. It rejects outright the idea that one level, such as day-to-day practice, should be prioritised. The studies on Croatia that follow over the next four chapters are shaped by this research agenda.

Chapter 3 poses the question, how do people become Croats? It is suggested in this chapter that Croats understand themselves to be constituted by a continuous history of shared statehood that can be traced back to the medieval 'Triune Kingdom' of Croatia. This chapter articulates the Croatian historical narrative that is outlined in countless texts on the subject and shows how that narrative has been used at different times to substantiate alternative conceptions of Croatian national identity. Later chapters ask how intellectuals and 
politicians make this historical narrative intelligible in contemporary Croatia. As such, Chapter 4 asks, how is Croatian national identity expressed in contemporary symbolism and rhetoric? This chapter considers four different groups of accounts that were articulated in the 1990s and attempted either to furnish abstract ideas of national identity with ideational, political and material salience to secure support for particular nationalist or non-nationalist political programmes, or (in the case of the dissident intellectuals) to expose the frailties and inconsistencies of such programmes. Thus, these first two questions address the way in which different ideas about national identity compete to be internalised into the subjectivity of individuals. The final two chapters address Verdery's third question. They ask, how are competing ideas about Croatian national identity manifested in different areas of social activity? They consider how the processes of internalising national identity are affected by the social contexts in which they take place. Chapters 5 and 6 focus on six areas of social practice and consider the intersection of national identities with other social practices, institutions and identities.

\section{Notes}

1 Millennium: Journal of International Affairs, 20:3 (1991).

2 A. J. Lerner, 'Introduction to re-imagining the nation', Millennium: Journal of International Studies, 20:3 (1991), 351.

3 L. Malkki, Purity and Exile: Violence, Memory and National Cosmology Among Hutu Refugees in Tanzania (London: University of Chicago Press, 1995). 'Ethnography of displacement in the national order of things' is the title of her introductory chapter.

4 Malkki, Purity in Exile, p. 1.

5 Malkki, Purity in Exile, p. 6.

6 P. Gilroy, 'Nationalism, history and ethnic absolutism', History Workshop Journal, 30 (1990), 114.

7 Malkki, Purity in Exile, p. 202.

8 Malkki, Purity in Exile, p. 241.

9 M. Billig, Banal Nationalism (London: Sage, 1995).

10 Billig, Banal Nationalism, p. 6.

11 Billig, Banal Nationalism, p. 6

12 Billig, Banal Nationalism, p. 8.

13 Billig, Banal Nationalism, p. 8

14 Billig, Banal Nationalism, see Chapter 4.

15 Billig, Banal Nationalism, p. 10.

16 Billig, Banal Nationalism, p. 11.

17 Billig, Banal Nationalism, p. 174.

18 S. Radcliffe and S. Westwood, Remaking the Nation: Place, Identity and Politics in Latin America (London: Routledge, 1996).

19 Radcliffe and Westwood, Remaking the Nation, p. 11.

20 Radcliffe and Westwood, Remaking the Nation, p. 14.

21 Malkki and Billig suggest that alternative forms of identity can only be understood in terms of a national identity, and that a subject's understanding of other forms of identity are always conditioned by a reified national regime of truth. 
22 Radcliffe and Westwood, Remaking the Nation, p. 14.

23 Radcliffe and Westwood, Remaking the Nation, p. 14

24 Radcliffe and Westwood, Remaking the Nation, p. 16.

25 Within the field of political geography there is a growing amount of literature on the people-place nexus and the symbols, rituals and representations that tie people to place. See, for example, A. B. Murphy, 'Linguistic regionalism and the social construction of space in Belgium', International Journal of the Sociology of Language, 104 (1993), 49-64; D. Conversi, 'Reassessing current theories of nationalism: nationalism as boundary maintenance and creation', Nationalism and Ethnic Politics, 1:1 (1995), pp. 73-85; N. Johnson, 'Cast in stone: monuments, geography and nationalism', Environment and Planning D: Society and Space, 13 (1995), pp. 51-65; and J. Agnew (ed.), Political Geography: A Reader (London: Arnold, 1997).

26 Radcliffe and Westwood, Remaking the Nation, p. 23.

27 D. McCrone, The Sociology of Nationalism (London: Routledge, 1998), p. 3.

28 P. James, Nation Formation: Towards a Theory of Abstract Community (London: Sage, 1997).

29 James, Nation Formation, p. 121.

30 James, Nation Formation, p. 185. Emphasis is James'.

31 James, Nation Formation, p. 185. Emphasis is James'.

32 James, Nation Formation, p. 186. Emphasis is James'.

33 James, Nation Formation, p. 188.

34 James, Nation Formation, pp. 188-9.

35 James, Nation Formation, p. 191.

36 James, Nation Formation, p. 192.

37 James, Nation Formation, p. 184.

38 James, Nation Formation, p. 184.

39 James, Nation Formation, pp. 195-7.

40 K. Verdery, 'Whither "nation" and "nationalism"?', in E. Balakrishnan (ed.), Mapping the Nation (London: Verso, 1996), p. 226.

41 Verdery, "Whither "nation" and "nationalism"?', p. 229.

42 Verdery, "Whither "nation" and "nationalism"?', p. 227.

43 Verdery, "Whither "nation" and "nationalism"?, p. 228.

44 Verdery, "Whither "nation" and "nationalism"?, pp. 229-32.

45 See Bhabha's introduction to H. Bhabha (ed.), Nation and Narration (London: Routledge, 1990).

46 For a broader description of 'frames' and social practice see M. Barnett, 'Culture, strategy and foreign policy change: the road to Oslo', European Journal of International Relations, 5:1 (1999).

47 Verdery, "Whither "nation” and "nationalism”?', p. 230.

48 Verdery, "Whither "nation" and "nationalism"?, p. 230.

49 Verdery, "Whither "nation" and "nationalism"?, p. 231.

50 It should be noted that Verdery does not specifically cite James. For a response to Paul James see a review by A. Harvery in Australian Journal of Political Science, 32:2 (1997), 492. 


\section{3}

\section{The Croatian historical statehood narrative}

In his 1998 state of the nation address, the Croatian President Franjo Tuðman noted that with the restoration of the Croatian Danube region including Vukovar 'to our homeland', '[t]he centuries-old dream of the Croatian people has thereby been completely fulfilled'. 'Similarly, the new constitution promulgated shortly after independence proclaimed 'the millennial national identity of the Croatian nation and the continuity of its statehood, confirmed by the course of its entire historical experience in various statal forms and by the perpetuation and growth of the idea of one's own state, based on the Croatian nation's historical right to full sovereignty'.

This chapter explores these abstract claims to historical identity. At the most abstract level, Croatian national identity in the 1990s was constituted by perceptions of a common history and in particular a shared state that can claim ancient roots. Ivo Banac, for instance, noted that 'Croat national apologetics were lopsidedly historicist. The Croats never felt safe enough with strictly national - linguistic and cultural - arguments in favor of their autonomy and statehood. ${ }^{3}$ This chapter will focus on historical claims to self-rule and the ways that Croatian historians and historical narratives have tended to focus on questions of elite politics and sovereignty rather than the ethnic and linguistic claims expected by primordialists and articulated by sections of the contemporary Croatian nationalist movement. ${ }^{4} \mathrm{I}$ am not arguing that contemporary Croatian national identity is primarily constituted by reference to claims to historical statehood. As I pointed out in the previous chapter, the three levels of analysis are mutually constitutive, with none more important than the others. Neither is this chapter an attempt to chart processes of national integration in other historical epochs in a way akin to Mirjana Gross' study of the socioeconomic foundations of integration in 1850s Civil Croatia. ${ }^{5}$ Instead, it demonstrates that abstract accounts of national identity draw upon a common stock of narrative about historical statehood. These accounts provide the 
'frames' of reference used by competing politicians, intellectuals and others in the 1990s to legitimise particular political programmes. Such frames combine the real and the representational. On the one hand, representations that are wildly at odds with established knowledge tend to be disregarded. The historical statehood narrative could not be sustained and would not be resonant were it a complete fiction. On the other hand, knowledge about what is real is mediated through representation.

\section{The search for ethnic origins}

Although from time to time Croatian nationalists have attempted to articulate an ethnic account of national identity, these have tended to flounder on the impossibility of locating ethnic antecedents. ${ }^{6}$ The one thing that all historians agree on is that the Croats were not the earliest inhabitants of the lands that make up present day Croatia. Key questions for those interested in articulating an ancient ethnic origin for Croatian national identity therefore include whether or not the Croats were Slavs and, if so, how closely they were related to other Slavic groups. Also, such writers need to address how the Croats came to occupy the Roman lands of Pannonia and Dalmatia.

Ivo Banac's understanding of the migration of Slavs into the region is that they came to the Balkans as permanent largely agrarian settlers whose advent can be divided into several stages. In the first decades of the sixth century they aided numerous invaders such as the Avars and Huns in attacks over the borders of the Byzantine Empire. Unlike some other writers, Banac does not believe that these Slavs were sub-divided into pre-national groupings such as Slovenes, Serbs and Croats.

Other writers, however, contend that it is possible to distinguish the Croats from other Slavic groups and, as we shall see later, this is vital to accounts that attempt to trace Croatian national identity back to a prior ethnic group. Marcus Tanner used texts ascribed to Emperor Heraclius to suggest that the Croats began inhabiting the provinces of Pannonia and Dalmatia after the sack of Split by the Avars in AD 614. According to Tanner, the Emperor claimed that the Croats were distinguished by being Aryans and heretics until their incorporation into mainstream Christianity in the middle of the seventh century. ${ }^{8}$ Stephen Gazi supported the view that the Croats were a distinguishable group who settled in Pannonia and Dalmatia around the sixth and seventh centuries. ${ }^{9}$

The most popular explanation is that the Slavs were a diverse and disunited group and that there were indeed recognisable differences between different Slavic groups. According to Emperley, the Slavic tribes were scattered and numerous and recognised no external authority. Furthermore, the Slavs were 'split up into several distinct groups which are approximately those of today'. ${ }^{10}$ This view was supported by Roger Portal who argued that ' $[t]$ here is at the present time no specifically Slav civilization, common to all the Slavs ... and in 
all probability there never has been'. ${ }^{11}$ Furthermore, Portal insisted that other than sharing linguistic characteristics the Slavs exhibited more differences than similarities. ${ }^{12}$ The view that the Slavs migrated from one particular area is also dismissed, as George Hoffman suggested that Slavic tribes descended on the Balkans from every conceivable direction, adding to the difficulty of speaking of the Slavs as a common ethnie. What can be determined is that it was in this milieu of migration and conflict that a group (or groups) that came to be known as 'Croats' settled in the territories that make up present day Croatia.

One of the most basic statements concerning the Croats is that they are ethnically Slav, though as we have seen it is probably problematic to consider the Slavs as an ethnie. Simon Vladovich contended that most sources agree that the Croats were a Slavic group of tribes who lived northeast of the Carpathian Mountains between the Dnieper and Dniester rivers. ${ }^{13}$ They then journeyed to north-central Europe where they created the state of White Croatia before migrating southwards in the seventh century ${ }^{14}$ However, there are some discrepancies with this account. Stanko Guldescu pointed out that in the Book of Annals, written by Alfred the Great of England (871-901), there is mention of a state known as White Croatia with its seat in the Polish city of Krakow - some 150 years after the Croats were supposed to have taken Pannonia and Dalmatia. ${ }^{15}$

Roger Portal agreed that the Slavs probably originated from the Carpathian region but did not give any credence to the idea that separate groups took different routes to the Balkans. ${ }^{16}$ However, Ferdinand Schevill offered an entirely different geographical starting point for the Slavs - the marshes of Ukraine. ${ }^{17}$ Given these disagreements, we cannot simply accept that the Croats were either an indistinguishable Slavic group intermingled with the rest or (if we accept Vladovich's account) an identifiable group that took an alternative route to the Balkans. Furthermore, several ethnic nationalist historians have questioned whether the Croats were Slavs at all.

There are several historical anomalies that support the view that the Croats were not a Slavic group. For example, some writers argued that the name 'Croat' suggested an Iranian origin. ${ }^{18}$ The claim that Croats originally resided in Iranian lands is based on an interpretation of what the word 'Croat' means. According to Constantine Porphrygenitus, the Croats were simply 'the people with many lands', while Jan Safaryk argued that the idea of Carpathian roots is substantiated in the name. ${ }^{19}$ Some Croatian scholars opted for this theory, arguing that Greek accounts of a community called Horvatos or Horoatos, which occupied a region of Iran, reveal the first evidence of the existence of the Croats. ${ }^{20}$ The Russian historians, Pogodin and Miler, who discovered Iranian inscriptions bearing the name Horuatus, also supported this view. ${ }^{21}$ However, there is a major problem with this theory. The reason for the Slavic migration appears to have been the search for better land and an escape from the Carpathian mountains and marshes. ${ }^{22}$ To locate the Croats in fertile Iran, therefore, makes their migration inexplicable.

After the Napoleonic Wars, several Croatian intellectuals conceived the 
idea that the Croats were in fact descendants of Illyrians, the first known inhabitants of the Balkan Adriatic coast..$^{23}$ This account can be easily dismissed. Although it is not fully known what became of the Illyrians, there is substantial evidence that they were expelled by the Avars and Croats. Other theories describe the Croats as an Aryan Gothic group, Samartian, ${ }^{24}$ and Ukrainian. ${ }^{25}$ There is archaeological evidence that seems to support a non-Slavic theory of Croatian ethnicity. Most notably, helmets were found in the eighth-century graves of Croats, while it is generally thought that the early Slavs did not wear helmets. ${ }^{26}$

This brief survey indicates that it has proven impossible to point to an ethnic predecessor to Croatian nationhood, even though many writers have tried to do so. It is difficult to tell who the Croats were prior to the first Croatian kingdom. This suggests that rather than being a single ethnic group they were a collection of tribes, a mixture made all the more confusing by their interaction with the earliest inhabitants of Pannonia and Dalmatia. It is only with the advent of a Croatian state that it is possible to speak about Croats with any clarity. As such, it is difficult to make the case for the existence of an ancient ethnic antecedent to Croatian national identity because such an antecedent is impossible to find and is not acknowledged by all but the most extreme of Croatian nationalist intellectuals. This could begin to explain why it is that Croatian claims to national sovereignty in the 1990s were made by reference to a discourse of historical statehood rather than in the ethnic terms that Serbs used to justify their rule over Kosovo. ${ }^{27}$ The Croatian narrative of historical statehood, the abstract story of national identity, is therefore primarily concerned with constitutional arrangements and political programmes.

\section{The Croatian claim to statehood}

The narrative of the historic claim to statehood begins at the start of the 'centuries-old dream' in the form of the medieval Croatian state. The Croatian constitution recalls 'the formation of Croatian principalities in the seventh century', 'the independent medieval state of Croatia founded in the ninth century' and 'the Kingdom of Croats established in the tenth century' ${ }^{28}$ It is on the basis of the medieval state that the Croats make their historic claim to national sovereignty, tracing a continual line of political independence from the time of King Tomislav to the formation of the Kingdom of Serbs, Croats and Slovenes in 1918. The central debates in Croatia's national historiography are not ones of ethnicity or religion, but ones of national governance and sovereignty. Such debates include the exact nature of the coming together of the Hungarian-Croatian union in 1102, the status of Croatia within that union, and the question of whether the Croatian parliament (Sabor) agreed to Croatia joining the South Slav state that was formed at the end of the First World War.

According to most, if not all, Balkan historians, Croatia became a unified kingdom in 924 when Tomislav assumed the title of King of Croatia and 
Dalmatia. ${ }^{29}$ The coronation was recognised by the Pope and thus Croatia began a period of just under 200 years of rule by Croatian kings. ${ }^{30}$ The geographical extent of Tomislav's Croatian state is not fully known and is widely disputed. Tanner suggested that it comprised most of modern Croatia, Bosnia and Hercegovina, and the coastline of modern Montenegro. ${ }^{31}$ Roger Lampe, however, argued that the Croatian state did not penetrate as far south as Dubrovnik, let alone Montenegro, and that Istria was also not included in this state. This view is supported by many Croatian scholars, who argue that the medieval Croatian state extended to the whole region south of the Drava River to the Drina and Neretva Rivers (north of Dubrovnik). ${ }^{32}$ However, the Byzantine chronicler, Porphyrogenitus argued that the Croatian state extended to the entire coastline from Istria to the River Cetina (in Montenegro - south of Dubrovnik). ${ }^{33}$ Importantly, though, most agree that Tomislav was able to unite Pannonian (northern) Croatia with coastal Dalmatia, a union that formed a major part of the so-called national dream of the Croats. ${ }^{34}$

Many of the symbols used by the contemporary Croatian state trace their heritage back to the medieval kingdom. The chequerboard coat of arms, the Sahovnica, is widely thought to have been created in the tenth century by one of Tomislav's predecessors, Stjepan Držislav. ${ }^{35}$ Similarly, the Kuna was developed as a form of currency during this period, its first known use being on the Island of Cres. ${ }^{36}$ The Kuna reappeared as the currency in the 1990s when the Yugoslav Dinar was abandoned. ${ }^{37}$

Along with Tomislav, one of the most significant ancient Croatian kings was Krešimir Petar (1058-74). Krešimir reportedly consolidated the kingdom by unifying the lands into a single kingdom, calling it the Triune Kingdom (CroatiaSlavonia-Dalmatia). ${ }^{38}$ Krešimir's death left the throne vacant, leading to many years of plot and counter-plot among the nobles. Eventually, in 1102, the nobles decided that Croatia should enter into a personal union with Hungary whereby the Hungarian king would be crowned separately as the King of Croatia.

The narrative therefore tells us that Croatia's brief period of statehood came to an end amidst the intrigues of the nobles. The events surrounding the union of Croatia and Hungary are the source of a major historical controversy. Its importance derives from the fact that the historical statehood narrative depends upon the establishment of a continuous line of statehood. Intellectuals and politicians have not tended to concern themselves with the identity of the people who were ruled by the Croatian nobles, only with asserting that there was a continuous line of statehood. According to Croatian historians, then, the nobles gave the throne to Hungary but never lost their independence or sovereignty. Magyar historians, however, claim that Hungary conquered Croatia. The significance of the debate lies in the Croatian claim to an unbroken heritage of historical statehood, which is clearly compromised by the Magyar claim. Perceptions about the exact nature of the union are therefore vital to establishing an abstract idea of Croatian national identity that is based on a continuous line of statehood. 
It is argued that in 1102 the Croatian nobles signed an agreement - the Pacta Conventa - with Koloman, King of Hungary. This agreement confirmed the legitimacy of Koloman's succession to the Croatian throne in return for which Koloman agreed to respect the laws and customs of Croatia. ${ }^{39}$ The exact nature of the agreement, and even its existence, is impossible to determine as historians believe that a transcript of the Pacta Conventa preserved in the city of Trogir is actually a fourteenth-century fake. ${ }^{40}$ There are two competing accounts of the nature of the union, one emerging predominantly from Croat historians and the other from Magyar and Serbian historians. The Croats argue that the union was a personal one in the form of a shared king, while the Magyars and Serbs insist that Croatia was conquered.

The Croatian position was recorded by Despalatović in her work on the nineteenth-century Illyrianist nationalist Ljudevit Gaj. Gaj insisted, 'let it be known to Your Majesty that no ruler has ever subjugated Croatia by force. Rather, after the death of our last king, Zvonimir, we of our free will attached ourselves to the crown of the Hungarian kingdom, as we at this time join ourselves to Your Majesty. ${ }^{31}$ The claim made by Croatian historians is that a continual line of independent statehood can still be traced through the period of the union with Hungary because it was a voluntary union freely entered into by the Croatian nobles. This view of events has a wide circle of support. Ivo Banac contended that, with the death of the last Croatian king, the crown simply passed into royal Hungarian hands as the nearest blood relation to the Croatian Trpimir dynasty. ${ }^{42}$ The existence of such an agreement, and the accuracy of these Croatian claims, is partially supported by evidence of early practices in the 'union'. First, during the first two centuries of the union there were separate crowning ceremonies, one ceremony for the crowning of the King of Hungary and one for the crowning of the King of Croatia. ${ }^{43}$ Second, there is evidence that the Croats continued to make their own laws in their own parliament (Sabor), under their own leaders (Bans), who convened the Sabors and promulgated laws without the King's sanction. ${ }^{44}$ Third, compared to the other 'conquerors' of Croatian lands (principally the Venetians and Ottomans) there are hardly any archaeological reminders of Croatia's union with Hungary, suggesting that the Magyars did not forcibly impose themselves on the Croats. ${ }^{45}$ Finally, prior to 1526 the dukes and Bans of Croatia produced their own currency in Zagreb. These items of currency were engraved with the Croatian coat of arms and the symbols of Croatia and Dalmatia that form part of the present day Croatian flag. ${ }^{46}$

There is, however, an alternative account of events leading up the union of 1102. Whereas many Croatian historians and politicians are determined to trace an unbroken line of sovereign statehood, several Magyar and Serbian historians have been equally determined to undermine these claims. According to Branimir Janković, the Magyars 'swept' into Pannonian Croatia. ${ }^{47} \mathrm{He}$ insists that '[a]fter armed resistance, the Croatian nobility had to yield to superior Hungarian might'. ${ }^{48}$ According to this view, Koloman seized Croatia by force of 
arms, discrediting Croatian claims to continual statehood. ${ }^{49}$ However, there are a couple of points that need to be made about this thesis. Firstly, Magyar claims were not made until the middle of the nineteenth century and formed part of the Hungarian national reawakening under Kossuth (of course, much the same argument could also be levelled about the idea of a personal union first articulated in the fourteenth century). ${ }^{50}$ Second:

[T] he idea that Koloman and his Magyars conquered Croatia by force rests upon the supposition that there was a counter king whom he had to overthrow to accomplish his ends. There is no real evidence that there was any organized opposition at all to his invasions, if it can be called that of the Croatian lands. It should be remembered that there probably was no fixed border between Hungary and Croatia in the eleventh century ... when the House of Trpimir disappeared ... the frontier disappeared too. ${ }^{51}$

It is not the exact nature of the relationship between Croatia and Hungary from 1102 that is of interest to us here but the importance attached to defending the idea of a personal union that is central. The historical statehood narrative insists that it is possible to trace a long history of parliamentary declarations reasserting the Croatian view of events in 1102. For instance, in the early eighteenth century the Sabor declared that 'Croatia as a kingdom was joined with Hungary, but without establishing common citizenship. We were not compelled by force to join Hungary. We accepted only her king and not the kingdom ... we are free citizens and subjects to no one. ${ }^{52}$

This view of history is enshrined in the contemporary Croatian constitution, which asserts the 'preservation of the subjectivity of the Croatian state in the Croatian-Hungarian personal union'. ${ }^{33}$ The union of 1102 therefore represents Croatia's second claim in the historical statehood thesis: the medieval state of Croatia was not demolished but was retained under a personal union between Hungary and Croatia. The actual nature of the relationship is probably most accurately described as being inexplicable in modern terms because it varied from time to time. Sometimes Croatia acted as an independent agent and at other times as a vassal of Hungary. However, throughout this period, 'she [Croatia] retained a large degree of internal independence'. ${ }^{54}$

The next 'signpost' of the Croatian historical statehood narrative is 1526 and the defeat of Hungary by the Ottoman Turks, which prompted Croatia's entry into the Habsburg Empire. Again, the Croatian historical narrative insists that the decision to join the Habsburg Empire was the result of a free choice made by the Sabor. On 29 August 1526, the Ottoman Turks defeated the Hungarian army at the battle of Mohacs. ${ }^{55}$ The battle was particularly devastating for the Hungarians because the last male of the ruling family, Louis Jagellon, was killed, leaving the thrones of Hungary and Croatia without an heir. ${ }^{56}$ According to the Croatian narrative of historical statehood, the Sabor decided to remedy the problem by electing the Habsburg king, Ferdinand, to the Croatian throne. Thus, according to many Croat historians, 'the nobility, entirely of their own 
accord and free from foreign influence, elected Ferdinand ... King of Croatia'. ${ }^{57}$ The Sabor took the opportunity to reassert its autonomy from Hungary by reaffirming the events of 1102. It reputedly declared that, 'after the death of Zvonimir, our last king of fond memory, we joined the holy crown of Hungary by our own free will, just as we do now, the rule of Your Majesty' ${ }^{58}$ Croatian historians also argue that the struggle for ascendancy to the Habsburg throne at this time provides evidence of Croatia's political autonomy. Guldescu, for instance, argued that evidence suggesting that Ferdinand's rival, Zapolya, had to abandon his claim to the throne of Croatia-Slavonia demonstrates Croatia's separate political identity. ${ }^{59}$ Other historians suggest that the Sabor attached conditions to the offer of the crown, such as maintenance of Croatian autonomy and assistance in the defence against Ottoman attack..$^{60}$ Unlike Magyar historians, the Austrians never claimed that they conquered Croatia by force and there appears to be little reason to doubt Croatian claims about the events of 1526 .

The incorporation of Croatian lands into the Habsburg Empire further complicates attempts to trace a continual history of Croatian statehood, because the Sabor became enmeshed in a political framework with two other powers: Austria and Hungary. One of the central debates within Croatian national politics up to the formation of the Kingdom of Serbs, Croats and Slovenes in 1918 was the question of whether to align with Vienna or Budapest. ${ }^{61}$ As a result, the lands of the medieval kingdom became even more divided in this period. Slavonia was separated from Croatia proper, while what was left of Croatia was separated into the military frontier (Vojna Krajina), which was administered directly by the Emperor, and Civil Croatia, administered by the Sabor. ${ }^{62}$ The lands comprising present-day Croatia were divided into five entities. Three of them (Civil Croatia, Slavonia and Vojna Krajina) fell under the rule of the Habsburgs, and the other two (Dalmatia and Istria) were ruled by the Venetians. ${ }^{63}$ It is important to note that northern Croatia and Dalmatia were ruled separately throughout this period and remained so until the formation of the Kingdom of Serbs, Croats and Slovenes after the First World War. This creates further problems for the narrative of historical statehood because after the dissolution (voluntary or otherwise) of the medieval kingdom as many people identified as Croats by their inhabitance of the medieval kingdom lived outside Habsburg Croatia as within it. By the time Dalmatia came under Habsburg rule after the fall of Napoleon the empire was split into the dual Austro-Hungarian monarchy, with Vienna ruling Dalmatia and Budapest ruling Slavonia and Croatia proper. From 1526 onwards, therefore, the historical statehood narrative also has to trace a history of political activism aimed at unifying the disparate lands of the medieval kingdom.

One of the most significant legacies bequeathed by the Habsburgs was the military frontier (Vojna Krajina), which was established on the border of the Habsburg and Ottoman Empires. Groups residing in the Vojna Krajina came under the direct authority of the Habsburg Emperor, creating further divisions 
in the Croatian polity. ${ }^{64}$ In return for military service in the Habsburg armies, the frontiersmen were exempt feudal dues and were loaned land by the Emperor. ${ }^{65}$ They were also awarded special religious exemptions, which were important for the accommodation of Orthodox Serbs and Vlachs migrating from the Ottoman Empire. ${ }^{66}$ In return for concessions and exemptions, the Emperor secured a cheap source of manpower with which to garrison the frontier. ${ }^{67}$ As a result of numerous wars with the Ottomans and the constant cross-frontier raiding, the Vojna Krajina became depopulated and hence more vulnerable to Ottoman incursion. The Habsburgs therefore encouraged the settlement of Orthodox Christian Serbs and Vlachs who were migrating from Ottoman-held territory ${ }^{68}$ The historical statehood narrative recalls that the Vojna Krajina galvanised Croatian national sentiment by providing a focus for political mobilisation. From its establishment until its reincorporation with socalled Civil Croatia in the nineteenth century, the Sabor constantly demanded that Zagreb be allowed to exert its authority over Vojna Krajina and effectively reunite the lands of today's northern Croatia. ${ }^{69}$

\section{The national awakening}

The campaign for uniting the different entities that had comprised the medieval kingdom lay at the heart of the national movement when Croatian national identity started to be more clearly articulated during the nineteenth and early twentieth centuries. The growth and development of Risorgimento-type nationalism in Croatia has often been attributed to the brief period of occupation by Napoleonic France at the beginning of the nineteenth century. However, the precise nature of the French legacy and its relationship to the historical statehood narrative is contested. On one hand, many nationalists attribute the birth of the national movement to the ideas of self-determination articulated by the French. On the other hand, communist historians argue that all forms of imperialism must be pernicious. Moreover, some Croatian nationalist historians agreed with the communists because they wanted to emphasise the positive links between Croatia and Austria as a way of challenging panSlavism and denying the significance of subjugation to the French, which could potentially challenge the idea of continuous statehood..$^{70}$

During the Napoleonic War, the Croatian army fought on the side of the Habsburg Empire against the French. ${ }^{71}$ Under the 1797 Treaty of Campoformio, most of the territory comprising present-day Croatia and Slovenia (including Dubrovnik) was transferred to French control. Napoleon decided to resurrect the ancient name of Illyria as a geographical and administrative term for his new acquisitions, a change that was apparently welcomed by Italian-educated Croatian intellectuals, who understood the liberal and potentially revolutionary implications of the name. ${ }^{72}$ In 1810 Marshal Marmont arrived in the province with the task of incorporating it into the French Empire. Although short-lived, 
Marmont's reforms were extensive. He introduced the Code Napoleon, which formed the basis of French law and provided for the abolition of serfdom, equality before the law, and an independent judiciary. He also attempted to introduce free trade, something that had been suppressed by previous imperial overlords. Most crucial for the development of Croatian nationalism, however, were the linguistic and educational reforms. A quasi-universal school system was introduced, which began teaching the Štokavian dialect of the Croatian language. This dialect also became the official administrative language of Croatia for the first time since the medieval kingdom. Marmont encouraged writing and printing in the Croatian language and allowed Vincenze Dandolo to produce the first ever periodical in the Croatian language - Kraglski Dalmatin. ${ }^{73}$

The place of Marmont's reforms in the historical narrative is disputed. One view is that the French occupation was of immense significance to the development of Croatian national identity. Napoleon integrated most of the Croatian lands (including Croatia, Dalmatia, Istria, Vojna Krajina and Dubrovnik, but omitting Zagreb) into the Illyrian province, making them a single entity for the first time since the venerated Triune Kingdom. The abolition of serfdom broke down the legal distinction between nobles and peasants and created the possibility for the development of a larger urban middle class. Moreover, by promoting the use of the Croatian language and the idea of universal compulsory education, Marmont's reforms facilitated the development of a national literature. ${ }^{74}$ As Kann argued, 'probably the Illyrian peoples perceived the basis of their brief prosperity not so much in the enlightened spirit of the reforms introduced by a foreign conqueror as in the fact that under the French regime they had been united for the first time in many centuries..$^{75}$

However, many nationalist writers opposed the idea that the French occupation may have contributed to national developments seeing in it instead a further challenge to the idea of continuous statehood. As Guldescu put it, 'it is altogether erroneous to hold that the Croatians ever welcomed or were satisfied with the change in sovereignty.$^{76} \mathrm{He}$ pointed to the bitterness caused by the abolition of the Dubrovnik Republic and the fact that Croatian troops fought for Austria rather than France as indicative of the absence of co-operation between the French and Croats that is implied in the other accounts. He also pointed out that the French regime increased taxes, causing further resentment among Croatian peasants. It is also likely that the illiterate peasants would not have understood Marmont's enlightened reforms and that the significance of the union of Dalmatia with Croatia would have been lost on them. ${ }^{77}$ After Napoleon's defeat at Waterloo, the Illyrian provinces were restored to the Habsburg Empire and Marmont's reforms were swiftly revoked. Following the Napoleonic Wars, Croatian intellectuals and politicians came to regard Austria as a potential ally against the threat of Magyarisation produced by the development of nationalism in Hungary. According to many contemporaries, closer union with Austria would allow a reassertion of Croatia's historic stateright that had been eroded by the Magyars. 
The primary threat to the development of an independent Croatian political identity within the Habsburg Empire is widely understood to have been the emergence of the Magyar nationalist leader, Kossuth. This new nationalist movement attempted to establish a single centralised Kingdom of Hungary stretching from the Carpathian Mountains in the north to the Dalmatian Adriatic Sea in the south. ${ }^{78}$ The idea of such a kingdom threatened to eradicate any semblance of Croatian political autonomy. Between the end of the Napoleonic Wars and the liberal revolutions of 1848, the Magyar nationalists embarked on a Magyarisation programme in Croatia. For example, they insisted that the Magyar language be taught in schools and used for all official purposes. Dalmatia was spared this process, however, because under the terms of the 1815 Versailles Treaty it came under the direct authority of Austria.

By the mid-nineteenth century, therefore, the historical statehood narrative confronts two challenges: the battle against the Magyar nationalists and the fact that the Croatian lands were divided. These two factors make it potentially very difficult to trace a continual line of statehood, prompting historians to look instead for evidence of Croatian political actors fighting against Magyar nationalism in the cause of Croatian unification. These circumstances helped produce one of the heroes of the Croatian historical narrative, Ban Josip Jelačić. It is perhaps odd that one of the heroes of Croatian nationalism should be a servant of Vienna, but this veneration only serves to emphasise the political and historical rather than ethnic base of abstract conceptions of Croatian national identity. Indeed, one of the first acts of the new Croatian government at the beginning of the 1990s was to restore a statue of Jelačić that had been removed by the communists. Ironically, that statue - a symbol of Croatia's national history given pride of place in Zagreb's central square - was first built and erected by Austria not Croatia.

Jelačić gained 'tragic hero' status for his successful campaign that defended the Vienna Habsburgs against Kossuth's nationalist Hungarian army. He hoped that through his loyalty to the Empire he would persuade the Habsburgs to unite the Croatian lands in a sovereign and autonomous state that would share the same status as Hungary. ${ }^{79}$ In 1848 Magyar nationalists revolted against the Austrians, aiming to create an exclusively Hungarian empire. Jelačić led the Croatian army in a successful war against the Magyars. Indeed, it was the Croatian army that prevented the Magyars taking Vienna before the Russians intervened and suppressed Kossuth and his followers. Despite his loyalty to Vienna, Jelačić's efforts failed to secure greater autonomy for Croatia. A cruel but accurate joke that was frequently recited opined that following the events of 1848-49 Croatia received as a reward from the Habsburgs what the Magyars received as a punishment. ${ }^{80}$ Communist historiography branded Jelačić a reactionary, but he was venerated by nationalists, despite the fact that his loyalty ultimately lay in Vienna rather than Zagreb.

Twenty subsequent years of constitutional bickering between the Sabor and the Hungarians produced the Nagodba (compromise), which tried to define 
Croatia's status and in doing so marked an important justificatory landmark for the historical statehood narrative. The Nagodba recognised that Croatia was 'a political nation possessing a special territory of its own' ${ }^{81}$ It also provided for provincial autonomy under the Sabor in Zagreb and established Croatian as the official language for all autonomous and common affairs pertaining to the Croatian territory. Finally, it provided for the eventual return of the Vojna Krajina to the civil administration of Croatia. ${ }^{82}$ As with most aspects of the historical narrative there is strong debate about the meaning of the Nagodba. In particular, nationalist historians point out that it recognised Croatia's historic right to statehood, while others have pointed to the great disappointment felt by Croatian politicians and intellectuals. ${ }^{83}$ Grievances centred on the constraints placed upon the autonomy of the Sabor. All important decisions regarding the Croatian economy and transportation were to be taken in Budapest, and the head of the autonomous government, the Ban, would be appointed by the Hungarians and would still be answerable to the Hungarian Diet rather than to the Sabor. Dalmatia remained under Austrian authority, despite pledges to unite it into the Triune Kingdom, and Hungary annexed parts of Slavonia. ${ }^{84}$ On the one hand, the Nagodba offered succour for proponents of the historical statehood narrative by acknowledging that Croatia was separate from Hungary. On the other hand, it re-emphasised the separation of the lands of the medieval kingdom, which made the historic statehood claim more problematic.

\section{Competing national ideologies}

Although the historic statehood thesis claims that Croatian national identity is based on the idea of shared history and statehood, the first nationalist movements that developed in the second half of the nineteenth century put many different ideas forward about what Croatian national identity was and where it came from. These competing ideologies had two important consequences for the historical statehood narrative. First, for the first time different national ideologies were developed that made use of competing interpretations of the historical statehood narrative. Second, these different national ideologies produced different political ideologies in the twentieth century. One of the tasks that confronted Tuðman in his attempt to enforce a particular understanding of national identity in the 1990s was to unite these different national ideologies. We will see how he tried to do this in the following chapter, but it is worth noting here that these different understandings of national identity ultimately proved impossible to unite, although they all made use of the frames provided by the historical statehood narrative.

The first and most prominent of the nineteenth-century national movements was the Illyrian movement. In the early and mid-nineteenth century many members of the Croatian intelligentsia believed that the best way to combat Magyarisation was to embark on a counter-Magyar national programme. 
This programme, which also articulated a linguistic alternative to Hungarian and Latin, began in the 1830s and 1840s and became known as the Illyrian movement. ${ }^{85}$ Initially, Illyrianism was a cultural movement inspired by the poetry of Ljudevit Gaj and Janko Drasković, but after 1841 it became the dominant political and national ideology among intellectuals and the bourgeois strata of Croatian society under the tutelage of Bishop Josip Strossmayer.

Ljudevit Gaj was a student of law at the universities of Graz and Budapest, where he was influenced by the Slovak nationalist Jan Safaryk. Gaj proposed the introduction of diacritic signs for the Latin alphabet as a way of spelling Croatian words. Underlying Gaj's work was an attempt to establish a common identity for all Croatian peoples through the creation of a common literary language and the claim that those who shared this linguistic identity had the right to determine the nation's future. ${ }^{86}$ Gaj reintroduced the term 'Illyria' in order to transcend the national differences between Croats, Serbs and Slovenes, and he argued that the Southern Slavs were direct descendants of the Illyrians. ${ }^{87}$ Gaj argued that the establishment of a common literary language was essential for the development of an Illyrian national consciousness and he attempted to bring together the three main dialects used by the Southern Slavs - Štokavian, Cakavian and Kajkavian - into a single literary language. ${ }^{88}$ For Gaj, it was only through the establishment and dissemination of such a language that Croatia could withstand the onslaught of Magyarisation. In 1827 he wrote that 'in an illiterate land such as ours, it seems important, yes, most necessary to bring all powers to bear upon awakening an effective and noble cultural patriotism ... The story of our fatherland has already taught me how much it deserves to be lifted out of the miserable Magyar darkness. ${ }^{89}$ For Gaj, Illyrianism was about establishing a Southern Slavic or Croatian high culture through which a national identity could be established as a means of challenging Magyar nationalism. He established a Croatian newspaper written in the Stokavian dialect that was closest to the Serbian language, and encouraged the establishment of reading rooms and political clubs. ${ }^{90}$ Gaj was also involved in the founding of Matica Hrvatska, a patriotic society that published and disseminated books in the Croatian language. ${ }^{91}$

Illyrianism later became more political than cultural and eventually gave birth to a political party. As it did so, its proponents began to make use of the historical statehood narrative. These initiatives were led by Bishop Josip Strossmayer, who is often accredited with being the 'first Yugoslav'. ${ }^{92}$ Strossmayer believed that the term 'Illyrian' was an artificial and foreign word, so he replaced it with 'Yugoslav' (South Slav). ${ }^{93} \mathrm{He}$ was disillusioned with both the Habsburgs and the Hungarians and sought an alternative path by building upon Gaj's attempts to establish a common literary language for all Southern Slavs. Strossmayer established the Yugoslav Academy of Arts and Sciences in Zagreb, which he hoped would give the new nation its own intellectual life to parallel the Magyar, Austrian and Italian intellectual establishments. Strossmayer also took the issue of Serb-Croat unity a stage further by working on a 
programme to transcend the differences between Orthodox and Catholic Christianity, which he believed hampered possibilities for a Serb-Croat union. ${ }^{94}$ His interest in reconciliation with the Orthodox churches was not reciprocated in Serbia, where he was regarded as a cunning spokesperson for Rome. ${ }^{95}$ This recalcitrance caused Strossmayer's eventual disillusionment with the Yugoslav project. ${ }^{96}$

The cause of Serb-Croat unity articulated by these Croatian intellectuals was never received well in Serbia. According to Ivo Banac, the principal reason for this was that Strossmayer refused to rule out Croatia's claims to historic statehood. Although the Illyrianists sought to unite the Southern Slav people, they still maintained the principle of Croatia's right to statehood. ${ }^{97}$ This was unacceptable to the Serbs, who envisaged a possible Yugoslav state as more akin to a 'Greater Serbia' than the loose federation envisaged by the Illyrianists. Nevertheless, at the beginning of the 1840s the movement became a fully fledged political party whose programme consisted of the establishment of Štokavian as a literary language for the southern Slavs, the unification of all Croatian lands within the Habsburg Monarchy, and the attainment of closer ties with Bosnia-Hercegovina, Serbia and Bulgaria. ${ }^{98}$

Although Illyrianism is the most widely discussed nineteenth-century national ideology, it was by no means the only one. According to Mirjana Gross, it is possible to identify five different national ideologies that developed in Croatia during this period. ${ }^{99}$ These she described as: Illyrism (Illyrianism), Yugoslavism, the Party of Right, the peasant movement and social democrats. Gross outlines a typology in which Illyrianism, Yugoslavism and the social democrats stand juxtaposed to the others, who articulated exclusive Croatian nationalism. Within this typology, though, there is a clear distinction between the Illyrianism of Strossmayer and Gaj, which envisaged some form of loose union between the Southern Slavs including the Bulgarians, and the unitary Yugoslavism of Trumbić and Supilo that informed the work of the Yugoslav Committee in London during the First World War. ${ }^{100}$ Outside the intelligentsia, the Party of Right and the Croatian Peasants' Party (HSS) were the most popular. Interestingly, although these ideologies spanned the political spectrum, they all made use of particular interpretations of the historical statehood narrative.

The Party of Right (HSP) was founded in the 1860s by Ante Starčević and Eugen Kvaternik. The old Croatian constitution provided the foundation for their political programme and they believed that the only power that the Croats should deal was that of the King of Croatia-Slavonia and Dalmatia - the Emperor of Austria. ${ }^{101}$ Starčević was one of the leading critics of the Nagodba, which he believed negated Croatia's right to statehood. The cornerstone of Starčević's ideology was the maintenance of this perceived historical right to statehood. ${ }^{102} \mathrm{He}$ demanded the creation of a 'great Croatia', encompassing Croatia, Slavonia, Istria, Dalmatia, Dubrovnik, and Bosnia and Hercegovina. ${ }^{103}$ More troubling was the fact that Starčević downplayed the religious differences between Croats and Serbs by arguing that the Serbs of Bosnia and Vojna Krajina 
were merely Orthodox Croats, who, like the Bosnian Muslims, would voluntarily acknowledge their tie to the historic Croatian nation once it was shown to them. ${ }^{104}$ The national ideology of the Party of Right was thus firmly rooted in the idea of the Croats as a 'political people' who had a historic right to statehood enjoyed since the ninth century. This 'primary acquisition' established 'the eternal and natural Croat right to ownership of the land' ${ }^{105}$

The only political movement to command substantial support outside the economic and intellectual elite was Stjepan Radićs Croatian Peasant Party, which competed its first election in $1905 .{ }^{106}$ Radić was convinced that the future belonged to the Croatian peasantry and espoused both the doctrine of Croatia's state-right and the continuation of the Habsburg Monarchy, albeit a reformed Monarchy that would be both democratic and federal. ${ }^{107}$ Under Radićs programme, the Kingdom of Croatia would be a federal state in which the Croats, Slovenes and Serbs who lived in the Habsburg Empire would organise their own affairs, leaving those who lived outside the Monarchy to organise themselves into a separate Yugoslav state if they so desired..$^{108}$ On culture and language, the Radić favoured the establishment of a folk-peasant culture that would transcend the traditional divisions of nation and religion, allowing Serbs and Muslims to participate in the movement. However, it proved problematic to equate peasant republicanism, Croatian exclusivism (keeping Croatia out of Yugoslavia) and a commitment to the Monarchy, prompting Radić regularly to contradict himself. ${ }^{109}$ Hence, it was only after the formation of the Kingdom of Serbs, Croats and Slovenes that the Peasants' Party (HSS) became the leading party in Croatia and Radić's vision assumed some degree of consistency.

The range of national ideologies in Croatia in the nineteenth and early twentieth centuries therefore included Yugoslavism, Croatian exclusivism and Austrianism. Importantly, despite the variety of political programmes put forward by these ideologies, they all shared three common traits. First, they all demanded the unification of Croatia, Dalmatia, Slavonia and Istria. Second, they were democratic to some extent and wanted to see the Sabor exert more control over Croatia. Finally, they called for a constitution that acknowledged Croatia's historic right to statehood. ${ }^{110}$ Each of these ideas draws upon the historical statehood narrative, suggesting that it provided a powerful frame for Croatian political rhetoric and activism. With the dissolution of the Habsburg Empire at the end of the First World War, the Croatian elite was presented with a threefold dilemma about the direction it could take. The options were: remain inside Austria, declare national unification and independence in a revived Triune Kingdom, or enter into a union with the Serbs and Slovenes. Most Croatian historians argue that while the majority of Croats favoured either the first or second option, the elite (which consisted of a high proportion of Serbs) opted for the third without consulting the will of the people or the Sabor. Thus the events of 1918 should be ranked alongside 1102 and 1526 as a defining and controversial moment in the historical statehood narrative. 


\section{Croatia and Yugoslavia}

These different ideologies remained after Croatia entered the Kingdom of Serbs, Croats and Slovenes. The question now though was not one of how Croatia should relate to Hungary but how it should relate to Serbia. The first forty years of the twentieth century also added two new national ideologies that made the task of unifying them in the 1990s all the more problematic. These were the powerful and diametrically opposed ideologies of fascism and communism. Despite these developments, the main debates about Croatian national identity in the early twentieth century, and the core claims put forward by the growing number of nationalists, were still more concerned with the veracity of the historic statehood narrative than they were with the supposed ethnic heritage of Croats.

While the First World War raged, with Croats fighting with the AustroHungarians against the Serbs, the Yugoslavists set up the Yugoslav Committee in London under the leadership of Supilo and Trumbić. ${ }^{111}$ The Yugoslav Committee advocated a federal Yugoslav state and lobbied for the creation of a unified Yugoslavia based on the principle of self-determination later enunciated by Woodrow Wilson in his 'fourteen points'. The reality of the first Yugoslav state, known as the Kingdom of Serbs, Croats and Slovenes, was somewhat different. In place of federalism was monarchical centralism and in place of selfdetermination was the rule of law of the Kingdom of Serbia. The Kingdom of Serbs, Croats and Slovenes was to be ruled by the Serb Royal family, under King Aleksander. ${ }^{112}$

There is some evidence that Croats welcomed the Yugoslav idea, despite the fact that it constituted a major rupture to the historic statehood narrative. The Habsburg commander in Bosnia and Hercegovina, Ekmečić, noted that although loyalty to the Empire remained strong in Slavonia until the end of the war, the war's ending brought a slight majority in favour of Yugoslavism in the rest of the country. Furthermore, Ekmečić noted that the level of support for the Yugoslav idea was greater in Dalmatia. ${ }^{113}$ Leroy King, an American dispatched to Zagreb to gather intelligence at the end of the war, reached a similar conclusion. In 1919 King wrote that, '[t]he vast majority of the Croatians are strongly supporting a united Jugoslavia [sic]'. ${ }^{114}$ Croatian historians tended to dispute this point fiercely. They argued that there may have been a brief period after the collapse of the Habsburg Empire where the Serb alternative was preferable to a feared Italian conquest. However, they argued that by 1919, when it was apparent that the Yugoslav state would be a Serb-dominated entity, there was a great deal of opposition in Croatia to the now mutated idea of Yugoslavia. Stephen Gazi pointed to Stjepan Radić's opposition as indicative of a general Croatian hostility towards the Yugoslav project. ${ }^{115}$ Radić declared that Croats who supported the Yugoslav Committee were acting like 'drunken geese in the fog' ${ }^{116}$ Croatian opposition tended to draw an unhappy comparison between the new Yugoslavism and Croatia's position in the Habsburg Empire. 
Typical of this was a statement by Miroslav Krleža, one of Croatia's most prominent writers, who asserted that:

As a nation, within the framework of the 1918 unification, the Croats have lost all the attributes of their statehood. These attributes, to be sure, were falsely decorative, but nevertheless, in spite of centuries, they were preserved as relics and symbols of a certain liberty, which, through a negation of every democratic liberty, was not entirely devoid of political reality: the crown as the mark of sovereignty, banners, arms, army, autonomy. From any current Croat conservative aspect, it cannot be proved to the Croats that in Austria they did not live in the Kingdom of Croatia, and that they are today not a satrapy, ruled by the most anonymous chiefs of government. ${ }^{117}$

The argument follows that the new state was accepted by Croats made weary by a long war that had left many impoverished. While there was no great mass support for the Yugoslav idea, there was initially a resigned acceptance of the new state, exemplified by the position taken by the Catholic Church, which viewed the state as 'an irreversible development'. ${ }^{118}$ However, because the new kingdom did not reaffirm Croatia's historic statehood, it constituted a major problem for the historic statehood narrative. Croatian nationalist writers therefore tended to make three points to challenge the legitimacy of the new kingdom. First, they argued that most Croats did not support the creation of the new state. Because Croatia was not a democracy and opinion polls were not much used there is no way of testing this claim and Yugoslavist counter-claims.

Second, many writers argued that Yugoslavists in Croatia and abroad were hoodwinked by the Serbs. They argued that this ought to render the kingdom illegitimate. Prior to and during the war, R. W. Seton-Watson had been a leading proponent of the Yugoslav idea. He worked closely with the Yugoslav Committee in London and had secured a considerable amount of access to the British government for them. In a letter to Herbert Fisher in 1918, SetonWatson argued that the Croats were becoming more pro-Yugoslav: "[As] indication of feeling in Croatia, I may mention that a secret meeting was held last year in Fiume [Rijeka] at which a number of priests, Capuchins and Franciscans, representatives of clerical parties and even of the Archbishop of Zagreb himself were present, and means were found to convey to the Jugoslav [sic] committee their approval of its propaganda'. ${ }^{119}$ This positive view changed after the Vidovdan (St Vitus day - the day of ratification) Constitution was promulgated in 1921. In 1921 Seton-Watson lamented that 'the situation in Jugoslavia $[$ sic] reduces me to despair', and stated that, 'I have no confidence in the new constitution, with its absurd centralism'. ${ }^{120}$ According to Seton-Watson the situation continued to deteriorate. In 1923 he wrote that 'the political situation ... is utterly deplorable, for all the most honest and progressive politicians in the country are pare terre and all the scoundrels oben and there is the most complete disorientation and dissatisfaction everywhere'. ${ }^{121}$ The disenchantment of the Croat Yugoslavists is perhaps best captured by Ante Trumbić, one 
of the leading Yugoslavists who, in conversation with the French writer Henri Pozzi, declared that 'the dream of a unified south Slavdom has withered and died in less than sixteen years, and now its corruption stinks across the length and breadth of Europe'. ${ }^{122}$

Third, many writers argued that Croatia's entry into the new kingdom had no legal basis because neither the Croatian Sabor nor the Croatian people gave their consent. The decision to join the kingdom was taken by a special committee rather than by the Sabor as a whole, in sharp distinction to the decisions in 1102 and 1526 it was contended. This line of argument points to the fact that when given the chance to vote, Croats tended to support Croatian nationalist parties rather than pan-Yugoslav parties. In the first elections in 1920, Radićs Croatian Peasants' Party (HSS) swept the board in Croatia, winning nearly 40 per cent of the vote and becoming Croatia's largest party. ${ }^{123}$ Radić changed his manifesto and advocated a federation in which Serbia and Croatia would have a relationship similar to the relationship between Austria and Hungary in the old empire. However, under the new constitution, Belgrade had the right to appoint regional governors and the state apparatus was placed firmly in the hands of the centre. Radić and the HSS responded by withdrawing from the Škupstina (the parliament in Belgrade) and declaring their determination to oppose the constitution.

Between 1920 and the end of the decade, disputes between the kingdom's different nations increased. Croatian historians argued that the illegitimate kingdom was ruining the Croatian economy by restricting its trade with Central Europe and forcing it to pay substantial dues to Belgrade. Typical of this argument is Gazi's calculation that Croatia paid 686 million Dinars more in tax than Serbia did, despite Serbia having a population more than double Croatia's. ${ }^{124}$ The situation worsened still further when, on 14 June 1928, the newspaper Jedinstvo (Unity), which was close to the government, published an open invitation for Radić to be assassinated. ${ }^{125}$ Six days later, Puniša Račić, a Četnik war veteran ${ }^{126}$ crossed the house of the Škupstina and fired a revolver at the group of HSS representatives. Pavle Radić, Stjepan's nephew, was killed instantly and although Stjepan appeared to be recovering from his wounds, he too died on 8 August. ${ }^{127}$ The Archbishop of Zagreb tolled the great bell of Zagreb cathedral - a dignity only normally accorded to deceased bishops - and throughout Croatia the bells of parish churches tolled in mourning. ${ }^{128}$ Radić was buried in Zagreb on 12 August at a funeral that was described as 'resembling more the funeral of a great monarch than of a one-time republican politician', as more than 100,000 people took part in the funeral procession through Zagreb. ${ }^{129}$ The extent of the crisis in Croatia and the threat of civil war prompted the King to summon the new leader of the HSS, Vladko Maček, for talks on the possibility of a peaceful dissolution of the kingdom. ${ }^{130}$

At the beginning of 1929 King Aleksander dissolved the parliament and decreed that he would rule his kingdom directly. Radićs successor, Vladko Maček, initially welcomed this because it signalled the end of the hated Vidovdan 
Constitution, which he had described as a 'badly buttoned vest'. ${ }^{131}$ Maček hoped that the King would accord greater autonomy to Croatia by releasing it from rule by Serbian politicians and he optimistically noted that 'there is no longer a constitution, only a king and a people'. ${ }^{132}$ However, the King banned all nonYugoslav political parties (including the HSS), imprisoned their leaders, changed the name of the kingdom to 'The Kingdom of Yugoslavia', introduced harsh censorship of the press and tolerated no political dissent. ${ }^{133}$ Most critically for the historical statehood narrative, he abolished the former constituent entities (Croatia, Slovenia, Bosnia and Hercegovina, and Serbia) and introduced nine regional Banovine, which bore the names of rivers. The name Croatia was removed from official use for the first time since it was established in the medieval Triune Kingdom. To rub salt into the wounds, Croatia and Dalmatia were again split into two entities. The political situation in Croatia became so bad that it attracted external attention. In 1931 Albert Einstein and Heinrich Mann called upon the rest of Europe to defend the Croats, stating 'all countries are duty bound to shield the small, peaceful and civilised nation of Croatia'. ${ }^{134}$

The political crisis was worsened by the collapse of the European banking system, which impacted heavily on Zagreb because of its close links with Austria and was exacerbated by a series of bad harvests. This prompted a trend towards extremism in Croatian politics and the emergence of both fascist and communist political movements. There was also a marked increase in terrorist activity. The Yugoslav League of Communists (KPJ), the Internal Macedonian Revolutionary Organisation (VMRO) and the infamous fascist Ustaša, though small in size, participated in many acts of bombing and assassination in the 1930s. In 1934, while on a visit to France, King Aleksander was assassinated by a member of VMRO who was aided by the Ustaša. ${ }^{135}$ Fascist Italy was incriminated in the murder, resulting in a Yugoslav-Italian pact in 1937 in which Mussolini agreed to stop supporting the fascist Ustaša (Mussolini had provided it with arms and training camps in Italy) and intern Ante Pavelić, its leader.

By the second half of the 1930s, the HSS had become even more popular under Maček's leadership. Not only did the peasant movement attract the support of its traditional supporters, it also secured a substantial level of support among the Croatian bourgeoisie and intelligentsia. Indeed, by 193540 per cent of the party's representatives were from the middle class. Despite these changes, the party retained its traditional focus as Maček was keen to ensure that the HSS remained a parliamentary movement. It also strongly resisted the Ustaša's violent methods and its membership dwarfed that of the fascists. ${ }^{136}$

The increasing level of support for the HSS and the increasing instability of the international arena prompted the government to reach an agreement with the Croats. In 1939 Maček and the Belgrade government reached a sporazum (agreement) that reorganised the Yugoslav state, awarding substantial autonomy to Croatia. The sporazum created an autonomous Croatian Banovina, which encompassed about 30 per cent of the entire kingdom - including Croatia, Slavonia, Dalmatia, Hercegovina and parts of northeastern Bosnia (Brčko). 
Croatia was to have a separate Ban and the Sabor was to be reinstated. Only foreign policy, transportation and other pan-kingdom areas of administration were to remain in Belgrade and the Sabor would decide everything else. ${ }^{137}$ Some historians believed that the sporazum had the potential to solve the Serb-Croat conflict that had dogged the kingdom since its creation. However, the Axis invasion of Yugoslavia in 1941 meant that its potential was never fulfilled. ${ }^{138}$ Nevertheless, for Croatian historians intent on tracing a continuous line of statehood, the sporazum reasserted the existence of the Croatian state through the reincarnation of the institutions of the Ban and Sabor.

\section{The age of extremes}

Having concluded the sporazum, Prince Paul tried to secure Yugoslavia against the perceived threat from Italy by finally succumbing to German demands for Yugoslavia to join the Axis tripartite pact. ${ }^{139}$ Within Serbia, news of Yugoslavia's agreement with Germany was greeted with mass demonstrations, which provided the signal for those in the army who were opposed to the sporazum to launch a coup against the King. ${ }^{140}$ Winston Churchill commented that Yugoslavia had found its soul and delighted at the creation of a new front against the Germans. ${ }^{141}$ The new front lasted ten days and cost only 166 German troops. ${ }^{142}$ The German occupation ushered in four years of bloodletting in Yugoslavia and drove Croats into one of two extremist movements: the fascist Ustaša led by Ante Pavelić and the communist Partisans led by Tito.

The self-proclaimed leader of the Ustaša,${ }^{143}$ Ante Pavelić, was a Hercegovinian Croat, the son of a building contractor. He believed that he was following in the footsteps of Ante Starčević and the Party of Rights movement. He was the first prominent Croatian nationalist to base his nationalism on ethnic grounds, despite the fact that earlier and contemporary ethnic genealogists had failed to outline a convincing ethnic heritage. Pavelić viewed the Jews and Serbs who had settled in Croatia as agents of Magyarisation who should not have the same rights as Croats. Having studied law at Zagreb University, he was elected municipal councillor in Zagreb. He represented Zagreb in the Škupstina, before founding the Ustaša. Pavelić organised the illegal Ustaša on military lines and advocated an armed struggle for Croatian independence. Until 1937, he received a great deal of support from Mussolini, whose territorial designs on the Dalmatian coast were well known. The Ustaša was based in Italy, from where it launched terrorist attacks in Yugoslavia. However, after the 1937 YugoslavItalian treaty, it was imprisoned in Italy until 1941 when Mussolini installed it as the Croatian government. It is important to note that the Ustaša did not have popular support. Avakumović argues that this was because of its association with Italy and because the HSS was more representative of Croatian opinion. ${ }^{144}$ However, this did not prevent it unleashing an era of terror upon Croatia and Bosnia and Hercegovina. 
Shortly after the German invasion, the infamous Nezavisna Država Hrvatska (Independent State of Croatia - NDH) led by Ante Pavelić was created. The historical controversy of this period is of vital importance to understanding competing claims about the historical statehood narrative in the 1990s. Until the advent of 'Franjoism' in the 1990s (outlined in the following chapter), the narrative tended to avoid the subject of the Ustaša regime altogether. Its partial reinclusion in the 1990s as a legitimate expression of Croatian statehood was a major source of contention between Croats in the 1990s. ${ }^{145}$

The new fascist government issued its first decrees on 17 April 1941. The death penalty was introduced for a range of offences such as abortion. On 26 April the use of Cyrillic (the alphabet used by Serbs) was forbidden and in June and October a whole range of anti-Semitic legislation was passed. The systematic murder of Jews, Serbs, Gypsies and Croatian opponents began immediately. In October 1941 Vladko Maček was arrested and sent to Jasenovac, where a brick factory had been converted into a Croatian Auschwitz. ${ }^{146}$ Maček recalled that:

The camp had previously been a brick-yard and was situated on the embankment of the Sava river. In the middle of the camp stood a two-storey house, originally erected for the offices of the enterprise ... The screams and wails of despair and extreme suffering, the tortured outcries of the victims, broken by intermittent shooting, accompanied all my waking hours and followed me into sleep at night. ${ }^{147}$

Vladimir Dedijer compiled a chilling collection of witness accounts of Ustaša atrocities committed by the NDH regime. One such act was committed at Karitska Jama Gorge, in Bosnia and Hercegovina, which was described by a survivor, Milija Bjelica:

They tried to kill us not with wooden hammers, but shot us by using only two bullets for each group of three. The henchmen placed us in threes, tied back to back at the edge of the gorge ... The shots, which came from close up, were fired into the temples of the ones standing at the sides, and hit the back of the head of the one facing the gorge. Apparently the henchmen did not check to see whether all three were mortally wounded each time, but instead just immediately threw them into the twenty meter deep gorge, causing anyone who was not dead to perish there in torment. ${ }^{148}$

There are many similar, and many more horrific, testimonies of Ustaša atrocities. Under the policy declared by Education Minister, Mile Budak, of deporting a third [of Serbs], converting a third [to Catholicism] and killing a third, the Ustaša terror reached such proportions that some Italian and German fascists complained about the barbarity of the Croats. An observer in the German army noted that, 'even among the Croatians nobody can feel safe in this land anymore ... The Croatian revolution is by far the harshest and most brutal of all the different revolutions that I have been through at more or less close hand since 1918'. ${ }^{149}$

One of the greatest controversies of the Ustaša period was the apparently eager compliance of the Catholic Church. Serbian and communist historians 
tend to argue that the papal regime actively supported the massacre of Orthodox Serbs and provide evidence of priests and Franciscans who actively participated in atrocities. Furthermore, Dedijer argued that Archbishop of Zagreb, Alojzije Stepinac - beatified by the Pope in 1998 - actively supported the Pavelić regime. ${ }^{150}$ The role of Stepinac has become a focal point for different nationalist interpretations of what happened in Croatia between 1941 and 1945. Contrary to the argument that Stepinac actively supported the genocide, many Croatian writers believe that although he supported the cause of Croatian statehood he abhorred the Pavelić regime and helped many people to escape from it.

After the German invasion and the creation of the NDH, Stepinac spoke approvingly of the new regime and in particular of Croatian independence, and met with Pavelić and his deputy, Kvaternik, on 16 April $1941 .{ }^{151}$ However, the wholesale deportation of Jews and Serbs seriously worried him. In a letter to the poglavnik (the leader of the Ustaša) he wrote that:

I am convinced that these things have been happening without your knowledge and that others may not dare to tell you about them ... I hear from many sides that there are instances of inhumane and brutal treatment of non-Aryans during the deportations and at the camps, and even worse that neither old people, children or the sick are spared ... the measures which have been undertaken would have their full effect if they were carried out in a more humane and considerate way, seeing in human beings the image of god. ${ }^{152}$

Stepinac also forwarded to Pavelić a communiqué he had received from Bishop Mišić of Mostar. Mišić's report read:

A reign of terror has come to pass ... men are captured like animals. They are slaughtered, murdered; living men are thrown off cliffs ... From Mostar and Čapljina a train took six carloads of mothers, young girls and children ten years old to the station at Surmanci ... they were led up the mountains and mothers together with their children were thrown alive off precipices. ${ }^{153}$

Marcus Tanner argued that what prevented Stepinac from openly opposing Pavelić was not sympathy for the regime but political naivety. Tanner recorded an instance where Stepinac enquired whether or not the leader knew of the reports of the killing of Serbs. When he was told that, of course, Pavelić knew everything, Stepinac broke down in tears. ${ }^{154}$ However, Stepinac never made a public statement disavowing the NDH, even when he was put on trial by Tito in $1946 .{ }^{155}$

The omission of the Ustaša period from the historical statehood narrative meant that not only have Croatian historians failed to disavow the NDH until recently (and then only partially), they have also - with the exception of Franjo Tuðman (see Chapter 4) - failed to reveal the extent of the opposition to the $\mathrm{NDH}$ within Croatia. Because the imprisoned Maček clung on to the pacifist tradition of the HSS, most Croatian opponents of the Ustaša turned to the communist Partisans under Tito's leadership. By the end of 1943, Croats made up over 30 per cent of a total number of Partisans that exceeded 100,000, meaning that there were more Croatian Partisans than there were Ustaša militia. ${ }^{156}$ 
Controversies about the Second World War are vitally important to the historical statehood narrative. Discussion was severely restricted during the years of Tito's Yugoslavia (1945-1980), and when discussion was permitted this period of history became a highly politicised area of contention. Numbers and culpability play a big part in these debates. It is estimated that the Ustaša killed around 300,000 Serbs, most of Croatia's 36,000 Jews and a large portion of the 200,000 Croats that were killed in the war. These figures were highly contested in the 1990s and these political contests were related directly to different interpretations of the historical statehood narrative.

There are three key areas of debate about the Second World War. The first is the question of whether the $\mathrm{NDH}$ was a legitimate expression of Croatian statehood. It is very difficult to say that it was, while denying that expressions of Croatian national identity have fascist connotations. On the other hand, denying its legitimacy brings the claim of continual statehood into question. Second, there is the question of the level of support enjoyed by the Ustaša. Was Ustaša fascism supported by Croats and their social institutions (the Catholic Church) or was there widespread resistance? Third, did the Ustaša commit genocide against the Serbs or was the killing more indiscriminate and a consequence of the on-going civil war? Of these, the first two questions in particular posed problems in the 1990s when Tuðman tried to unite the different strands of national thinking into a single national movement, as we will see in the following chapter.

\section{Tito's Yugoslavia}

As part of their attempt to eradicate completely all forms of political opposition, the communists hosted a series of show trials similar to those held during the Stalinist purges. The most famous of these show trials were of the Četnik leader, Draža Mihailović, and the Archbishop of Zagreb, Alojzije Stepinac. Mihailović was found guilty of collaboration and was shot in 1946. In the same year, Stepinac was put on trial for colluding with the Ustaša and was sentenced to 16 years in prison. ${ }^{157}$ Throughout Croatia and Serbia anyone suspected of having colluded with either the Četniks or the Ustaša was either imprisoned or executed.

In the first twenty years after the end of the Second World War there was very little by way of a Croatian national movement and no attempt to legitimise the new socialist Yugoslav state in terms of the historical statehood thesis (by arguing that socialist Yugoslavia's federal constitution recognised the sovereignty of the Croatian nation). Instead, the narrative tells us that Croatia had communism imposed on it and finally lost its statehood. Rather than pointing towards continuity, the narrative focuses instead on national opposition to the second Yugoslavia. Maček fled abroad in fear of the communists and never returned to Croatia. ${ }^{158}$ Although Stepinac was released from prison in 1951, he was held in a form of house arrest well away from Zagreb until his death in 
$1960 .{ }^{159}$ By the mid-1960s, however, Croats within the League of Communists began to reassess Croatia's position and began to raise the issue of the need to assert Croatia's historic right to statehood within the Yugoslav federation. In the mid-1960s Croatian communists adopted a strategy of opposing everything that was centralist and Yugoslav. ${ }^{160}$ The main targets for these new Croatian communist leaders were the constitution - which they deemed to be too centralist; democratic centralism - which they believed contradicted the idea of republican democracy; old Partisan communists; and the continuing federal control over foreign currency - the majority of which was earned by Croatia. ${ }^{161}$ These new leaders began to pose as defenders of the Croatian nation against the exploitation of the centre (Belgrade), which was accused of draining off Croatian currency to fund inefficient programmes in the less-developed republics and provinces (southern Serbia, Kosovo, Macedonia and Montenegro). From the mid-1960s onwards, all economic and political issues within the Croatian League of Communists became subsumed within the national question. ${ }^{162}$

The revival of Croatian national consciousness began among intellectuals, with the resuscitation of concern for the cultural questions posed by earlier nationalists. They began questioning the 1954 Novi Sad language agreement, which established a common Serbo-Croatian and equally Croato-Serbian language. ${ }^{163}$ Their opposition took the form of a declaration in 1967, which argued that the Croatian language had been downgraded into a local dialect. ${ }^{164}$ They demanded that Croatian be established as Croatia's official and be used in schools and the state media. ${ }^{165}$ An important centre for this new movement was the reinvigorated Matica Hrvatska. Matica Hrvatska focused on the perceived denigration of Croatian culture. Its journal, Kritika, caricatured Belgrade as a metaphor for the ruthless, bourgeois, backward Serbs who were oppressing the more advanced Croats. Intellectuals argued that this was the only reason why Croatia was not as prosperous as the small nations of Western Europe. ${ }^{166}$ In April 1971 this movement was joined by fascist groups that operated among the large Croatia gasterbeiter (overseas workers) who murdered the Yugoslav ambassador in Stockholm and held a celebration in Munich to celebrate the thirtieth anniversary of the foundation of the $\mathrm{NDH} .{ }^{167}$

The federal government adopted a dual response to the problem of increasing Croatian intransigence. Matica Hrvatska was closed down and many nationalists, including Franjo Tuðman, were jailed. Liberal and nationally minded leaders of the Croatian League of Communists, such as Miko Tripalo and Savko Dabčević-Kučar, were removed from office and replaced by loyal ultra-conservatives such as Stipe Šuvar. Every rank of the party was subjected to the purge and thousands of Croats were expelled, increasing the already disproportionately high relative number of Serbs within the party. The purge, which came to be known as the 'Croatian Spring', crushed every form of political opposition in Croatia. ${ }^{168}$ Hence, for the next twenty years, until the first democratic elections of 1990, Croatia was known as the 'silent republic' because its communist leadership avoided all forms of confrontation at a time in which the 
Slovene party in particular was becoming increasingly liberal, progressive, and nationally minded. ${ }^{169}$

Following Tito's death in 1980, the last ten years of Croatia's membership of Yugoslavia were years of economic and political collapse. More than at any other time in the historical statehood narrative, the discourse was intimately linked with events in Serbia, the rise of Slobodan Milošević in Serbia, the Kosovo question, and anti-Croat propaganda emanating from Belgrade. ${ }^{170}$ In the mid1980s the economy worsened as the national debt increased. In 1986 the Serbian Academy of Arts and Sciences (SANU) released its now infamous Memorandum, which insisted that the Serb nation was threatened by an anti-Serb conspiracy that was being hatched in Croatia, and concluded ominously that '[b] ut for the period of the existence of the NDH, Serbs in Croatia have never been as threatened as they are now'. ${ }^{171}$ In 1987 Slobodan Milošević came to the fore in a visit to the Serbs in Kosovo. He told the Kosovan Serbs that 'no one has the right to beat the [Serb] people' and used nationalist rhetoric to seize control of the Serbian presidency.

On 19 November of the same year, Milošević implied that war would break out if the Serbs in Kosovo did not get their own way. ${ }^{172}$ By the late 1980s, the Serbian nationalist propaganda machine had turned its attentions towards 600,000 Serbs living in Croatia. Belgrade television showed mistreated Serbs and decaying Serb villages that had been neglected by the hateful Croats, and demonstrations in the stronghold of Knin, in the former Vojna Krajina (known today as the Lika region), became regular occurrences.

It was 1989 before the Croats began to respond to this upsurge in Serb nationalism. In February 1989, Franjo Tuðman and a group of others involved in the 'Croatian Spring', illegally formed the Hrvatska Demokratska Zajednica (Croatian Democratic Union - HDZ), the first non-communist or fascist party in Croatia since the demise of the HSS and incarceration of Maček in 1941. The 'Croatian silence' came to an abrupt end in December 1989 when the Croatian League of Communists elected the liberal reformist, Ivica Račan, as party leader. Račan immediately shifted Croatian policy towards Belgrade, and fell in behind the Slovene leadership in their decision to walk out of the party congress of 1990. This decision was made in response to Serb gerrymandering with the federal budget, in which 1.8 billion Dinar (around $\$ 1$ billion) was removed from the Federal Bank reserves and given to the Republic of Serbia. The Croatian League of Communists, again following Slovenia, changed its name (to the DSP) and called Croatia's first free elections.

To guarantee victory, the revamped League of Communists established an electoral system that would ensure that it secured a higher proportion of parliamentary seats than it secured share of the vote. The plan backfired. Most of the 600,000 Serbs in Croatia voted for Serbian parties rather than the reformed communists, who had become more Croatian in outlook. By being all things to all Croats, Tuðman and the HDZ secured large amounts of funding for their campaign. ${ }^{173}$ This funding came largely from Croatian émigrés, organised by the 
future Defence Minister Gojko Šušak. Moreover, there were many other new parties in Croatia, which split the votes that the (former) communists were hoping to secure. The electoral system also conspired against the party, and allowed the HDZ to secure nearly 70 per cent of parliamentary seats with only 40 per cent of the vote. ${ }^{174}$ Franjo Tuðman was elected President of Croatia by the HDZ-dominated Sabor. ${ }^{175}$

Although Tuðman never explicitly called for Croatian independence during the campaign, he made it clear that a future Croatia would function on an independent basis within 'a radically reorganised Yugoslavia'. ${ }^{176}$ It was only after the outbreak of fighting and the intervention of the JNA (Yugoslav People's Army) coupled with the continuing intransigence of the Serb leadership, that a snap referendum on independence was held, after the Serbs blocked the rotation of the federal presidency, which would have put the Croat (and future Croatian President), Stipe Mesić (legally if not practically) at the head of the JNA. Croatian Serbs boycotted the referendum, which produced an overwhelming vote in favour of independence. ${ }^{177}$ On 30 May 1991 Croatia declared its independence from Yugoslavia but had to wait until the beginning of 1992 for recognition. ${ }^{178}$ By that time, the city of Vukovar had been demolished by the Serbs and Dubrovnik had been badly damaged.

\section{Abstract narratives of Croatian identity}

Conceptions of Croatian national identity in the 1990s were framed by the historical statehood narrative with its claim that Croatia has enjoyed continuous statehood since the time of the medieval kingdom. According to Croatian politicians and intellectuals, 'people' become 'Croats' through a perceived shared history of statehood. Unlike the Serbian nation, which found continuity in Orthodox Christianity, Croatian national identity is founded upon statehood and was perpetuated by the continuity of that statehood. ${ }^{179}$ Most writers who articulate the historical narrative claim that the two Yugoslavias were illegitimate because the Sabor had not freely chosen to enter into the union, unlike - it is claimed - the unions with Hungary in 1102 and Austria in 1526. The historical statehood narrative insists that the Croats entered these unions to protect themselves against the Ottomans but that throughout this period Croatia retained a degree of freedom of action that it did not enjoy in the two Yugoslavias. Furthermore, it stresses the separate development of Croats and Serbs, showing that prior to 1918 the two nations had little connection other than a similar language.

As an account of the abstract ways that Croatian national identity is framed, the narrative of historical statehood offers a set of referent points that constitutes and constrains the way that political entrepreneurs at the second level can invoke resonant claims about national identity in order to legitimise particular political programmes. The task now is to address the question of how 
these abstract accounts of Croatian national identity became resonant in the 1990s. Although the historical statehood narrative helps to distinguish Croats from other nationalities and situates them in an albeit contentious continuous political community since the tenth century, it tells us little about the salience or meaning of that identity. While we can accept that the years 1102, 1526 and 1918 provide vital signposts in the thesis of continuous statehood and that it is a shared belief in this legacy of statehood that distinguishes the Croatian nation from others by providing an abstract consciousness, there is nothing in the historical narrative to explain how and why these dates should be so powerful in constituting the modern political consciousness of people calling themselves Croats. The next chapter considers four sets of accounts that attempted to make these abstract ideas of Croatian national identity resonant in the everyday lives of Croats in the 1990s, either by mobilising people behind one or other political programme or by criticising those programmes and the forms of consciousness they tried to construct.

\section{Notes}

1 Address of the President of the Republic of Croatia on the state of the nation at the joint session of both chambers of the Croatian National Parliament, 27 January 1998. Translation issued by Croatian Information Centre, Zagreb, 28 January 1998.

2 Opening statement in Chapter 1 of the Constitution of the Republic of Croatia, 1991. Translated by the Croatian Information Centre, Zagreb.

3 I. Banac The National Question in Yugoslavia: Origins, History, Politics (London: Cornell University Press, 1984), p. 49.

4 See I. Banac, 'Historiography of the countries of Eastern Europe: Yugoslavia', American Historical Review, 97:4 (1992).

5 M. Gross, Počeci moderne Hrvatske. Neoapsolutizam u civilnoj Hrvatskoj i Slavoniji 18501860 (Zagreb: Globus, 1985).

6 See G. W. Hoffman, The Balkans in Transition (London: Van Nostrand Co., 1963), p. 26, and R. L. Wolff, The Balkans in Our Times (Cambridge Mass: Harvard University Press, 1956), p. 31.

7 Banac, The National Question in Yugoslavia, p. 9.

8 M. Tanner, Croatia: A Nation Forged in War (London: Yale University Press, 1997), p. 7.

9 S. Gazi, A History of Croatia (New York: Philosophical Library, 1973), pp. 1 and 12.

10 H. M. V. Emperley, History of Serbia (London: G. Bell and Sons, 1919), p. 12.

11 R. Portal, The Slavs (London: Weidenfield and Nicolson, 1969), p. 1.

12 Portal, The Slavs, p. 14.

13 S. Vladovich, Croatia: The Making of a Nation (Oklahoma: Vladovich Publishing, 1995), p. 4.

14 This is a widely accepted version of events. See, for example, I. Babić, 'Military History', in F. Eterovich and C. Spalatin (eds), Croatia: Land, People, Culture, volume 1 (Toronto: University of Toronto Press, 1970), p. 131; S. Guldescu, 'Political history to 1526', in Eterovich and Spalatin (eds), Croatia: Land, People, Culture, p. 82; and Tanner, Croatia: A Nation Forged in War, p. 9.

15 Guldescu, 'Political history to 1526 ', p. 82.

16 Portal, The Slavs, p. 14. The Carpathian location of the Slavs and their common movement is also accepted by Muriel Heppell. M. Heppell and F. B. Singleton, Yugoslavia 
(London: Ernest Benn Ltd., 1961), p. 31. For a detailed exploration of the movements of the Slavs in this period see J. Fine, The Early Medieval Balkans: A Critical Survey from the Sixth to the Twelfth Century (Ann Arbor: University of Michigan Press, 1983).

17 F. Schevill, A History of the Balkans From the Earliest Times to the Present Day (New York: Dorset Press, 1991), p. 73.

18 Tanner, Croatia: A Nation Forged in War, p. 2.

19 Gazi, A History of Croatia, p. 11.

20 Tanner, Croatia: A Nation Forged in War, p. 3.

21 Gazi, A History of Croatia, p. 11.

22 Hoffman, The Balkans in Transition, p. 26.

23 See Guldescu, 'Political history to 1526', p. 77.

24 Gazi, A History of Croatia, p. 12.

25 G. MacDonald, Area Handbook for Yugoslavia (Washington DC: US Government Printing, 1st edition, 1973), p. 26.

26 V. Markotić, 'Archaeology', in Eterovich and Spalatin (eds), Croatia: Land, People, Culture, p. 64.

27 See the Introduction of A. J. Bellamy, Kosovo and International Society (London: Palgrave-Macmillan, 2002).

28 Constitution of the Republic of Croatia, Chapter 1.

29 H. C. Darby, 'Croatia', in H. C. Darby and R. W. Seton-Watson, A Short History of Yugoslavia from Early Times to 1966 (Cambridge: Cambridge University Press, 1968), p. 23.

30 See MacDonald, Area Handbook for Yugoslavia, p. 29, and J. R. Lampe, Yugoslavia as History: Twice There Was a Country (Cambridge: Cambridge University Press, 1996), p. 14.

31 Tanner, Croatia: A Nation Forged in War, p. 9.

32 See Darby, 'Croatia', p. 24.

33 Recorded by Guldescu, 'Political history to 1526', p. 94.

34 S. Vladovich, Croatia: The Making of a Nation, p. 10.

35 See J. Borošak-Marijanović, Croatian Flags Through the Centuries (Zagreb: Hrvatski Povijesni Muzej, 1996); A. J. Bellamy, 'Reclaiming the Croatian Flag', Rethinking History, 3:3 (1999); S. Granić, 'The Croatian Coat of arms: historical emblem or controversial symbol?', Journal of Croatian Studies, 24-5 (1993-94).

36 I am grateful to the Croatian National Mint for this information.

37 The controversy over the use of Croatian symbols, which later became associated with fascism, will be discussed at greater length in the following chapters. On the origin of the symbols see Guldescu, 'Political history to 1526', p. 96.

38 Guldescu, 'Political History to 1526', pp. 98-100 and Vladovich, Croatia: The Making of a Nation, p. 12.

39 Guldescu, 'Political history to 1526', p. 103.

40 Guldescu, 'Political history to 1526', p. 103.

41 E. M. Despalatović, Ljudevit Gaj and the Illyrian Movement (London: Moulton and Co., 1975), p. 10.

42 Banac, The National Question in Yugoslavia, p. 12.

43 F. R. Preveden, A History of the Croatian People, volume 2 (New York: Philosophical Library, 1962), p. 87.

44 S. Guldescu, History of Medieval Croatia to 1526 (The Hague: Moulton and Co., 1964), p. 306.

45 Guldescu, History of Medieval Croatia, p. 316.

46 Gazi, A History of Croatia, p. 54.

47 B. M. Janković, The Balkans in International Relations (London: Macmillan, 1988), p. 29.

48 Janković, The Balkans, p. 29.

49 The Magyar version of events is widely expressed in the literature. Roger Portal notes that the Hungarians 'conquered' Croatia, Portal, The Slavs, p. 96; As do, Anon, Jugoslavia: 
Vol. II: History, Peoples, Administration (London: Naval Intelligence Division Handbook Series, 1944), p. 16, and Hoffman, The Balkans in Transition, p. 44.

50 Guldescu, 'Political history to 1526', p. 104.

51 Guldescu, History of Medieval Croatia, p. 180.

52 Croatian Sabor Pragmatic Sanction of 11 March 1712. Cited by Gazi, A History of Croatia, p. 114.

53 Constitution of the Republic of Croatia.

54 C. A. Maccartney, Hungary and her Successors (Oxford: Oxford University Press, 1937), p. 357.

55 Gazi, A History of Croatia, p. 93.

56 S. Guldescu, 'Croatian political history 1526-1918', in F. Eterovich and C. Spalatin, Croatia: Land, People, Culture, volume 2 (Toronto: University of Toronto Press, 1970), p. 5.

57 Gazi, A History of Croatia, p. 94.

58 Sabor declaration cited by Gazi, A History of Croatia, p. 95.

59 Guldescu, 'Croatian political history 1526-1918', p. 7.

60 Heppell and Singleton, Yugoslavia, p. 93.

61 See Anon, Jugoslavia: Vol. II, p. 20.

62 See Z. Zlatar, Between the Double Eagle and the Crescent (New York: East European Monographs No. 348, 1992).

63 Lampe, Yugoslavia as History, pp. 27 and 29.

64 Lampe, Yugoslavia as History, p. 29.

65 Guldescu, 'Political history 1526-1918', p. 16. For an extended account of the establishment of the military frontier and the politics surrounding its existence see G. E. Rothenberg, The Military Border in Croatia: A Study of an Imperial Institution (London: University of Chicago Press, 1966).

66 Gazi, A History of Croatia, p. 105.

67 B. Jelavich, History of the Balkans: Eighteenth and Nineteenth Centuries, volume 1 (Cambridge: Cambridge University Press, 1983), p. 156.

68 Guldescu, 'Croatian political history 1526-1918', p. 9, and C. Bracewell, The Uskoks of Senj: Piracy, Banditry and Holy War in the Sixteenth-Century Adriatic (London: Cornell University Press, 1992), pp. 29-30.

69 MacDonald, Area Handbook for Yugoslavia, p. 30.

70 See Tanner, Croatia: A Nation Forged in War, p. 72.

71 Gazi, A History of Croatia, p. 124.

72 Gazi, A History of Croatia, p. 133.

73 See Gazi, A History of Croatia, pp. 125-6, and Lampe, Yugoslavia as History, p. 42.

74 Arguments taken from Anon, Jugoslavia: Vol. II, pp. 22-4.

75 R. A. Kann, The Multinational Empire: Nationalism and National Reform in the Habsburg Monarchy 1848-1918 (New York: Columbia University Press, 1950), p. 244.

76 Guldescu, 'Croatian political history 1526-1918', p. 37.

77 See Tanner, Croatia: A Nation Forged in War, p. 72.

78 For an exhaustive account of Kossuth's political ambitions see O. Zarek, Kossuth (London: Selwyn and Blount, 1942). A more general account of the rise of Magyar nationalism in the early nineteenth century is offered by C. A. Maccartney, Hungary: A Short History (Edinburgh: Edinburgh University Press, 1962).

79 Guldescu, 'Croatian political history 1526-1918', p. 41, and Anon, Jugoslavia: Vol. II, p. 26.

80 Tanner, Croatia: A Nation Forged in War, p. 91.

81 Cited by Anon, Jugoslavia: Vol. II, p. 27.

82 For details of the Nagodba see Gazi, A History of Croatia, pp. 150-5; Guldescu, 'Croatian political history 1526-1918', pp. 46-50; and I. Omrčanin, Diplomatic and Political History of Croatia (Philadelphia: Dorrance, 1972).

83 See Guldescu, 'Croatian political history 1526-1918', pp. 46-50. 
84 Gazi, A History of Croatia, pp. 166-7.

85 Banac, The National Question in Yugoslavia, p. 75.

86 F. Trogrančić, 'Literature 1400-1835', in F. Eterovich and C. Spalatin (eds), Croatia: Land, People, Culture, volume 1 (Toronto: University of Toronto Press), p. 238.

87 Lampe, Yugoslavia as History, p. 42.

88 Lampe, Yugoslavia as History, p. 44. The linguistic impact of the Illyrian movement is exhaustively outlined in G. Thomas, The Impact of the Illyrian Movement on the Croatian Lexicon (Munich: O. Sagner, 1988).

89 Cited and translated by Despalatović, Ljudevit Gaj, p. 41.

90 Portal, The Slavs, p. 365.

91 Gazi, A History of Croatia, p. 137.

92 R. W. Seton-Watson, The Southern Slav Question (London: G. Bell and Sons, 1911), p. 128.

93 Seton-Watson, The Southern Slav Question, p. 160.

94 Seton-Watson, The Southern Slav Question, p. 160.

95 Tanner, Croatia: A Nation Forged in War, p. 101.

96 Josip Strossmayer, cited by Tanner, Croatia: A Nation Forged in War, p. 101.

97 Banac, The National Question in Yugoslavia, p. 90.

98 See Guldescu, 'Croatian political history 1526-1918', p. 39, and Gazi, A History of Croatia, p. 140.

99 M. Gross, 'Croatian national-integrational ideologies from the end of Illyrism to the creation of Yugoslavia', Austrian History Yearbook, 15-16 (1979), 3.

100 Gross, 'Croatian national-integrational ideologies', 3-15.

101 Guldescu, 'Croatian political history 1526-1918', p. 44.

102 M. Biondich, 'Stjepan Radić, Yugoslavism, and the Habsburg Monarchy', Austrian History Yearbook, 27 (1996), 113.

103 Biondich, 'Stjepan Radić', 45.

104 Lampe, Yugoslavia as History, p. 60.

105 Banac, The National Question in Yugoslavia, p. 86.

106 For a detailed analysis of the life and political career of Stjepan Radić see S. Gazi, 'Stjepan Radić: his life and political activities 1871-1928', Journal of Croatian Studies, 14-15 (1973-74). On the origins of the HSS see S. Gazi, 'Beginning of the Croatian Peasant Party: A historico-political study', Journal of Croatian Studies, 3-4 (1962-63).

107 Banac, The National Question in Yugoslavia, p. 104.

108 Banac, The National Question in Yugoslavia, p. 104.

109 For a more detailed insight into the pre-First World War policies of the Radić brothers see Biondich, 'Stjepan Radić', 118-31.

110 See Gazi, A History of Croatia, p. 192.

111 On the role of Croatia in the First World War see I. Omrčanin, Military History of Croatia (Philadelphia: Dorrance, 1984).

112 For detailed accounts of the negotiations that led to the formation of the Kingdom of Serbs, Croats and Slovenes see D. R. Živojinović, America, Italy and the Birth of Yugoslavia: 1917-1919 (London: Columbia University Press, 1979), and I. J. Lederer, Yugoslavia at the Paris Peace Conference (London: Yale University Press, 1963).

113 See V. Ekmečić, 'Serbian War Aims', in D. Djordjević, The First Yugoslavia: The Search for a Viable Political System (Santa Barbara: ABC -Clio, 1980), pp. 25-6.

114 See Tanner, Croatia: A Nation Forged in War, p. 120.

115 Gazi, 'Beginning of the Croatian Peasant Party', 324.

116 Tanner, Croatia: A Nation Forged in War, p. 278.

117 Miroslav Krleža, 1933, cited by Banac, The National Question in Yugoslavia, p. 260.

118 Banac, The National Question in Yugoslavia, p. 419. There were, however, outbreaks of violence against the new state. See I. Banac, 'Emperor Karl has become a Comitadji: the Croatian disturbances of 1918', Slavonic and East European Review, 70:2 (1992). 
119 R. W. Seton-Watson - letter to Herbert Fisher, 9 October 1918. H. Seton-Watson (ed.), R. W. Seton-Watson and the Yugoslavs: Correspondence 1906-1941, volume 1 (London: British Academy, 1976), p. 28.

120 R. W. Seton-Watson - letter to Milan Čurčin, 2 December 1921. Hugh Seton-Watson (ed.), R.W. Seton-Watson and the Yugoslavs: Correspondence 1906-1941, volume 2 (London: British Academy, 1976), p. 97.

121 R. W. Seton-Watson - letter to May Seton-Watson, 15 April 1923. Seton-Watson (ed.), R. W. Seton-Watson and the Yugoslavs, volume 2, p. 102.

122 Ante Trumbić in conversation with Henri Pozzi. H. Pozzi, The Black Hand Over Europe, reprint of the 1935 edition (Zagreb: Croatian Information Centre, 1994), p. 24.

123 A full breakdown of the 1920 election result is provided by Lampe, Yugoslavia as History, p. 121. The HSS won 50 seats, with the second largest party in Croatia - the Democrats winning 19 seats.

124 Gazi, A History of Croatia, p. 304. Gazi does not reveal the source of his calculation, saying only that by 1928 'it was known that ...'.

125 See the quote in Tanner, Croatia: A Nation Forged in War, p. 123

126 The Cetnici were Serb royalist fighters in the First World War.

127 The story of the Škupstina murders is found in the same form in all the works on Yugoslav history of this period. The best accounts of the actual event can be found in Lampe, Yugoslavia as History, p. 158; R. W. Seton-Watson and R. G. D. Laffan, 'Yugoslavia between the wars', in H. C. Darby and R. W. Seton-Watson, A Short History of Yugoslavia from Early Times to 1966 (Cambridge: Cambridge University Press, 1968), p. 174; and Gazi, A History of Croatia, p. 305. On the background and consequences of the event see Tanner, Croatia: A Nation Forged in War, pp. 124-9.

128 Tanner, Croatia: A Nation Forged in War, p. 124. Tanner cites R. Horvat on this point.

129 Tanner, Croatia: A Nation Forged in War, p. 124.

130 L. J. Cohen, Broken Bonds: Yugoslavia's Disintegration and Balkan Politics in Transition, 2nd edition (Oxford: Westview, 1995), p. 16.

131 Lampe, Yugoslavia as History, p. 161.

132 Maček is cited by Seton-Watson and Laffan, 'Yugoslavia between the wars', p. 174.

133 See Seton-Watson and Laffan, 'Yugoslavia between the wars', p. 174 and Gazi, A History of Croatia, p. 309.

134 This statement is widely reported. This citation is taken from Vladovich, Croatia: The Making of a Nation, p. 44.

135 See Lampe, Yugoslavia as History, p. 170-3; M. Almond, Europe's Backyard War: The War in the Balkans (London: Mandarin, 1994), p. 125; and S. Graham, Alexander of Yugoslavia: The Story of the King who was Murdered in Marseilles (New Haven: Yale University Press, 1939).

136 I. Avakumović, 'Yugoslavia's fascist movements', in P. F. Sugar (ed.), Native Fascism in the Successor States: 1918-1945 (Santa Barbara: ABC-Clio, 1971), p. 140. Also see S. Trifković, 'The first Yugoslavia and origins of Croatian separatism', East European Quarterly, 26:3 (1992).

137 See Tanner, Croatia: A Nation Forged in War, pp. 132-5; Lampe, Yugoslavia as History, pp. 191-2; Seton-Watson and Laffan, 'Yugoslavia between the wars', p. 197; and Gazi, A History of Croatia, pp. 326-7.

138 G. F. Vrbanić, The Failure to Save the First Yugoslavia: The Serbo-Croatian Sporazum of 1939 (Chicago: Ziral, 1991), p. 37.

139 H. Seton-Watson, Eastern Europe Between the Wars 1918-1941 (Cambridge: Cambridge University Press, 1946), p. 152.

140 S. Trifković, 'Yugoslavia in crisis: Europe and the Croat question, 1939-41', European History Quarterly, 23 (1993), 547-50.

141 W. R. Roberts, Tito, Mihailović and the Allies 1941-45 (New Jersey: Rugters University Press, 1973), pp. 11-14. 
142 M. C. Wheeler, Britain and the War for Yugoslavia 1940-43 (New York, Columbia University Press, 1980) p. 59. Also see M. C. Wheeler, 'White eagles and white guards: British perceptions of anti-communist insurgency in Yugoslavia in 1945', Slavonic and East European Review, 66 (1998).

143 Ustaša means uprising - an Ustaši is one who participates in an uprising.

144 The background on Pavelić and discussion of the lack of support for fascism is taken from Avakumović, 'Yugoslavia's Fascist Movements', pp. 139-41.

145 Writers within the Croatian diaspora have been particularly keen to rehabilitate the NDH. For example, see S. Hefer, Croatian Struggle for Freedom and Statehood (Buenos Aires: Croatian Information Service, 1956).

146 Jasenovac was undoubtedly the most renowned death camp in the NDH, which continues to inspire controversy today. See L. Boban, 'Jasenovac and the manipulation of history', East European Politics and Societies, 4:3 (1990); L. Boban, 'Still more balance on Jasenovac and the manipulation of history', East European Politics and Societies, 6:4 (1992); M. Bulajić, Tudjman's 'Jasenovac Myth' Ustaša Crimes of Genocide (Belgrade: Ministry of Information of the Republic of Serbia, 1992); and R. M. Hayden, 'Balancing discussion of Jasenovac and the manipulation of history', East European Politics and Societies, 6:4 (1992).

147 J. Steinberg, 'Types of genocide? Croatians, Serbs and Jews, 1941-5', in D. Cesarani (ed.), The Final Solution: Origins and Implementation (London: Routledge, 1994), p. 176.

148 Testimony of Milija Bjelica in V. Dedijer, The Yugoslav Auschwitz and the Vatican: The Croatian Massacre of the Serbs During World War II (New York: Prometheus Books, 1992), p. 160.

149 Steinberg, 'Types of genocide?', p. 181.

150 Dedijer, The Yugoslav Auschwitz and the Vatican.

151 Lampe, Yugoslavia as History, p. 205.

152 Cited by S. Alexander, The Triple Myth: A life of Archbishop Alojzije Stepinac (New York: East European Monographs, 1987), pp. 71-2.

153 Alexander, The Triple Myth, p. 80.

154 Tanner, Croatia: A Nation Forged in War, pp. 155-6.

155 Lampe, Yugoslavia as History, p. 218.

156 It is estimated by John Lampe that the entire NDH regime - including officers and bureaucratic officials - never exceeded 50,000 people, of which less than 30,000 were part of the militia - according to Mark Almond. See Lampe, Yugoslavia as History, p. 219 and Almond, Europe's Backyard War, p. 137.

157 A thorough narrative of the trial, which makes extensive use of primary documentation is provided by S. Alexander, Church and State in Yugoslavia Since 1945 (Cambridge: Cambridge University Press, 1979), Chapter 3.

158 Tanner, Croatia: A Nation Forged in War, p. 174.

159 Tanner, Croatia: A Nation Forged in War, p. 186.

160 S. K. Pavlowitch, The Improbable Survivor: Yugoslavia and its Problems 1918-1988 (Columbus: Ohio State University Press, 1989), p. 25.

161 D. Rusinow, The Yugoslav Experiment: 1948-74 (London: C. Hurst and Co. for the Royal Institute of International Affairs), pp. 248-9.

162 Rusinow, The Yugoslav Experiment, pp. 248-9.

163 The language question will be addressed in greater detail in Chapter 6. Details on the 1954 Novi Sad agreement and the 1967 declaration are taken from B. Franolić, Language Policy in Yugoslavia With Special Reference to Croatian (Paris: Nouvelles Editions Latines, 1988). It is worthy of note that this edition was presented to the Hugh Owen Library at the University of Wales, Aberystwyth by the Croatian Peasants' Party (HSS). Also see A. N. Luk, 'The linguistic aspect of ethnic conflict in Yugoslavia', in P. Akhavan and R. Howse (eds), Yugoslavia: The Former and Future (Washington DC: The Brookings Institute, 1995). 
164 Franolić, Language Policy in Yugoslavia, p. 16.

165 Franolić, Language Policy in Yugoslavia, p. 16.

166 Rusinow, The Yugoslav Experiment, p. 250.

167 Rusinow, The Yugoslav Experiment, p. 250.

168 On the 'Croatian Spring' see A. Čuvalo, The Croatian National Movement 1966-72 (New York: Columbia University Press, 1990); A. Cuvalo, 'Croatian nationalism and the Croatian national movement (1966-1972) in Anglo-American publications - a critical assessment', Journal of Croatian Studies, 30 (1989); and M. Veselica, The Croatian National Question: Yugoslavia's Achilles' Heel (London: United Publishers, 1981).

169 See Tanner, Croatia: A Nation Forged in War, pp. 196-202.

170 There was an immense amount of literature equating all forms of Croatian national expression with Ustaša fascism and inciting fear and hatred among the Croatian Serbs. See, for example, S. Kljakić, A Conspiracy of Silence: Genocide in the NDH and the Concentration Camp Jasenovac (Belgrade: Ministry of Information of the Republic of Serbia, 1991); R. Petrović, The Extermination of the Serbs on the Territory of Croatia (Belgrade: Ministry of Information of the Republic of Serbia, 1991); E. Paris, Genocide in Satellite Croatia: A Record of Racial and Religious Persecutions and Massacres (Melbourne: Srpska Misao, 1981); and Serbian Academy of Arts and Sciences (SANU), Some Basic Facts About the Position of Serbian People in Croatia (Belgrade: SANU, 1991).

171 SANU, Some Basic Facts, p. 1.

172 Tanner, Croatia: A Nation Forged in War, p. 216.

173 See V. V. Godina, 'The outbreak of nationalism on former Yugoslav territory: a historical perspective on the problem of supranational identity', Nations and Nationalism, 4:3 (1998).

174 For a detailed breakdown of the 1990 elections see I. Siber (ed.), The 1990/93 Sabor Elections in Croatia: Analysis, Documents and Data (Berlin: Edition Sigma, 1997).

175 See I. Grdešić, '1990 Elections in Croatia', Croatian Political Sciences Review, 1:1 (1992), pp. 97-9.

176 C. Cviić, 'Croatia', in D. A. Dyker and I. Vejvoda (eds), Yugoslavia and After: A Study in Fragmentation, Despair and Rebirth (London: Longman, 1996), p. 206.

17793.2 per cent voted in favour of a 'sovereign and independent Croatia'. Vladovich, Croatia: The Making of a Nation, p. 214. On the Serb problem, see B. Kovačević, 'A view on the proposals for the solution of the Serb question in Croatia', Gaudeamus, 4 (1991).

178 The intricacies of the dissolution of Yugoslavia have been well documented elsewhere. On the specificities on the referendum, declaration and eventual recognition see L. J. Cohen, 'The disintegration of Yugoslavia', Current History, 91:568 (1992); and A. James, 'The UN in Croatia: An exercise in futility', World Today, 49:5 (1993). For views on the recognition debate see N. S. Dokić, 'The international community and the case of Croatia and Slovenia', International Spectator, 27:4 (1992); J. Gow, Legitimacy and the Military: The Yugoslav Crisis (London: Pinter, 1992); and C. C. Hodge, 'Botching the Balkans: Germany and the recognition of Slovenia and Croatia', Ethics and International Affairs, 12 (1998).

179 See D. N. Šuljak, Croatia's Struggle for Independence: A Documentary History (Arcadia California: Croatian Information Service, 1977) and S. M. Vujica, Croatia's Struggle for Independence (New York: Croatian National Council in Exile, 1965). 


\section{4}

\section{Contemporary accounts of Croatian national identity}

According to Benedict Anderson, 'communities are to be distinguished, not by their falsity/genuineness, but by the style in which they are imagined'. ${ }^{1}$ This chapter investigates how the Croatian nation was imagined in the 1990s. It focuses on four sets of accounts that attempted to provide contemporary resonance to the abstract frames of national identity discussed in the previous chapter. These accounts attempted to either interpret what it meant to be Croatian in order to secure support for a political programme, or - as in the case of the dissident intellectuals - to challenge such accounts. However, they all attempted to give resonance to abstract ideas in the contemporary context. After a discussion of the so-called 'Franjoist' narrative offered by President Franjo Tuðman and his party, I will discuss alternative conceptions of identity that were articulated by opposition parties, dissident intellectuals and the Croatian diaspora. I argue that each of these 'political entrepreneurs' drew upon, and offered interpretations of, the historical statehood thesis in order to legitimise their programmes or to challenge the manifestos of others. The abstract frames discussed in the previous chapter therefore presented common frames of reference with which to seek legitimacy for political practices or to use to question that legitimacy.

One of the central themes of this chapter is that different accounts of national identity (which draw upon a common stock of narrative or makes use of similar 'frames') inform political discourse and compete with each other. As Michael Billig argued:

Different factions, whether classes, religions, genders or ethnicities, always struggle for the power to speak for the nation, and to present their particular voice as the voice of the national whole, defining the history of other sub-sections accordingly. 'The voice of the nation' is a fiction ... Thus, national histories are continually being re-written, and the re-writing reflects current balances of hegemony. ${ }^{2}$ 
These narratives of national identity should be seen as a political battleground. Ideas about national identity provide a framework for political discourse. In the case of a nation that has only recently achieved statehood, issues of state politics are 'nationalised' and particular rules of engagement are developed.

\section{The dominant narrative: HDZ and 'Franjoism'}

HDZ - zna se - was the most oft-used election slogan of Tuðman's party, the HDZ. Zna se means 'of course', 'it is normal' or 'it is so', and thus the slogan called the reader to equate the Croatian nation with the HDZ, because 'it is so'. This linking of the HDZ with Croatia was a recurrent theme in the party's rhetoric. For example, the Sahovnica coat of arms became both the symbol of the HDZ and the state's flag. In a speech to the party faithful in which Tuðman identified the main threats to the political well-being of his party, he expressed alarm at the 'teaming-up of the internal and external opponents of the HDZ and of independent Croatia'. ${ }^{3}$ Thus, opponents of the HDZ were also viewed as the enemies of Croatia. This linkage extended into the lexicon of political science. The Croatian Political Dictionary contained entries for 'snake in bosom' (opponents of Croatia and Tuðman), 'Croatian Communist Gulag', 'Falian strategy of Tuðman the warrior' (taking up three pages) and 'best' (describing this as the HDZ). ${ }^{4}$ A reviewer in the Feral Tribune noted the exclusions from the new Croatian political lexicography. The words 'fascism', 'antifascism', 'Ustaša' and 'Ante Pavelić' were not to be found. 'Tuðman, the good shepherd of the Croatian nation, also became its most significant historical figure. In a book of Croatian 'heroes' published by the Ministry of Defence, the medieval kings received three pages between them, Starčević received eight pages, Radić received nine pages and Tuðman received thirty-two. ${ }^{6}$ The linkage between party, president and state was a deliberate policy that formed the cornerstone of the HDZ project in the 1990s.

Franjo Tuðman described himself as a 'Croatian historian, politician and statesman'. ' He was born in 1922 north of Zagreb, in the same district that Tito was born in. His parents were Radić supporters and when the Second World War broke out he joined Tito's communist Partisans. After the war, he rose to the position of Major-General in the JNA. He wrote his doctoral thesis on the causes of the 1941 uprising in Belgrade and in 1961 decided to leave the army in order to focus on historical research. He was later appointed Director of the Institute for the History of the Workers Movement in Croatia. ${ }^{8}$ In December 1971 he was arrested and sentenced to two years' imprisonment for 'maliciously misrepresenting the socio-political situation in Croatia'. In February 1981 he was imprisoned again, on similar charges, for three years. ${ }^{9}$ In a letter to the United States Congress, Tuðman recalled that he fought Nazism in the Second World War, losing his brother in 1943, that his parents were killed by the Partisans in 1946 and that he was jailed for his 'anti-totalitarian political views'. ${ }^{10}$ 
According to David Owen, who negotiated with Tuðman when he was acting as a UN envoy, 'Tudjman's [ sic] nationalism is worn openly on his sleeve, his soldiers know that he is ready himself to fight for Croatia ... Unlike Milosevic [sic] who is a pragmatist, Tudjman [sic] is an opportunist in the cause of Croatia'. 'Jovan Rasković, founder of the Serbian Democratic Party in the socalled Krajina, held a similar view. He stated, 'he is a tough politician of clear conceptions who represents what most Croats accept. Tudjman [sic] is the kind of character who speaks quite openly about his intentions'. Rasković also described the President of Croatia as 'Croat-centric' but not Ustaša. ${ }^{12}$

To sell the HDZ's vision of a unified and independent Croatia, Tuðman established a political movement in which he embodied the Croatian nation, through the ideology of 'Franjoism'. ${ }^{13}$ Franjoism held that the extremes of Croatian political ideology - from fascism to communism - could be represented and expressed in the person of Franjo Tuðman. ${ }^{14}$ Tuðman argued that the transition from a communist system to independent and democratic statehood could only be achieved if these cleavages were bridged. The programme of 'national reconciliation' involved instigating co-operation between first generation descendants of Partisan and Ustaša supporters. Tuðman believed that he could personally bridge the gap between the fascists and communists. Not only did 'Franjoism' include a commitment to unite the 'bright and dark chapters of Croatia's past' it also sought to bring Croats living in Croatia together with those living abroad. ${ }^{15}$ As one commentator suggested, for Tuðman, Franjoism meant that he was 'the president of all Croats'. ${ }^{16}$

The HDZ saw itself as a national movement rather than a political party in the normal sense. Tuðman argued that:

Unlike all the political parties present until that moment [the formation of the HDZ] and based on neither class or ideological-political (middle-class, peasant, workers, Christian, liberal, socialist) differences, the HDZ appeared as a nationwide democratic party focused on bringing together all nation-building forces in all layers and classes of society, from the radical right through the moderate position to the revolutionary left. ${ }^{17}$

Tuðman saw himself as the personification of Croatian unity - through him national cleavages would be overcome. He tried to foster that unity through his party. The HDZ was founded illegally in June 1989 and announced its first political programme in 1990. It announced that it would be a pan-Croatian movement that would mobilise the entire nation by unifying the diverse strands of its political traditions. The rallying call for this mobilisation was the fight for Croatian sovereignty. The attainment of sovereignty was the self-declared reason for the HDZ's existence and some argued that sovereignty and national independence remained its only substantive interest throughout the decade. ${ }^{18}$

The goal of a united Croatian national identity required particular policy and rhetorical orientations. Tuðman had to establish a unified narrative of the 'centuries-old dream' of Croatian statehood by arguing that the different 
thinkers and politicians (discussed in the previous chapter) all shared that dream even if they disagreed about the most desirable type of state. In 1981 he wrote that 'from medieval times the Croatian nation has preserved its national-state individuality, which has been encroached upon in the Habsburg monarchy, but never shattered ${ }^{19}$ and continued by arguing that the wealth and diversity of Croatian historical and national literature could be reduced to a national aspiration 'for centuries to realise its full national independence'. ${ }^{20}$ Tuðman found no problem with unifying the Illyrianist ideas of Gaj and Strossmayer with the socialist-confederalist ideology of Radić, the nationalism of Starčević and the fascism of Pavelić. In each, he simply saw a desire for Croatian statehood.

Tuðman's first move was to unify the writings and actions of Croatia's historical figures by identifying them as 'Croats' and seeing diverse political agendas as products of a shared dream for Croatian statehood. The fact that Strossmayer favoured pan-Slavism and Radić initially favoured trialism within the Habsburg monarchy eluded Tuðman, and he felt adequately qualified to situate Radić the pacifist as having the same yearning as Pavelić the fascist murderer, despite the fact that Radićs successor, Vladko Maček had been imprisoned by the Ustaša at the Jasenovac death camp. None of this was problematic for Tuðman. All Croats could rally behind Franjoism, the argument went, because it encompassed every strand of Croatian political thought.

Tuðman attempted to unify the Croatian people by situating them alongside an 'other', the Serbs. He contended that this otherness was constituted on three planes - cultural, historical, and geographical. In the cultural realm he argued that Croats had culture while Serbs did not. For example, contemporary folk music was exiled from Croatian media not only because of its supposed 'low cultural quality' but also because of the belief that such songs 'belong exclusively to the Serbian (un)cultural identity'. ${ }^{21}$ There can be little doubt that Tuðman supported such purification of Croatian culture, given his view that Croatian and Serbian cultures were completely different. He told an interviewer in New York in 1992 that:

Croats belong to a different culture - a different civilization from the Serbs. Croats are part of Western Europe, part of the Mediterranean tradition. Long before Shakespeare and Moliere, our writers were translated into European languages. The Serbs belong to the East. They are Eastern peoples like the Turks and Albanians. They belong to the Byzantine culture ... despite similarities in language we cannot be together. ${ }^{22}$

Tuðman insisted that this inherent cultural difference was created by the two nations' divergent histories. In bringing them together in the Kingdom of Serbs, Croats and Slovenes in 1918, the 'Versailles powers' (as Tuðman called them) forced together two nations that had experienced completely separate histories since the east-west schism of AD 395. This schism produced two nations that were different in their national consciousness, cultural make-up and 'general historical, state-political and religious tradition' ${ }^{23}$ Croatia and Serbia were also geopolitically separate, he argued. Croatia was at the heart of Europe, both 
geographically and politically. Drawing one of his many historical comparisons, Tuðman recalled that 'at the time of the Ottoman invasion upon Christian Europe, plundered Croatia received recognition as the antemurale christianitatis. Today, still defending freedom and democracy, she remains the bulwark of European democracy against attempts at restoration Communism'. ${ }^{24}$ Simply put, in a phraseology that Tuðman used on many occasions, the difference between Serbs and Croats was not the ordinary difference between two nations. Instead, it was a difference of civilisations. Croats were European while Serbs were Balkan. Thus all Croats could rally behind 'Franjoism' because they were united in not being Serb, Balkan or uncivilised.

The discourse of national unity required a narrative of Croatian history that could bind Croats living in Croatia with those living abroad, many of whom had connections with the Ustaša. This included an account of the oppression of Croatia by Yugoslavia and a tentative rehabilitation of the Pavelić regime into the historical narrative. In a discussion in 1991 with the American ambassador to Yugoslavia, Warren Zimmerman, Tuðman succinctly recounted an account of Yugoslav Croatia that sought to bind Croats together through a story of common suffering. He recalled that:

45 years of communist rule have destroyed the moral values of Croatian society. People don't know how to accept responsibility for their own future. The one-party system has created disillusions everywhere. The best people have left. Corruption has become a way of life. The idea of Yugoslavia has been a negative influence ... to us Croats, Yugoslavia was built on an illusion. ${ }^{25}$

For Tuðman, Yugoslavia, communism and union with Serbia caused a moral decline in Croatia. Furthermore, he believed that Yugoslavia was responsible for the economic, social and even demographic problems confronting Croatia. ${ }^{26}$ These problems impacted on all Croats and united them in suffering.

The main obstacle to uniting indigenous and émigré Croats was the connection that many émigrés had to the fascist regime of 1941-45. The reintegration of émigré Croats therefore proved to be one of the most controversial issues in Croatian politics in the 1990s. Some observers suggested that attempts to rehabilitate the émigrés owed more to the desire to secure important funding from North America, Latin America, Germany and Australia than to an ideological yearning for the uniting of the Croatian nation. ${ }^{27}$ According to Mark Thompson, these groups contributed $\$ 8.2$ million to the cause, giving the HDZ a substantial edge in funding over the other parties. ${ }^{28}$ One of the most prominent returning émigrés was Gojko Šušak, a Toronto based Croat originally from Hercegovina. Described in the Croatian independent press as the 'pizza man', he had made his living as a decorator. Though not possessing great wealth himself, he was instrumental in securing large amounts of money for the HDZ through its offices in North America. ${ }^{29}$ After returning to Croatia, Šušak was appointed Minister of Defence where he gained a reputation as a hard-line nationalist on the right wing of the HDZ. ${ }^{30}$ 
The policy of uniting émigré and indigenous Croats contained three principal elements. First, Tuðman argued that the Serbs exaggerated the scale of the Ustaša genocide in the Second World War. Second, he insisted that the NDH state was a legitimate manifestation of Croatia's historical statehood, even if what it became was illegitimate. Finally, he changed the names of streets, places, and institutions to eradicate reminders of Tito and communism and to rehabilitate some of the émigrés' heroes, despite their association with the NDH.

Tuðman's claim that the Serbs exaggerated the scale of the Second World War genocide was forcefully put in the most controversial of all his writings, a book entitled Historical Wastelands, which was revised and reprinted in 1997 as Horrors of War. His main contention in this work was that the historical record of Croatia's role in the Second World War 'has been repeatedly and intentionally altered for political purposes' ${ }^{31}$ He argued that while the Belgrade government insisted that the Ustaša killed nearly 2 million Serbs, the official figures indicated that the real number of people killed within the territory of the NDH was around $60,000 .{ }^{32}$ While admitting that even the reduced number constituted an appalling crime, he argued that the figures were manipulated to legitimise the suppression of Croatian national consciousness after the Second World War. This was typified by the trial of Stepinac, the deposing of Andrija Hebrang (leader of the Croatian Partisans), the 'Croatian Spring' in 1971 and the imprisonment of Tuðman himself..$^{33}$ Tuðman also attacked attempts to imply the historical guilt of the Croatian people for the genocide. After pointing to several works that suggested that the Croatian nation had an inherent tendency towards genocide if left unattended, Tuðman went on to show that prominent Croatian nationalists such as Starčević and Radić proposed anti-fascist programmes and the extent to which Croats themselves participated in the antifascist struggle. ${ }^{34}$

Though a much maligned work, it is important to point out that Horrors of War did make some important contributions to the Croatian historical record. It is true that Jews were no better off in Nedićs Serbia than they were in Pavelićs Croatia during the Second World War. It is also true that the number of people killed at the Jasenovac camp was massively inflated and this inflated figure was used to suppress expressions of Croatian national identity. Furthermore, Tuðman's estimates of the total number of people exterminated by the Ustaša in death camps and massacres is closer to the figure given by most independent historians than the numbers emanating from Belgrade, but still missed the mark by around $100,000 .{ }^{35}$ However, it is a worrying piece of work because of its alleged anti-Semitic tone and because Tuðman appeared to be more concerned with the anti-Croatian plot that he was attempting to uncover than he was with Ustaša crimes.

Horrors of War fulfilled two purposes for Tuðman's broader mission. First, it purported to unite all Croats as the victims of a Serbian conspiracy to discredit the Croatian nation. Second, perhaps most worryingly and contentiously, it argued that the fascist NDH was a legitimate expression of Croatian 
statehood. In 1991 Tuðman argued that, '[b]ased on the historical tradition of Croatian statehood, the Independent State of Croatia [NDH] was established during World War II'. ${ }^{36}$ Even the post-independence constitution identified the $\mathrm{NDH}$ as one of the manifestations of Croatia's historic statehood in its preamble. It insisted that the NDH was responsible for 'laying the foundations of state sovereignty'.

Finally, the integration of the émigrés into Croatian society demanded that they be made to feel at home. One of the most distasteful ways that Tuðman proposed to do this was by deciding that the remains of Croats killed in the Bleiburg massacre of 1945 (which included perpetrators of the Ustaša terror) should be buried at Jasenovac alongside the remains of their victims in a memorial to all Croats killed in war. ${ }^{37}$ Not surprisingly, these plans caused uproar in Croatia and the government also came under immense international pressure, particularly from the USA. The crisis was resolved when Tuðman 'discovered' that among the bones already at Jasenovac were some returned from Bleiburg after the war, so no bodies needed to be exhumed and moved. ${ }^{38}$

The émigrés were made to feel welcome in their homeland by the changing of street names. A Zagreb street called 'December Victims Street' in commemoration of sixteen Croatian intellectuals hanged by the NDH in December 1943 was renamed 'St Peter's Street'. ${ }^{39}$ Mile Budak, the Ustaša Vice-President, had the former Duro Salaj Street named after him (Salaj had been a prominent antifascist fighter in the Second World War). ${ }^{40}$ The 'Victims of Fascism Square' in the centre of Zagreb became the 'Square of Croatian Heroes', and across Croatia thousands of streets, buildings and squares that were formerly named after anti-fascist fighters were renamed after Croatian 'heroes', many of whom had participated in the $\mathrm{NDH}$ abomination. ${ }^{41}$ After receiving protests about the removal of the names of famous anti-fascists from street names, Defence Minister Gojko Šušak retorted that there was no anti-fascism in Croatia because during the NDH period there was no fascist party. ${ }^{42}$

The rehabilitation of the émigrés and NDH was the most controversial aspect of the 'Franjoist' project. Rather than emphasising the anti-fascist elements of Croatian national identity, personified by his own past, Tuðman chose to attempt to unify the Croatian nation by emphasising its anti-communism at the expense of accommodating those most ardent of anti-communists, the fascists. This accommodation provoked many commentators to question Tuðman's political integrity.

Three additional Franjoist themes informed some of the government's key policies and shaped its conception of national identity. Each depended on a particular understanding of Croatian national identity and drew upon a particular interpretation of the historical statehood narrative. These were the focus on the primacy of Croatian sovereignty and independence, an exclusivist approach to citizenship, and the promotion of conservative clericalism.

Protecting the sovereignty and independence of Croatia was the one issue that united the disparate strands of the HDZ. This unity was only preserved 
through a contradictory discourse of sovereignty that described it, on different occasions, as either the sovereignty of the Croatian territory or the sovereignty of an ethnically defined Croatian nation. ${ }^{43}$ According to Tuðman, without the HDZ the dream of an independent and sovereign Croatia could not have been realised..$^{44}$ It is not clear, however, whether that independent and democratic Croatia was constituted by its Yugoslav boundaries or whether Croatia extended to all those places where Croats lived. In a message to Croatia's Serbs delivered on the eve of Operation Oluja in 1995, ${ }^{45}$ Tuðman seemed to suggest that he equated Croatian sovereignty with the territory of the Republic of Croatia. $\mathrm{He}$ noted that 'all the attempts of the Croatian state and the international community to peacefully restore Croatia's sovereignty over parts of Croatian territories alienated by the rebellion have been rejected' and thereby equated the limits of Croatian sovereignty with what was accepted by international society ${ }^{46}$ Similarly, after signing the Dayton Agreement, Tuðman announced that the 'great and holy aim' of the Croatian people was the attainment of 'total sovereignty over its entire, internationally recognised territory'. ${ }^{47}$

The President was occasionally less reticent about the limits of sovereignty, according it to the Croatian nation rather than the territorial boundaries of the state and focusing particularly on the Croats in western Hercegovina. Tuðman's stance on the Bosnian question caused Croatia to be frequently rebuked by international society. Tuðman was clumsy at best in his dealings with the Bosnian question. In an infamous meeting with Milošević in 1991, he raised the possibility of dividing Bosnia and Hercegovina between Serbia and Croatia. What Tuðman overlooked was the fact that Milošević himself had never publicly mentioned the possibility of partitioning Bosnia and Hercegovina. ${ }^{48}$ In 1995, Tuðman astonished the British politician Paddy Ashdown when he drew a map on a napkin showing a Bosnia and Hercegovina that had been partitioned between Croatia and Serbia. ${ }^{49}$

There were two main reasons for Tuðman's ambiguous stance towards Bosnia and Hercegovina. First, the so-called Hercegovinian lobby provided the President with valuable economic and political support and in return secured several top positions within the HDZ government, forcing Tuðman to take an active interest in Hercegovinian affairs. ${ }^{50}$ Second, Tuðman believed that he was president of all Croats, so he felt obliged to shepherd the strategic interests of his extended flock across the border. His historical research told him that 'Croatia and Bosnia constitute a geographical and political unity, and have always formed a joint state in history', ${ }^{51}$ though he was never clear on exactly when Croatia and Bosnia and Hercegovina shared the same state. The President also appreciated the nationalist activism of the Hercegovinian Croats, whose zeal for fulfilling his national dream was not shared by many Croats in Croatia particularly the Istrians and citizens of Zagreb, as we will see in the following chapters. During a visit to Mostar, the principal city in Western Hercegovina, Tuðman told his audience that 'you Hercegovinians are the ideal to all others in Croatia in many aspects'. ${ }^{52}$ In calling the Hercegovinians 'ideal Croats', Tuðman 
was crediting their political judgement. Allowed to vote in the Croatian elections, the approximately 365,000 Croats of Bosnia and Hercegovina voted consistently in favour of the HDZ. ${ }^{53}$ However, this position towards the Hercegovinian Croats formed only half of the paradox of HDZ's position on Croatian sovereignty. Therefore, the government fell short of openly and consistently advocating the secession of Hercegovina, attempted (unconvincingly) to distance itself from the Croat-Muslim war of 1993, and after 1995 supported crossborder ties with the Bosnian government in Sarajevo.

The HDZ's interpretation of the historical statehood narrative and its understanding of Croatian national identity also prompted it to adopt a particular position on the citizenship question. Although the constitution defined the state in national terms, this was not done at the expense of the rights of people of other nationalities residing in Croatia. Article 1 of the constitution proclaimed that 'in the Republic of Croatia power derives from the people as a community of free and equal citizens'. This community, we were told, consisted not only of Croats but also of 'Serbs, Muslims, Slovenes, Czechs, Slovaks, Italians, Hungarians, Jews and others' ${ }^{54}$ Clearly, such a formulation did not fit with the HDZ's belief that the Croatian state was intimately linked to the Croatian nation and the HDZ itself as the party of all Croats, but was necessary to persuade other states that Croatia was prepared to fulfil its international human rights obligations. The government therefore passed a citizenship law which, according to one observer, 'allow[ed] selective application of the right to citizenship based on whether the applicant is of Croatian or Serb nationality' in contravention of the constitution. ${ }^{55}$ The UN's special rapporteur, Elisabeth Rehn, noted that Article 8 of the Law on Citizenship demanded proof of continuous residence in Croatia of at least five years and 'proficiency in the Croatian and Latin script'. ${ }^{56}$ Rehn found evidence that this was being used to deny citizenship to Serbs and Muslims, many of whom had been long-time residents in Croatia. ${ }^{57}$ Additionally, Article 26 of the law allowed the Ministry of Interior to employ broad discretion in denying an application for citizenship on the grounds of the 'interests of the state' ${ }^{58}$ Similarly, the Croatian Helsinki Human Rights Watch group showed that the law stipulated that people not born in Croatia, nor of Croatian parentage, should be denied citizenship. ${ }^{59}$ The Helsinki group argued that this provision did not take into account the fact that Croatia was formerly part of Yugoslavia. People who had lived and worked in Croatia for the best part of their adult lives were therefore denied citizenship and thus employment and property ownership rights. ${ }^{60}$ While not denying the constitutional rights of Serbs to be citizens of the Croatian state, the law did represent an attempt to define the Croatian state as a manifestation of Croatian national identity. This position reflected a particular understanding of the historical statehood narrative which viewed statehood as a political manifestation of an ethnic Croatian community rather than viewing the nation as one constituted by the state and thus defined as simply consisting of those people who inhabited the territory of the medieval kingdom. 
The HDZ's interpretation of the historical statehood thesis was also evident in its overt clericalism. While Orthodoxy shaped the Serb national consciousness, Catholicism did not play a significant role in the historic statehood thesis. ${ }^{61}$ Indeed, national heroes, such as Jelačić, Archbishop Strossmayer and Stjepan Radić, either vehemently opposed clericalism (Radić), promoted ecumenicalism (Strossmayer) or emphasised the political rather than religious and ethnic nature of the nation (Jelačić). Tuðman, however, propagated clericalism and promoted the Catholic Church as the moral conscience of his Croatian nation in order to differentiate Croats from the Serbs, Bosnian Muslims and Yugoslavists, and hence provide a foundation for a unified Croatia. He began by rehabilitating Archbishop Alojzije Stepinac from the ostracism of communist historiography. Tuðman argued that Stepinac had been the shepherd of the Croatian flock during the troubled years of the Second World War and had helped many Serbs, Jews and Croatian opponents of the regime to escape the fascists. Stepinac's status as a martyr to the Croatian cause was exemplified by his trial and imprisonment and by his ceaseless attempts to protect the clergy from communist purges. ${ }^{62}$ In his 1996 State of the Nation address, Tuðman identified the establishment of good relations with the Vatican as a cornerstone of his foreign policy. ${ }^{63}$

The HDZ's clericalism did not bring the nation together, however. Polls conducted before 1991 showed that Croatia had the lowest proportion of religious believers of all the Yugoslav republics. ${ }^{64}$ Furthermore, policies that were inspired by the HDZ's clericalism, such as strict abortion laws, met with considerable opposition and resentment, especially among the urban young in Zagreb, Rijeka, Split, Osijek and Dubrovnik. The slogan, 'Even a Foetus is a Little Croat', designed to expose the connection between rigid Catholicism and 'good' Croatianism, did little to further the cause of Franjoism among liberal Croats. ${ }^{65}$ Furthermore, the Church-HDZ union produced many instances of religious intolerance and the presence of priests among the HDZ's representatives did much to discredit Catholicism. ${ }^{66}$

The HDZ, a broad coalition of nationalists with Tuðman as the linchpin, therefore attempted to transplant its own unity of thought on the subject of the Croatian nation on to the nation itself. Observers pointed out that Tuðman was perpetually struggling to restrain the more extreme elements of his party who wished to extend Croatia into Hercegovina and create an ethnically pure and Catholic state. ${ }^{67}$ According to his political opponents, in attempting to bridge the differences between Croats and create the myth of a common yearning for statehood, Tuðman made too many concessions to extremists and expatriates. This left him hamstrung on a number of issues. Tuðman, the anti-fascist, never publicly distanced himself from the NDH. Widely credited with going to great lengths to avoid the 1991 war with the JNA, ${ }^{68}$ he was seen to vacillate over the Croat-Muslim war in 1993. The HDZ failed to transform the abstract historical narrative of the 'centuries-old dream' into a less abstract and materially resonant narrative of contemporary Croatian national identity with which different Croats could associate. ${ }^{69}$ 
The so-called 'Zagreb crisis' shows that the HDZ thought that there were times when the cause of national unity demanded that democracy be subverted to prevent its (and thus Croatia's) enemies coming to power. In the 1995 local assembly elections, the opposition secured thirty-one of the fifty seats in the Zagreb municipal council. Tuðman was faced with the possibility of an opposition mayor in the economically vital capital city and feared that an opposition council would take too much of an interest in the HDZ's financial affairs. ${ }^{70}$ At the very least, property and institutional services previously at the disposal of the HDZ would become tools for the opposition. Tuðman invoked a national security clause in the constitution that allowed him to veto the appointment of top officials. He rejected four opposition choices for mayor of Zagreb and named his own commissioner to run the capital's affairs. ${ }^{71}$ This was justified by two typically Franjoist arguments. First, Milan Ivkosić, writing in the governmentfriendly newspaper Hrvatski Obzor, ${ }^{72}$ argued that the immature opposition parties were acting undemocratically because the HDZ was the single largest party in Zagreb and should therefore have the right to select the mayor. ${ }^{73}$ Second, Tuðman explained that his actions represented those of a caring father forced to do unpleasant things to protect an errant child from itself:

It is important that our public understands that the situation in which Croatia finds itself regarding the problems of the liberation of the remaining occupied territories and the crisis in Bosnia-Hercegovina is such that we cannot allow that sort of opposition which would rock Croatia's stability to take root in the city of Zagreb, capital of Croatia where a quarter of the Croatian population live. ${ }^{74}$

A political threat to the HDZ was thus reconstituted as a threat to the stability of Croatia itself.

Much of the HDZ's rhetoric was imbued with the language of war, threat and instability. Throughout the 1990s, illiberal measures were justified by the necessities of war. The war ended in 1995 and the last piece of territory administered by the UN (UNTAES) was returned to Croatian administration in January 1997. However, the HDZ failed to reinvent itself. Instead, Tuðman embarked on a search for new enemies for the (right-minded) Croatian people to unite against. This constant threat required the unity and vigilance of the Croatian people mobilised through the HDZ.

The Franjoist project of national integration continued after the war through the construction of new threats for the nation to unite against. On one level, Franjoist rhetoric could be construed as being little other than the employment of rhetoric to accommodate disparate groups in a nationalist movement. Each of the pillars of Franjoism can be seen as appealing to different sections of the HDZ and its policies were designed to reinforce the ruling party's power. Certainly, this instrumental account can explain why Tuðman, the former Partisan, included the rehabilitation of fascists within his political discourse. It also explains his paradoxical views on Hercegovina and the dualism deployed in his discourse on sovereignty. However, many observers described 
Tuðman as a 'true believer' of nationalist rhetoric. He was both its founder through his historical writings and its guardian against anti-Croatian tendencies. He did not, however, persuade all other Croats that the Franjoist account of their national identity was the real manifestation of their centuries of shared statehood. Despite claiming to bridge the cleavages within Croatian society, he defined those cleavages narrowly, as being only those between fascism and communism. He was vehemently opposed to internal regionalism for instance, because this posed a challenge to his carefully constructed unity. He also used all the bureaucratic power of the state to silence those who claimed that he was not a good shepherd of the Croatian flock and was not even a particularly important character in the play of Croatian history. One of the reasons why Tuðman's Franjoist account of national identity remained dominant throughout the 1990s was precisely that there were so many alternative accounts. There was no single alternative that stood in opposition to Franjoism. The rest of this chapter will consider these other accounts showing how they made different use of the frames provided by the historical statehood thesis.

\section{Opposition voices: political parties}

In contrast to the ideas of national unity articulated by Franjoists, opposition politics was highly fragmented in the 1990s and failed to offer a cohesive counter-narrative. One of the central points of dispute among opposition parties was the question of how they should relate to Tuðman's HDZ. On the one hand, the eventual partners in the winning coalition of the 2000 parliamentary elections, Ivica Račan of the Social Democratic Party (SDP) and Dražen Budiša of the Croatian Social Liberal Party (Hrvatska Socijalno Liberalna Stranka HSLS) advocated a co-operative approach to the HDZ to ensure a peaceful transition from HDZ governance. Others, such as Vlado Gotovac of the Liberal Party (Liberalna Stranka - LS), and the leaderships of the Istrian Democratic Assembly (Istarska Demokratska Sabor - IDS), Croatian Peasants' Party (HSS) and Croatian People's Party (Hrvatska Narodna Stranka-HNS), suspected that any dialogue with Tuðman would be unproductive and would only reinforce the President's claim to democratic credentials. ${ }^{75}$

Opposition politics had two important features in the 1990s. First, opposition politics operated in a hostile environment. The HDZ was better funded, controlled the media and manipulated the electoral system to its own advantage. The second characteristic was fragmentation. Opposition parties organised themselves into coalitions that tended to change from election to election. In the 1991 elections the Croatian Peoples Party headed by the leaders of the 1971 'Croatian Spring', Savka Dabčević-Kučar and Mika Tripalo, joined with the HSLS to form the Coalition for National Accord. The socialists formed a second coalition, and the nationalist Party of Rights (HSP) joined with the HDZ to form a third coalition. ${ }^{76}$ In 1997 the HSLS was joined by the more conservative- 
minded Croatian Peasants' Party (HSS), while the HNS joined with the SDP, as did the newly formed Croatian Independent Democrats (HND), which was established by HDZ defectors Stipe Mesić and Josip Manolić. More often than not, it was clashes of personality rather than policy differences that caused the coalitions to change, though the overriding factors were the questions of relations with the HDZ and the electoral success or failure of each coalition. Within this context of shifting alliances there were broadly four groups of parties. These were: extreme nationalists, socialists, liberals, and regional and centrist parties.

The HSP, founded by the extreme nationalist, Dobroslav Paraga, claimed to be the direct descendent of the nineteenth-century party with the same name, which had been established by Starčević and Kvaternik. ${ }^{77}$ It insisted that the Croatian people had an inalienable right to their own state, a right that drew directly from the historical statehood narrative. It was even more radical than the HDZ in calling for Croatian independence, a unitary national state and the revision of the republic's borders. Paraga was himself jailed in 1980 for collecting signatures demanding the release of political prisoners. In the eleven years following this he came to embrace many of the ideas and organisational facets of the pre-war Ustaša movement, even becoming a self-proclaimed fascist. ${ }^{78}$ Paraga demanded 'Hrvatska do Drine' (Croatia to the Drina), which meant that the HSP advocated the revision of borders so that Bosnia and Hercegovina, up to its River Drina border with Serbia, could be incorporated into Croatia - something that not even the fascist Ustaša state had achieved. This policy drew directly on Starčević's observation that the Bosnian Muslims were simply Muslim Croats, and that the Bosnian (and Croatian) Serbs were merely Orthodox Croats. Interestingly, the far-right HSP concentrated on matters of religion and ethnicity much less than the HDZ did. For Paraga, the Croats were an explicitly political nation, incorporating all the peoples and territories of the farthest reaches of the medieval kingdom, regardless of their religion or ethnicity.

The HSP was a vociferous opponent of the proposed partition of Bosnia and Hercegovina, arguing that Croatia should enter into an immediate confederation with Bosnia and Hercegovina with a view to eventual union should the people of Bosnia and Hercegovina assent to it. This was another of Starčević's legacies. As Starčević had done, the modern HSP argued that the 'Serbs' and 'Muslims' of Bosnia and Hercegovina would naturally come to recognise their Croatianness over time. Therefore (while using Ustaša symbols and venerating Pavelić) it insisted that the ethnic cleansing and genocide attempted by the Ustaša was a crime against an ostensibly Croatian people. The HSP repudiated attempts to carve out an ethnically 'pure' state of Herceg-Bosna in Western Hercegovina. This led to a major division within the extreme right wing and the creation of another Party of Rights, HSP - 1861, which aligned itself more closely with the Frankist and Ustaša traditions of violent pursuit of ethnic purity. ${ }^{79}$

Paraga's party imitated the paramilitary structures of the Ustaša. The HSP attracted the same sort of disaffected youths that had joined Pavelićs movement 
and organised them into the Hrvatske Obrambene Snage (Croat Defence Forces - HOS), an armed paramilitary group. Paraga's men helped in the defence of Vukovar, which brought him into conflict with Tuðman. Because he insisted that every centimetre of Croatian land should be defended to the last man, Paraga believed that the government's failure to organise the relief of Vukovar was tantamount to treason. Clearly, there could have been nothing more dangerous to Tuðman's nationalist credentials than to be accused of being unpatriotic. ${ }^{80}$ A year later, Paraga dispatched his HOS forces to Bosnia and Hercegovina to defend the Croatian people and work with the Bosnian government forces fighting the Serbs. He believed that it was incongruous for the Bosnian Croats to fight the Bosnian Muslims because that meant allying with the real enemy, the Serbs. When fighting broke out between Croats and Muslims, he ordered his forces not to co-operate with the official HVO forces and was subsequently arrested on terrorist charges. Tuðman denounced him as an Ustaša fascist and forcibly integrated the HOS into the HVO (the Croatian Defence Committee the 'offical' Bosnian Croat army). ${ }^{81}$

According to HSP spokesman, Vlado Jukić, the fundamental problem that confronted Croatian politics in the 1990s was not that Tuðman was too strong (on occasions, as in Vukovar and Bosnia and Hercegovina, he was not strong enough), but rather that the opposition was too weak. ${ }^{82}$ Jukić considered Tuðman's national narrative to be too broadly defined and argued that it should have focused solely on the right of Croatian statehood. According to Jukić, the other opposition parties were 'pseudo-liberals and former communists' who were more interested in criticising the HDZ than in securing the Croatian state. ${ }^{83}$ The HSP's veneration of the Ustaša allowed Tuðman to harass and impede it in ways that he could not do with the other parties. The reason for this over-zealous response to what was an electorally small party was that the HSP criticised Tuðman on his own Franjoist terms. According to the HSP, Tuðman was neither an ultimate patriot, strong leader, nor trustworthy historian. None of the other opposition parties attempted to offer an alternative account based upon Franjoism. Instead they argued that Franjoism itself constituted a distortion of the historic statehood narrative.

The Social Democrats (SDP) distanced themselves from their communist past by tracing their roots to the tiny Social Democratic Party of Croatia and Slavonia, formed in 1894 . This party was marginalised by the communists and then abolished in $1941 .^{84}$ The modern SDP had its antecedents in two movements. The first was the liberal reformist movement within the Croatian League of Communists. At the League's congress in January 1990 the reformists won a majority and called for immediate democratic elections in Croatia. The second developed outside the League of Communists in the guise of the Social Democratic Party of Croatia (SDH), under the leadership of Antun Vujić. Initially, the SDH opposed the SDP, viewing it as the perpetrator of a one-party state, but in 1993 both parties came together within the SDP under the leadership of Ivica Račan. ${ }^{85}$ The SDP had to conduct a difficult balancing act, distancing itself from 
the former communist regime while maintaining the good will of its traditional supporters, many of whom accepted political pluralism only grudgingly. ${ }^{86}$ Furthermore, the SDP was the only Croatian majority party that contained a large number of Serbs. This cleavage was made more troublesome by the fact that most Serb members of the SDP opposed pluralism while most Croats advocated it. ${ }^{87}$ These cleavages were at the very heart of the social democratic movement and almost resulted in the stillbirth of Croatian democratisation in 1990 when there was an attempt to bring down the liberal wing of the party and impose a purge of the kind witnessed in the 'Croatian Spring' of 1971.8

These problems were resolved when most Serbs left the party to join the separatist Serb nationalist parties, allowing the SDP to become more overtly Croatian-centric and politically pluralist. At its inception, the SDP-SDH's views on national identity were full of ambiguity and contradiction. Initially, it sought to emphasise the positive role it played as the former ruling party in carrying out the peaceful reform of the communist system and allowing free elections. It also stressed its independence from the other Yugoslav communists and especially from Milošević. In the first election, the SDP-SDH advocated the maintenance of the Yugoslav federation, although it was alone among the Croatian parties in doing so. As more Serbs joined the Serbian nationalist parties, the SDP-SDH revised its position and advocated the confederal ideas espoused by other parties. It is interesting to note that the official literature produced by the SDP in the run-up to the 2000 elections, in which it became Croatia's largest party, insisted that the party had always advocated confederalism. ${ }^{89}$

The leader of the SDP, Ivica Račan, has a reputation as a liberal-minded social democrat. ${ }^{90}$ According to Račan, the state has a responsibility to look after the social welfare of the people who helped and suffered in the fight to establish an independent state. ${ }^{91}$ Račan focused on the social and economic emancipation of the peoples in the Croatian state. For him, the central political goals were 'enhanced economic growth and a greater degree of social security'. ${ }^{92}$ Agreeing with the liberals and the regional parties, the SDP argued that Croatia should integrate into the European Union (EU) as soon as possible. ${ }^{93}$

The cleavages within the SDP were most obviously exposed by the national question. Račan was adamant in his support for the independence and territorial integrity of Croatia and Bosnia and Hercegovina. He was also keen to reiterate the SDP's multinational traditions, insisting that the 'SDP has always been a multiethnic party which is sensitive to the issues surrounding the protection and integration of ethnic minority communities in Croatia' ${ }^{94}$ However, he has been criticised for not being critical enough of Croatian nationalism. Noting that it had supported Operation Oluja, Bogdan Denitch criticises the party not only for not challenging nationalism but also for exhibiting nationalist tendencies itself..$^{95}$ Furthermore, Denitch notes that by displaying implicit nationalist tendencies, the SDP had betrayed its core interest in the social welfare of the Croatian people since, he claims, the Croats lost the most through the demise of Yugoslavia. ${ }^{96}$ 
Because the SDP remained uneasy about its own communist history it was unable to constitute itself as a patriotic party on its own terms, as the liberal and centrist parties did. In order to portray itself as patriotic it desisted from criticising Tuðman and actively supported the government abroad. On one occasion a delegation from the SDP attempted to persuade the European Parliament not to pass a resolution that condemned the Croatian government for its human rights record. ${ }^{97}$

By the time of the parliamentary election in January 2000, however, the SDP had almost completely reconstituted itself. Because the key issues at this election were more closely akin to the 'normal' issues of European democratic politics - the economy, welfare and so on - the SDP was able to present itself as the most patriotic party. While the return of Serbian refugees to Croatia, and co-operation with the International Criminal Tribunal (ICTY) remained vexed questions, they were no longer as significant as the questions of unemployment and the standard of living - questions on which only the SDP had a long track record of activism. Thus, in the 2000 elections the SDP became the single largest party and its leader, Ivica Račan, was appointed Prime Minister.

Of all the opposition parties, the SDP was least certain in articulating a Croatian national narrative. This was because historically the SDP had a large number of Serbs within its leadership. However, since most of the Serbs left the party and because the SDP needed to attract Croatian voters, it had to appear patriotic. It did this by defending what it believed were Croatia's interests even at the expense of defending the HDZ and de-emphasising some of the other central tenets of its political programme such as multinationalism. This approach saw it climb from virtual extinction in the middle of the 1990s to being the largest party in Croatia in the first post-Tuðman elections.

The liberal parties were undoubtedly the parties of the Croatian intelligentsia. The three most prominent members of the liberal movement, Dražen Budiša, Vlado Gotovac and Ivo Banac, were all well-known academics, and were all considered to be dissidents during the communist era. With the arrival of democracy, 'the Liberals were then the showcase of Croatia - all the bearded intelligentsia, all the liberal professors of sociology, artists, feminists, even anarchists'. ${ }^{98}$ In other words, the liberals were the 'chattering classes' of Croatian urban society, 'interested in Croatia as a modern, yet decidedly Mitteleuropean country'. ${ }^{99}$ For the liberals (as for Tuðman), Croatia was meant to be everything that Yugoslavia was not. It would be a modern, free and democratic state based on romantic visions of what it was to be Western European. ${ }^{100}$ However, despite having the same rhetorical orientation as the HDZ, the liberals looked upon Tuðman's party with disdain, seeing it as little other than a populist manifestation.

Founded in 1989, the Croatian Social Liberal Party (HSLS) was the first non-communist political party to be established in Croatia after the Second World War. It contained two distinct wings from the outset: the singularly liberal and nationalist-populist. As with the HDZ, the different wings of the 
party were reconciled by their president, Dražen Budiša. ${ }^{101}$ The first HSLS programmes focused on the economy, privatisation and wealth creation. ${ }^{102}$ Its core principles were those of classical liberalism. The HSLS argued that, 'free is the community in which every individual is free and socially secure' ${ }^{103}$ Its vision for Croatia was one of liberal democracy, social cohesion, the inalienable rights of the individual, the limitation of government, the principle of demilitarisation, and the need for open and tolerant dialogue between different interest groups. ${ }^{104}$ On the national question, the HSLS advocated respect for the human and civil rights of the Serb minority, although it did not emphasise this as much as the SDP. Being an explicitly Croatian party, the HSLS described the areas of Croatia held by the Serbs as occupied territories and after Operation Oluja sent Tuðman a note of congratulation. ${ }^{105}$ As with the other opposition parties, the HSLS saw the Croatian polity as extending only to the republic's border and not to all Croats wherever they lived. It viewed the nation in liberal terms as a diverse group of individuals. The HSLS advocated the decentralisation of power and the promoted regionalism as a way of combating the national homogenisation pursued by the HDZ. ${ }^{106}$

Dražen Budiša had good nationalist credentials. He was the leader of the Croatian League of Students during the 'Croatian Spring' and was sentenced to three years in jail for his anti-regime activities. ${ }^{107}$ According to Budiša, the HSLS was the 'party of the third direction', which charted a path between socialism and conservatism. ${ }^{108}$ This 'third way' drew upon Radić's legacy and a tradition of Croatian middle-class thinking that was developing at the turn of the twentieth century. Budiša gave the HSLS a confident national outlook, arguing that the liberals played a vital role in securing independence for Croatia and that they most accurately reflected the aspirations and history of the Croatian people. ${ }^{109}$ Budiša argued that the rule of law should provide equality of opportunity and that the core principle of governance should be subsidiarity, allowing individuals to shape the national destiny rather than the other way around.

The party split following disastrous election results in 1997, in which the HSLS secured only one seat in the Sabor. Many of the leading members followed Vlado Gotovac into the new Liberal Party (LS). One of the defectors, Ivo Banac, accused Budiša of legitimising Tuðman's rule by forming what he described as a 'normal opposition' that treated the HDZ as a 'normal' democratic government by co-operating with it. ${ }^{110}$ The split in the HSLS, while ostensibly about the level of co-operation with the HDZ, was more fundamentally concerned with the place of the nation within liberal political programmes. For Budiša, the relationship between the nation and liberalism was mutually constitutive and the defence of liberalism demanded the defence of the nation. For the Gotovac faction, however, placing the national collective at the centre of the political programme implied a devaluation of the individual and thus a denigration of a view of the nation as a group of diverse individuals pursuing their interests. ${ }^{111}$

The President of the Liberal Party, Vlado Gotovac, was a poet, essayist, philosopher and journalist. He was jailed for four years for his part in the 
'Croatian Spring', and was given a further two years in jail for giving an interview on Croatia to a Swedish television network. During this period, Gotovac published work with Franjo Tuðman. ${ }^{112}$ Gotovac defended the importance of the nation, because - contra Tuðman - the existence of nations implied difference and 'diversity makes the world more interesting. ${ }^{113}$

The core principles of the LS were almost identical to those of the HSLS, though with a more pronounced emphasis on the individual. According to a declaration adopted at the end of the party's founding congress, individual freedom meant 'freedom from compulsion' and the interference of state authorities. ${ }^{114}$ Stronger emphasis was put on limiting state power, individual equality before the law, and the proper functioning of a liberal economy. ${ }^{115}$ These principles, it claimed, drew from a Central European tradition within Croatian political thought that had not previously been articulated in Croatia, because it was subject to alien and illiberal rule. Much of its programme was concerned with ensuring individual rights and criticising the government's record. It argued that 'Croatia is today centralised, bureaucratic and metropolised', there was 'no public opinion', and what public opinion there was 'cannot have influence on either resignation of any minister or any serious consequence or social treatment'. ${ }^{116}$

The tension between political programme and national narrative, which caused the ambiguity within the SDP programme, also caused the fragmentation of the liberals into two parties. The HSLS tended to locate liberalism within a prior narrative of the Croatian nation and was therefore mute on the question of what the idea of a liberal Croatian nation meant in relation to Franjoism. This was because the HSLS chose not to challenge the HDZ's national narrative, only the government's specific practices. In contrast, the radical liberals who joined the LS refuted Franjoism's national ideology, contested its ownership of the Croatian political tradition, and rejected the legitimacy of HDZ rule. The LS could claim to be as 'Croatian' as the HDZ in a way that the SDP could not and the HSLS chose not to because of its adherence to the Franjoist national narrative. The leaders of the LS had as good a record of Yugoslav dissidence as Tuðman. They argued that the legacy of Croatian political thought was liberal and Central European and should have produced a political vision of national identity rather than one based on ethnicity, religion and language.

Along with the Party of Rights (HSP), the other party that could claim a direct antecedent in pre-communist Croatia was the Croatian Peasants' Party (HSS). The HSS resumed its activities in 1992. It was the leading party in the socalled 'group of four' (a coalition with HNS, LS and IDS) coalition that came third in the 2000 parliamentary elections. Like the HSP, the Peasants' Party attempted to emulate is predecessor both organisationally and ideationally. According to Vladko Maček, one of the strongest elements of the party's prewar organisation had been its activity at the grassroots level. ${ }^{117}$ Accordingly, the contemporary HSS put a great deal of effort into building a network of local organisations, which saw it increase in popularity from its first election where it won only 4 per cent of the vote. ${ }^{118}$ 
The HSS advocated decentralisation of the state and the democratisation of local government as ways of promoting participation in politics. It combined Radićs anti-clerical nationalism with a revised citizen-oriented republicanism that contested many of the conclusions reached by the Franjoists. ${ }^{119}$ Because of its conservative orientation, it concurred with the HDZ's handling of the war effort but disagreed with the idea of annexing parts of Bosnia and Hercegovina. The HSS believed that Tuðman hindered progress towards the democratic republic aspired to by Radić. This was clearly a major problem for Tuðman, who, like the liberals, had to make a leap of interpretation when claiming to represent the views of Radić, while the HSS did not have to make such a leap. To have the HSS identify Tuðman (rather than Serbs) as the major obstacle to fulfilling Radić's dream was understandably damaging to the Franjoist project. ${ }^{120}$

The Croatian Independent Democrats (HND) were produced by defections from the HDZ engineered by two leading members, Josip Manolić - former President of the House of Counties - and Stipe Mesić, the last President of the SFRY (Socialist Federative Republic of Yugoslavia) and former President of the Croatian House of Representatives, the central legislative branch of the Sabor. They argued that Gojko Šušak and Franjo Tuðman had taken the HDZ away from its core principles of freedom and democracy towards authoritarianism. Manolić and Mesić claimed to offer solutions to the Serbian and Bosnian problems that were more prudent than the policies espoused by the right wing of the HDZ. According to Mesić, Tuðman was seduced by the powerful right wing of the party, which tended towards 'Bolshevik' practices. The ruling party, he claimed, had closed Croatia in behind a 'Balkan wall' of totalitarianism that prevented its progress into Europe. ${ }^{121}$ In response, Tuðman argued that it was inevitable that there would be 'turncoats', because the HDZ was a movement encompassing every strand of Croatian opinion. ${ }^{122}$ The HND countered by insisting that by 1993 Franjoism had begun to destroy its own principles. Most importantly, the very things it fought for in Croatia it was denying to Bosnia and Hercegovina, and the very things it opposed during communism, such as restrictions on the media and freedom of speech, had become characteristic features of the new regime.

The most radical rearticulation of Croatian national identity by an opposition party was produced by the Istrian Democratic Assembly (IDS). The IDS was originally formed to protect the interests of the Istrian region against what it saw as homogenising Croatianism emanating from Zagreb. It was ideologically oriented towards the liberals and participated in coalitions with the HSLS. It was distinct inasmuch as it demanded the federalisation of Croatia. National identity in Istria is mixed between Croats, Slovenes and Italians, but tends to be subsumed by regional identity. The 1991 Yugoslav census offered the population the opportunity to describe themselves as one of 25 nationalities, as 'Yugoslav' or 'regional'. In Istria, 'despite the Croatian government's efforts to infect Istria with its own virulent nationalism, the townspeople registered the highest number of "regionals" anywhere in the federation: 36 per cent'. ${ }^{123}$ The 
IDS became dominant on the peninsula, controlling all the local authorities and pressing its case for regional autonomy. ${ }^{124}$ The IDS programme constituted a major threat to Franjoism because it involved a large group of Croats denying the idea of national homogeneity and claiming a separate history for themselves and the right to determine their own destiny (see Chapter 6).

The government responded harshly to the IDS threat. On the one hand, it contained the IDS within Istria by denying it access to the national media. ${ }^{125} \mathrm{On}$ the other, it portrayed the Istrians as not being 'true Croats' and the IDS as being engaged in a programme of 'de-Croatisation' in Istria. In order to bolster its position, the government attempted to resettle Croatian immigrants from the USA, South America, Australia, Germany and Bosnia and Hercegovina, in Istria. Because the Croatian diaspora is generally thought to be radically nationalist, it was intended that its influx would diminish Istrian regionalism and 'Croatianise' the region. ${ }^{126}$ However, the scheme was less than popular among the diaspora and the number of people who 'returned' to Istria was relatively small.

The IDS was the only major opposition party in Croatia to fundamentally challenge the historical statehood narrative. The other parties made use of the frames provided by this narrative to challenge Tuðman's interpretation of it and the place that he awarded himself within it. For instance, the HSP drew directly from the teachings of Starčević and the writings of Ustaša ideologues such as Mile Budak. In doing so, it was able to argue that Tuðman was not the modern manifestation of Starčević because he was not radical enough in his defence of the Croatian state. Similarly, the HSS exposed how Franjoist rhetoric and practice deviated from the teachings of the Radić brothers by excluding citizens from decision-making processes, contemplating the partition of Bosnia and Hercegovina, adopting clericalist overtones and causing the impoverishment of the many for the enrichment of the few. The other main parties argued that far from Europeanising Croatia, Tuðman was responsible for its Balkanisation. While Tuðman claimed that Croatia belonged to the Central European political sphere, he acted like a Balkan despot. Hence, it was claimed, Franjoism had nothing to do with either the legacy of Croatian state-right or its political and social culture and was thus self-defeating in its attempt to distance Croatia from all things Yugoslav, as it was only through Franjoism that the two were related. The IDS, however, argued that the twin notions of state-right and a Croatian tradition of political thought were not applicable to Istria because the peninsula had a history and political culture that was distinct from that of Croatia proper.

Although opposition political parties provided the most significant organised opposition to Franjoism in the 1990s, they were not the only source of opposition. Another, more radical, source of opposition were dissident intellectuals. There were many such writers, including Roman Ratković, Boris Buden and Dubravka Ugrešić, but there is only space here to consider two as indicative of the types of challenges to dominant modes of thinking posed by dissident 
intellectuals. The first, Ivo Banac, radically re-evaluated political and historical narratives about Croatian national identity. The second, Slavenka Drakulić, completely rejected such narratives and the political claims they supported.

\section{Dissident voices: two intellectuals}

According to Katherine Verdery, intellectuals across Eastern Europe were prominent in articulating visions of national identity. ${ }^{127}$ In the nineteenth century, Croatian intellectuals contributed to the national movements by questioning the roots of people's origins and tracing their genealogies. ${ }^{128}$ Intellectuals questioned the languages people spoke, speculated about what languages they ought to speak and articulated the recent political past in such a way as to propose a way forward for the group.

Ivo Banac ${ }^{129}$ was a dissident during the communist era. His two most important works, The National Question in Yugoslavia and With Stalin Against Tito: Cominformist Splits in Yugoslav Communism, were heavily criticised by the communists. The former explored how the idea of Yugoslavia manifested in the pre-Second World War kingdom was contrary to the visions of both Croatian Illyrianists and exclusivists. This work was condemned by the communists for being nationalist and contrary to Yugoslav 'brotherhood and unity' because it suggested that the Yugoslavs had not solved the national question and highlighted tensions between the Croats and Serbs. The latter book was also criticised for focusing on splits within the Yugoslav League of Communists and suggesting that throughout the party's history there was a large group of Yugoslav communists who were overtly Stalinist. Unlike other dissidents, such as Marko Veselica, Petar Šegedin, Franjo Tuðman and Zlatko Tomičić, Ivo Banac was not integrated into the new mainstream Croatian nationalist discourse in the 1990s. The main reasons for this were his participation in the Croatian Helsinki Human Rights Committee, which produced several reports that were highly critical of the post-communist government, and his membership of the HSLS and subsequently the LS. ${ }^{130}$

Although highly critical of the Tuðman government, Banac remained judicious in his analysis. While aptly pointing out that 'Tuðman is decidedly not an Ustaša' he noted that 'unfortunately, the amateurishness of the new administrations, their preoccupation with symbols and trivial matters, as well as their populist politics, all notable especially in Croatia, have hampered a more determined transition to democracy'. ${ }^{131}$ Banac argued that Franjoism attempted to be all things to all Croats by purporting to be the manifestation of a centuries-long tradition of political thought. The bulk of Banac's work on national identity, however, pointed to the differences within this tradition and questioned whether any coherent themes arose from it. Banac's work insisted that the Franjoist ideology was a particular interpretation of this tradition, not evidence of its unification. 
Public responses to Banac's work were extremely critical. Zeljko Sabol wrote that it is Banac who despises the Croat people. This is the root of his patronising attitude. Otherwise he wouldn't have been so intolerant of "evil" HDZ members'. Commenting on an interview Banac conducted in Feral Tribune, Sabol proclaimed that, 'Banac's interview ... seems like an outburst of a man blinded by hate'. ${ }^{132}$ Elsewhere, Banac was accused of revising Croatian history and indulging in 'activities' of a sexual nature with 'Četnik' women. ${ }^{133}$ The main reason for the vehemence of these attacks was that Banac's work challenged the historiography of Franjoism and the HDZ's status within it.

It was Ivo Banac who first articulated the historicist nature of Croatian national identity. In tracing literary and historical works that addressed the Croatian national question, Banac showed that such works tended to make legal rather than linguistic or cultural arguments. ${ }^{134} \mathrm{He}$ accounted for this tendency by suggesting that the early intellectuals and nobles believed that the idea of historical statehood would carry more favour in the Habsburg and Magyar courts. ${ }^{135}$ This predilection meant that the primary vehicles for national integration were the office of the Ban and the continuing institution of the Sabor. However, Banac suggested that the diminishing jurisdiction of these two institutions in the nineteenth century weakened the Croatian national body and contributed to the diversity of national programmes that were disseminated on the eve of the First World War (see Chapter 3). ${ }^{136}$ Furthermore, he argued that because the nineteenth-century national imaginings were a direct response to aggressive Magyar nationalism, the basis of 'their national idea therefore could not be, strictly speaking, Croatian'. ${ }^{137}$ Such ethnic exclusivism 'could be misunderstood as an expression of narrow Croatian regionalism - of the Kajkavian dialect area around Zagreb, which was generally regarded as Croatia proper at the beginning of the Nineteenth Century'. ${ }^{138}$

Banac made several important points about the early articulation of the claim to historical statehood. The most prominent and oft cited of these conclusions was that the relationship between the Croatian nation and Catholicism was not as clear-cut as some made out. Unlike the Serbian Orthodox Church, the Catholic Church is an institution with a universalist yearning in that it hopes to make all people Catholic. It cannot therefore be a national institution because it does not promote national exclusivity. The borders of Catholicism and Croatianism are different. Thus, Banac argued, Catholicism could not play a significant role in either defining Croatian national identity or as a vehicle for its preservation. ${ }^{139}$ He continued, 'the ideologists of Croat nationhood, almost to the last practicing Catholics, resisted the equation of Catholicism and Croatdom'. ${ }^{140}$

Banac argued that the idea of the Croatian political nation led to considerable confusion. For example, in the previous chapter we noted that Ante Starčević argued that everybody who resided within the boundaries he drew for Croatia were Croats. Banac argues that this did not mean that Starčević denied the multinational character of the lands and espoused the kind of 'final solution' propagated by the Ustaša. Rather, 'his Croats were a historical - indeed moral - 
community, not a community of blood. The borders of Croatia were set by primary acquisition not by migrations of a linguistic community'. ${ }^{141} \mathrm{~A}$ Croat was neither somebody who was Catholic nor somebody who spoke a particular dialect. Instead, a Croat was simply anyone who lived on the territory of the Croatian state.

Croatian national ideologists opted for the historical statehood narrative rather than a religious or ethnic discourse because such narratives were used against Catholic Austrians, Venetians and Magyars and not against the Orthodox Serbs or Muslims. This led to a strong emphasis on reciprocity among Slavs, often at the expense of Croatian exclusivity. The parcelling out of Croatian lands among different empires also produced the various regional identities so loathed by Tuðman. ${ }^{142}$ One manifestation of this was the different sentiments displayed by nationalists towards Dubrovnik. Banac argued that during the early period of Croatian nationalism the veneration of the old republic of Dubrovnik and in particular the literary works of Ivan Gundulić provided one of the key focal points for the movement. ${ }^{143}$ Conversely, however, Dubrovnik became an irritation to some early nationalists precisely because of its separateness. Banac pointed out that Starčević was most perplexed as to why so many Croats venerated the idea of Dubrovnik, when its separateness cast doubt on the city-republic's relationship with the rest of Croatia. ${ }^{144}$

Banac did not try to uncover a unified historical narrative of Croatian statehood, like those articulated by Stephen Gazi, Stanko Guldescu and Franjo Tuðman. Instead, he chose to focus on particular writers who articulated visions of Croatia and attempted to situate them within the various traditions of Croatian national thinking. ${ }^{145}$ In one such work he concentrated upon the writings of Pavao Vitezović, author of the famous article Croatia Rediviva, the earliest work of the Illyrian tradition. Vitezović was the first writer of the postRoman era to envisage the idea of Illyria, a territory that for him spanned the entire Balkan peninsula except for southern Greece. ${ }^{146}$ According to Banac, during the period when Vitezović was writing (the seventeenth century), the words 'Croat' and 'Illyrian' were common synonyms ${ }^{147}$ It was through Vitezović that the idea of the reunification of the Croatian lands was first postulated. Through the separation of the terms 'Croat' and 'Illyrian' the groundwork was laid for the two key traditions in Croatian national thinking - the exclusivism of Starčević and Kvaternik, and the Illyrianism of Gaj and Strossmayer. ${ }^{148}$ If we see Vitezović as the earliest proponent of the Illyrian pan-Slavism that developed in the nineteenth century, Banac's study of Milan Šufflay represents an attempt to articulate the vision of a key member of the exclusivist tradition. Šufflay, who wrote most of his work during the period of the first Yugoslavia, articulated a mnemonistic theory of nationhood, by which 'the past (no matter how distant) is at one with the present'. ${ }^{149}$ For Šufflay, to be a Yugoslavist was to be an enemy of Croatdom because the Yugoslav idea distorted the relationship between past and present, threatening nationhood from within. ${ }^{150}$ Šufflay's vision was based upon the right to statehood that emanated from the territorial existence of the Croatian medieval state. 
A recurring theme in Banac's work was the idea that notions of Croatian nationhood derived from different traditions of thought that cannot be divorced from their historical context. This dissident account of national historiography had two key aspects that informed his political activism in the LS and challenged Franjoism. First, through his extensive historical work on the Croatian claim to historic statehood, it is possible to see how many opposition parties were able to argue that their programmes drew legitimacy from the state-rights tradition and a narrowly conceived conception of the historic statehood narrative. Banac argued that there were two aspects of Franjoism that appeared to contradict the historical statehood narrative as a basis for national identity, or at least as a basis of Tuðman's conception of what Croatian national identity meant. These were the HDZ's position on the role of the Catholic Church in the formation of Croatian national identity, and the citizenship question, both discussed earlier. The second key aspect of Banac's challenge to Franjoism was his rejection of the idea that there was a single tradition of thinking about the Croatian nation that could be inherited by Tuðman or any other political leader. Throughout his work, Banac located different writers in different traditions and constantly reminded us that these thinkers articulated different accounts of Croatian national identity. Banac's approach focused upon difference and dispute. Because of this he remained a dissident, described - as we saw earlier - as an enemy of Croatia.

Most of Slavenka Drakulićs ${ }^{151}$ early works were fiction novels and short stories. However, the collapse of communist Yugoslavia and the advent of war in Croatia prompted her to question the impact of these events on the lives of Croats, focusing especially on women's experiences. ${ }^{152}$ Drakulić's first major work of non-fiction was How We Survived Communism and Even Laughed. In the 1992 edition the author lamented the title of her work, observing that with the ascendancy of Tuðman, Milošević and war, 'we have not yet survived communism, and there is nothing to laugh about'. ${ }^{153}$ Viewed from Drakulić's perspective, the failure of communism in Yugoslavia could be attributed to its failure to provide for the basic needs of women, such as sanitary towels and make-up. This systemic failure made a mockery of the equation of socialism with emancipation and therefore alienated most women. ${ }^{154}$ However, there were no mass movements or protests demanding democracy. Instead, 'the 1989/90 revolution in Zagreb was a cautious, sour old lady who, awakened from half a century of sleep, found herself in a land she didn't know, among people who didn't know her. Democracy in Eastern Europe has a hundred faces, this one was sad and silent'. ${ }^{155}$

Drakulić was scathing and sarcastic in her treatment of Tuðman and the impact of his government, revealing once again the hollowness of the ruling party's claim to be all things to all Croats. According to Drakulić, Tuðman was neither politician nor diplomat, because 'he is too convinced of his historical mission to bother with such things' ${ }^{156}$ Such a view helps to explain the impunity with which he was able to commit diplomatic faux pas such his famous scribbling on a napkin. Quite simply, the President believed he did not need to 
engage in diplomatic and political niceties because of his historical role. ${ }^{157}$

Drakulićs understanding of the formation of Croatian national identity in the 1990s comprised four major components. These were: the politics of forgetting as a national prerequisite, the reduction of identity to the primacy of the nation, the complex relationship between patriotism and nationalism, and the role of civil society.

For Drakulić, the politics of remembrance and forgetting were interrelated. She chose to invert these processes, which underpinned the new nationalism in Croatia, by forgetting her Croatianness while remembering that which she should not - her prior Yugoslav identity. According to Drakulić, being Croatian bore no special meaning for many of the post-1945 generation. ${ }^{158}$ Commenting on items from the news of war, she described cases in which nationality was transcended by other forms of identities or emotions. One such case was that of Admira (a Muslim) and Boško (a Serb) who were shot by snipers while trying to flee Sarajevo. For them, too, 'nationality did not matter much: it could not decide their destiny, or prevent them from falling in love'. ${ }^{159}$ She argued that the nation claimed centre stage through processes of forgetting that seemed far removed from the remembering, resurrecting and reestablishing of the nation called for by Franjoism. Writing prior to the first Croatian elections in 1990, Drakulić warned that the possibility of forgetting should be guarded against particularly the possibility of forgetting the horrors of the past, such as the Ustaša. ${ }^{160}$ It was with little satisfaction therefore, that she noted that less than five years later the danger she had warned against - the danger of forgetting had come to fruition. The effect of this large-scale amnesia was that:

I feel ambiguous. I feel robbed of my past, my childhood, my education, my memories and sentiments, as if my whole life has been wrong, one big mistake, a lie and nothing else ... The Croatian 'new democracy' hasn't brought us anything yet but promises to believe in. The cost is high: renunciation of the whole past and sacrifice of the present. ${ }^{161}$

The process of forgetting that created a space for the new Croatian remembering, involved negating all that had happened in the previous 50 years. It involved the removal of communist stars from the graves of anti-fascist fighters as part of a process in which even the President's exalted communist past was forgotten. ${ }^{162}$ According to Drakulić, instead of being the continuation of a centuries-long dream, the creation of a Croatian national state was based on an entirely new narrative of identity. ${ }^{163}$ This identity did not begin with the medieval kingdom of Tomislav and Zvonimir but with the rise of Franjo Tuðman in 1990.

The forgetting of prior identity, accentuated by the war, led to a form of reductionism whereby all forms of identity were compressed into a single dominant identity, the nation. Drakulićs position on this matter was made clear by her observation that: 
Along with millions of other Croats, I was pinned to the wall of nationhood - not only by outside pressure from Serbia and the federal army but by inside national homogenisation in Croatia. That is what the war is doing to us, reducing us to one dimension: the Nation. The trouble with this nationhood, however, is that before I was defined by my education, my job, my ideas, my character and, yes, my nationality too. I am nobody because I am not a person any more, I am one of 4.5 Million Croats. ${ }^{164}$

Drakulić argued that Tuðman's Franjoist rhetoric was a form of reductionism that negated the identities of Croatian individuals, be it their gender, religion, class, education or profession. All this, she argued, was reduced to the central question of national identity. This reductionism was produced by two interrelated factors. On the one hand, it was produced by the ideology of the ruling party, which replaced the all-encompassing ideology of 'brotherhood-and-unity' with a new similarly all-encompassing ideology of the Croatian nation. According to this new ideology, in the new state of Croatia 'no one is allowed not to be a Croat'. ${ }^{165}$ Furthermore, Drakulić realised that this new ideology was given greater resonance by the war. It was the war, she claimed, that brought national ideology into the realm of the everyday. Reciting a conversation with her dentist, she recalled him stating that, 'the Serbs have turned me into a fierce Croat nationalist, a thing I was sure would never happen to me'. ${ }^{166} \mathrm{Had}$ the war not happened, we may speculate, Tuðman's national ideology might not have had the resonance that it came to assume in the day-to-day activities of Croats.

What most interested Drakulić was the impact of this reductionism on the experiences of women and the broader questions of gender and nationalism. ${ }^{167}$ In its most extreme form, nationalist reductionism produced the horrific crimes committed systematically by Serbs against Muslims and Croats in Bosnia and Hercegovina. ${ }^{168}$ The effects of identity reductionism on the lives of women in Croatia were generally subtler than this. Drakulić argued that '[in Croatia] women's lives, by no means spectacular, banal in fact, say as much about politics as no end of theoretical political analysis'. ${ }^{169}$ Under the dictates of communist ideology, women were considered to be both mothers and workers who were not much different from men. ${ }^{170}$ Under the new regime, however, women's identities were constrained in both overt and subtle ways. Franjoist clericalism led to the promotion of anti-abortion legislation and an interest in the role of women in reversing demographic decline.

Throughout her work, Drakulić observed practices in the day-to-day experiences of women that were affected by the new national ideology. One example was a campaign to persuade Croatian housewives to purchase goods that were made in Croatia. Women could instantly become patriots by doing this. On the other hand, if they purchased foreign goods they became a burden on the national economy and disappointed the war veterans whom they condemned to unemployment. By only buying Croatian goods though, women risked their domestic budgets because Croatian goods were considerably more expensive than imported goods. ${ }^{171}$ 
The third component of Slavenka Drakulićs engagement with national identity in 1990s Croatia was her claim that there was a tendency to confuse nationalism and patriotism. She argued that nationalism should be seen as an idea based upon the collectivisation of mass society in a way similar to communism. Patriotism on the other hand should be seen in terms of loyalty to a state based upon notions of citizenship and democracy. ${ }^{172}$ These two ideas 'were mixed up' by the war so that ideas of citizenship came to be imbued not with democratic notions of patriotism but with the ideas of mass society inculcated by nationalism. ${ }^{173}$ This mixing up accounted for the lack of distinction between government and people that was encapsulated by Franjoism. Thus patriotism was appropriated by the ruling party for its nationalist purposes, jettisoning ideas of democracy and citizenship and replacing them with ideas about loyalty to the party that were reminiscent of communism. ${ }^{174}$ The role of the dissident intellectual was to identify this confusion and articulate a vision of Croatian patriotism that invoked ideas of citizenship and democracy, since 'we [dissident Croatian intellectuals] believe that if you don't support the government, it doesn't mean that you don't support the Croatian people.'. ${ }^{175}$

The final strand of Drakulićs critique of national discourse raised questions about the development of civil society. She argued that one of the principal causes of the war and the reason why Croatia's political imagination was so easily colonised by the Franjoists, 'is that this society never had a proper chance to become a society not of oppressed peoples, but of citizens, of self-aware individuals with developed democratic institutions within which to work out differences. ${ }^{176}$ The rapidity of the shift from communism to independence to war meant that there was no time for a civil society based on patriotic ideas to develop. The idea of active citizenship therefore remained just that, an idea. Still, Drakulić argued, citizens believed (and were made to believe) that social change came from the top down, which meant that social movements in Croatia remained hesitant about mobilising people on issues such as human rights, the democratic deficit, or economic deprivation. ${ }^{177}$ The crux of the problem was that citizens - herself included - still looked to others to provide the engine for change rather than acting themselves. Extending this vision, she concluded that every Croatian citizen bore responsibility for the actions of the government because given the democratic nature of the new Croatia, in theory at least, every citizen had the opportunity (denied under communism) to take that responsibility. ${ }^{178} \mathrm{Of}$ course, the possibility for civic action was made more difficult by the politics of forgetting, the negation of non-national identities, and the confusion of patriotism and nationalism, all of which were actively encouraged by a government and state that permeated daily life no less than the communist state before it.

Drakulić focused on the realm of the personal. For her, Franjoist rhetoric was so powerful because it could reorient an individual's past and frame its destiny as part of a national body. She emphasised the intersection of the nation and the individual, highlighting a struggle between collective and individual identities. With the first three themes raised by Drakulić it appears that collectivism 
was unassailable, but by discussing the role of the individual in civil society she suggested a strategy for overcoming pernicious nationalism by separating out patriotism and nationalism. As with Banac, therefore, Drakulić understood the nation to be inscribed on the everyday and perceived Franjoism as something other than the manifestation of the will of the 'national body'.

A brief overview of two voices of dissent - Banac and Drakulić - therefore reveals disquiet with the Franjoist project. This disquiet was primarily expressed in two ways. First, the dissidents argued that Franjoism represented an untenable interpretation of the historical statehood narrative rather than constituting its zenith as it claimed. Banac provided intellectual credence to many of the claims articulated by opposition parties by exposing how national political programmes were historically framed as a political rather than ethnic or religious discourse. Furthermore, he convincingly challenged the idea that there was a unity of thought or common way of interpreting the historic statehood narrative in Croatian national thinking by precisely detailing different strands of thought that emerged from different social classes, historical epochs or regions. Thus civil Croatia developed within the classical European feudal order; Vojna Krajina developed as a peasant and warrior society; Dalmatia enjoyed Mediterranean forms of social organisation; Istria had both feudal and Mediterranean forms; while Hercegovina developed within the Turkish millet system. ${ }^{179}$ In this light, Franjoism can only be seen as a historically contingent construction rather than the manifestation of an abiding national truth.

The second way that these dissident voices raised disquiet with the Franjoist project was by describing the rupture with the past caused by the new national 'realities'. Drakulić highlighted the ways that forgetfulness was induced at the highest levels, while at the level of the everyday there were many points of resistance the resistance of remembrance. By drawing our attention to the everyday, Drakulić exposed the ridiculousness of Tuðman's rhetoric and lamented that in the transition from communism to 'democracy' very little had actually changed.

\section{Outside voices: the Croatian diaspora}

The final section of this chapter will briefly consider accounts of national identity articulated by elements of the Croatian diaspora, located primarily in Hercegovina, the USA, South America, Australia and Germany. ${ }^{180}$ Because their key claims were similar to those of 'Franjoism', they will be considered only briefly. The government attempted to persuade the Croatian diaspora to return to the 'homeland' for two principal reasons. First, it was argued that the economy badly needed the inward investment potential promised by the 'wealthy' diaspora. Second, it was argued that the worrying demographic situation in Croatia necessitated their return to inhabit under-inhabited regions such as the Adriatic islands. ${ }^{181}$ It should be noted, however, that despite their staunch nationalism, members of the diaspora were generally reluctant to return to Croatia. 
Of the various diaspora groups, by far the most prominent were the Hercegovinian Croats. Their role in launching a campaign to carve out a Croatian territory called Herceg-Bosna in Bosnia and Hercegovina has been well documented, as was the Tuðman government's support for the plan. ${ }^{182}$ According to Tuðman, Hercegovina was one of the pillars of Croatia and the Hercegovinian Croats were the pride of Croatia. ${ }^{183}$ Hercegovina - the cradle of Croatian extremism and the Ustaša movement - was not regarded so fondly in Croatia itself. Hercegovinian Croats were generally identified as extremists and criminals. This perception was made credible by Mate Boban, the one-time head of the $\mathrm{HDZ}$ in Bosnia and Hercegovina (HDZ-BiH) who ran a nationalist fiefdom in Herceg-Bosna, which he attempted to make nationally 'pure'. ${ }^{184}$ Many Croats from Croatia were embarrassed by atrocities committed by Bosnian Croats and the reluctance of the government to co-operate fully and unconditionally with the ICTY. ${ }^{185}$ This disquiet was fuelled by the financial influence of the Hercegovinian Croats on the HDZ. They profited greatly from the privatisation programme and formed a powerful lobby in the heart of the Croatian government. The Hercegovinian lobby was accused of operating in Mafia-like ways because corruption and violence were central components of their status within Croatia. ${ }^{186}$

The HDZ-BiH was the only Croatian party in Bosnia and Hercegovina to win significant support and its programme was very similar to that of the HDZ in Croatia. Its core policy was the protection of the 'interests' of the Croatian people of Bosnia and Hercegovina, which it defined narrowly as the protection of the language, religion, symbols and physical security of the Croats in Bosnia and Hercegovina. Although by 1995 it had come to subscribe publicly to the principle of Bosnia's territorial integrity, the party continued to call for the strengthening of ties with Croatia and subscribed to the idea of a confederation between the two states. ${ }^{187}$ This idea was supported by the HDZ in Croatia. ${ }^{188}$

Active extremism among the Croatian diaspora in Germany and Australia was most prominent in the time of Tito's Yugoslavia. In Germany, émigrés with links to the wartime Ustaša movement formed the Hrvatski Narodni Otpor (HNO - Croat National Resistance), under the leadership of Max Luburić, a former Ustaša general. Immediately after the Second World War, this organisation launched armed incursions into Yugoslavia. By the 1970s, Ustaša-type organisations had developed into terrorist groups that orchestrated bomb attacks in Yugoslavia and attacks on Yugoslav diplomats throughout the world. ${ }^{189}$ The HNO had a distinctly anti-Yugoslav persuasion:

[We] regard Yugoslavism and Yugoslavia as the greatest and only evil that has caused the existing calamity ... We therefore consider every direct or indirect help to Yugoslavia as treason against the Croat nation ... Yugoslavia must be destroyed - be it with the help of the Russians or the Americans, of Communists, nonCommunists or anti-Communists - with the help of anyone willing the destruction of Yugoslavia: destroyed by the dialectic of the word, or by dynamite - but at all costs destroyed. ${ }^{190}$ 
Other groups, such as the Ujedinjeni Hrvati Njemačke (United Croats of West Germany), Croatian Republican Party, Hrvatska Pravda (Croatia Justice), Fighters for a Free Croatia and the World League of Croat Youth articulated narratives similar to those of Franjoism, celebrating the memory of Croatian thinkers and activists such as Radić, Hebrang,and Starčević. ${ }^{191}$ Despite the large number of such groups, they did not achieve popularity among the Croatian diaspora. The principle reason for this was their perceived closeness to the Ustaša movement. These organisations were, to a large extent, orchestrated by participants in the NDH regime who had escaped Croatia in 1945. By contrast, the vast majority of Croatian migrants were economic migrants. The first wave of modern migrants had left Croatia in the nineteenth century, followed by greater numbers during the inter-war period and then again in the 1960s and 1970s. Many who settled in the West came into contact with liberal ideas for the first time and rejected the extremist claims of separatist groups. ${ }^{192}$

The best examples of non-Ustaša related émigré groups be seen by briefly considering associations set up by Croats in the USA. There are a large number of Croatian groups in the USA. The largest and most well known organisation is the Croatian Academy of America, which publishes its own journal, the Journal of Croatian Studies. Its mission statement declares that:

Inspired by the persistent desire of the Croatian nation for its proper dignity before all men, realizing that no people can make a responsible contribution towards a peaceful and democratic world without being freely self-determined i.e. endowed with the right to choose its own sovereign state, recollecting that Croatian liberty has been frustrated for centuries because of tyranny from without and within, conscious that the denial of freedom at home often requires the conservation of the national genius abroad, mindful that the friendly guardianship of the just aspirations of men has always been the keynote of American hospitality, we hereby establish and constitute The Croatian Academy of America. ${ }^{193}$

The Academy's primary purpose is to educate members and the general public about Croatia. Through this it hoped that the Croatian nation could eventually come to exercise its inherent right to self-determination. The distinction between this organisation and the radical separatist groups mentioned above can be uncovered by briefly examining the contents of the Journal of Croatian Studies. It is clear that there is a more expansive understanding of the Croatian nation and its position in Yugoslavia than that put forward by the radical separatists. The journal has published work on Croatian and Yugoslav literature and culture, dissident Croatian writers such as Vlado Gotovac, Croatia and America, language issues, and historical tracts on specific themes. As well as containing the work of well-known Croatian émigré nationalists such as Stephen Gazi and Vladimir Goss, the journal has also contained works on Croatia by non-Croats and those not normally considered to be Croatian nationalists, such as Ivo Banac. ${ }^{194}$ The Academy argues that education is the best approach to fulfilling Croatian self-determination and that this would be best served by debates that revealed the strength of the Croatian claim for that right. 
Many of the other Croatian American organisations are affiliated to the National Federation of Croatian Americans (NFCA). These include the Alliance of Croats of Bosnia-Hercegovina, the Croatian Benevolent Association, the Croatian Catholic Union, the Croatian Council, the Croatian Fraternal Union, the Croatian Fraternal Lodge, the Croatian National Association and the Federation of Croatian Societies. According to its statement of principles, 'the NFCA was founded to promote an independent, democratic, free market Croatia and Bosnia-Hercegovina'. Distancing the association from the radical separatists mentioned at the beginning of this section, its core principles also include the protection of human rights for all, regardless of nation, ethnicity or religion, the inviolability of the borders of Croatia and Bosnia and Hercegovina, and the promotion of co-operation between the two states. In case there is any question of whether the Federation is some kind of Ustaša cell, Principle 8 states that 'atrocities committed during World War II in the name of ethnicity and ideology by all parties in the former Yugoslavia are condemned and repudiated'. ${ }^{195}$ Unlike the Academy, the central objective of the NFCA is the promotion of Croatia in the USA and the strengthening of ties between the two societies. ${ }^{196} \mathrm{On}$ the question of political orientation, the NFCA maintains that it is independent from the government of Croatia and that it is not affiliated to any political party in Croatia. However, its mission statement insists that 'the NFCA will vigorously defend the Republic of Croatia when it is unfairly attacked'. ${ }^{197}$

There were therefore a number of traditions of thought about national identity within the Croatian diaspora after 1945. In the immediate aftermath of the Second World War, organised diaspora groups had links to the Ustaša members who had managed to evade Tito's purges. However, in recent years, the influence of Western political thought has become more discernible. Nationalist claims were elaborated with reference to ideas of self-determination and the idea of Croatia as a modern 'Western' democratic state was widely disseminated. However, this dissemination took place within an intellectual context where the central tenets of Franjoism were accepted and re-articulated. Furthermore, it was still possible to trace the roots of extremism to the diaspora, in the form of the former Defence Minister and ultra-nationalist Gojko Šušak for example.

\section{Competing voices of the nation}

The nation is a contested terrain of political discourse. The frames provided by the historical statehood narrative informed contemporary national narratives that in turn informed political discourse in the 1990s. Those same narratives and histories were mobilised in different ways to produce incompatible interpretations of the nation. However, as we saw in Chapter 2, the nation can be thought of as existing at different ontological sites. Hence, Slavenka Drakulić, for example, was able to locate the nation in the personal and day-to-day 
experiences of people and radically rewrite accounts proffered by political parties or diaspora movements that were located at the more abstract level of state policy.

The HDZ's Frajoist programme combined nationalist rhetoric and practical policy. At its core was the President, Franjo Tuðman. Tuðman was the central figure articulating Franjoism, and, given the high degree of presidential power wielded in the 1990s, he was also its main instigator. Franjoism insisted that national sovereignty and independence could only be achieved through national unity. Because the Franjoist project involved unifying a nation that was historically divided, Tuðman tried to be all things to all Croats. He failed to achieve his goal of national unification for at least two reasons. First, the rehabilitation of the diaspora and Croatia's fascists required policies and rhetoric that alienated many Croats in Croatia. Second, Tuðman had an idea of what 'his Croats' would look like. They would be 'ethnic Croats', who spoke a pure Croatian language and practised Roman Catholicism. As we shall see in the next two chapters, these ideas permeated government policy throughout the 1990s. Such a view of Croatian national identity represented a narrow and particularist interpretation of the historic statehood narrative rather than its embodiment.

Different political groups appealed to different aspects of the historical statehood narrative in order to legitimise their own political claims. This was attempted most blatantly by the modern Party of Rights (HSP) and the Croatian Peasants' Party (HSS) who both claimed a direct though tenuous lineage to their predecessors in the nineteenth and early twentieth centuries. These parties claimed that Tuðman did not adequately embody the national ideology put forward by the founding fathers of their traditions, Ante Starčević and Stjepan Radić. Other parties also attempted to locate themselves in Croatian political tradition. For example, the Social Democratic Party (SDP) traced its history back to a small social democratic movement that appeared in Zagreb at the very end of the nineteenth century. Although the liberals admitted that there was no ostensibly liberal tradition in Croatia they argued that this was because of the illiberal rule of imperial overlords. Thus they were able to discern traces of liberalism in the historical statehood tradition by claiming that this tradition was a citizen-based ideology. What was striking was that opposition parties (with the exception of the IDS) did not challenge the historical statehood narrative outlined in the previous chapter. Instead, they challenged the location of Franjoism within that narrative, seeing it as a particular interpretation of that tradition rather than its manifestation.

To look for accounts of national identity that challenged the historical statehood tradition, we need to turn to the works of dissident intellectuals. Ivo Banac's historical research showed that it is not accurate to speak of a single Croatian political tradition. Instead, Banac revealed a plethora of different traditions that were encouraged by the differing conditions and histories of Croatia's regions. Slavenka Drakulić shared similar concerns, and radically challenged Franjoism by discarding claims about a centuries-old dream. She argued that 
rather than being about remembering latent forms of intrinsic identity that had been suppressed by the communists, Franjoism was actually about forgetting the recent past. The Croatian national identity articulated by the new regime was entirely modern and entirely fabricated, Banac and Drakulić argued.

Our next task is to consider how these different ideas about national identity were manifested in contemporary social practice. The next chapters therefore address the question of the intersection of Croatian national identity with other social operators. As such, they locate debates about national identity within six different social settings and question whether the different ideas about national identity raised in this chapter had material resonance in social practice.

\section{Notes}

1 B. Anderson, Imagined Communities, revised edition (London: Verso, 1991), p. 6.

2 M. Billig, Banal Nationalism (London: Sage, 1991), p. 71.

3 Address by Dr Franjo Tuðman at the second session of the head committee of the HDZ held at the INA Building, Zagreb, 7 December 1996, p. 4.

4 H. Sosić, Croatian Political Dictionary (Rijeka: Tiskara Rijeka, 1993).

5 Feral Tribune, 29 December 1997, p. 6.

6 I. Tolj, N. Bičanić, K. Mujčić, For Croatia (Zagreb: Croatian Ministry of Defence, 1992).

7 F. Tuðman, Croatia at the Crossraods: In Search of a Democratic Confederacy (London: Centre for Policy Studies, 1991), p. 1.

8 Biographical details taken from M. Tanner, Croatia: A Nation Forged in War (London: Yale University Press, 1999), pp. 190-1.

9 B. Katich, So Speak Croatian Dissidents (Toronto: Ziral, 1983), p. 17.

10 A. Knezević, An Analysis of Serb Propaganda (Zagreb: Domavina TT, 1996), p. 5.

11 D. Owen, Balkan Odyssey (London: Indigo, 1996), pp. 78-9.

12 Tanner, Croatia: A Nation Forged in War, p. 224.

13 See I. Kearns, 'Croatian politics: democracy or authoritarianism?', paper presented to the Political Studies Association Conference on Eastern Europe, 1997.

14 Many of the themes mentioned below are also discussed by G. Uzelac, 'Franjo Tudjman's nationalist ideology', East European Quarterly, 31:3 (1998).

15 Guardian, 8 July 1995.

16 Feral Tribune, 17 November 1997.

17 Speech by Dr Franjo Tuðman on the seventh anniversary of the first convention of the HDZ, 23 February, 1997, p. 1.

18 See N. Zakošek, 'Political parties and the party system in Croatia', in I. Siber (ed.), The 1990/93 Sabor Elections in Croatia: Analysis, Documents and Data (Berlin: Edition Sigma, 1997), pp. 38-9.

19 F. Tuðman, Nationalism in Contemporary Europe (New York: Columbia University Press, 1981), p. 121.

20 Tuðman, Nationalism in Contemporary Europe, p. 122.

21 B. Buden, 'Culture and politics', ARKzin, November 1997. ARKzin is an independent magazine published in Zagreb by the anti-war movement (ARK). I am grateful to Boris Buden for forwarding copies of his work.

22 L. J. Cohen, Broken Bonds: Yugoslavia's Disintegration and Balkan Politics in Transition (Oxford: Westview, 2nd edition, 1995), p. 211. 
23 Tuðman, Nationalism in Contemporary Europe,, p. 174.

24 Tuðman, Croatia at the Crossroads, p. 14.

25 W. Zimmerman, Origins of a Catastrophe: Yugoslavia and its Destroyers (New York: Times Books, 1996), p. 72.

26 Tuðman, Nationalism in Contemporary Europe, pp. 124-8.

27 See I. Kearns, 'Croatian politics: the new authoritarianism', Political Quarterly, 67:1 (1996), 29.

28 M. Thompson, A Paper House: The Ending of Yugoslavia (London: Vintage, 1992), p. 269.

29 Tanner, Croatia: A Nation Forged in War, p. 222.

30 He died on 4 May 1998. See his obituary, I. Traynor, 'In the cause of Croatia', The Guardian, 5 May 1998.

31 F. Tuðman, Horrors of War: Historical Reality and Philosophy, revised edition, trans. K. Mijatović (New York: M. Evans and Co., 1997), p. 5.

32 Tuðman, Horrors of War, p. 33.

33 Tuðman, Horrors of War, p. 143. This same argument is made in F. Tuðman, Croatia on Trial (London: United Publishers, 1981).

34 Tuðman, Horrors of War, pp. 270-89.

35 Thompson, A Paper House, p. 268.

36 Tuðman, Croatia at the Crossroads, p. 8.

37 Feral Tribune, 8 December 1997.

38 Feral Tribune, 8 December 1997.

39 Feral Tribune, 29 December 1997.

40 Feral Tribune, 29 December 1997.

41 Feral Tribune, 29 December 1997.

42 Feral Tribune, 29 December 1997.

43 See R. M. Hayden, 'Constitutional nationalism in the former Yugoslav republics', Slavic Review, 51:4 (1992), 671.

44 F. Tuðman speech, 23 February 1997.

45 Operation Storm was a major Croation military offence launched in August 1995, which defeated Serb forces in the Krajina in three days.

46 Message from the President of the Republic of Croatia, Dr F. Tuðman, to Croatian Citizens of Serbian Nationality, 4 August 1995.

47 F. Tuðman, Address to the Nation, 17 November 1995.

48 D. Pleština, 'Democracy and nationalism in Croatia: the first three years', in S. P. Ramet and L. S. Adamovich (eds), Beyond Yugoslavia: Politics, Economics and Culture in a Shattered Community (Boulder: Westview, 1995), p. 282.

49 The Times, 7 August 1995.

50 L. Silber and A. Little, The Death of Yugoslavia (London, Penguin, 1995), p. 92.

51 Cohen, Broken Bonds, p. 96.

52 J. Lovrić, 'Tuðman will not give up on Herceg-Bosna', AIM Zagreb, 21 March 1997.

53 See, 'Tudjman $[$ sic $]$ party wins lukewarm triumph in Croat vote', Reuters, 30 October 1995.

54 Pleština, 'Democracy and nationalism', p. 134.

55 Feral Tribune, 4 May 1998.

56 E. Rehn, 'Report on the situation of human rights in the Republic of Croatia', United Nations Economic and Social Council, E/CN.4/1998/14, October 1997.

57 Rehn, 'Report', p. 14.

58 Rehn, 'Report', p. 14.

59 Article 3 of the Law of Citizenship stipulated that citizenship could only be granted on the grounds of one's origin, birth in the territory of the Republic of Croatia, naturalisation or international agreements.

60 Croatian Helsinki Human Rights Watch, Civil and Political Rights in Croatia (London: 
Human Rights Watch, 1995), p. 10.

61 I. Banac, The National Question in Yugoslavia: Origins, History, Politics (London: Cornell University Press, 1984), p. 68.

62 Tuðman, Nationalism in Contemporary Europe, p. 159.

63 F. Tuðman, 'Address of the President of the Republic on the State of the Nation', 15 January 1996.

64 See J. Lampe, Yugoslavia as History: Twice There Was a Country (Cambridge: Cambridge University Press, 1996), pp. 334-6.

65 Thompson, A Paper House, p. 283.

66 I. Mlivončić, 'St. Paul wouldn’t do it like that!!!', ARKzin, 59, 1 March 1996.

67 B. Magaš, The Destruction of Yugoslavia: Tracking the Break-up: 1980-92 (London, Verso, 1993), p. 256.

68 Silber and Little, The Death of Yugoslavia, p. 187.

69 See D. Glavas, 'The roots of Croatian extremism', Mediterranean Quarterly, 5:2 (1994), $47-50$.

70 L. J. Cohen, 'Embattled democracy: postcommunist Croatia in transition', in K. Dawisha and B. Parrott (eds) Politics, Power and the Struggle for Democracy in South-East Europe (Cambridge: Cambridge University Press, 1997), p. 109.

71 Reuters, 21 March 1996.

72 Hrvatski Obzor is a relatively new paper and was considered by many to be Tuðman's mouthpiece.

73 Hrvatski Obzor, 14October 1996.

74 BBC summary of world broadcasts, EE/D2453/A, Chatham House Library, London.

75 International Crisis Group, Change in the Offing: The Shifting Political Scene in Croatia, Brussels, 14 December 1998, p. 3.

76 Cohen, 'Embattled democracy', p. 78.

77 See Zakošek, 'Political parties', p. 35.

78 Tanner, Croatia: A Nation Forged in War, p. 256.

79 See M. Glenny, The Fall of Yugoslavia: The Third Balkan War (Harmondsworth: Penguin, 3rd revised edition, 1992), pp. 195-9.

80 Tanner, Croatia: A Nation Forged in War, p. 264.

81 Tanner, Croatia: A Nation Forged in War, pp. 265-7 and Cohen, 'Embattled democracy', pp. 95-7.

82 S. C. Markovich, 'Democracy in Croatia: views from the opposition', East European Quarterly, 32:1 (1998), p. 84.

83 Markovich, 'Democracy in Croatia', p. 84.

84 Brief History of SDP text provided by the office of Ivica Račan, leader of SDP, Zagreb.

85 Brief History of SDP.

86 Zakošek, 'Political parties', p. 42.

87 Zakošek, 'Political parties', p. 42.

88 On the attempted coup see Magaš, The Destruction of Yugoslavia, p. 323.

89 Zakošek, 'Political parties', pp. 42-3. The official argument is taken from documentation provided by Ivica Račan's office.

90 Magaš, The Destruction of Yugoslavia, p. 130.

91 I. Račan, 'Sketches of Croatia: transition inside transition', European Forum Newsletter, 19 (1998).

92 Račan, 'Sketches of Croatia', pp. 1-2.

93 Račan, 'Sketches of Croatia', pp. 1-2.

94 Račan, 'Sketches of Croatia', p. 1.

95 D. Curić, 'The SDP and the socialist international', Croatia Weekly, 29 May 1998.

96 B. Denitch, Ethnic Nationalism: The Tragic Death of Yugoslavia (London: University of Minnesota Press, 1994), p. 141. 
97 Tjednik, 12 December 1997.

98 I. Sabalić, 'Authoritarianism in Croatia and prospects for change', New Politics, 1 (1994), 77.

99 Sabalić, 'Authoritarianism in Croatia', 77.

100 Sabalić, 'Authoritarianism in Croatia', 78.

101 Zakošek, 'Political parties', p. 45.

102 Zakošek, 'Political parties', p. 45.

103 HSLS, 'The basic principles of the Croatian Social Liberal Party'. Documents from the HSLS were provided by Stjepan Redulić, assistant to the Secretary-General of the HSLS.

104 HSLS, 'The basic principles'.

105 Sabalić, 'Authoritarianism in Croatia', pp. 80-1.

106 Woodward, Balkan Tragedy: Chaos and Dissolution after the Cold War (Washington DC: The Brookings Institute, 1995), p. 345.

107 Tanner, Croatia: A Nation Forged in War, pp. 194-201.

108 D. Budiša, speech delivered at the Seventh Congress of the HSLS, Zagreb, 29 November 1997.

109 Budiša, speech delivered at the Seventh Congress', pp. 2-4.

110 Feral Tribune, 1 September 1997.

111 Tjednik, 5 December 1997.

112 V. Gotovac, F. Tuðman and M. Veselica, Letters Against the Tyranny (London: United Publishers, 1981).

113 V. Gotovac, interview given to Dutch programme Nieuwsnet, in Katich (ed.), So Speak Croatian Dissidents, p. 59.

114 ' 21 topics for Croatia on the eve of the 21 st century', declaration of the founding congress of the Liberal Party, 28 January 1998.

115 '21 topics for Croatia'.

116 Programme of the Liberal Party, Zagreb, 24 January 1998, pp. 6-7.

117 The HSS formed an 'economic union' for peasants. V. Maček, In the Struggle for Freedom, trans E. Gazi and S. Gazi (London: Pennsylvania State University Press, 1957), pp. 169-71.

118 Zakošek, 'Political parties', p. 46.

119 Zakošek, 'Political parties', p. 46.

120 Marković, 'Democracy in Croatia', pp. 85-6.

121 Cohen, 'Embattled democracy', p. 99.

122 Cohen, 'Embattled democracy', p. 99.

123 Thompson, A Paper House, p. 89.

124 Woodward, Balkan Tragedy, p. 345.

125 Markovich, 'Democracy in Croatia', p. 87.

$126 \operatorname{AIM}$ (Zagreb), 18 September 1998.

127 K. Verdery, 'Introduction', in I. Banac and K. Verdery (eds), National Character and National Ideology in Interwar Eastern Europe (New Haven: Yale Center for International and Area Studies, 1995), p. Xv.

128 I. Banac, 'Introduction to special issue on the concepts of nationhood in early modern Eastern Europe', Harvard Ukrainian Studies, 10:3-4 (1996), 274.

129 Ivo Banac is a Professor at Yale University and the Central European University in Budapest. He is a regular contributor to Feral Tribune and was Vice-President of the Croatia Helsinki Human Rights Watch and the Liberal Party (LS).

130 See also I. Banac, 'The fearful asymmetry of war: the causes and consequences of Yugoslavia's demise', Daedalus, 119:1 (1992).

131 I. Banac, 'Post-communism and post-Yugoslavism: the Yugoslav non-revolutions of 1989-90', in I. Banac (ed.), Eastern Europe in Revolution (London: Cornell University Press, 1992), p. 180. 
132 Hrvatsko Slovo, 14 February 1997.

133 Hrvatski Obzor, 14October 1996.

134 Banac, The National Question in Yugoslavia, p. 74.

135 Banac, The National Question in Yugoslavia, p. 74.

136 Banac, The National Question in Yugoslavia, p. 75.

137 Banac, The National Question in Yugoslavia, p. 76.

137 Banac, The National Question in Yugoslavia, p. 76.

139 Ivo Banac, The National Question in Yugoslavia, pp. 66-7.

140 Banac, The National Question in Yugoslavia, p.108.

141 Banac, The National Question in Yugoslavia, p. 106.

142 Banac, The National Question in Yugoslavia, p. 72.

143 I. Banac, 'Ministration and desecration: the place of Dubrovnik in modern Croat national ideology and political culture', in I. Banac, J. G. Ackerman and R. Szporluk (eds), Nation and Ideology: Essays in Honor of Wayne S. Vucinich (New York: East European Monographs, 1981), p. 151.

144 Banac, 'Ministration and desecration', p. 160.

145 See I. Banac, 'Emperor Karl has become a Comitadji: the Croatian disturbances of 1918', Slavonic and East European Review, 120:1 (1992).

146 See I. Banac, 'The redivived Croatia of Pavao Ritter Vitezović', Harvard Ukrainian Studies, 10:3-4 (1986), 497.

147 Banac, 'The redivived Croatia', p. 500.

148 Banac, 'The redivived Croatia', p. 500. The significance of the claim for Croatian reunification is outlined in M. Gross, 'The union of Dalmatia with northern Croatia: a crucial question of the Croatian national integration in the nineteenth century', in M. Teich and R. Porter (eds), The National Question in Europe in Historical Context (Cambridge: Cambridge University Press, 1993), pp. 270-92.

149 I. Banac, 'Zarathustra in red Croatia: Milan Šufflay and his theory of nationhood', in Banac and Verdery (eds), National Character and National Ideology, p. 183.

150 Banac, 'Zarathustra in Red Croatia', pp. 187-93.

151 Slavenka Drakulić was born in Rijeka in 1949 and read comparative literature and sociology at the University of Zagreb. She is a respected journalist and commentator on the affairs of the former Yugoslavia and regularly writes in the New Statesman, the New Republic, the Guardian and The Nation. She was the co-founder of the first feminist group in Yugoslavia in 1979 and a founding member of the East European women's group network.

152 Slavenka Drakulić's most renowned works of fiction are: Holograms of Fear (London: The Women's Press, 1987); Marble Skin (London: The Women's Press, 1994); and The Taste of a Man (London: Hutchinson, 1997).

153 S. Drakulić, How We Survived Communism and Even Laughed, 1992 edition (London: Vintage, 1992), p. xix.

154 Drakulić, How We Survived Communism, p. 30.

155 Drakulić, How We Survived Communism, p. 143.

156 S. Drakulić, Café Europa: Life after Communism (London: Abacus, 1996), p. 192.

157 S. Drakulić, 'Mapped out: a Tudjman [sic] fantasy', New Republic, 213:11 (1995), 14-15.

158 S. Drakulić, The Balkan Express: Fragments From the Other Side of War (London: Harper Perennial, 1992), p. 50.

159 S. Drakulić, 'Love story: a true tale from Sarajevo', New Republic, 209:17 (1995), 14-16.

160 Drakulić, How We Survived Communism, p. 40.

161 Drakulić, Balkan Express, p. 58.

162 S. Drakulić, 'Memories of the Tito regime: my fatherland', New Republic, 212:6 (1994), $15-17$.

163 See S. Drakulić, 'Afterword' in D. Karahasen, Sarajevo: Exodus of a City (London: Kodansha International, 1993), p. 113. 
164 Time Magazine, 20 January 1992.

165 Drakulić, Balkan Express, p. 52.

166 Drakulić, Balkan Express, p. 14.

167 Issues produced by the nationalism-gender nexus in Croatia were also dealt with by L. Gjurgjan, 'Nationalism and women in Croatia', Journal of Gender Studies, 1:4 (1992).

168 The mass rape of women was also a feature of the 1991 Serb-Croat war. See S. Drakulić, 'Mass rape in Bosnia - women hide behind a wall of silence', The Nation, 1 March 1993; B. Allen, Rape Warfare: The Hidden Genocide in Bosnia-Hercegovina and Croatia (London: University of Minneapolis Press, 1996); and A. Stiglmayer (ed.), Mass Rape: The War Against Women in Bosnia-Hercegovina (London: Pinter, 1993).

169 Drakulić, How We Survived Communism, p. xxiii.

170 Drakulić, How We Survived Communism, pp. 23 and 88.

171 Drakulić, Café Europa, p. 113.

172 'Interview with Drakulić', recorded in N. Ceh and J. Harder (eds), The Golden Apple: War and Democracy in Croatia an Bosnia (New York: Columbia University Press, 1996), pp. 34-9.

173 'Interview with Drakulić', p. 36.

174 'Interview with Drakulić', pp. 36-7.

175 'Interview with Drakulić', p. 38.

176 Drakulić, The Balkan Express, p. 13.

177 Drakulić, Café Europa, p. 117.

178 Drakulić, Café Europa, pp. 96-9 and pp. 140-2.

179 M. Gross, 'On the integration of the Croatian nation: a case study in nation building', East European Quarterly, 15:2 (1981), 210.

180 On two of the more obscure places of origin for the Croatian diaspora, see D. M. Pavičić, Croats in Chile: Biographies (Zagreb: Nacionalna i Sveučilišna Knjižnica, 1998) and I. Grabovac (ed.), 450 Years of Croatians in Canada (Calgary: Croatian Studies Foundation, 1995).

181 These arguments were put to the author by Bert Parač, Head of Membership of the HDZ in an interview carried out in Zagreb, 15 April 1999. The myth of the economic wealth of the diaspora is strongly disputed by economists such as Nevenka Čučković at the Institute of International Relations, Zagreb.

182 Dispatches: A Greater Croatia, Channel 4, first screened on 5 January 1994.

183 J. Lovrić, 'Tudjman [sic] will not give up on Herceg-Bosna', AIM, 21 March 1997.

184 Tanner, Croatia: A Nation Forged in War, pp. 286-7.

185 Nedjelna Dalmacija, 1 February 1996. The opposite view can be found in Feral Tribune, 24 November 1997. For a personal account of the Ahmiči massacre, see B. Stewart, Broken Lives: A Personal View of the Bosnian Conflict (London: Harper Collins, 1993), pp. 278-99.

186 Feral Tribune, 8 April 1996.

187 Political programme of the HDZ-BiH, forwarded to the author by the General Secretariat of HDZ-BiH in Mostar, October 1998.

188 Independent, 5 August 1992.

189 S. Clissold, 'Croat separatism: nationalism, dissidence and terrorism', Institute for the Study of Conflict Paper No. 103 (London: Institute for the Study of Conflict, 1979), pp. $5-10$.

190 Der Spiegel, 5 June 1978.

191 For a more detailed analysis of these groups see S.Clissold, Croat Separatism.

192 L. Shaw, Trial by Slander (Canberra: Harp Books, 1973).

193 Preamble to the Constitution of the Croatian Academy adopted 19 April 1953, in New York. 
194 I. Banac, 'Comments', Journal of Croatian Studies, 27 (1986); S. Gazi, 'Beginning of the Croatian Peasant Party: a historico-politico study', 3-4 (1962-3); V. Goss, 'The beginnings of Romanesque architecture in Croatia', 18-19 (1977-78); D. Porter, 'New observations on Ivan Mestrović, Journal of Croatian Studies, 24 (1983).

195 Statement of Principles of the National Federation of Croatian Americans.

196 NFCA, 'Croatian Americans: making a difference': pamphlet produced in 1998.

197 NFCA, 'Croatian Americans'. 


\section{The nation in social practice I Economy, football and Istria}

The following two chapters assess the way that the disputes about the meaning of Croatian national identity in the 1990s (discussed in the previous chapter) were manifested in a variety of social practices. This third level of abstraction is concerned with how competing conceptions of national identity (Chapter 4) that make use of abstract frames (Chapter 3) are manifested and embedded in social practice and in identifying sites of resistance to the national 'common sense'. The six brief studies contained here reveal the nation to be a terrain of political competition in which the state is but one, albeit powerful and well resourced, protagonist. Such disputes take place not only among political and intellectual elites but also within a diverse range of social practices. The focus here then is on how interpretations of the historical statehood narrative are manifested in the identities that inform social practices. These chapters ask how competing ideas about Croatian national identity are manifested in different areas of social activity by considering the resonance and reinterpretation of abstract ideas in six areas of social activity.

In each of these areas the 'nationalising state' attempted to enforce the Franjoist conception of national identity articulated in the previous chapter. However, there were also radical reformulations of nation identity manifested in social practice. Although the government was successful in enforcing its own account of national identity in some areas, such as the education system, alternative accounts flourished in others, such as sections of the economy and the senior hierarchy of the Catholic Church. The contest can be understood as a series of attempts by the ruling elite to embed Franjoism in the everyday activities of Croats and practical resistance to such attempts. Sometimes this resistance drew on the ideas discussed in the previous chapter, sometimes they reinterpreted Franjoism, and sometimes they drew upon other influences. 


\section{The national economy}

Most Croatian papers on the economy in the 1990s begin with a caveat: all the problems that the economy faced were exacerbated by the 1991-95 war. This caveat was important to the government because one of the central claims made by Croatian dissidents during the Yugoslav period was that Croatia's natural economic strength was stifled by so-called 'Yugo-communism'. Marko Veselica, imprisoned after the 1971 purges, argued that the Croatian economy was held back by Yugoslavia because 'political instead of economic priorities determine the allocation of development capital', a wasteful exercise since '[e]ven though Montenegro has invested twice as much into the means of production per worker as compared to Croatia, its accumulation per worker is less than one third that in Croatia'. ${ }^{1}$ He argued that the Yugoslav economic system had a particularly negative effect on Croatia because of Croatia's Western-oriented economy. ${ }^{2}$ Other problems included the bureaucratic manner in which infrastructure projects were decided upon. A more oft-repeated argument was that Yugoslavia 'stole' the foreign currency income earned by Croatian tourism and Croatian gasterbeiter (guest workers) in Germany. ${ }^{3}$

Because economic claims played a significant role in legitimising Croatian independence, an external reason had to be found to explain why Croatia did not become a 'Balkan tiger' after independence. This is why virtually every official Croatian tract on the economy in the 1990s began with a list of war damages, apportioning blame for the failure of the economy upon external enemies. This is not to say that the economy was not badly damaged by the 1991-95 war. It is estimated that direct war damages in Croatia amounted to $\$ 43$ billion, that industrial output decreased by around 39 per cent, and that provision for more than a million refugees cost an additional $\$ 1.3$ billion or around one-fifth of the gross domestic product (GDP) in 1992. As a result of war damage on industry, the GDP in 1992 was less than half the 1989 GDP. The economic situation was made worse by the decision of the Croatian National Bank (Hrvatska Narodna Bank - HNB) to finance the 1991 war by printing Yugoslav banknotes, which inadvertently helped to fund the Serbian war effort through the cross-border transfer of notes, which was still possible prior to the 1991 ceasefire. ${ }^{5}$ In 1992 inflation reached 765.5 per cent and in 1993 it rose to 1,617.5 per cent, before the implementation of the stabilisation policy. ${ }^{6}$

The revival of the national economy was a key aspect of the government's policy and fulfilled an important role in legitimising the government's conception of national identity. According to Dragomir Vojnić, a Zagreb economist, 'the fundamental objectives of the economy and policy of transition consists in re-establishing the ties with some essential historical and civilisational trends that were broken by socialism'. ' Such trends, Vojnić argued, included plurality of ownership and political pluralisation. Furthermore, 'transition will encompass all spheres of the human lives and human relations, including the most subtle areas in the realm of the ideology, religious and other segments of the 
social conscience'. ${ }^{8}$ Similarly, the Ministry of Development and Reconstruction argued that economic reform would lead to the 'revitalisation of the Croatian cultural and humanistic values, especially humane and educational values'. The transition to a market economy was therefore perceived as part of a wider social transition and a return to the 'roots' of traditional Croatian commercial practices, which bore greater resemblance to those of Western Europe than those of Balkan communism. Failures within the economy were explained away as the handiwork of Croatia's enemies. As Marko Škreb, Governor of the HNB warned, 'one should never forget the vested interests in the economy [communists and Serbs] and their resistance to change'. ${ }^{10}$

The first major attempt to redirect the new national economy was the stabilisation programme in $1993 .{ }^{11}$ It attempted to curb inflation by abandoning the former currency and introducing the Croatian Kuna currency. This was accompanied by an austerity programme that limited government spending and directed it almost totally towards funding the war. This meant that other areas of the public sector, such as education and infrastructure, were starved of cash for long periods and public sector workers went without pay for long durations. In monetary terms, the stabilisation programme was a success. Inflation was lowered to 0.6 per cent and remained low for the rest of the decade, providing a source of national pride. Economists often pointed to the favourable comparison of Croatian inflation with that of other transition economies. ${ }^{12}$ This linking of neo-liberal and nationalist objectives (low inflation is a neo-liberal aim and demonstrates that Croatia is different from other Balkan states) won the approval of foreign economists. ${ }^{13}$

Two cases were frequently cited as instances of economic success and justification for the stabilisation programme: the success of the Ericsson Nikola Tesla telecommunications company and the partially privatised Croatian Post and Telecommunications Corporation (HPT). Not only did Ericsson Nikola Tesla achieve large profits (despite laying off many workers), it also helped to create and develop the Zagreb stock exchange. At the end of the 1990s, a decline in its fortunes was ascribed solely to the Russian economic crisis. ${ }^{14}$ HPT was split into its postal and communication functions for full privatisation, but remained the only profitable state business. In 1998 it achieved profits of $\$ 79.4$ million, a unique achievement among state industries throughout the former communist world. According to the government, HPT owed its success to a massive investment programme (the government estimated that 80 per cent of HPT's equipment was new), economic stability, and a Western-oriented business ethos. However, other factors in the success may have included its virtual monopoly position, its access to investment funds appropriated from its banking activities, and large reserves accumulated during the Yugoslav era. ${ }^{15}$

The single most important aspect of the stabilisation programme was the introduction of the Kuna currency. Many nationalist-minded Croatian historians and economists argued that 'Croatia's currency has an old and distinguished history'. ${ }^{16}$ They pointed out that the Kuna had been a symbol of the Croatian 
people since its first known usage in 1256. Contrary to those who argued that the currency had a fascist heritage, they argued that during the Second World War the Kuna was the currency of both the Ustaša and the Croatia Partisans, who issued bonds in a denomination called Dinar-Kuna. This dual role made the Kuna an important symbol of Tuðman's national unification campaign. The Kuna was used to portray many things about contemporary Croatia. The currency became a symbol of stability and continuity. ${ }^{17}$ This stability was attributed to the international credibility it gained from the fact that each Kuna was backed by equivalent HNB holdings of foreign currency. ${ }^{18}$ According to the Governor of the HNB, 'the introduction of the Kuna was a political event that led to economic stability' and 'added credibility to reform and national pride'. ${ }^{19}$ This national pride was heightened by the fact that the HNB produced Kuna coins rather than just paper currency, symbolising the stability of the economy and the finality of the transition from the inflationary Yugoslav economy.

However, these currency reforms were closely linked to flawed banking reforms through which Croatia tried to establish a Central European banking system but instead established a network of unprofitable and corrupt banks with close links to the HDZ. Prior to the transition, Croatia had two main state banks: Privredna Banka, which was linked closely to the League of Communists and JNA, and Zagrebačka Banka. ${ }^{20}$ Banks in socialist Yugoslavia had a peculiar and distinctive role. Generally funded by local political elites and enterprises, the bank's primary role was to support the local economy. The bank's founder, who was often also the head of a local enterprise and the local party, distributed profits and loans. ${ }^{21}$ As such, when banks were privatised at the beginning of the 1990s, the main shareholders were the enterprises that were also the main customers. Therefore, as Kraft and George argued, 'banks have been privatised to the extent that their shareholders have been privatized'. ${ }^{22}$ After the liberalisation of banking there was an explosion in the number of banks so that by the end of the 1990s there were around forty. Although the majority of these banks were privately owned, the five banks that remained in state ownership controlled around three-quarters of the total market share.

The main problem with the banking system was that there were too many banks that lacked a solid financial base. This meant that they frequently collapsed. Many Croats lost their savings because there was only a weak system of checks and safety nets. ${ }^{23}$ Critics argued that Croatian banks were responsible for a 'grand theft' and for maintaining a communist-style economy in which some people became very rich while the majority remained impoverished. One famous case was that of the collapse of Dubrovačka Banka. As with most banks in Croatia, this bank was run by people close to the HDZ who handed out millions of Kuna in so-called 'sweetheart loans'. These loans were often unsupported loans awarded to HDZ colleagues to allow them to buy businesses through the privatisation programme. As Ivo Bičanić explains, "[Sweetheart loans] are part of a completely untransparent system by which top managers receive large loans from banks (whose managers are their established business 
partners and often friends). Sometimes the banks accept as collateral the shares themselves, overvalued real estate, or frozen 'foreign currency savings'. ${ }^{24}$

As more often than not the borrowers were unable to repay the loans, Dubrovačka Banka was unable to meet its savers demands and had to be bailed out by the HNB. ${ }^{25}$ The general distrust of the banking system that this produced was exacerbated by the national bank's failure to regulate such corrupt practices. As Bruno Schonfelder pointed out, 'any attempts to enforce some standards of sound banking would be bound to run up against the powerful interests represented by the major publicly owned banks, some of which clearly engage in shady business'. ${ }^{26}$ Večernji List reported that in response to claims of corruption in Croatian banks, the Finance Minister Borislav Škegro launched an investigation into four banks that resulted in criminal charges being brought against 109 people. ${ }^{27}$ It is not surprising therefore that many Croats did not consider the economic system to be the source of national pride intimated by Marko Škreb.

A core element of the economic transition, and a key part of the stabilisation programme, was the privatisation process. The Croatian privatisation law, which was passed in July 1992, built on reforms embarked upon two years earlier by the then Yugoslav President, Ante Marković. By doing this, the Croatian government gained the advantages of a progressive programme and culture of reform but also adopted the peculiarities of the Yugoslav privatisation initiative that strengthened the iniquities inherent within it. ${ }^{28}$ In particular, the Yugoslav legacy gave the government the opportunity to build an extensive state-owned sector and passed on an 'imperfect' privatisation concept that retained a substantial degree of so-called 'social ownership'. ${ }^{29}$ The legacy of social ownership, coupled with the widespread phenomenon of 'sweetheart loans' mentioned above, meant that many companies were privatised without any investment capital and were sold to individuals who had no intention (or means) of providing such capital. ${ }^{30}$ Nevertheless, the government often proclaimed the success of privatisation, claiming that with each successful privatisation 'Croatia comes closer to Europe'. ${ }^{31}$

Another important aspect of the privatisation programme was the return of, or compensation for, property confiscated by the communist authorities after 15 May 1945. The compensation was theoretically available to all those who were citizens of Croatia in August 1996. It was aimed at providing redress for Croats who had left Croatia in 1945 (many with Ustaša connections) but was extended to include Jews (but not Serbs) who had property confiscated by the NDH during the Second World War. ${ }^{32}$ Although the state could not afford to compensate every Croatian citizen who had property confiscated by the communists, this legislation demonstrated that privatisation was viewed both as a way of breaking down communist structures in Croatian society and as a way of emphasising that communism had always been an alien concept for the Croatian people. Importantly, it also aimed to reinforce the unification process by insisting that all Croats had suffered through the confiscation of property at one time or other. 
Far from uniting the nation in a great march to a privatised economy, however, the government's handling of the process alienated large sections of society. According to the Liberal Party (LS) leader and former Yugoslav dissident, Vlado Gotovac, the privatisation programme was a 'grand theft from the Croatian people', because socially owned industries were sold cheaply to friends of the government through the extensive use of 'sweetheart loans'. ${ }^{33}$ As early as 1992, the HSLS tabled a thirteen-point reform plan for privatization, and a few months later the HSS also tabled a motion in the Sabor condemning corruption. ${ }^{34}$ The SDP, meanwhile, insisted that upon election to government its first priority would be to root out all the corrupt 'cronies of the HDZ, who have become rich while the rest of Croatia suffers' ${ }^{35}$ In February 1993 the generally government-friendly (and most widely read) daily newspaper, Večernji List, published an opinion poll on privatisation. Contrary to seeing privatisation as a source of national pride, 43.6 per cent of respondents declared that they were dissatisfied with the programme compared with 18.9 per cent who declared satisfaction. Additionally, 57.3 per cent of respondents supported demands for a parliamentary debate on the issue (only 9.8 per cent did not).

The HDZ secured a large part of the 'private' economy for its members through privatisation. It was able to put itself in positions of economic power in regions (such as Istria) where it lacked local political power. Moreover, because of the problem of a general lack of solvency throughout the economy, 'a good portion of the economy [was] still owned by the government'. ${ }^{36}$ Thus, the state retained control of the strategically vital Tisak newspaper kiosk group and the Skolska Knijžara (school book) shops.

Despite the obvious flaws with its handling of the privatisation programme, the government was keen to extol its virtues and make grandiose claims for it. This included emphasising that transition meant a return to traditional Croatian economic values embedded in the historic statehood narrative and distanced Croatia from economic practices in the communist Balkans. To support this claim, much was made of cases where the policy of national unity produced economic dividends. One of the most often used cases was that of the Karlovačko Pivovara (Karlovac brewery), which was revived thanks to a large injection of cash from Jaime Guerrero Devlahovich. Devlahovich, a Croatian émigré from Chile, returned to Croatia to invest DM15.3 million in the brewery, which expanded its operations as a result. ${ }^{37}$

The Croatian Investment Promotion Agency (CIPA) was formed explicitly to promote the image of the economy as a dynamic 'Western' one. CIPA had responsibility for attracting foreign investment by promoting Croatia's economic virtues both abroad and domestically. To accomplish its task, the agency deployed two tactics. First, it attempted to show that the Croatian economy was similar to Western liberal economies and in particular the economies of Central Europe (Austria and Hungary). It insisted that because of its 'basis of low inflation and conservative fiscal policy, the structure of the Croatian economy is similar to that of other developed economies'. ${ }^{38}$ Furthermore, CIPA pointed out 
that for investment purposes Croatia was internationally classified in the same group as Greece, Hungary and Poland. ${ }^{39}$ CIPA emphasised the fact that by the end of the 1990s over half of Croatia's foreign trade was carried out with members of the European Union (mainly Austria, Germany, and Italy), and that a further 20 per cent of trade was conducted with the members of the Central European Free Trade Area (CEFTA).$^{40}$

The second strategy was to stress the extent to which Croatian culture and history created a natural Western tendency within the economy. CIPA listed seven reasons why foreign investors should invest in Croatia, each of which was designed to emphasise the Western (and decidedly un-Balkan) orientation of the economy. These were: a stable and democratic political environment, a stable economy with low inflation, a favourable legal framework for foreign investors, a fast growing market, a skilled and well-educated workforce, a favourable geopolitical position, and a friendly environment for foreign investment. ${ }^{41}$ The Chamber of Economy added several other factors, including a Croatian tradition of entrepreneurship, another tradition in conducting international business, and a historical legacy of innovation. ${ }^{42}$ With all these facets and traditions, the Croatian economy was thought to be successfully disengaging itself from the alien economics of self-management socialism, re-engaging with its 'natural' partners in Central and Western Europe and re-establishing Croatia's 'natural' patterns of economic activity that were suppressed during the Yugoslav period. Because of this, the President of the Croatian Chamber of Economy, Nenad Vidošević, declared that 'Croatia can say that it has met the preconditions for economic prosperity', ${ }^{43}$ while the Governor of the HNB observed that 'Croatia has been a remarkable success story among transition countries'. ${ }^{44}$ The idea that Croatia's commercial tradition lay in trade with Central and Western Europe drew upon the historic statehood narrative that emphasised that Croatia's historic links were with Austria and Hungary, not Serbia.

However, this view of the success of the national economy was not one that was widely shared outside governmental and economic elites. Low wages, high prices, high unemployment and a reduction in the standard of living from that enjoyed in 1980s Yugoslavia led many people to question whether independent statehood, coupled as it was with a presumed increase in the quality of life, had actually made life better. As we saw earlier, the agencies of economic governance in Croatia insisted that any economic problems the country confronted in the 1990s were caused by 'vested interests' (communists) and the Serbian attack on Croatia. However, as official unemployment approached 20 per cent, GDP stagnated and the economy actually shrank after the war, such arguments had little resonance with large sections of the population.

The most pressing problem was that while wages remained at 1980s levels, with an average gross wage in 1998 standing at 3,555 Kuna per month (around $\$ 450$ ) and GDP per capita at $\$ 4,227,{ }^{45}$ prices increased sharply. This dramatically reduced the standard of living. A prices index published by the Central Bureau of Statistics demonstrates the dramatic nature of this change. Remembering that 
average wages were very similar in 1997 to what they were in the 1980s, the cost of living index (taking 1993 as the base of 100) had reached 234 by 1997. Thus even in the four years after the implementation of the stabilisation programme prices more than doubled, while wages remained static and unemployment increased. ${ }^{46}$ The change in currency meant that this increase was hidden from the inflation figures, which had become meaningless by 1993. Also, this came after the main fighting in the Serb-Croat war, and two of the four years covered by this index were after the Dayton Agreement had put an end to the war in Bosnia as well. Željko Rohatinski speculated that this disjuncture between prices and wages explains why inflation in post-stabilisation programme Croatia remained so low. High prices and low wages meant that demand for products did not grow and this lack of economic activity prevented further inflation. ${ }^{47}$ This is a somewhat different explanation from those offered by the HNB and CIPA discussed earlier.

This disjuncture produced two economic practices that undermined the official characterisation of the national economy. One the one hand, long standing bills for services were paid only infrequently. It was estimated that in 1996 there was about 8 billion Kuna of unpaid bills and that this figure was increasing at a rate of 2 billion Kuna per year. ${ }^{48} \mathrm{~A}$ substantial amount of this debt (1.2 billion Kuna) was owed in unpaid bills to the Croatian state electricity company, showing the effect of the price-wage inconsistency on household economies. ${ }^{49} \mathrm{~A}$ second common practice was engagement with the unofficial economy. A conservative estimate suggested that about one-quarter of all economic transactions in late 1990s Croatia were unofficial..$^{50}$ 'Unofficial transactions' meant people working unofficially and transactions not being officially recorded. Around 54,000 people were believed to be engaged in unofficial employment. ${ }^{51}$ However, there was also a significant number of people who did not work but who also did not claim the meagre unemployment support offered by the state and hence did not appear in unemployment statistics. Moreover, there were no official statistics to show the number of people who were technically in employment but did not receive regular wages or had not been paid for a considerable period of time..$^{52}$ The significance of the unofficial economy increased in the last two years of the 1990s thanks to the introduction of a new value-added tax (PDV) of 22 per cent on all products purchased or brought into Croatia. Ostensibly designed to bring the Croatian taxation system into line with European tax systems, the imposition of this tax increased black market participation. ${ }^{53}$ Interestingly, the government did little to stem the tide of the unofficial economy, despite the unoffical economy casting doubt on to the government's claims about the national economy. According to the Chamber of Economy, the government recognised the fact that the unofficial economy alleviated the fall in the standard of living caused by the disjuncture of wages and prices and thus 'protected the state from excess social unrest'. ${ }^{54}$ Although the government legislated against the unofficial economy, it only employed 74 inspectors to enforce it..$^{55}$

Thus one of the main legitimating claims put forward by Croatian nationalists in support of independence was that the Croatian economy was 
adversely affected by Yugoslavia. They claimed not only that the practicalities of self-management socialism were damaging to the economy but also that Yugoslavism itself was a drain on the economy. Any economic system imposed by Belgrade was necessarily alien to the Western European economic traditions of Croatia, they argued. Thus independence for Croatia would make Croats wealthier. Programmes of privatisation, currency reform and the introduction of a market economy would reunite Croats with their economic heritage. However, despite numerous economic reforms, including the much-vaunted stabilisation programme, most Croats became worse off. While the HDZ insisted that this was the result of the war, many people believed that it was the result of endemic corruption. That the HDZ chose to sell off state industries to its own members is unsurprising if we recall that the HDZ believed that it was at one with the Croatian nation. Viewed this way, only the HDZ could be the custodian of the economy. The HDZ insisted that allowing a free process of privatisation would threaten the economy by placing it at the mercy of foreigners or, worse, Croats who were less committed to the national project.

There were therefore at least two national narratives about the Croatian economy. On the one hand, the government and economic elite portrayed Croatia as a new Central European economy that had successfully seceded from Balkan self-management socialism. In the process of this disengagement, Croatia rediscovered the economic system that most closely fitted its economic culture and exposed the alien nature of the Yugoslav system. The new country was able to establish its own currency and achieve levels of inflation comparable with Western Europe. For some this was a source of great national pride. For others, however, talk of low inflation and foreign investment did not correspond with their view of a new economy characterized by 'crony capitalism'. For them, the new state meant unemployment and a fall in living standards. It meant that to survive they had to retain the habits learned during the communist period. Such habits, based on the belief that the state worked against the individual rather than for it, included trading on the black market and not declaring employment. The mood of trade unionists such as Davor Jurić was one of resigned disenchantment and pessimism about the future. For them, privatisation was a theft and the 'centuries of national dreaming' frequently referred to by Tuðman remained a dream. For in 1990s Croatia, as Slavenka Drakulić pointed out, 'no-one is getting rich by working,.$^{56}$ As the 1990s developed there was therefore widespread apathy towards the national rhetoric espoused by the HDZ and Franjo Tuðman.

\section{Football}

In the summer of 1999 Zagreb hosted the second World Military Games. According to the chief organiser, General Lučić, the games were significant because of the 'organisational achievements and [the] transmission of positive 
influences from Croatia to the entire world'. He also stressed that the games 'provided a new spirit to Croatian sports [and] its entire social life. ${ }^{57}$ The nexus of sport and nationalism is a growing area of interest to academics from several disciplines. ${ }^{58}$ In a 1990 conference on 'sporting nationalisms' three central themes were identified. These were: 'sport as a mechanism of national solidarity promoting a sense of identity, unity, status and esteem', 'sport as an instrument of confrontation between nations stimulating aggression, stereotyping and images of inferiority and superiority' and 'sport as a cultural bond linking nations across national boundaries, providing common enthusiasm, shared empathetic experiences, the transcendence of national allegiances, and opportunities for association, understanding and goodwill'. ${ }^{59}$ Mangen argued that, 'most contributors [to the conference on sport and nationalism] point to the significant contribution of sport in the making of modern European nations, both intentionally and unintentionally, internally as an agent of consolidation stressing similarity and externally as an agent of confrontation emphasizing difference' ${ }^{60}$

These tendencies were at work in Croatian football in the 1990s. The national team played a significant role in forging Croatian unity, promoting Croatia internationally and creating a popular homogenising sense of national pride that the disastrous economy or the Catholic Church failed to do. On the other hand, club football in Croatia promoted anti-government activism. Such movements included those defending the name of Dinamo Zagreb and the regionalist anti-Zagreb sentiments that were promoted by the Torcida fans of the Hajduk Split football club. Dinamo Zagreb acted as a catalyst for one of the best-supported anti-Tuðman lobbies in Croatia. This was a particularly interesting group because the 'Bad Blue Boys' (the self-designated name for Dinamo Zagreb supporters) were precisely the national constituency to which Tuðman first appealed in 1990. Furthermore, the Bad Blue Boys had eagerly volunteered to join the new Croatian Army (HV) at the start of the war.

When the Croatian national team achieved third place in the 1998 football World Cup in France, Franjo Tuðman opined that 'football victories shape a nation's identity as much as wars' ${ }^{61}$ One of the important products of Croatia's independence from Yugoslavia was thus its ability to field a national team in the first place. As the Croatian defender Igor Stimac declared on the eve of his appearance in the World Cup semi-final, 'we were under Yugoslavia for 45 years and we couldn't say we were Croats. Now we can. That is very important for us'. ${ }^{62}$ Moreover, the fact that the Croatian football team could beat teams from Western Europe gave the Croatian state equivalence with states such as Germany and the Netherlands. The significance of football for Croatian national identity was echoed by a close ally of Tuðman, Miroslav (Ciro) Blazević, the national team coach. Prior to a European Championships qualifying match against Milošević's Yugoslavia in Belgrade, Blazević told reporters, 'we should not hide it, this will be more than just sport ... every victory of the Croatian team is a victory for their people.$^{63}$ Blazević often made this link between the 'people' and the national football team. In an interview with Simon Kuper he argued 
that prior to each international match he invoked the memory of 'the people' for whom the players were playing. He told Kuper, '[o]n every occasion before a match I speak to the players of Croatia's problems, the suffering of all our patriots. Because in football motivation is very important. Yugoslavia, an unmotivated side, never won anything despite having some of the best players in Europe ${ }^{34}$

Blazević once commented that 'I have two gods. One is in heaven and the other one is Franjo Tuðman' ${ }^{65}$ The President exerted considerable influence over the national team. After the 1998 World Cup, the goalkeeper Dražen Ladić announced his retirement from international football and was reputedly telephoned by Tuðman and persuaded to continue playing for the national team. Similarly, it was widely believed that the frequent absence of Robert Prosinecki from the national team and his club team, Dinamo, owed more to his publicly stated views about politics and dislike for Blazević and Tuðman than to his football skills or injuries. Prior to a match against Estonia, Tuðman predicted that Croatia would win 6-1. With 15 minutes left to play the score was indeed 6-1 to Croatia and Blazević shouted to the Croatian captain, Zvonimir Boban, 'Stop! Do not score any more'. ${ }^{66}$

Much of the literature on sport and nationalism discussed the importance of national sporting heroes in promoting national unity. For Croatian football in the 1990s, two such heroes were Zvonimir Boban and Davor Šuker. Boban established his hero status in May 1990, just days after the Croatian elections that brought the HDZ to power, when he tackled a Serbian policeman who was beating a member of the Bad Blue Boys during a clash between Dinamo Zagreb and Crvena Zvezda Beograd (Red Star Belgrade). Davor Šuker became a national hero prior to being the top goal scorer in the 1998 World Cup. His oft-repeated pride at being able to play for Croatia endeared him to the national audience and his success as an overseas football player at Real Madrid served to 'glorify the Croatian state'. ${ }^{67}$

According to Slaven Lerotić, there was a 'cult of the state' in Croatia, which derived from the historical statehood narrative discussed in earlier chapters. ${ }^{68}$ Following this logic, the sporting successes of individuals like Davor Šuker did not reflect upon the sportsperson alone but also upon the Croatian state. This idea reflected the connection made between sporting success and national success alluded to by Blazević and helps to explain Tuðman's remarks about the importance of football in shaping national identity. Football players also helped galvanise national unity through their connections with the homeland. For example, Davor Šuker was born and brought up in the city of Osijek where his parents remained during the worst of the fighting in 1991. When asked about that period (he was in Spain during the war) Šuker replied that 'I think it was the most difficult period of my life. When you are playing football in a country that is peaceful ... you feel a bit guilty when you remember that there were a lot of people suffering back home. But I always hoped that my exploits would give a little joy to the fans who followed my career with keen interest. ${ }^{69}$ The CroatianAustralian football player, Mark Viduka, expressed a similar view. Viduka, 
whose uncle and grandfather were killed by the JNA on the same night in 1991, echoed Šuker by arguing that 'it's not nice to say it, but those players [Croats playing in foreign leagues] do more for Croatia than a soldier giving his life'. ${ }^{70}$

The 1998 football World Cup provided examples of the union between football players and the 'Croatian people'. According to one foreign observer, 'there is a relationship between player and follower that puts other countries to shame'. ${ }^{71}$ At the Croatian squad's French World Cup base in the village of Vittel it was reported that players and fans mingled in the bars and in some cases players paid for the fans' accommodation and tickets. Darko Tironi, a spokesman for the Croatian Football Federation (Hrvatska Nogomet Savez - HNS) explained that 'the players are very close to the fans', and BBC Television presenter Adrian Chiles, who has a Croatian mother, tried to explain this phenomenon by calling on viewers to 'imagine what it would be like if people here [UK] weren't allowed to call themselves English until seven years ago' ${ }^{72}$

The Croatian team had an inauspicious start to its World Cup campaign, narrowly beating the relatively weak Jamaican and Japanese teams and losing to one of the favourites, Argentina. In the second round, Croatia scraped past a Romanian side that had earlier defeated England, thanks to a retaken Davor Šuker penalty. It was only in the quarter-final match that the Croatian side caught the headlines and achieved a great 'national victory', by beating Germany 3-0.

The World Cup was not without its national controversies, however. The first controversy occurred at the press conference following Croatia's 1-0 victory over Japan. It transpired that the translator hired by FIFA (the world football federation) to translate for Ciro Blazević was a Serb. The Croats considered this highly insensitive at best, not only because of the recent history but also because the translator was expected to be able to translate the 'pure Croatian' language being used by the national coach, a task that a non-Croatian speaker would not be able to accomplish (see Chapter 6). ${ }^{73}$ The second incident occurred prior to the Croatia-Germany match. According to Branko Tuðen, while German television viewers were given the opportunity 'to see the atmosphere of the official box' and to see Chancellor Kohl during the playing of the German national anthem, such an opportunity did not extend to the Croats because the television director chose not to show Tuðman, even though he was sitting less that 10 metres away from Kohl. ${ }^{74}$ Writing in Večernji List, Tuðen argued that 'this approach is tasteless, not to mention insulting' and showed that the French 'underestimated the abilities of our players - hence, they underestimated the presence of our President, whose political moves cannot be forgiven by many, firstly pertaining to the toppling of the Versailles order' ${ }^{75}$ Here again we see a manifestation of Lerotićs notion of a cult of the state. The thrust of Tuðen's argument was that because Croatia should have been considered a serious competitor at the World Cup, President Tuðman should have been accorded a status identical to that of Chancellor Kohl.

Prior to the game against Germany, the Croatian defender Slaven Bilić offered a somewhat different reading of its significance. Asked whether the 
match would be a revenge for Croatia's defeat by Germany in the European Championships two years earlier, Bilić responded, 'I mean, what's revenge? There's no revenge. They didn't steal from us or kill someone. Football is only a sport, it's not like war ... Germany was the country that helped Croatia most in building up, politically and economically. ${ }^{76}$

Blazević described the match itself in Tuðman-like terms as a 'historic victory'. ${ }^{77}$ Croatia secured a 3-0 victory and passage to the semi-final. According to Marcus Tanner, 'Croats revelled in the attention their country received after reaching the semi-finals of the World Cup and welcomed the coverage which raised its profile abroad, finally convincing the world that Croatia was separated from Yugoslavia - seven years after independence' ${ }^{78}$ Following a narrow defeat by the eventual world champions France, Croatia beat the Netherlands to claim third place in the tournament. This performance was received with mass celebrations in Croatia. As Michael Walker wrote, 'coming second might suck to Tiger Woods or American advertising executives but to the footballers of a small, emerging country like Croatia, coming third in France in their first World Cup finals - has been the greatest statement in their young history'. ${ }^{79}$

There can be little doubting the importance of this success. Recognising this, leaders of all the major opposition parties attempted to claim the victory as their own. Even an American diplomat, Strobe Talbott, commented that 'Croatia's footballers have shown the world that Croatia is a small nation which can show its high level of competition and perseverance', adding that he believed that 'Croatia will do the same in the fields of economy, social services and democracy' ${ }^{80}$ An estimated 100,000 people greeted the team's return to Zagreb. ${ }^{81}$ Tuðman personally congratulated the players, telling them:

It is my honour, on behalf of the Croatian state leadership, to congratulate the players of the Croatian soccer representation for their great results at the World Cup. By reaching these heights, dear soccer players, you have contributed to Croatia which stood behind you in Zagreb. During your matches, the entire Croatian people, numbering some eight million, from the homeland and abroad stood behind you. You have given a great contribution in raising Croatia's reputation in the world. Your magnificent success is a great contribution to the independent state of Croatia. ${ }^{82}$

In this statement alone we can see many of the features of Franjoism and the role of sport in nationalism discussed earlier. First, the cult of the state is prominent in Tuðman's closing sentence. Moreover, earlier in the speech Tuðman indicated that he believed football to be a force for national unity, not only between Croats in Croatia, but among the 'eight million' Croats throughout the world. Not all commentators held such positive views about Croatia's footballing success. The London Evening Standard described Croatia as the 'most disgusting small nation in Europe' and writers in the Guardian took the rise to prominence of the Croatian flag as another opportunity to claim that both it, and the nation it represented, had fascist undertones. ${ }^{83}$ On the whole, however, 
international responses to the Croatian success were positive and within Croatia the success promoted the state and homogenised the Croatian people behind 'its' footballers. It was widely rumoured at the time that the government planned to capitalise on the success by holding early elections, though this did not materialise.

Although the World Cup success did much to promote national solidarity, it was a relatively short-lived phenomenon. Elsewhere, football provided a focus for discontent with the government, manifested in the battle over the name of the leading Zagreb team - Dinamo Zagreb or Croatia Zagreb. Football support had provided an important means of resistance in Yugoslav Croatia. Andrej Kricković, a Zagreb journalist, argued that the Bad Blue Boys (Dinamo Zagreb supporters) were at the forefront of the national movement 1990 and that they had offered their 'wholehearted support' to Franjo Tuðman and the HDZ in Croatia's first elections. ${ }^{84}$ This was particularly important at the time, Kricković argued, because Croatian national identity was confronting a massive propaganda assault that was launched by Milošević's Serbian regime. Referring to the Bad Blue Boys and the Torcida fans of Hajduk Split, Sasa Podgorelec (a Zagreb film director who produced a documentary on the Bad Blue Boys) argued that, 'they were conscious enough of their own identity and brave enough to express their wishes for Croatian independence ... when others were too frightened to say so'. ${ }^{85}$

In socialist Yugoslavia, football clubs were important channels for exercising political, social and economic influence. Typically, a club was linked to, and financially dependent on, a political group and was identified with that group's political views. This had an impact upon its football activities. Partisan Belgrade, for example, was known as the team of the JNA. As all Yugoslav footballers had to do national service they often ended up at Partisan and the better players frequently had their national service extended to prevent them returning to their original club. Crvena Zvezda (Red Star) was also attached to the JNA, but was more strongly linked to the Republic of Serbia and was seen as a club for Serbian nationalists. Hajduk Split was and is a focal point for Dalmatian regional identity - from Rijeka to Dubrovnik - but also had an interesting ambiguity at the heart of its identity. While being representative of Dalmatia (particularly in contemporary Croatia) and Croatian nationalism (in the early 1990s), Hajduk was originally a Partisan club supported by Tito because the city of Split was renowned as a JNA garrison city and had been a bastion of resistance to the fascists in the Second World War. All this ambiguity was captured in Hajduk. For the residents of Split, the meaning of Hajduk had a regional significance similar to that of Dinamo for Zagreb residents. On the other hand, for northern Croats and Slavonians, Hajduk prompted questions about the 'true-Croatianness' of the Dalmatians. ${ }^{86}$

Dinamo Zagreb was known as the team of the rulers of the Socialist Republic of Croatia and was widely seen as representing not only Croatian national identity in the Yugoslav leagues, but also Zagreb's particular identity within 
Croatia and Yugoslavia. Dinamo Zagreb also acted as a focal point of interest for the recently departed members of the Croatian diaspora. Diaspora groups formed clubs called Dinamo and referred to themselves as Bad Blue Boys. ${ }^{87}$ The infamous match against Crvena Zvezda came soon after the 1990 elections. On 13 May 1990 about 1,500 Crvena Zvezda supporters (Delije) arrived in Zagreb. Zeljko Raznatović, better known as the war criminal 'Arkan' whose Serbian Volunteer Guard ('Tigers') became renowned as one of the worst groups of militia responsible for many war crimes in the wars in Croatia and Bosnia and Hercegovina, was the leader of the Delije fan club. The Delije began destroying the south stands before the Bad Blue Boys tried to get across the pitch and the police responded in a heavy-handed and biased fashion. ${ }^{88}$ One of the most significant events of 13 May was the intervention of the future Croatian national team captain, Zvonimir Boban, mentioned earlier. This event achieved a mythical status as the first violence of the war. ${ }^{89}$

Once the war started, the Bad Blue Boys volunteered for the Croatian Army (HV) en masse. Before the army had its own badges, soldiers attached Dinamo badges to their military fatigues. ${ }^{90}$ Many were killed in the earliest fighting and the Bad Blue Boys erected a monument to their fallen friends outside the stadium at Maksimir. The epitaph read, 'to all Dinamo fans for whom the war started on 13 May 1990 and ended by them laying their lives on the altar of the Croatian homeland'. In 1994 Tuðman wrote that he was 'a Dinamo supporter like most Zagreb and Croatian ... patriots, because it was the most Croatian club in the Yugoslav federation'. ${ }^{91}$ Not many in Zagreb believed him, least of all because during his time as a major-general in the JNA in the 1960s he had been Chairman of Partisan Belgrade. ${ }^{92}$ Dinamo supporters claimed that not a single government or club official paid their respects at the monument.

Tuðman first changed the name of Dinamo Zagreb in 1991, arguing that it was a communist and Serbian name. The first name he chose was Hrvatski Akademski Sporski Klub Graðanski - 1903 Zagreb. This name consisted of two elements, which to anyone old enough to remember were the names of two rival pre-Second World War Zagreb clubs, HASK and Graðanski. Given that not many among the Bad Blue Boys recognised or remembered the ancient heritage of Croatian football, of which the new club name was supposed to remind them, Tuðman changed the name again in 1993 to Croatia Zagreb, although 'Croatia' is not even the Croatian word for Croatia (Hrvatska).

As Dinamo Zagreb had been the symbol of Croatian resistance to Yugoslavia and as the Bad Blue Boys had been the vanguard of active Croatian nationalism, the supporters were confused and disheartened by the decision to change its name. To them, the name change suggested that the change of regime had not equated to a change in political practices. Many Bad Blue Boys began to question why they had volunteered to fight and why so many had sacrificed their lives. While still attending matches at Maksimir, the Bad Blue Boys vented their anger at the VIP box, waving Dinamo flags and chanting 'Dinamo', in a clear sign of protest against the regime. At an election rally in 1995, Tuðman 
began berating the Dinamo fans, calling them foreign agents, to which his audience responded by chanting, 'Dinamo not Croatia'. Tuðman reacted by declaring, 'if you want Dinamo go to Serbia'. Unsurprisingly this did not endear him either to the people of Zagreb or to the war veterans whose 'Croatianness' he was questioning. ${ }^{93}$ Subsequently, the Bad Blue Boys decided to boycott home matches, watching Dinamo only when it played in European matches. Whereas the average attendance at Maksimir had been around 20,000 at the beginning of the 1990s, that figure fell to below 3,000 towards the end of the decade. ${ }^{94}$

The Bad Blue Boys took no pleasure from the success of Croatia Zagreb. Croatia was seen as the state team and they believed that the Croatian league was fixed to enable Croatia to win every year. ${ }^{95}$ The closing stages of the 1998-99 season seemed to confirm this belief. It was widely thought that the club NK Rijeka would win the championship as it led the league by a considerable margin. However, towards the end of the season a series of questionable refereeing decisions meant that NK Rijeka finished runners-up to Croatia Zagreb. Ivo Pukanić, editor of the weekly tabloid Nacional, obtained documents showing that referees had been pressurised by people close to the President to ensure Croatia Zagreb's triumph. Special police units attempted to recover the documents by raiding Pukanićs house and office. They failed and throughout July and August 1999 Nacional published one document every week showing how the ruling party helped to fix the results of football matches. ${ }^{96}$

Tuðman initially adopted a conciliatory response to Bad Blue Boys' agitation because this group had originally been part of his core constituency. In an open letter in 1994, he wrote:

Dear singing and always loyal 'Bad Blue Boys'. After the establishment of the free and independent, sovereign and democratic Croatian state, we embarked on decisive elimination of all those unhealthy things that the former Yugoslav and communist regime imposed on Croatian sports. Some petty politicians promote the demand to restore the name Dinamo because they are against the policy that under my leadership - brought into being the free and democratic, independent and internationally recognized Croatia. If we give in on this they would go further, and we will not allow the destabilisation of our independent Croatia. ${ }^{97}$

Needless to say, for people who believed themselves to be ardent Croatian patriots who had seen their friends killed on the battlefields, being told that they were being manipulated by 'petty politicians' who wanted to 'destabilise Croatia' did little to persuade them of the merits of the name change. One such 'petty politician', Zdravko Tomac - Deputy Prime-Minister in 1991-92 and presidential candidate in 1995 - had earlier noted that:

At that time [in the Yugoslav period] it was enough to be a Dinamo fan to be accused of nationalism. In 1972, after the Dinamo management had been purged of people with 'bad' political tastes [so-called nationalists] I became President of the Dinamo club and offered them a safe haven there. That is why I and many other people who have supported Dinamo through thick and thin find it insulting when 
we are accused of anti-Croatian stands and conservatism, only because we do not accept the change to the name of the club. ${ }^{98}$

What was worse, Tomac argued, was that the man responsible for the change in name and for the accusations was formerly chairman of Partisan Belgrade. Other typical accusations, aired after a violent demonstration in 1998, were that the Bad Blue Boys were agents of Yugoslav communists, and the international financier, George Soros, was paying them to destabilise Croatia. ${ }^{99}$

The struggle over the name of Zagreb's football team was also a struggle about the meaning of Zagreb's identity. In the previous chapter we saw that in 1995 the people of Zagreb had elected the opposition to power in the city assembly, a move that was blocked by the President. This prompted a fear among Zagreb's intellectual elite that the capital was being 'ruralised'. In particular, Kricković noted that there was a large influx of Hercegovinian Croats into Zagreb during the war. ${ }^{100}$ We noted earlier that the President praised the extreme nationalism of this group and held it up as an example to other Croats. A second influx of rural Croats were the Kosovar Croats, who set up home in a residential area near Dubrava (an eastern suburb of Zagreb), which became popularly known as Kosovarska. ${ }^{101}$ Therefore, the Dinamo campaign developed into a campaign to protect Zagreb's cosmopolitan identity against the perceived extremism of the rural Croats migrating to Zagreb. ${ }^{102}$

One of the less often cited legacies left to Croatia by Tito's Yugoslavia was institutionalised sport. In Tito's Yugoslavia, social elites gathered around football clubs. Tuðman's attitude towards football teams appears to have been very similar to Tito's. He tried to associate himself with the national football team. His close friend, 'Ciro' Blazević was appointed coach of the national team, despite his questionable past and his links with corruption at Marseille's football club. While the national team united the Croatian people around a common cause there was little evidence that the Croatia represented by the national team was a Franjoist Croatia, particularly as most of the national team did not play their club football in Croatia. However, throughout the World Cup in 1998 the government attempted to situate itself alongside the team, arguing that the national football team was successful because the Croatian state under the HDZ was successful. This reflected the 'cult of the state' identified by Slaven Lerotic and resonated strongly with the Franjoist understanding of the historical statehood narrative. This led Tuðman to conclude that the name Dinamo was an aberration because of its communist overtones. As a historian conscious of the historical statehood narrative, Tuðman thought that the name of the main Zagreb football team should be reverted to the 1945 name of two long-since defunct Zagreb clubs.

Changing Dinamo's name sparked fierce resistance from a section of Croatian society that had earlier been steadfast HDZ supporters. This resistance was heightened by Tuðman's response to the criticism, which was inspired by his own belief that an attack on him was an attack on Croatia. As so many of 
their number had been killed in the war, the Bad Blue Boys did not take kindly to being called 'Yugo-nostalgics'. Thus resistance in Zagreb both to the President and the renamed Croatia Zagreb increased exponentially to the extent that the capital became an opposition party stronghold whose inhabitants were strongly opposed to what they saw as the 'ruralising' tendencies of the HDZ. Therefore, prior to the 2000 elections the government ensured that Zagreb would be divided into four different electoral districts. Parts of Zagreb shared an electoral district with coastal areas. This move was designed to weaken Zagreb's political identity. Interestingly, the opposition won majorities in all four electoral districts.

Football was a hotly contested subject in Croatia. The Croatian national football team promoted national solidarity and unity, particularly during the 1998 World Cup. This was despite the overt control that the President exerted over the team. However, this national unity was short-lived. Against this backdrop, the Dinamo issue appears baffling at first. On the one hand it is startling that Tuðman could so successfully alienate one of his core constituencies. On the other hand, it seems bizarre that the nationalists in the Bad Blue Boys should worry about the name of their team at precisely the time when they were given the independent state for which they had agitated. On closer analysis, however, the Dinamo conflict posed fundamental questions about Croatian national identity. For the Bad Blue Boys in 1990, an independent Croatia ought to have meant an end to authoritarianism and foreign rule. It was for this that they went to war. However, by changing Dinamo's name, Tuðman demonstrated that the new regime would be just as authoritarian - and foreign - as the old regime. Even though many of the Bad Blue Boys were violent skinheads, they believed that Croatia ought to be liberal, democratic and European, a Croatia in which the right to support their own football club would be protected. However, by the mid-1990s they perceived that little had actually changed since the change of regime. Their flags were still confiscated, their songs remained banned and they were derided as foreign agents by the government, just as they had been by the communists. The Dinamo issue was representative of wider problems and helps to bring the competition over differing conceptions of Croatian national identity into focus. Furthermore, it exposes the failure of the government to impose its own interpretation upon the wider Croatian society at this third level of analysis.

\section{Istrian regionalism}

In 1990s Croatia, regionalism was a powerful source form of political opposition. However, this form of political mobilisation was relatively weak because of the centralised nature of the Croatian state and the concentration of political power and economic wealth in Zagreb. ${ }^{103}$ The Croatian flag includes the emblems of the so-called historic regions of Croatia. These are 'civil' Croatia, Slavonia, 
Istria, Dalmatia and Dubrovnik. The Croatian Triune Kingdom was known as the Kingdom of Dalmatia, Croatia and Slavonia. The Dalmatian region was first established during the Roman period and retained close links with Italy, thanks to long periods of occupation by the Venetians. ${ }^{104}$ The Croatian region with the longest history of independence, as a republic in its own right until the beginning of the nineteenth century, was Dubrovnik. However, in the 1990s the only region to successfully assert its political and regional identity was Istria. Istria is a peninsula at the northern end of Croatia's Adriatic coast. It is separated from the rest of Croatia by Mount Učka and is bounded on the other sides by Slovenia and the Adriatic Sea. It has a close proximity to Italy, both geographically and socially.

The existence of a strong and assertive Istrian regional identity was problematic for the elite in Zagreb. According to some lawyers, 'the Republic of Croatia is defined as a unitary and indivisible democratic and social state'. ${ }^{105}$ Such a system 'does not allow for any kind of complex state models such as federation of confederation'. ${ }^{106}$ In the early 1990s there was a wide-ranging public debate about the principles that should be used to determine the administrative borders of the new state. According to Mladen Klemenčić, a majority of geographers, spatial planners and political scientists favoured a system of between twelve and twenty counties based upon the old system of regional governance known as Županja. ${ }^{107}$ Davor Brunčić argued that this solution meant 'the return to the traditions of Croatian local state organization'. ${ }^{108}$ However, although 'historical inheritance' was taken into consideration when drawing Croatia's new internal boundaries, physical, demographic and economic indicators were also used and evidence taken from working papers written for decision makers suggests that the most important factor was the 'the existing network of central places'. ${ }^{109}$ Under this arrangement, only Istria and Dubrovnik retained territory analogues with their historical boundaries, while Dalmatia and Slavonia were divided into several counties. Minority rights were to be supported at the district and individual level rather than at county level because it was argued that no county had a distinctive ethnic composition deserving special rights. ${ }^{110}$

A great deal of work was put into insisting that Istria was Croatian and always had been. ${ }^{111}$ The core Franjoist argument was that despite the peninsula's many rulers (Venetians, Austrians and Italians) Istria has always been 'ethnically Croat'. ${ }^{112}$ For example, explaining why so many people in Istria called themselves 'Istrian' rather than 'Croat' in the 1991 census, Klemenčić, Vesna Kušar and Željka Richter concluded that the figures were distorted by the fact that Croatian Istria was formerly part of a wider political unit encompassing lands that were not part of Croatia. This, they argued, exacerbated regionalist tendencies. ${ }^{113}$ Similarly, Crljenko insisted that the dialects peculiar to Istria have Croatian origins and therefore pointed to the peninsula's Croatian heritage. ${ }^{114}$ Furthermore, according to a researcher based in the largest Istrian city, Pula, 'the most important topic of contemporary Istrian history is research of the 
emergence of the modern Croatian nation', which, the author concluded, 'represents a lasting and durable achievement of the Istrian Croats and Croats in general'. 115

What is particularly interesting is that these arguments were made in explicitly ethnic terms in contrast to the other nationalist claims that were framed by the historical statehood narrative. Because Istria was probably not part of the medieval kingdom, certainly never entered into a union with Hungary, spent most of its history under either Venetian or Austrian rule and usually both simultaneously (Venice ruled over most of the coastline, while the interior was mostly held by the Austrians), was not in the first Yugoslavia, and was only incorporated into Croatia after the Second World War, at which time only part of Istria was given to Croatia (a part of Istria is in the Republic of Slovenia), the historical statehood narrative is not a tenable basis for a Croatian claim to Istria. This posed a problem for a Zagreb government determined to oppose any manifestation of regionalism in Istria. Thus the government and many Croatian writers resorted to ethnic criteria to insist that Istria is Croatian. ${ }^{116}$ The selective application of criteria clearly presented problems. If, for instance, Istria was Croatian because it was mostly Croats that lived there for centuries, should not the Lika area of inland Dalmatia (so-called Krajina) be considered Serbian because mostly Serbs have lived there for centuries? Importantly, the historical statehood narrative was used to legitimise the state itself, not its particular boundaries. These ethnic arguments were deployed specifically against Istrian regionalists in order to cast doubt on to their claim to separateness rather than to justify the existence of the Croatian state per se. As we noted in Chapter 3, Croatian politicians, leaders and intellectuals have always disagreed on the precise extent and nature of the Croatian state.

At the beginning of the 1990s, journalist Mark Thompson visited Labin on Istria's southern coast. Labin contained the highest proportion of people (36 per cent) in the whole of former Yugoslavia who defined themselves as 'regionals' (in this case 'Istrians') in the 1991 census. ${ }^{117}$ According to Thompson, Istria was unique among former Yugoslav regions in having its territory defined with something approaching clarity because it is a peninsula bounded by mountains on one side and sea on the other. ${ }^{118}$ However, perhaps the most striking and commonly observed feature of Istrian identity was its heterogeneity. This may be a product of Istria's recent history, which is endowed with frequent population movements. Most recently, following Yugoslavia's annexation of Istria after the Second World War, tens of thousands of Italians were forced to leave and 'return' to Italy. They were replaced by Croats and Slovenes. This dramatic exodus followed a similarly large exodus of Croats and Slovenes from Istria prior to the Second World War when Mussolini's fascist Italy ruled Istria. ${ }^{119}$ For Fulvio Suran, a researcher in the Istrian town of Rovinj, Istrian identity is revealed in heterogeneity and pluriethnicity and can thus also be defined as pluri-identity'. ${ }^{20}$

The day-to-day reality of this multi-layered identity had salience beyond 
bilingual road signs and regionalist political activism. Many Istrians perceived national identity in purely instrumental terms. In 1994 three Istrian villages were annexed by Slovenia. When a Croatian reporter went to interview inhabitants of these villages he was confronted with a strange reaction. To this Croatian reporter the inhabitants declared themselves to be Croats. However, later in the day the reporter found that to Italian reporters the villagers had described themselves as Italians and to Slovene reporters they had called themselves Slovenes. Drakulić explained that the reporters were only allowing the villagers an 'either-or' choice in defining their identity, whereas for these villagers who inhabited a perpetual borderland between Croatia, Slovenia and Italy there was no incompatibility in being Croatian and Slovenian and Italian. ${ }^{121}$

The distinctive feature of Istrian identity in the 1990s was therefore its high degree of multinationalism, a feature of which Istrian politicians were very proud. ${ }^{122}$ This ambivalence towards national identity was reflected in attitudes towards the break-up of Yugoslavia. Sabrina Ramet, for example, argues that Istrians tended to feel uneasy about the dissolution because the multinationalism that was central to Istrian identity was better protected by confederal Yugoslavia than by a nationalist Croatia. ${ }^{123}$ This unease was expressed in a poll carried out by Mladina in 1990. The poll showed that 5.3 per cent of Istrians favoured an independent Istria, 22.2 per cent wanted to join Italy, 38.6 per cent preferred to join Slovenia, and only 18.4 per cent wanted the region to remain in Croatia on the condition that it was granted substantial autonomy. ${ }^{124}$ Later research, however, concluded that the 'vast majority' of Istrians favoured autonomy within a Croatian state. ${ }^{125}$

Istrian identity is an ambiguous multinational identity based on an attachment to the peninsula's territory. Such ambiguity was clearly an anathema to the Franjoist elite in Zagreb. While many in Zagreb saw Istrian identity as a challenge to Croatian national identity, this zero-sum calculation was not prevalent in Istria itself. Vjeran Katunarić explains that 'a majority of Istrians do not see their regional identity in exclusive terms: "Istrianness" and "Croatness" are not held to be mutually exclusive. ${ }^{126}$ There was much less social distance between Istrians and members of other national communities than was the case in the rest of Croatia. The space between Istrian Croats and Italians was virtually non-existent, while the space between Istrian Croats and Serbs was much less pronounced than in other parts of Croatia. ${ }^{127}$

One of the most interesting problems was the question of how the peninsula developed such a strong regional identity and a politically resonant regionalism while other regions did not. The separation of Dalmatia and Slavonia into different counties inhibited the growth of regionalist parties there. The region with the strongest tradition of independence and autonomy was Dubrovnik, yet although Dubrovnik was given its own county the inhabitants did not establish a strong regionalist movement. There are seven explanations as to why Istria developed its own identity and politics in the 1990s while other regions did not. These are: a distinctive history, an equally distinctive geography, the economy, 
the proximity of the 'West' and the importance of 'Western' ideas, the significance of the Italian community, the activism of the IDS, and the effect of the recent war.

The distinctiveness of Istrian history was the first thing that many Istrians pointed to when asked why their region should be granted autonomy. ${ }^{128}$ There was considerable debate between Croatian and Italian historians about the origins and fate of the Histre tribes who were the first known settlers on the peninsula prior to the Roman conquest. According to some writers, the Histre pre-dated the arrival of Slavs on the Adriatic coast. ${ }^{129}$ Istrians go on to point to their close incorporation in the Roman Empire - evidenced today by the amphitheatre at Pula - and their long association with Venice and Vienna. Nenad Klapčić argued that Western European political ideas were prevalent in Istria because of this association and that this explained why 'Istrian values' were at one with the values of the present day European Union. ${ }^{130}$ The fortified border between the Venetian Republic and the Habsburg Monarchy was located in Istria, bringing many different nationalities to the peninsula and fostering the multinationalism that is a cornerstone of contemporary Istrian identity. In more recent times, Istrians point out that neither fascism nor communism were strongly supported during the Second World War and that instead most Istrians took a 'pragmatic view' of their relations with the Italian fascists, the Ustaša and the Partisans, who each controlled the peninsula at some point. ${ }^{131}$ Thus the first claim made by Istrians was the separateness of their history. However, other regions of Croatia had a similarly separate history. Dubrovnik, for instance, was an independent republic for around five centuries.

The second argument was that unlike most other regions in former Yugoslavia, Istria is geographically well defined. Moreover, it is not well connected to the rest of Croatia. The region has a longer border with Slovenia than it does with Croatia and travel from Croatia into Istria is only possible through a tunnel under Mount Učka. As Mark Thompson observed, 'nobody passes through Istria; one goes into it. It has always been a region in the fullest sense, with its own history, dialects and folklore'. ${ }^{132}$ According to a tourist road map, the region is geographically unique and its entire history and identity has been shaped by that geography. ${ }^{133}$ While no other Croatian region has such geographic homogeneity, it should also be remembered that the northern part of the peninsula is in Slovenia and, as Drakulić noted earlier, this borderland is far from well defined.

The third argument was that Istria had a distinct political economy. One of the main goals of the IDS was to obtain a level of regional economic control similar to that enjoyed by Istria in Tito's Yugoslavia. According to Nenad Klapčić, under Yugoslav rule Istria had controlled 60 per cent of its finances itself. He estimated that by the end of the 1990s about 10 per cent of public finance was controlled by the region. Furthermore, Klapčić believed that the Zagreb elite had attempted to undermine the Istrian economy, parts of which had a GNP per capita 50 per cent higher than the Croatian average. ${ }^{134} \mathrm{He}$ argued 
that the government frequently criticised Istrians because of their attempts to establish close economic ties with Italy and Slovenia. Conversely, the government sold Istrian resources to foreign companies for considerably less than they were worth in order to discredit and weaken the indigenous economy. One example of this was the sale of Istrian Gas to the Italian firm, Agip, which Klapčić claimed cost Istria millions of dollars in lost potential earnings. ${ }^{135}$ Therefore, Istria can be understood as a distinctive economic region because it is considerably wealthier than the rest of Croatia. The region is divided into several districts and throughout the 1990s none of them had a GDP per capita lower than the Croatian average, while in coastal areas it was considerably higher. Furthermore, the Istrian economy was distinct because of its type. Based on tourism, it had a level of services comparable with that of Western European states and attracted large amounts of foreign currency. ${ }^{136}$ Towards the end of the 1990s, tourism began to regain the levels enjoyed in the 1980s, while other tourist areas such as Makarska (south of Split) and Dubrovnik had not recovered nearly as well.

The fourth argument was that Istria enjoyed a geographic and social proximity to Western Europe that influenced the predominant 'world view' of Istrian identity. According to the IDS, Istria was a region where people supported the ideas of democracy and freedom of speech to a far greater extent than in the rest of Croatia. It argued that because of Istria's geographical proximity to Italy and the shared history of the two, Western ideas were more widely articulated in Istria than elsewhere. One example of this was the proEuropean stance of the IDS, which was not wholeheartedly shared by other political parties, who were more eager to protect Croatia's hard-earned sovereignty than sacrifice it to Brussels. Istria became a member of the Association of European Regions and moved to its forefront by hosting its annual summer school in 1999. Istria became a bastion of the idea of a 'Europe of the regions' because, as Drakulić pointed out, 'the Istrians of today ... have learned to put their region above nation or ideology'. ${ }^{137}$ This 'European world view' was also present in public opinion and social attitudes. Attitudes towards sexuality and marriage among educated Istrians were considerably more liberal than those in other areas of Croatia, with the exception of Zagreb. ${ }^{138}$ It was claimed that because of its attitudinal and geographic proximity to Italy, Istria was in a position to become more closely integrated into the European matrix of regions. Not only did the IDS support rapid entry into the EU, it also envisaged a 'Croatia of the regions' whereby counties would be amalgamated into larger regions and power devolved from Zagreb to centres such as Pula (Istria), Split (Dalmatia) and Osijek (Slavonia). ${ }^{139}$ However, while this was certainly a feature of Istrian identity it was by no means the only Croatian region to boast a 'European world view'. Both Dubrovnik and coastal Dalmatia (particularly the city of Zadar) had similar foreign connections and the small northern region of Meðimurije had very close links with neighbouring Hungary and a large Hungarian minority in the region. It was only through the political activism of 
the IDS that Istria became incorporated into the matrix of European regions. Indeed, attitudinal surveys suggested that the 'Western' views held in Istria were held to the same extent in Zagreb as well.

The argument that Istrian identity had a 'European world view' went hand in hand with the view that Istria was a special region because of its Italian minority. The most active minorities in taking up the considerable rights bestowed upon them by the constitution were the Hungarian and Italian communities. There were principally two reasons for this. On the one hand, both minorities had the active support of their nation-name-bearing states. On the other hand, the Croatian government was keen to foster good relations with these minorities because of their links with mainstream European states and because members of these minorities were perceived to be more 'loyal' than other minorities. The relative number of volunteers for the Croatian Army (HV) was not noticeably different in Istria than in other regions not directly affected by the war. The siege of the JNA barracks in Pula by local defence forces was one of the most effectively organised and well-supported siege operations of the war. ${ }^{140}$ The Italian community developed an extended network known as the 'Italian Union', which organised cultural events and promoted Italian folklore in Istria. ${ }^{141}$ This was also used to promote the Italian dialect of Croatian known as Čakavica, which is peculiar to Istria. The newspaper Novi List, which is produced in Rijeka (very near to Istria), frequently used this dialect and, although not as radical as the Feral Tribune, often voiced its concerns about Istrian regional issues. ${ }^{142}$ These cultural networks enabled the promotion of Istrian culture and folklore, with the Italian community as the politically active driving force.

The sixth argument was that Istria became a uniquely distinct region in the 1990s because of the political success of the IDS. At the end of the 1990s the IDS held about 70 per cent of seats in the county assembly and had acquired over half the Istrian vote in national elections. The IDS rapidly became a genuinely regional party, winning majorities of votes from all the national communities of Istria as well as from those who described themselves as 'Istrian'. The core principles of the IDS programme were outlined in the 'Rovinj declarations' of 1991 and 1994. They contained advocacy of individual human rights but also insisted that 'the differences and distinctions of the various parts of Croatia as manifested and verified by its regions be considered as the wealth of Croatia' and that 'a more democratic system of 6-8 regions (which would hold a notable portion of legal capabilities) be established to replace the current system', and finally that 'regions be allowed to have their own legislation which would guarantee rapid and commendable development'. ${ }^{143}$ As well as being electorally successful, the IDS was also successful in putting the issue of regionalism on to the political agenda. According to one analyst, despite its small size and the often outright opposition of other parties to the very idea, regionalism was one of the most frequently discussed topics in election campaigns. ${ }^{144}$ The success of the IDS was in stark contrast to the fortunes of the other main regionalist party, 
Dalmatian Action, which lost its only Sabor seat in the 1995 elections. ${ }^{145}$ The political activism of the IDS was crucial in publicising Istria's unique identity and challenging the vision of Croatian identity articulated by the HDZ (see Chapter 4).

The final explanation as to why Istria was able to establish its particular identity within the Croatian polity goes further towards explaining why other regions did not. According to Ivan Rimac, proximity to the war assisted the ruling party's quest for a homogenous Croatian nation. Those regions most exposed to the ravages of war, such as Slavonia, Lika, parts of Dalmatia (particularly Zadar) and Dubrovnik, did not develop political identities that deviated from the Franjoist view of 'Croatness'. These regions also tended to support the HDZ, though by 1999 this tendency had almost entirely evaporated. They supported the HDZ because its programme focused solely on the protection of Croatian sovereignty and territorial integrity. To those who had first-hand experience of the violence that accompanied that threat to sovereignty, this issue overwhelmed all others. Because Dubrovnik and its surrounding area was the target of a sustained assault in 1991 (which continued sporadically until 1995) and because the integrity of the city and the lives of its inhabitants were constantly and genuinely threatened, the majority of people in Dubrovnik perceived that their physical security depended upon a defence mobilised by Croatia as a whole. As such, the HDZ became popular and regionalist ideas were considered to be dangerous and fractious notions that Dubrovnik could ill afford. ${ }^{146}$ Other than the crisis at the JNA barracks in Pula in 1991, Istria was not directly affected by the war. To keep the tourist industry operating as much as possible, refugees from other parts of Croatia and Bosnia and Hercegovina were mostly housed on the Dalmatian coast where the tourist industry had been decimated by the war; they were kept away from areas where the tourist industry was still functioning - such as Istria. Because of this distance from violence, Istria escaped the homogenising effect of the war that made multinationalism more problematic. Hence, Istria was able to retain its multinational identity and specific regional identity to a greater extent than other regions. ${ }^{147}$

For the proponents of Franjoism, Istrian regionalism represented a challenge to 'true' Croatian identity rather than a positive exercise in Westernstyle pluralism. Vesna Pusić, a sociologist and leading member of the HNS, argued that the government constructed 'internal enemies' to legitimise repressive measures. According to the government, she argued, the internal enemy wanted to bring down the state. Given that the state was democratic, this meant that the internal enemy wanted to bring down democracy itself. ${ }^{148}$ Therefore, 'the conclusion is that we must suspend democracy in order to prevent the internal enemy from destroying it'. ${ }^{149}$ One group of internal enemies was the Bad Blue Boys discussed earlier and another were the Istrians who were branded as enemies.

Tuðman spearheaded the attack on the Istrians. He insisted that 'some bought an idea that the people, the nation, are not so important as the region. 
That idea is directed against Croatian independence and sovereignty'. ${ }^{150}$ For Tuðman, regionalist tendencies in Istria were best described as 'irredentism' organised by 'disintegrative elements' ${ }^{151}$ Such elements were organised by the Italian community in Istria, enabling Tuðman to tell 'his' people that 'we are facing the continuous presence of Italian imperialism and irredentism'. ${ }^{152}$ These imperialists engaged in violent acts against the Croatian state. He claimed that 'some Italian generals advised Serbs how to conquer Zadar'. ${ }^{153}$ Tuðman also railed against the cultural autonomy and language rights of the Italian community that were guaranteed by the Croatian constitution. For him, a policy of bilingualism in Istria constituted a direct threat to Croatian sovereignty. ${ }^{154}$ It is interesting to note, however, that in his vilification of Italian imperialism Tuðman ignored the fact that by the mid-1990s a majority of Croats in Istria also supported the IDS.

Tuðman was not alone among Croatian politicians in condemning manifestations of Istrian regionalism. Responding to the IDS' 'declaration of the multiethnic and multilingual Istria county', which described both Italians and Croats as 'national communities', Dražen Budiša (leader of the HSLS) condemned what he saw as the attempt to transfer the special rights enjoyed by the Italians prior to the Second World War on to the contemporary Croatian statute. In a speech in the Sabor, Budiša complained that the Italian community was deliberately trying to increase its numbers in Istria at the expense of Croats in the region. Budiša highlighted Article 4 of the 'Rovinj Declaration' that announced a determination to 'promote and encourage minority languages and cultures in its territory in order to preserve the identity of a unique and unified Istrian culture'. He claimed that the promotion of this culture would negate Croatian culture in Istria. Therefore, he argued, the IDS declaration represented an assault on Istrian Croats. ${ }^{155}$

Opposition to Istrian regionalism manifested itself in practical policy. In the 1990 elections, HDZ candidates were defeated throughout the region and the adjoining Kvarner region (Rijeka). In retaliation, the new government used its control of ministries to shut down alternative sources of information in the region. In one early instance in August 1990, the Ministry of Information dismissed the director of the radio and television station at Pula and suspended the station's operating license. ${ }^{156}$ In other instances, agents close to the HDZ attempted to ensure that if they were to be denied political power in Istria they should at least secure economic power in the region. Thus the party faithful replaced enterprise managers throughout the region and the privatisation programme was manipulated to ensure that enterprises were not sold to employees and thus remained in the hands of the privatisation funds (CDNS), in other words the state and the HDZ. This tactic was used most frequently in the regulation of the media in Istria, although the most popular newspaper, Novi List, was able to maintain a relatively high degree of editorial independence. ${ }^{157}$

Another way that the government sought to disrupt the strength of the Istrian movement was by locating the regional administrative centre in the 
relatively remote town of Pazin. Rather than situating the administrative centre in the region's largest city and central focal point, Pula, the government decided that local government should be based in Pazin, which is located in central Istria. Because Istria's large settlements are mostly on the coast, Pazin is a rather remote town surrounded by farmland and small villages and is poorly connected to the rest of Istria. The semi-official view was that it would stimulate the local agricultural economy, which was not as developed and received far fewer tourists than the rest of the region. Moreover, according to Mladen Klemenčić, Pula is a 'marginally located' town while Pazin is more centrally located. ${ }^{158}$ However, although Pazin does have railway connections with Zagreb, the travelling time by road from Zagreb to Pula and Pazin is not very different. Furthermore, Pula is connected to the other major Istrian centres (Umag, Poreč, Rovinj and also Rijeka) by relatively fast new 'highways' and has its own international airport. Add to this the fact the Pula is the largest city in Istria, has the largest port in Istria, and houses most offices of governmental institutions and non-governmental organisations, it becomes clear that Klemenčićs instrumental arguments need to be brought into question.

Other writers, and the IDS itself, believed that political rather than instrumental motives were at the fore in the decision to locate the administrative centre in Pazin. Ivan Rimac pointed out that the ethnic composition of Istria is such that interior areas contain larger majorities of people describing themselves as 'Croats' than coastal areas. The largest majority of Croats is to be found in the town of Pazin. Thus, the argument goes, the location of the centre was prompted by a desire on the part of the HDZ for local bureaucracies to be controlled by 'Croats'. Furthermore, because Pazin is isolated from the coastal towns this location created a distance between local government and the coastal areas, which are more heavily populated by Italians and IDS supporters. ${ }^{159}$ Finally, Pazin was historically the centre of Croatian resistance and political organisation in Istria, so it is thought that the historian president valued the history of Pazin more than the history of the more Romanised and Italianised Pula. Moreover, locating the administrative centre in Pazin pointed to a degree of historical continuity in Croatian statehood and political activism in Istria.

The Istrians articulated the most coherent counter-narrative to Franjoism in the 1990s. They made seven key arguments to emphasise their distinct regional identity. The first Istrian claim, that the peninsula had a distinct history, constituted a direct attack on the historical statehood narrative. Simply put, it was claimed that Istria did not figure in the historical narrative outlined earlier. The six other arguments included the geographical separateness of the peninsula, its distinct political economy, its proximity to Western Europe, its European 'world view', and the successful political mobilisation driven by the Italian community. These factors, Istrians argued, produced a heterogeneous society in which national identities were intermingled and subsumed in regional identity. Many Istrians saw no incompatibility between being Croatian and Slovenian and Italian all at once. This heterogeneous view was clearly at odds 
with the vision of national identity articulated by the HDZ. In response, throughout the 1990s the government attempted to undermine Istrian identity by a combination of subtle administrative manoeuvres and open attacks that questioned whether the Istrians were loyal citizens.

Istrian regional identity posed a serious threat to Tuðman's view of a homogenous Croatian national identity. Not only was 'Istrianness' a multinational and multicultural identity that was tied to a region rather than the nation, its ambivalence towards the national question was clearly a threat to Franjoism. The Istrians were also particularly irritating because they could point to a separate history, one in which Istrians as referents were much maligned by Italians, Yugoslavs and Croatian centralisers. Rather than seeing Istrian identity as a model of Europeanisation to be adopted throughout Croatia, the government saw it as a challenge and attempted to control it by branding the Istrians as 'internal enemies' of the state and behaving accordingly. This had the predictable effect of hardening the Istrian stance and increasing support for the IDS and other opposition parties in Istria.

\section{Notes}

1 M. Veselica, 'The Croatian democratic movement 1966-71', in B. Katich (ed.), So Speak Croatian Dissidents (Toronto: Ziral, 1983), p. 94.

2 Veselica, 'The Croatian democratic movement', p. 98.

3 Katich, So Speak Croatian Dissidents, throughout. For details on the economic aspects of the break up of Yugoslavia, see I. Bičanić and M. Škreb, 'The Yugoslav economy from amalgamation to disintegration: failed attempts at moulding a new economic space 1969-1993', in D. Good (ed.), Economic Transformation in Central and Eastern Europe (London: Routledge, 1994).

4 Ž. Rohatinski, 'Ekonomske situacija na pocetku 1993 godine', in Z. Rohatinski and D. Vojnić (eds), Aktualni Problemi Privrednih Kretanja i Ekonomske Politike Hrvatske (Zagreb: Ekonomski Institut, 1993), p. 3. Also see S. Mateša and F. Brekalo, The Country Privatization Report - 1992: Croatia (Zagreb: Agency for Restructuring and Development, 1992), p. 7.

5 Simply put, this meant that Zagreb printed money, it came into the possession of Serbs in Croatia who transferred it to Belgrade and was then often spent on arming the Serbian militias operating in Croatia. Two oversights allowed this to happen. First, Croatia and Serbia still had the same currency, and second it was still legal to transfer that money from Croatian accounts into Serbian accounts. See B. Schonfelder, 'Croatia: between reform and post-communist populism', Communist Economies and Economic Transformation, 5:3 (1993), p. 319.

6 E. Kraft and W. J. George, The Structure of the Banking System in Croatia (Zagreb: Hrvatske Narodna Banka Survey No. 3, 1993), p. 1.

7 D. Vojnić, 'Economy and politics of transition: the road to the welfare state and economy', Croatian Economic Survey (Zagreb: Ekonomski Institut and Hrvatske Narodna Banka, 1995), p. 249.

8 Vojnić, 'Economy and politics', p. 252.

9 Ministry of Development and Reconstruction, Handbook of the Ministry of Development and Reconstruction (Zagreb: Ministry of Development and Reconstruction, 1997), p. 1. 
10 P. Jurković and M. Škreb, 'Financial Reforms in Croatia', Hrvatske Narodna Banka Working Papers 1:1 (Zagreb: Hrvatske Narodna Banka, 1994), p. 8.

11 See Z. Anušić, Ž. Rohatinski and V. Šonje (eds), A Road to Low Inflation (Zagreb: Vlada Co., 1995) and M. I. Bleyer and M. Škreb (eds), Macroeconomic Stabilization in Transition Economies (Cambridge: Cambridge University Press, 1997).

12 See, for example, Croatian Investment Promotion Agency (CIPA), Croatia: Economic Outlook 1999 (Zagreb: CIPA, 1999).

13 European Bank of Reconstruction and Development (EBRD), 'Investment climate', in A. Jolly and N. Kettaneh (eds), Doing Business in Croatia (London: Confederation of British Industry, 1998), p. 7.

14 See, 'Corporate news', Government of the Republic of Croatia Newsletter, January 1999, p. 5.

15 Author's interview with Branko Gračanin, Chamber of Economy, Zagreb, 8 July 1999.

16 'Corporate news', p. 10.

17 See Kraft and George, The Structure of the Banking System, pp. 7-8.

18 CIPA, Croatia: Economic Outlook 1999, p. 48.

19 M. Škreb, 'Economic transition in Croatia: an insiders view', Journal of Democracy, 17:2 (1998), 76.

20 For a summary of the banking system in Yugoslav Croatia see International Monetary Fund (IMF), Croatia - Selected Issues and Statistical Appendix (Washington DC: IMF Report No. 97/35, 1997), p. 41.

21 Kraft and George, The Structure of the Banking System, p. 12.

22 Kraft and George, The Structure of the Banking System, p. 12.

23 Hrvatske Narodna Banka (HNB), Banks at the Crossroads: A Report on the Banking System in the Republic of Croatia (Zagreb: HNB Survey No. 4, 1997), p. II.

24 I. Bičanić, 'Privatization in Croatia', East European Politics and Societies, 7:3 (1993), p. 435.

25 Author's interview with Branko Gračanin. Also, author's interview with Davor Jurić, President of the Independent Federation of Croatian Trades Unions, 31 August 1999.

26 Schonfelder, 'Croatia between reform', p. 321.

27 Večernji List, 20 June 1999.

28 Bičanić, 'Privatization in Croatia', p. 423.

29 Bičanić, 'Privatization in Croatia', p. 424.

30 C. Mckenna and P. R. Miličić, 'Privatization', in Jolly and Kettaneh (eds), Doing Business in Croatia, p. 29.

31 Newsletter of the Government of the Republic of Croatia, May 1999, p. 1.

32 Croatian Chamber of Economy, Croatia Outlook, 2:9/10 (1996), 3.

33 Author's interview with Zlatko Popić, senior member of the Liberal Party secretariat and organiser of the parties 'meet the press' initiative in which Vlado Gotovac disseminated his views on contemporary Croatia. Zagreb, 18 July 1999.

34 These are recorded in the records of the Sabor. See Privredni Vjesnik No. 2770 (7 December 1992) and No. 2780 (22 February 1993), p. 3.

35 Author's interview with Zdenko Franić, SDP executive committee member, Zagreb, 7 July 1999.

36 D. Feletar and Z. Stiperski, 'The development and structure of the Croatian economy', Geojournal, 38 (1996), 442.

37 Croatian Chamber of Economy, Croatia Outlook, 2:2/3 (1999), p. 1.

38 CIPA, Croatia: Economic Outlook 1999, p. 11.

39 CIPA, Croatia: Economic Outlook 1999, p. 11.

40 CIPA, Croatia: Economic Outlook 1999, p. 66. In 1998 most Croatian exports went to Italy (17.7\%), Germany (16.9\%), Bosnia and Hercegovina (14.4\%), Slovenia (9.5\%) and Austria (5.4\%). Most imports came from Germany (19.3\%), Italy (17.9\%), Slovenia (8.6\%), Austria (7.3\%) and France (4.8\%). Figures from Croatian Chamber of 
Economy, 'Foreign trade and the customs regime', in Croatia: Your Business Partner (Zagreb: Croatian Chamber of Economy, 1999).

41 CIPA, Croatia: Economic Outlook 1999, p. 67.

42 Croatian Chamber of Economy, Croatia Your Business Partner, p. 45.

43 Croatian Chamber of Economy, Croatia Your Business Partner, p. 45.

44 Škreb, 'Economic transition in Croatia', 77.

45 Republic of Croatia Central Bureau of Statistics, Statistical Information 1998 (Zagreb: Central Bureau of Statistics, 1999), p. 21. Figures on wages are from Hrvatske Narodna Banka (HNB), Annual Report 1998 (Zagreb: HNB, 1999), p. 50.

46 Republic of Croatia Central Bureau of Statistics, Statistical Information 1998 (Zagreb: Central Bureau of Statistics, 1999), p. 127.

47 Ž. Rohatinski, 'New challenges', in Croatian Economic Survey 1995 (Zagreb: Ekonomski Institut and Hrvatkske Narodna Banka, 1996), p. 5.

48 Kraft and George, The Structure of the Banking System, p. 3.

49 See Newsletter of the Government of the Republic of Croatia, December 1998, p. 5.

50 See a special edition on the unofficial economy in Croatia in the journal Financijska Praksa, 21:1-2 (1997).

51 'How many jobless in Croatia?', Croatia Weekly, 74, 1 July 1999.

52 Škreb, 'Economic transition in Croatia', 78.

53 Škreb, 'Economic transition in Croatia', 78.

54 Croatian Chamber of Economy, Croatia Outlook, 2:7-8 (1999), 1.

55 Croatian Chamber of Economy, Croatia Outlook, 2:7-8 (1999), 1.

56 Slavenka Drakulić, Café Europa: Life After Communism (London: Abacus, 1996), p. 66.

57 'Military games open many doors for Croatia', Croatia Weekly, 79, 20 August 1999.

58 See, for example, M. Polley, Moving the Goalposts: A History of Sport and Society Since 1945 (London: Routledge, 1945); L. Allison (ed.), The Politics of Sport (Manchester: Manchester University Press, 1986); R. Holt, J. A. Mangen and P. Lanfranch (eds), European Heroes: Myth, Identity, Sport (London: Frank Cass, 1996); J-M. Brohm, Sport: A Prison of Measured Time, trans. I. Fraser (London: Ink Links, 1978); A. Guttmann, Sports Spectators (New York: Columbia University Press, 1986); J. Riordan, Sport in Soviet Society (Cambridge: Cambridge University Press, 1977); J. Bale, Sport, Space and the City (London: Routledge, 1993); F. Inglis, The Name of the Game: Sport and Society (London: Heinemann, 1977); and R. Giulianotti and J. Williams (eds), Game Without Frontiers: Football, Identity and Modernity (Aldershot: Ashgate Publishing, 1994).

59 J. A. Mangen, 'Introduction', in J. A. Mangen (ed.), Tribal Identities: Nationalism, Europe, Sport (London: Frank Cass, 1996), p. 1.

60 Mangen, 'Introduction', p. 8.

61 A. Kricković, 'Football is war', Transitions, 6:3 (1999), 47.

62 Independent, 8 July 1998.

63 BBC, 'More than a football match', 17 August 1999 (www.bbc.co.uk/news/crowrldcup/ ghdu76). Emphasis added.

64 S. Kuper, Football Against the Enemy (London: Phoenix, 1996), p. 233.

65 Kricković, 'Football is war', 47.

66 Kuper, Football Against the Enemy, pp. 233-4.

67 R. Hay, 'Croatia: community, conflict and culture: the role of soccer clubs in migrant identity', in M. Cronin and D. Mayall (eds), Sporting Nationalisms: Identity, Ethnicity, Immigration and Assimilation (London: Frank Cass, 1998), p. 49.

68 Author's interview with Slaven Lerotić, Professor of Political Science and Government Advisor on international affairs. Zagreb, 10 September 1999.

69 www.kmg.tartu.ee/-karh/interview.htm (accessed 27 May 1999).

70 Kuper, Football Against the Enemy, p. 232.

71 Independent, 8 July 1998. 
72 Independent, 8 July 1998.

73 This incident was widely reported in Croatia on 21-22 June, both in the daily newspapers Večernji List and Vjesnik and on Croatian television (HRTV).

74 Večernji List, 7 July 1998.

75 Večernji List, 7 July 1998.

76 Guardian, 11 July 1998.

77 Independent, 6 July 1998.

78 Independent, 10 July 1998.

79 Guardian, 13 July 1998.

80 Croatian Information Centre (Zagreb), 7 July 1998.

81 Croatian Information Centre (Zagreb), 13 July 1998.

82 Jutarnji List, 13 July 1998. Emphasis added.

83 Guardian, 8 July 1998.

84 Kricković, 'Football is war', 46.

85 Kricković, 'Football is war', 46.

86 Kricković, 'Football is War', 47.

87 J. Hughson, 'Football, folk dancing and fascism: diversity and difference in multicultural Australia', Australian and New Zealand Journal of Sociology, 33:2 (1997), 167-85.

88 Kricković, 'Football is war', 47.

89 Kuper, Football Against the Enemy, p. 228.

90 Kricković, 'Football is war', 47.

91 Kricković, 'Football is war', 47.

92 Kricković, 'Football is war', 47.

93 Kuper, Football Against the Enemy, p. 231.

94 This figure is given in an official NK Croatia publication: NK Croatia and the Champions League (Zagreb: NK Croatia, 1998), p. 13.

95 Author's interview with Sasa Djačanin, Zagreb, 6 July 1999.

96 See S. Malović and G. W. Selnow, The People, Press and Politics of Croatia (Westport: Praeger, 2001).

97 Kricković, 'Football is war', 48.

98 Z. Tomac, The Struggle for the Croatian State (Zagreb: Profikon, 1993), p. 50.

99 Kricković, 'Football is war', 49.

100 Kricković, 'Football is war', 48.

101 Author's interview with Ognjen Čaldarović, Professor of Sociology, University of Zagreb, 16 September 1999.

102 Vladimir Bedenko has traced the development of a particular - cosmopolitan - popular identity in Zagreb back to the Middle Ages. Though such a genealogy is problematic, Bedenko's work helps to expose the widespread belief that Zagreb does have its own identity, and provides a historical foundation for such an identity. See V. Bedenko, Zagrebački Gradec: Kuća i Grad u Srednjem Vijeku (Zagreb: Školska Knjižara, 1996).

103 Author's interview with Ivan Rimac, Institut Društvenoh Znanosti 'Ivo Pilar' (Ivo Pilar Institute of Social Science), Zagreb, 6 September 1999.

104 See M. Klemenčić (ed.), A Concise Atlas of the Republic of Croatia and the Republic of Bosnia-Hercegovina (Zagreb: Miroslav Krleža Lexicographic Institute, 1993), p. 45. On Dalmatian identity and history see F. Violich, The Bridge to Dalmatia: A Search for the Meaning of Place (Baltimore: John Hopkins University Press, 1997).

105 Z. Lučić, 'On the constitutional organization of the Republic of Croatia', in D. Brunčić, Z. Lučić, V. Ljubanović and I. Vrjkić (eds), Legal System of the Republic of Croatia (Osijek: Collegium, University of Osijek, 1998), p. 15.

106 Lučić, 'On the constitutional organization', p. 16.

107 M. Klemenčić, 'Administrative-territorial division of Croatia', GeoJournal, 35:4 (1995), 396. 
108 D. Brunčić, 'Administrative and territorial organization of local self-government and administration', in Brunčić et al. (eds), Legal System of the Republic of Croatia, p. 28.

109 Klemenčić, 'Administrative-territorial division', 397 and n.5, 400.

110 See Government of the Republic of Croatia, Report on the Implementation of Cultural Autonomy of the Members of National Minorities in the Republic of Croatia in 1997 (Zagreb: Government of the Republic of Croatia, 1997).

111 See, for example, A. Kadić, 'Istria in Croatian literature', Journal of Croatian Studies, 20 (1979).

112 Kadić, 'Istria in Croatian literature', 393.

113 M. Klemenčić, V. Kušar and Ž. Richter, 'Changes in the ethnical [sic] structure of Istria: census and spatial analyses 1880-1991', Društvena Istraživanja, 6-7:2 (1993), 607-29.

114 B. Crljenko, 'How old are the Croato-Roman language contacts in Istria?', Društvena Istraživanja, 6-7:2 (1993), 707-21.

115 N. Šetić, 'The beginnings of the modern Croatian nation in Istria - a draught [ sic] for future research', Društvena Istraživanja, 6-7:2 (1993), 587-605.

116 For a discussion of contemporary Croatian claims over Istria see S. Žuljić, Hrvatska Istra: Suvremene Narodnosne Prilike (Zagreb: Nakladni Zavod Globus, 1994).

117 Thompson, A Paper House: The Ending of Yugoslavia (London: Vintage, 1992), p. 89.

118 Thompson, A Paper House, p. 62.

119 V. Žerjavić, 'Immigration and emigration from the Istria, Rijeka and Zadar areas in the period from 1910 to 1971', Društvena Istraživanje, 6-7:2 (1993), 631-56 and P. Ballinger, History in Exile: Memory and Identity at the Borders of the Balkans (Princeton: Princeton University Press, 2002).

120 F. Suran, 'Istrianity as the weaker (or stronger) identity', Društvena Istraživanje, 6-7:2 (1993), 782.

121 Drakulić, Café Europa, p. 164.

122 Author's interview with Nenad Klapčić, secretary of the IDS parliamentary club, Zagreb, 14 September 1999.

123 S. Ramet, Balkan Babel: The Disintegration of Yugoslavia from the Death of Tito to Ethnic War (Boulder: Westview, 2nd edition, 1996), p. 48.

124 Radio Free Europe/Radio Liberté, 2 :12, 22 March 1991.

125 B. Banovac, 'Ethnički identitet i teritorijalna pripadnost: sluchaj istre', Migracijske Teme, 12:3-4 (1996).

126 V. Katunarić, “"Real” and other compatriots: politics of identity in Croatia', in H. Kriesi, K. Armingeon, H., Siegrist and A. Wimmer (eds), Nation and National Identity: The European Experience in Perspective (Zurich: Verlag Ruegger, 1999), pp. 209-10.

127 Katunarić, “Real” and other compatriots', p. 209.

128 Author's interview with Nenad Klapčić.

129 R. Matijašić, 'The early history of Istria and some reflections on modern times', Društvena Istraživanja, 6-7:2 (1993), 569-85.

130 Author's interview with Nenad Klapčić.

131 Author's interview with Nenad Klapčić.

132 Thompson, A Paper House, p. 61.

133 Notes accompanying Istria: Road Map, written by J. Bratulić (Zagreb: Garmond, 1996).

134 Author's interview with Nenad Klapčić. Figures taken from Klemenčić (ed.), A Concise Atlas, p. 62.

135 Klemenčić (ed.), A Concise Atlas, p. 62.

136 Author's interview with Ivan Rimac.

137 Drakulić, Café Europa, p. 252.

138 P. Petrić, 'Istrian graduates on marriage and sexual life', Društvena Istraživanja, 6-7:2 (1993), 797-813.

139 Author's interview with Nenad Klapčić. 
140 Author's interview with Nenad Klapčić.

141 Government of the Republic of Croatia, Report on the Implementation of Cultural Autonomy of the Members of National Minorities in the Republic of Croatia in 1997 (Zagreb: Government of the Republic of Croatia, 1998), p. 9.

142 See S. Balas, 'The opposition in Croatia', in J. Udovički and J. Ridgeway (eds), Burn this House: The Making and Unmaking of Yugoslavia (London: Duke University Press, 1997), p. 271.

143 Istrian Demokratska Sabor, Istrian Democratic Assembly, paper prepared by Ivan Jakovčić (IDS President), Emil Soldatić (IDS General Assembly) and Nenad Klapčić.

144 D. Jović, 'Regional political parties', Društvena Istraživanija, 1:1 (1992), 176.

145 See L. Tindemanns, T. Sommer, S. Veil and D. Anderson, Unfinished Peace: Report of the International Commission on the Balkans (Washington DC: Aspen Institute Berlin/ Carnegie Endowment for International Peace, 1996), p. 105.

146 See M. Foretić (ed.), Dubrovnik in War (Dubrovnik: Matica Hrvatska, 1998).

147 Author's interview with Ivan Rimac.

148 V. Pusić, 'Dictatorships with democratic legitimacy: democracy versus nation', East European Politics and Societies, 8:4 (1994), 391.

149 Pusić, 'Dictatorships with democratic legitimacy', 391.

150 G. Uzelac, 'Franjo Tudjman's [sic] nationalist ideology', East European Quarterly, 31:4 (1998), 460.

151 Uzelac, 'Franjo Tudjman's [sic] nationalist ideology', 460.

152 Uzelac, 'Franjo Tudjman's [sic] nationalist ideology', 460.

153 Uzelac, 'Franjo Tudjman's [sic] nationalist ideology', 460.

154 Uzelac, 'Franjo Tudjman's [sic] nationalist ideology', 460.

155 Večernji List, 28 September 1998.

156 K. E. Basom, 'Prospects for democracy in Serbia and Croatia', East European Quarterly, 29: 4 (1995-96), 317.

157 Bičanić, 'Privatization in Croatia', 436.

158 Klemenčić, 'Administrative-territorial division, 398.

159 Author’s interview with Ivan Rimac. 


\section{6}

\section{The nation in social practice II Language, education and the Catholic Church}

\section{The language question}

Many writers argue that language is one of the distinguishing aspects of a nation. Eugene Hammel, for instance, suggested that in the Balkans, linguistic and religious identification are the primary sources of nationality. ${ }^{1}$ Attempts to form a codified language for the Southern Slavs were a cornerstone of the Illyrian movement in the nineteenth century and both Yugoslav states tried to enforce a standardised state language as a means of avoiding the potentially fractious nature of the national language question. ${ }^{2}$ The significance attached to the unifying aspects of a common Southern Slavic language provoked a reaction among Croatian nationalists in the Yugoslav era. Challenges to the idea of a common South Slavic language was a key component of the Croatian movements in the 1960s, 1970s and 1990s. For nationalist activists, 'the Croatian standard language is for the Croatian nation, just as any other standard languages are for other nations. Croatians do not have any other standard language. The rights of a certain language cannot be determined by the fact that it is more or less similar, completely dissimilar or very similar to some other language."

Because of the perceived importance of language in framing national identity, the language question not only dominated political debate during the Yugoslav period but also continued to create controversy in independent Croatia. In the early 1990s, Vjesnik ran a campaign complaining about the proliferation of English names among new businesses in Zagreb. This campaign was taken up by a HDZ representative in the Sabor who proposed a law stipulating that new firms had to be given Croatian names. The representative commented that such legislation was vital in order to protect the ignorant visitor to Zagreb, who, upon seeing all the English names in shop windows, would mistake the Croatian metropolis for some other world centre such as London or New York. ${ }^{4}$ 
The first systematic attempt to codify a 'pure' Croatian standard language in modern times was carried out by the Ustaša. One of the most significant linguistic changes in this period was the production of an etymological orthography that replaced the phonetic orthography pioneered by the Serbian nationalist linguist Vuk Stefanović Karadžić. ${ }^{5}$ The NDH's Office of Propaganda attempted to purge the Croatian language of Serbian words by publishing a list of words that were forbidden. Anybody found using these words could be prosecuted as a criminal. ${ }^{6}$ Another strategy that the fascists deployed, which was resurrected in the 1990s, was the production of dictionaries designed to show the differences between Croatian and Serbian words. Academics such as Guberina and Krstić produced lists of words that were different in the two languages, resurrecting many words that had been supplanted by 'Serbian-isms' after the formation of Yugoslavia.?

Throughout the socialist Yugoslav era the language question caused conflict between elites in Zagreb and Belgrade. The 1948 Yugoslav constitution recognised 'the equality of all languages' but did not resolve the problem because the languages that were recognised were not named. ${ }^{8}$ Many communist and Serbian writers, such as Jovan Skerlić, argued for the complete unification of Serbian and Croatian languages, while most Croatian intellectuals argued for the recognition of Serbian and Croatian as distinct and equal languages. ${ }^{9}$ There were four distinct periods in this debate: the 1954 Novi Sad Agreement, which established the Serbo-Croatian/Croato-Serbian language; the 1967 declaration of Croatian intellectuals renouncing the Novi Sad Agreement; the 1971 uprising and 1974 constitution; and the shift of emphasis in the 1980s.

In 1954, twenty-five Serbian, Montenegrin and Croatian writers and linguists met in Novi Sad, capital of Vojvodina. Here, they passed a resolution calling for the publication of a common Serbo-Croatian/Croato-Serbian dictionary. The Novi Sad Agreement, which was passed under considerable pressure from the regime in Belgrade, was meant to determine the rules under which a common language for Croats and Serbs could be formulated. These rules were to be based upon the Štokavian dialect spoken throughout Serbia and parts of Croatia (excluding the Zagreb region, Istria and Dalmatia). ${ }^{10}$ For many Croatian writers, the endeavour to create a common language for the Southern Slavs represented little more than a pretext for the propagation of the Serbian language in nonSerbian-speaking regions. ${ }^{11}$ As a result of the Novi Sad Agreement, Matica Srpska and Matica Hrvatska, the leading cultural institutions in Serbia and Croatia at that time, jointly published an orthographic dictionary in 1960. While the various volumes of this dictionary were widely praised by party cadres and intellectuals across Yugoslavia, by the mid-1960s they were criticised by many Croatian intellectuals. ${ }^{12}$ According to Ljudevit Jonke, for example, the first three volumes of the dictionary revealed a preference for the 'eastern variant' (Serbian) over the 'western variant' (Croatian) in cases where there were substantial differences. As a result, Matica Hrvatska pulled out of the joint venture and subsequent volumes were published in Novi Sad by Matica Srpska and became 
increasingly 'eastern' in orientation. ${ }^{13}$ At the same time, other Croatian linguists such as Dalibor Brozović were abandoning the Yugoslav norm of describing the Southern Slavic language as consisting of two variants by identifying a separate 'Croatian language'. This language, Brozović argued, was the language of the Croatian people and not the language of the inhabitants of the Socialist Republic of Croatia. ${ }^{14}$ During the 'Croatian Spring' in 1971, Brozović published his 'ten theses of the Croatian language', which argued that there was a distinct Croatian literary tradition and language.

Discontent about the status of the Croatian language within Yugoslavia and the way it was defined and circumscribed by the Novi Sad Agreement was brought together in the 'Declaration concerning the name and position of the Croatian literary language', published in 1967. Signed by Matica Hrvatska, the PEN club of Croatia (a writers' club), departments in Croatian branches of the Yugoslav Academy of Arts and Sciences, research centres in the Universities of Zagreb and Zadar, and the internationally renowned writer Miroslav Krleža, this declaration represented a direct attack on the Belgrade government's language policy. ${ }^{15}$ It insisted that 'among these attributes, the national name of the language spoken by the Croatian nation is of paramount importance, because it is the inalienable right of every people to call its language by its own national name, irrespective of whether in a philological sense this language is shared in its entirety or through a separate variant by another people'. ${ }^{16}$

The declaration insisted that Croats had a constitutional right to their own language but that this right was being eroded by continual efforts to unify the Croatian and Serbian languages. As if this was not bad enough, it insisted that the new standard language was a reconstituted Serbian tongue. To halt this 'fuzziness', the signatories called upon the central authorities to recognise the existence of four literary languages in Yugoslavia: Slovenian, Croatian, Macedonian and Serbian. ${ }^{17}$ This declaration marked the most overt and direct challenge to Belgrade in the 'Croatian Spring' uprising. Thus the language issue became one of the most heavily politicised and nationalised subjects in Yugoslav Croatia.

In line with an oft-repeated tactic employed by Tito, the propagators of these national linguistic demands were purged from their positions in society, while at the same time many of their demands were granted. The 1974 constitution guaranteed 'the right to belong to a nation or nationality, to express their national culture, and to use freely their language'. ${ }^{18}$ In socialist Croatia's new constitution, which accompanied the new federal constitution, there were several references to a specifically Croatian language. Article 138 of that constitution stated that, 'in the Socialist Republic of Croatia there is in official use the Croatian literary language'. ${ }^{19}$ This legal framework also allowed the Serbian people in Croatia to use their own language. Not only did the 1974 constitution confirm the existence of a Croatian language, it also stipulated that this language was different from Serbian. This led the Zagreb-based linguistic journal, Jezik, to conclude that: 
In light of the fact that the Croatian literary language has received its constitutional sanction in both name as a standard linguistic form for Croats and Serbs in Croatia, as well as equal status with all other languages represented in the Yugoslav federation of republics, there is now a solid foundation for the Croatian language to develop itself in accordance with a natural progress and in keeping with its rich heritage..$^{20}$

Although the constitution identified the existence of a separate language known as Croatian, the state refrained from sanctioning attempts to codify a standard Croatian language and the Novi Sad compromise of 'Serbo-Croatian' or 'CroatoSerbian' remained the official standard language that was taught in schools.

In the 1980s the decentralising tendencies of the 1974 constitution became manifest in language politics. This was reflected in the fact that linguistic studies became ethnically based. One example was a study by Stjepan Sekereš of the dialects of the northern Baranja region of Croatia. Sekereš' study contained separate analyses of the dialects of Serbs and Croats in the region, emphasising that the disparities were caused by ethnic difference rather than by local villageto-village differences. According to Greenberg, in the 1960s such a study would not have distinguished between people according to their ethnicity but rather according to their geographic place. ${ }^{21}$ This 'ethnification' of language resulted in the unwritten rule that scholars should only write about their own national group and in the appropriate national publications. ${ }^{22}$

By 1991 the language question had become one of the defining issues of the national question as a whole. There were two key debates about the relationship between language and national identity. On the one hand there was the question of whether the Croatian language was distinct from Serbian. On the other hand there was the issue of what that Croatian language should look like, given that there has been no generally accepted and widely used Croatian standard language in recent history. Thus the central issue considered here is the claim to an ancient linguistic heritage that was distinct from Serbian, and attempts to establish a new Croatian standard language in the 1990s, which provoked opposition from those who spoke regional dialects and from linguists who claimed that pure Croatian standard languages have little to do with the contemporary vernacular.

Dalibor Brozović insisted that it was possible to define the Croatian standard language as 'an autonomous language, always codified and functionally polyvalent, born in the moment in which a nation, aware of its peculiar identity, started using it as its national linguistic expression within an international community'. ${ }^{23}$ These ideas were crystallised in his 'ten theses' mentioned above. Brozović argued that the Croatian language was the language used by the Croatian nation and that the most important manifestation of this language was the Croatian standard language. This standard language could trace an uninterrupted heritage to the Glagolitic writings of the Middle Ages that developed a 'culturo-linguistic' structure independently of other linguistic traditions. ${ }^{24}$ However, one of the major problems that confronted those who tried to codify a standard Croatian literary language was the extensive linguistic diversity of Croatian society. Not only were there three quite distinct dialects, discussed 
below, there was also little communication between those attempting to develop a standard language and those using different vernaculars to communicate. ${ }^{25}$

The principle claim put forward by those seeking a codified and generally used standard language in contemporary Croatia was that Croatia had an ancient and unbroken linguistic heritage, which resulted in the Croatian language being different from Serbian. Dubravko Škiljan, one of the most renowned contemporary Croatian linguists, pointed towards a tendency to identify a non-Slavic heritage. These linguists argued that the Croatian language had its genesis in Persia and was therefore closer to Persian languages than to Serbian. ${ }^{26}$ Christopher Spalatin, for example, insisted that the Croatian standard language had its beginnings in the sixteenth century in the early writings of the Dubrovnik writers, playwrights and poets. By the eighteenth century, Spalatin argued, the language had been standardised into a common language through the literary activity of Franciscan writers. However, Serbian and Yugoslavist linguists, such as Vuk Stefanović Karadžić, who believed that by writing a common south Slavic language they could unite different peoples into one nation, rudely halted this march to a Croatian standard language. ${ }^{27}$ Nationalist linguists therefore accounted for the diversity of Croatian language by suggesting that the natural course of linguistic development towards a standard had been interrupted by those who developed and later imposed a South Slavic language, which as we saw earlier owed more to Serbian than to Croatian linguistic tradition.

The second important argument made by nationally minded contemporary Croatian linguists was that the vernacular spoken in Croatia constituted a specific language that was identifiably different from either the Serbian language or Serbo-Croatian. According to Celia Hawkesworth, in the 1980s and 1990s language and nation became treated as synonymous throughout Yugoslavia. Where there was once one language called 'Serbo-Croatian' (or 'Croato-Serbian') there became three languages: Croatian, Serbian and Bosnian. Confronted with this confusion, speakers of these languages referred to their language simply as $n a s ̌ k i$, which means 'our language'. ${ }^{28}$ For Daria Sito Sučić, the renaming of languages had little to do with their communicative function and was instead entirely symbolic. She argued that 'what matters is not that people can communicate and understand each other, but that they can call the language they speak by different names'. ${ }^{29}$ However, such views were neither popular nor widely held. Christopher Spalatin's views, first put forward in the 1970s, appeared to be much closer to popular perceptions of language in the 1990s. ${ }^{30}$ For Spalatin, 'Croatians feel the distinctiveness of their language', though he admitted that the differences between Croatian and Serbian were not the same as the differences between French and German but were similar to the differences between Danish and Swedish. ${ }^{31}$ Because of this closeness, there was a need to emphasise the differences that had been downplayed by communist Yugoslavia. As an example, Spalatin pointed to the fact that many Croatian speakers did not differentiate between the sounds made by $\dot{c}$ and $\check{c}$ (see note on pronunciation on page ix). 
Immediately after independence, scholars gathered around the Institut $z a$ Hrvatski Jezik i Jezikoslovlje (Institute of Croatian Language and Linguistics), such as Kačić, and those at the Miroslav Krleža Lexicographical Institute, such as Kaðičić, produced a series of Croatian and Serbian dictionaries that aimed to demonstrate the extent of difference between the languages. Each page of the dictionary was organised into two columns. In the first column was the Croatian word and in the second the corresponding Serbian. ${ }^{32}$ The effect of this concerted effort to promote the difference between Serbian and Croatian was that by the mid-1990s virtually everyone in Croatia referred to their language as Croatian, though the spoken vernacular had not discernibly changed. Furthermore, according to Dubravko Škiljan, this shift occurred without public debate, although other linguists such as Ivan Ivas argued that there had in fact been no resolution to this question. According to Ivas, the case for and against the idea of a separate Croatian language could be sustained depending upon the sociolinguistic criteria employed. Thus in strict linguistic terms it could be argued that Serbian and Croatian are the same language but Ivas argued that this would be to ignore the socio-political aspects of language, which he insisted were crucial. ${ }^{33}$

For many Croatian linguists, the attainment of a standard language was essential for Croatia's accession to full membership of a world of nations. They insisted that language was a fundamental part of their national identity and that the reason why it was still to be fully codified was because the misguided Yugoslavists interrupted the language's natural development. Speculating about the nurturing of language within an independent Croatia, Spalatin had called upon future leaders to establish organisations dedicated to the cultivation of Croatian. ${ }^{34}$ This call was heeded at the end of the 1990s when the two most prestigious academic institutes in Croatia, Matica Hrvatska and the Miroslav Krleža Lexographical Institute began to codify the Croatian language, and, as we saw earlier, there was also an institute founded specifically to investigate and promote the standard Croatian language. In the 1970s Spalatin had insisted that 'the Croatian schools must encourage the new generations to accept and nurture the Croatian standard language with the same love, patriotism and pride as our ancestors built it for us and bequeathed it to us' ${ }^{35}$ As we will see in the next section, this call was taken up with vigour by the education system in the 1990s.

Although the promotion of the standard Croatian language was endorsed by most linguists in Croatia, was manifested in the work of institutes and the influential journal Jezik, and dictated the teaching of Croatian in schools and universities in the 1990s (see below), some linguists argued that the vernacular spoken by most Croats did not actually change. According to Škiljan, Croatia was a largely agrarian and illiterate society until quite recently. He argued, therefore, that we should not pay too much attention to earlier attempts to codify a literary language. Such a language was designed for the intellectual and political elites and had little impact upon the language actually spoken by most Croats. Likewise in the 1990s, there was little communication between the intellectuals who supported a standard language and the majority of vernacular speakers. 
Most people did not buy dictionaries and most children spoke their parents' language rather than the 'pure' Croatian standard that they were taught in the classroom. ${ }^{36}$

Because of this history of illiteracy, language change did not occur through the subtle changes over time in literature but rather through the changes of language instigated by political elites. Dalibor Brozović once called upon Croats to 'speak as the President [Tuðman] speaks', because this was the correct Croatian way to speak. Tuðman was keen to be heard speaking 'pure Croatian', as well as using obscure words that were reputedly 'old Croatian'. He was also credited with founding a host of neologisms. For example, a popular joke contrasted King Zvonimir's curse that Croatia would not be ruled by one who spoke the people's language with the language of Tuðman, which was quite alien to many Croats. However, the President himself was not entirely immune to the old ways. In response to Brozovićs call, in August 1995 Feral Tribune conducted a review of the language Tuðman used and highlighted the frequency with which he used 'Serbian words'.

In August 1995 Vice Vukojević, a HDZ representative in the Sabor, proposed two draft parliamentary bills. In the first, Vukojević proposed that the phonetic alphabet be replaced by an etymological one and that 30,000 of the existing 60-80,000 words be purged from the Croatian language - a proposal that harked directly back to the language restrictions put in place by the $\mathrm{NDH} .{ }^{37}$ The other draft bill aimed to enforce this by establishing a government office for the Croatian language. The office would have a policing function so that anyone found breaking the new language rules could be fined or even imprisoned, depending on how serious the 'violation' was. Although both draft bills were rejected by the Sabor and were resoundingly condemned by large sections of the media and most linguists regardless of their political orientation, they were indicative of the radical Franjoist views of sections of the ruling party. ${ }^{38}$

While education in Croatia will be dealt with in greater detail later, it is worth noting here that language teaching changed greatly after 1991. The Cyrillic alphabet was removed from the curriculum, increasing the estrangement of Serbs and Croats. This produced a common fear among linguists in Zagreb that in years to come Croatian and Serbian would become different languages and that communication between Croats and Serbs could become problematic because of the teaching of a particular type of language in schools. According to Ivan Ivas, language policy went beyond the simple affirmation of a Croatian language and the attempt to re-establish Croatian words that were suppressed by the Yugoslavists. ${ }^{39}$ There developed what Ivas called a 'superCroatian' language. This was a language used by nationalist politicians but was also the language being taught in schools. It included anachronisms and neologisms alongside genuine Croatian words.

For the foreign observer, one of the noticeable things about language changes in Croatia was the way in which this new language represented a step back from globalised standard words. For example, the Serbo-Croatian word 
for airport was aerodrom, a word that would be instantly recognisable not only to English speakers but also to speakers of most European languages. Aerodrom was replaced by the 'Croatian' for airport, zračna luka. While this is technically correct, given that zrač means 'air' and luka is the Croatian word for a port or harbour, it seems bizarre that linguists should 'discover' an old Croatian word for airport probably predating the arrival of air transport in Croatia. Interestingly, Croatian-English dictionaries continued to contain an entry for aerodrom, and according to road signs Zagreb, Split and Dubrovnik still have an aerodrom, though duty-free shopping bags declare that Zagreb has a zračna luka. Another example of this was that the 'Serbian' word for football, fudbal, which was again akin to the German and English words for this sport, was replaced by the Croatian nogomet. While this was a legitimate and often-used Croatian word, it is interesting that the word was used to distinguish Croatia from Serbia. Following a football match in Belgrade between Croatia and Yugoslavia in 1999, Croatian television proclaimed the 'victory' of nogomet over fudbal. Another example of super-Croatian could be found in the subtle change of the Croatian word for sport. Prior to the 1990s, the Serbian, Croatian and Serbo-Croatian word for sport was sport. Croatian linguists agree that sport is a Croatian word and that there is no 'old Croatian' word that has been defiled by sport. However, for reasons that we can only speculate about, towards the end of the 1990s Croatian television broadcasts began referring to sport as šport (see note on pronunciation on $\mathrm{p} . \mathrm{x}$ ). As such, many Croats began to use the word šport rather than sport, while the Langenscheidt English-Croatian dictionary insisted that sport was the Croatian word for sport in all its manifestations. The only explanation was that the new šport sounds similar to the German for 'sport' and makes the Croatian sound distinct from the Serbian word.

The standard-bearer of the new Croatian literary language was the linguistic journal, Jezik. Founded in 1952 as 'a journal for the cultivation of the Croatian literary language', its editor was always considered to be the leader of the Croatian language movement. ${ }^{40}$ In 1979 the hardline communist, Stipe Šuvar wrote that 'the militant nationalistic policies advocated by a group of people around the journal Jezik ... cannot and should not influence our scholars and teachers' ${ }^{41}$ In contemporary Croatia, much of what was taught in schools and universities was based upon research published in Jezik. This research tried to demonstrate the independence and unity of the Croatian language in all the fields of linguistics. For example, in phonetics several writers endeavoured to show that words such as tijelo (body or constitution) and dijete (child) should be pronounced in two syllables rather than the three prescribed by SerboCroatian grammars. ${ }^{42}$ As well as work on semantics, the journal also 'established the vitality of the suffix in contrast to Serbian linguists', and 'flatly refused to even consider the use of the hyphen', which was added to some Serbian words. ${ }^{43}$ Both Dubravko Škiljan and Ivan Ivas identified Jezik as the focal point for the attempt to codify a new Croatian standard language and much of its earlier work on differentiation came to form part of the language taught in schools. 
There were two principal obstacles in the way of those who wished to codify a new Croatian standard language in the 1990s. First, as we have seen, there was little communication between intellectual elites who 'refused to even consider the use of the hyphen' and the majority of people who used the vernacular in social practice. Furthermore, while nationalist oriented newspapers such as Vjesnik and Večernji List attempted to incorporate the new linguistic rules and words into their journalism, other publications such as Feral Tribune, Novi List and Jutarnji List tended to write in a vernacular that was far removed from the official orthography. This meant that the Croatian language put forward by Jezik was considerably different to the language spoken on the streets. This problem was exacerbated by the existence of three distinct dialects. Labelled according to their word for 'what', these three dialects are called Štokavian, Kajkavian and Čakavian. Each is quite different from the other in terms of lexicography and structure, to the extent that a speaker of one dialect that is not conversant with the other may find communication with speakers of other dialects problematic. Furthermore, the dialects are rigid. According to Škiljan, a Cakavian speaker from Split who lived for many years in the Kajkavian dialect area around Zagreb would not change dialect over time. ${ }^{44}$

Geographically, most of Croatia speaks the Štokavian dialect, a dialect that forms the basis of the Croatian standard that was shared with the Serbs and was spoken throughout Bosnia and Hercegovina. Štokavian was spoken in Slavonia, Kordun (around Gospić), Lika (Dalmatian interior) and southern Dalmatia, to Dubrovnik. Within this dialect there are two key variants, which reputedly emerged in the Middle Ages. These are a western and eastern variant, with the eastern being closer to the Serbian standard language. The Kajkavian dialect is perhaps the smallest dialect if judged by geographic area but has many speakers because it is the dialect spoken in Zagreb and its environs and as far north as Varaždin, close to the Hungarian border. The dialect with possibly the most variance is Cakavian. This dialect is spoken in Istria, Kvarner (Rijeka), Dalmatia (Zadar, Šibenik and Split) and on most of the Adriatic islands. Istria has its own particular variant (Čakavica), as does the Zadar region, which also has an Italian heritage. The islands also offer an interesting variety of dialects. On the island of Korčula, for example, each village has its own variant and the difference between the dialect of the town of Vela Luka (on the western tip of the island) and the town of Korčula (on the eastern tip) is great. Because the existence of such well defined and rigidly demarcated dialects also served as a form of regional identification, there was little discernable weakening in the use of such dialects, despite the crusade to establish a standard language. Daria Mateljak Bartulin, former head of the government's media relations department and resident of Zagreb, for example, expressed her wish that her young daughter be brought up to speak the Čakavian dialect rather than a 'standard language'. ${ }^{45}$ However, she also recognised the importance of learning the standard language as this was central to academic and professional success. This seems to indicate that there is a disjuncture between the language used in formal and written com- 
munication and the language used for everyday verbal and non-formal communication. The significance of the differences between the dialects prompted Ivan Ivas to suggest that if the aim of the new linguistic politics in Croatia was to devise a language that was completely different from Serbian, a better route would have been to base the standard on Čakavian or Kajkavian, which are considerably different from the Štokavian-based dialects spoken by Serbs. ${ }^{46}$

For many writers, then, language was the primary source of national identification in the Balkans. The evidence certainly suggests that the HDZ thought so throughout the 1990s. Building on a tradition of linguistic nationalism that was a recurrent theme of academic debate during the Yugoslav period, the HDZ attempted to inculcate a new official language. The first move in doing this was to determine that Croatian and Serbian were separate languages. Linguists in Croatia and abroad were divided on whether they were one language or not. However, the government was insistent that Croatian was a distinct language. To make the standard language properly Croatian, linguists gathered around two important institutions and devised dictionaries that emphasised the differences between Croatian and Serbian. 'Old' Croatian words were reintroduced and some new Croatian words were invented to describe modern phenomena that had only been previously described in 'Serbian'. However, there was a crucial disjuncture between the standard written language and spoken Croatian. Strong regional dialects meant that in some regions spoken Croatian and Serbian were very similar, whereas in other areas the dialect was based upon different sets of rules to those of basic Štokavian.

Although Škiljan claimed that there was no debate in Croatia about the future of language, it was possible to see opposition in the 1990s. The first cleavage, which sparked as much debate outside Croatia as in it, was the question of whether Croatian and Serbian were different languages. By the end of the 1990s very few Croats argued that they were the same language. The more contentious debate, however, concerned what the Croatian language should look like. This was a debate between purists and anti-purists. Purists wished to see thousands of words purged from the dictionary while anti-purists did not. According to Ivas, the public greeted the orthographical work of linguistic nationalists with shock because new and previously unheard of words began to appear in the media, in schools and in politicians speeches. An 'old Croatian' word that has not been used for over half a century may as well be a completely foreign word to those too young to remember it. Ivas defined this sort of language as 'superCroatian', a language of the elite. This was a language used to prove the pure Croatian credentials of the speaker. However, it was also a language that was far removed from that used by most Croats and emphasised the distance that had emerged between the nationalist ideologues within and close to the HDZ and the people the party considered to be its constituency. The emphasis on a particular form of Croatian language produced a reaction. As we saw earlier, the Istrians promoted their own dialect and Novi List included a weekly section written in this dialect. 


\section{Education}

According to an OSCE report published in 1999 'the formative role of the education system in the maintenance of identity is widely understood' ${ }^{47}$ For modernists like Ernest Gellner a modern education system is an essential part of the nationalizing process because 'mass education alone can endow its citizens with self respect and a sense of identity' ${ }^{48}$ According to Anthony Smith, the aim of a public mass education system is to 'unify them around certain shared values, symbols, myths and memories' ${ }^{49}$

Immediately prior to 1918 Croatian school textbooks were written in the spirit of Yugoslavism that derived from the Croatian lllyrianist movement of the previous century. However, despite this general theme, Charles Jelavich observed that there was little treatment of the histories and backgrounds of other Yugoslav peoples and that no detailed knowledge about other nations was imparted through textbooks. This forced Jelavich to conclude that 'the educational system of Serbia and Croatia did not adequately prepare students for South Slav Union in 1918' ${ }^{50}$ After the establishment of the royal dictatorship in 1929, Croatian textbooks stressed an idealised picture of the three constituent nations (Serbs, Croats and Slovenes), emphasising their common links and 'constant desire' for a unified South Slavic state. ${ }^{51}$ However, Wolfgang Hopken noted two key problems with this new Yugoslav education. First, the idealised portrayal of harmony between the three nations was at odds with the political reality of post-1929 Yugoslavia. Second, the vision of Yugoslavia contained in these textbooks was a decidedly Serbian vision. History textbooks focused on the history of the Serbian royal dynasty, and the history of Yugoslavia was embedded in the history of the Serbian state..$^{52}$ In Tito's Yugoslavia, textbooks focused on non-national issues in order to avoid marginalising one or other national group. Thus the Yugoslav identity pursued in the textbooks was a nonnational identity based upon the common struggle of all nations and nationalities for self-management socialism against the forces of fascism..$^{53}$ Ideological rather than civic unity was promoted, which, according to Wolfgang Hopken, 'simply produced a set of codes necessary for behaving in conformity with the existing political system, but nothing like an identification with the system' ${ }^{54}$

After the 1974 Yugoslav constitution, education throughout Yugoslavia began to display nationalist traits at the expense of a Yugoslav orientation. Croatia, however, was an exception to this trend. Under the education policy espoused by the hard-line communist ideologue Stipe Šuvar, Croatian textbooks continued to contain a heavy anti-nationalist stress up to 1990. In 1988, for example, the proportion of the history curriculum taken up with Croatian national history was only 12 per cent compared with 37 per cent in Macedonia. ${ }^{55}$ This prompted widespread fears that national identity was losing the historical basis that was essential for the historical statehood narrative. In terms of content, it is interesting to note that Croatian history textbooks in the 1980s did not make too much distinction between Croats and Ustaša, and although they did 
add tales of atrocities committed by Četniks to their stories of Ustaša crimes, the negative side of the Partisan campaign (particularly the massacres at Bleiburg) was nowhere to be found in the textbooks. ${ }^{56}$

After independence, it was soon recognised that the education system would have to be reformed. Not only should the new education system better reflect Croatia's national history, it was also important for the system to inculcate a new set of Franjoist values among the young. According to the State Institute for the Protection of Family, Maternity and Youth, reform of the education system was important for:

Abandoning the system of education that was monolithic and egalitarian, unsensitive $[s i c]$ to individual differences between children and not tolerating versatility of educational goals and approaches as well as real-life models in families, parents and their children are now enabled to choose an institution (state, private and religious) and program (state and alternative) according to talents, preferences and needs ${ }^{57}$

Education reform was about inculcating post-communist values such as choice and diversity and escaping the homogenising educational goals prescribed by the communist regime. It was believed that such an approach to education would also inculcate Western, liberal values, given that in the course of their education, children and youth are taught in the spirit of peace, understanding, tolerance and respect for the natural environment' ${ }^{58}$ Moreover, the education system was described as 'open, democratic and anticipative. In this sense, it is becoming ever more compatible with educational systems of European countries. ${ }^{39}$ Thus, in articulating the aims and purposes of the Croatian school system, the Ministry of Education and Sports insisted that 'the Croatian school should be human', the 'development of the Croatian school-system should lead to the creation of identity of the Croatian school', and 'the Croatian school system is based on European cultural values' ${ }^{60}$ The inculcation of these values was converted into the guiding principles for education reform in Croatia in combination with Croatian national values. The six guiding principles identified by the Ministry were: Croatisation, which we were told 'was neglected in former Yugoslavia'; (re)connection with Croatian educational tradition; pluralism and democracy; life-long education; the attainment of an all-embracing and mixed education system; and the development of the European dimension in education, including education for peace and minority rights education. ${ }^{61}$

What is interesting about these guiding principles is that, as we saw with the portrayal of the economy, ideas of 'Croatisation' were linked to ideas of 'democracy', 'Europeanism' and 'humanism'. There was a conscious effort to separate what was considered to be Croatian and what was considered to be communist. As such, Branka Baranović argued that the impetus for reform was provided by two 'ideological determinants'. The first was the need to build a new school system that could fulfil the role of creating a new nation-state. The second was the requirement that the school system remove all traces of socialist and 
Yugoslav values in the education of the young. These processes were part of a wider process labelled 're-traditionalisation'. ${ }^{62}$ Baranović argued that the new education authorities gave themselves the role of promoting a 'national renewal' that 'implied a moral and spiritual renewal of the youth through the promotion of ethnic cultural values' ${ }^{63}$ Baranović insisted that the most significant change to the Croatian curriculum was not the inculcation of European or democratic values but that 'ethnic culture entered the school curricula'. ${ }^{64}$ For example, in 1991 Vjesnik wrote that 'the story of our country, the beautiful Croatian patriotic songs, historic heroes and poetry of old Croatian writers present true refreshment in teaching language and literature, music, history and the arts' ${ }^{65}$ For Baranović, the 'ethnification' of the school system reflected the more general ethnification of Croatian society that was deliberately produced by the HDZ. More generally, Hopken noted that 'strengthening national identity is now the unquestioned leading goal in education in all post-Yugoslav republics' with 'the new textbooks obviously intend[ing] to demonstrate an entirely separate past in order to legitimize a separate future' ${ }^{6}{ }^{6}$

The impact that the national curriculum had on the delivery of education throughout the country was significant because the system was centralized, with all pupils following the same curriculum. What was more, the curriculum specified particular authorised textbooks and deviation away from those books was not tolerated by the Ministry. This meant that the standard approach taken by textbooks was the only approach or opinion to which pupils were exposed. The Ministry closely regulated the content of teaching, as teachers could only use textbooks specifically authorised by the Ministry. The levels of co-ordination between ministry, publishers and authors in devising a standard approach was immense. Even the school book publishing company was owned by the state. ${ }^{67}$ The Croatian curriculum was mandatory for all schools. National minorities (including Serbs) were also compelled to follow this curriculum, although they did have the right to follow it in their own language. ${ }^{68}$ The Zavod za Školstvo, a professional pedagogic supervisory board, was abolished and replaced by direct supervision by the Ministry. ${ }^{69}$ What Previšić described as 'totalitarian onemindedness' led to the denigration of alternative proposals for curriculum changes. Opponents of the government's view were often labelled as 'Yugonostalgics' or 'agents of foreigners'. Previšić noted that 'alternative [educational] initiatives are too often labelled as "ideologically nostalgic" for the former regime'. ${ }^{70}$ The result of this rigidly enforced curriculum was that 'after three years, we are not speaking of Croat-centric textbooks, those that have Croatia in the centre of their attention, but of truly Croatian textbooks. Today there is almost nothing that would reflect socialism or Yugoslavism in our textbooks'. ${ }^{71}$

The education reforms were also enforced through the co-option or coercion of teachers. The autonomy of schoolteachers diminished greatly in the 1990s. Headteachers were declared to be 'government officials of particular social importance' and it was mandated that they be appointed by the Ministry and be 
responsible directly to it. ${ }^{72}$ Headteachers were given much greater power to regulate and control the work of teachers and the contents of lessons. They were often appointed because of their affiliation with the HDZ. ${ }^{73}$ As a result the quality of teaching deteriorated - something that was not helped by a shrinking education budget. According to the OSCE, in 1999 only 3.7 per cent of the state budget was reserved for education. This is a figure well below the 6 per cent recommended by UNESCO. ${ }^{74}$ There was no new investment for school buildings, recruiting teachers, or improving their meagre salary. This contributed to overcrowding in urban schools, reducing the number of contact hours between teachers and pupils. ${ }^{75}$ Job insecurity among teaching staff also increased substantially. Teachers were pressured into being 'ideologically correct' in their methods and many who had taught subjects deemed to have a Marxist content had their positions terminated. ${ }^{76}$ In 1992 the Ministry demanded that only Croatian teachers could teach literature courses, although this was retracted in 1994. ${ }^{77}$ The Ministry wielded direct control over schools in order to maximise the impact of its new curriculum and ensure that there were no deviations. It also ensured that there were no deviations in the way that teaching was delivered by directly appointing and regulating headteachers and giving those headteachers wide powers to enforce teaching content and style.

The area of the new curriculum that aroused most attention was the provision for history teaching - an area of particular concern for a government that wanted to sustain its own interpretation of the historic statehood narrative. According to the OSCE, new history textbooks focused specifically on Croatia and the Croats. ${ }^{78}$ In Croatian history textbooks of the 1990s 57 per cent of the space was taken up by exclusively Croatian history. This national history was presented through the history of the Croatian state, its territory and the Croatian people. Furthermore, nearly half of the sections on Croatia and the Croats focused on the 'national suffering' of the Croats and less than 8 per cent of the books looked at the histories of other Yugoslav nations. Most tellingly, only 3 per cent of the space in the books analysed talked about similarities between Croats, Serbs, and Bosnian Muslims, whereas many pages were filled with stories of ethnic conflict. ${ }^{79}$ The OSCE found that the new history textbooks contained high levels of intolerance towards other national groups, particularly towards Serbs. It noted that on many occasions references to Serbs were preceded with adjectives such as 'barbarous', 'uncivilised' and 'brutal'. ${ }^{80}$ The didactic centrepiece of new history textbooks was the historical statehood narrative. ${ }^{81}$

The revisionism in history teaching is best described by looking at how two recent historical periods were portrayed in textbooks. In Ivo Perić's textbook the Second World War period was reinterpreted considerably. We noted earlier that, in Tito's time, Croatian textbooks made particular reference to Ustaša crimes but hardly referred to Partisan crimes. These tendencies were now completely reversed. In the 1990s Croatian textbooks did not mention Ustaša atrocities in any detail and viewed the NDH period as a legitimate expression of the aspiration for Croatian statehood. Whereas the Partisans and Četniks were 
accused of orchestrating a planned genocide against the Croats, Ustaša crimes were portrayed as an 'understandable reaction' to prior injustices. ${ }^{82}$ For example, Perić wrote that 'many Croats who were not interested in politics, who were not Ustashas [ $s i c]$, but simply Croatian patriots, experienced the formation of the $\mathrm{NDH}$ as the coming of a long-awaited national state. ${ }^{83}$ Typical of the nationalisation of history was Perićs analysis of the Ustaša crimes. Perić distinguished between the NDH as a manifestation of the will of the Croatian people and the nature of the Ustaša government. He noted that 'the Ustasha [sic] prisons were full of well-known Croatian writers, painters, sculptors, composers, scientists, priests, educators, athletes ${ }^{8}{ }^{84}$ However, his only reference to the mass murder of Serbs and Jews was to admit that the Ustaša committed genocide against the Jews and that 'they also terrorised a part of the Serbian population'. ${ }^{85}$

Many teachers believed that the quality of historical learning deteriorated as a result of the new curriculum and textbooks. Many found that the pupil's comprehension of Croatian history was impaired without a good appreciation of world and Yugoslav history. ${ }^{86}$ Furthermore, it was noted that the curriculum did not include a historiography section asking why we should study history, and pupils were not presented with different opinions on historical events. ${ }^{87}$ History textbooks (by Ivo Perić) only offered historical narrative and only one perspective on that narrative. There were no references to different historians or perspectives. Baranović suggested that the reason for this may be found in the Ministry's own justification for the teaching of history. The new course outline on the teaching of history produced by the Ministry insisted that history should be 'a weapon of political struggle'. ${ }^{88}$

Changes to the history curriculum were also discernible in the treatment of the recent past. According to Hopken, a process of 'de-Yugoslavisation' was at work here. The Croatian Yugoslavist and Illyrianist movements were described as 'illusionist' and given considerably less space than they enjoyed prior to the 1990s. ${ }^{89}$ Ivo Perić's textbooks portray both Yugoslavias as essentially 'greater Serbias' that caused the continuous suppression of the national rights of the Croatian people..$^{90}$

The government responded to many of these criticisms in its reply to the OSCE report on education mentioned earlier. On the issue of the reinterpretation of the Second World War, the Ministry insisted that it is ... correct that the terror of the partisans and communists is described, which is logical since in the previous regime it was forbidden to write about the suffering of the Croats in Bleiburg of their Calvary'. ${ }^{91}$ The reinterpretation of history was thus legitimised in terms of the one-sided approach to teaching history in the former Yugoslavia. However, rather than opening up the subject to a plurality of views and historical opinion or even merely providing the established historical facts about the Second World War, the new curriculum offered an approach reminiscent of the communist approach but with the over-emphasis shifted from the crimes of the Ustaša to the crimes of the Četniks and Partisans. While the Ministry did not deny that it reinterpreted history in the new curriculum, it did deny that 
other nations were portrayed in an unnecessarily unfavourable light. It argued that 'it is entirely untrue that particular nations are satanised and labelled. The crimes are condemned, as well as the uncivilized and barbaric behaviour of those who committed them, and that is done with the intention of teaching the pupils in ethics and morals and to keep an open mind in order to understand different cultures, through the truthful interpretation of historical events. ${ }^{92}$

A second area of the curriculum that was substantially revised was literature. In the 1990s the literature curriculum was transformed by the introduction of Croatian writers that were unfamiliar to many people, including professors in the linguistics faculty at the University of Zagreb. ${ }^{93}$ The new textbooks did not contain a single text from Serbian literature. They considered Serbian literature to be 'a radical diversion from the century-old school-literary tradition'. ${ }^{94}$ The new literature textbooks made it appear 'as if other nations and peoples do not even exist'. ${ }^{9}$ Thus the literature curriculum for the seventh and eighth grades stated among its tasks and purposes the aims of: '[the] development of homeland feelings and feelings of responsibility to the homeland', 'acquaintance with Croatian cultural heritage' and the 'development [of] abilities of comparing the Croatian and European cultural heritage'. ${ }^{96}$

In essence, the course was a history of Croatian literature charted chronologically rather than thematically and included nothing from European or any non-Croatian literature. The most notable absences from the curriculum were the nineteenth-century Illyrianist poet, Ljudevit Gaj, and the Nobel Prize for literature winner, Ivo Andrić. In 1831 Gaj wrote the famous nationalist poem Još horvatska nije propala, but presumably his views about forming a South Slavic union made him inappropriate for inclusion in the literature curriculum. Although Andrić was born in Travnik, a Bosnian of Croatian parents, his famous work The Bridge over the Drina, an internationally renowned classic, primarily portrays relations between Serbs and Bosnian Muslims and presumably cast neither of them in a negative enough light. ${ }^{97}$ Andrić's other works, such as his Bosnian Chronicle, presented a Bosnian rather than Croatian 'world view' and was thus presumably contrary to the desire to foster the 'homeland feelings' that the course aimed to produce. ${ }^{98}$

The curriculum began by covering what is generally regarded to have been the first Croatian book (The Missal). It went on to look at the renaissance literature of Dubrovnik, with the work of Marko Marulić and Ivan Gundulić. It included an analysis of the writings of the nationalist conspirators Petar Zrinski and Krsto Frankopan, who were included because of their nationalist role rather than for the quality of their writings. Although the Illyrian movement was taught briefly, there was no reference to Gaj or Strossmayer and the only text that was considered was a piece entitled 'Croatian fatherland' by Mihanović, a relatively obscure writer on the fringes of the movement. Of the twentiethcentury writers, only Tin Ujević and the famous Miroslav Krleža were taught and the texts of theirs that were used were selected very carefully so as to portray an appropriate image. ${ }^{99}$ The re-traditionalisation of the literature curriculum 
meant the exclusion of writers who were not purely Croatian or who did not portray suitably Croatian themes, and their replacement with obscure writers or historical figures whose literary endeavours were of little international renown.

A third area of the school curriculum that aroused controversy was religious education. According to the OSCE, international law demands 'the liberty of parents to ensure the religious and moral education of their children' ${ }^{100}$ This right was heavily circumscribed in the former Yugoslavia, since all religious tuition was banished from schools and disincentives were used to prevent individuals from taking religious instruction outside. After independence, the Croatian state moved to ensure that access to religious education was offered to all school pupils. However, it did not provide a state curriculum on religious education aimed at teaching pupils about different religions and issues of ethics and morality. Instead, optional religious education was offered to all pupils and was provided by the different religious communities themselves. This meant that the majority of pupils were taught religious education by Catholic nuns. This in itself created a number of pedagogical problems. How, for example, could a Catholic nun teach moral issues surrounding abortion in a balanced way or provide an adequately nuanced account of Islamic theology? The latter issue was avoided because religious education did not include the teaching of alternative religions. What is more, while religious education was technically optional, it was effectively compulsory. No alternatives to religious education were offered and those who 'opted out' were often singled out as being 'different' from the rest of the class and subjected to abuse from both pupils and teachers alike. For those following Catholic instruction in religious education, attendance at Sunday Mass was a compulsory element. This raises the question of whether the purpose of religious instruction was education or conversion. The idea that elements of curriculum change owed more to promoting Church attendance than to promoting education in religious matters could be seen in the justifications for changes. In 1990 Vjesnik reported that as part of the cleansing of Marxist ideology from school textbooks it was necessary to 'free' them from 'atheist indoctrination'. ${ }^{101}$

Processes of 'Croatisation' and 'de-Yugoslavisation' were thus at work in the changes to the teaching of history, literature and religious education in Croatian schools. In the latter two subjects, this involved the process of retraditionalisation identified earlier, whereby changes were legitimised by the claim that they represented a return to previous, truly Croatian, social practices. Thus the Croatian literary tradition was purged of all non-Croatian elements and the provision of religious education attempted to emphasise the links between Catholicism and Croatian national identity. Meanwhile, the teaching of history persevered with the communist pedagogic tradition of offering a sanitised account of Croatian history that avoided making young Croats face up to some of the more unpleasant aspects of their own national history and did not encourage students to think critically about historical events or to look at them from different perspectives. The core aims and objectives of history teaching in 
Croatia did not change with the change of regime. All that changed were the core values that history was used to inculcate - from communism to nationalism.

One centre of opposition to this education regime was the Open Society Institute (OSI) in Zagreb. Part of George Soros' East European network, the OSI ran many projects in areas such as law monitoring, fostering culture and civil society, and economic reform. ${ }^{102}$ The education programme aimed to 'raise education levels to the best international standards' through the application of 'contemporary learning methods'.$^{103}$ It attempted to promote 'critical thinking' and internationalism. ${ }^{104}$ Other than specific teaching and exchange programmes, the OSI tried to foster critical thinking about the provision of education in Croatia and questioned the curriculum's aims and objectives. In 1998 it participated in the international 'forum for freedom in education' that allowed educators in Croatia to work on common problems with colleagues from across Europe. ${ }^{105}$ This forum also brought together educators and members of the opposition parties. The OSI had planned to include the Ministry of Education in this project but the Ministry refused to participate. ${ }^{106}$ Another way that the OSI sought to enhance the quality of education and introduce pupils to different ideas was through a scheme to donate one computer with an internet connection to every school in Croatia. However, the Ministry refused to accept the computers, arguing that the internet would 'weaken the morality of children'. ${ }^{107}$ Furthermore, the Ministry actively discouraged headteachers from working with OSI, though where headteachers did want to co-operate with the institute it was often achieved through unofficial means.

As part of the process of 'de-Yugoslavisation', the government initially supported the founding of private and alternative schools as a way of promoting the pluralism that went hand-in-hand with post-communist politics. However, by 1993 it had become clear that having alternative schools meant that the Ministry could not completely regulate the content and style of education. After 1993, therefore, alternative schools were tolerated but the education authorities refused to co-operate with them. This meant that they had to be entirely selffunding and could not benefit from any technical assistance from the state. This threatened the existence of many alternative schools and although many continued to exist, particularly in Zagreb and Istria where educational innovation was more notable even in state-run schools, they existed within a hostile environment.

Although the government claimed that its educational policies enhanced the 'morality' of the young and promoted new post-communist values, social marginalisation and resultant 'anti-social behaviour' increased among the young. One particular problem was that of psychological disorder, which according to the State Institute for Motherhood, Family and Youth more than tripled in the second half of the 1990s. ${ }^{108}$ While the most obvious cause of this problem was the psychological effect of the war, particularly among refugees, other problems that were identified included widespread child abuse, poor living conditions and low career prospects. ${ }^{109}$ Although the education system aimed to 'encourage 
children and youth to adopt a healthy life style', evidence suggested that smoking, drug taking and under-age sex increased. ${ }^{110}$

The education system in Croatia was openly used as a political tool by the new Croatian state. Continuing the organisational traits of the communist system, the new curriculum was designed to inculcate a rigid set of values rather than independent thought. Under the previous regime these were the values of self-management socialism and 'brotherhood and unity', but the new values were overtly conservative and nationalist, invoking what the Ministry described as 'homeland feelings' and embedding a particular interpretation of the historic statehood narrative. These new values were the values of Franjoism discussed in Chapter 4 . These processes could be seen in the three curricula considered here. History was taught as a singular narrative in which Croatia preserved its ancient statehood and was victimised by other nations. Manifestations of Croatian fascism and atrocities committed by Croats were removed from textbooks or explained away as understandable responses to systematic oppression. As with the previous regime, pupils were not encouraged to think critically or to engage in historical debate. Similarly, the literature curriculum gave the impression that the Croats developed separately from the other Yugoslav nations and shared a literary history with Europe. Not only were all non-Croatian writers purged from the curriculum, but internationally renowned Croatian writers whose work was not aligned to the Franjoist cause were removed as well. The provisions for religious education were self-consciously aimed at reversing the atheistic trends of communism. Thus the majority Catholic education, which was provided not by the state but by the Church, aimed at conversion rather than education and could not properly address secular issues of morality or citizenship. In this way, Tuðman's idea that Catholicism was an essential component of Croatian identity was actively enforced though the education system.

The education system differed from all the previous studies here by the fact that opposition was muted. The full power of the state was used to enforce a particular dominant account of national identity. At the outset, there was little disagreement about the need to reform the communist education system. The government manipulated this general consensus more easily than the consensus on the need for reform of the economy because it was able to regulate virtually every area of the delivery and content of education. Not only did the state devise the curriculum according to its own needs and ideas, it also published the textbooks and regulated the appointment and activities of headteachers, who in turn had a broad mandate to control individual teachers. Because the state controlled the education system's finances there was little room for deviation. The rhetorical commitment to pluralism was abandoned in 1993, meaning that alternative schools had to be entirely self-financing and received little or no support from the state. Moreover, the government refused to co-operate with organisations such as the OSI, fearing that this may lead to pluralisation and the introduction of alternative ideas. Rather than creating a new generation of Croatian nationalists who accepted the Franjoist account of national identity, 
however, the education reforms contributed to alienation. Many people who worked in this area at the OSI and Institute of Social Research in Zagreb feared that re-traditionalisation reduced the quality of school education and that the new leviathan in education would produce a two-tiered society in the future. On the one hand there would be good Catholic Croats, who read dubious Croatian literature and could recount the centuries of Croatian suffering, while believing that talk of Ustaša atrocities was 'Yugo-nostalgic'. On the other hand, there would be an army of unemployed and alienated youth.

\section{The Roman Catholic Church}

According to Franjo Tuðman, the Croatian Catholic Church was the only institution to consistently resist the communist authorities. Tuðman insisted that by doing so, the Church was responsible for nurturing Croatian national identity during the dark period of communist rule. ${ }^{111}$ Many people within the Church itself shared this view of the relationship between Church and nation. Friar Ilija Živković, Secretary to the Croatian Bishops Conference and head of the Croatian Catholic radio station, argued that through its very existence the Church acted as a voice for the nation and helped to perpetuate Croatian identity, for example by allowing the singing of the Croatian national anthem during Church services. ${ }^{112}$ Likewise, Cardinal Kuharić, head of the Croatian Church until his death in 1996, argued that the Church should try to secure the 'freedom to live and to develop its identity and sovereignty in all areas of life: moral, spiritual, cultural (and) material, finding its expression in statehood' for 'its' people. ${ }^{113}$ Thus it was often claimed that the Church and the nation directly overlapped. To justify this claim, the HDZ government tried to co-opt Catholicism into Franjoism. Nationalists within the Church welcomed this co-option. For example, in 1992 the Catholic journal Veritas published an article by Josip Beljan which declared that 'the cross of Christ stands next to the Croatian flag, the Croatian bishop next to the Croatian Minister of State ... This was truly again a real war for the "honoured cross and golden liberty", for the return of Christ and liberty to Croatia. The Church is glad for the return of its people from the twofold slavery - Serbian and communist. ${ }^{114}$

However, there was considerable debate within the Church about its relationship with the HDZ government and a good deal of unease about many Franjoist policies, especially those perceived to be directed against national minorities or offering cover for corruption and criminality. While the Church leadership advocated tolerance and shied away from supporting the HDZ, many priests - particularly in rural and war-affected parishes - continued to advocate a combination of hard-line nationalism and conservative Catholicism that was similar to the President's views.

Before the formation of the first Yugoslavia there had been a considerable degree of confrontation between the Catholic Church and the Serbian Orthodox 
Church. The Serbs had rejected Josip Strossmayer's ecumenical efforts (see Chapter 3). Moreover, in the nineteenth century the privileges granted by the Sabor to the Orthodox community in the Vojna Krajina caused a 'permanent irritation' to the Catholic Church, which generally regarded the Orthodox Serbs as 'schismatic'. ${ }^{115}$ Subsequently, the Catholic perception of the whole Yugoslav project was generally negative. According to a tract produced by the bishops' conference:

For Catholics, the first Yugoslavia was an inauspicious period, marked by discrimination against the non-Serbian population. This led to hostilities during the Second World War involving great bloodshed, with innocent victims of both sides, including a large number of Catholic priests. The post-war communist regime was antagonistic toward the Catholic Church, nationalizing Church property and openly persecuting members of the Church hierarchy ... Bishops, priests and the faithful were subjected to various humiliations and pressures. ${ }^{116}$

The same document noted that under communism 'attempts to impose atheism on all levels did not wane'. ${ }^{117}$ Ilija Živković offered a similar point of view, arguing that the Church was persecuted by the communists throughout the forty-five years of its rule. ${ }^{118}$ While this is an accurate description of the initial relationship between Church and state in socialist Yugoslavia, by the 1960s the situation had changed considerably. ${ }^{119}$ Stella Alexander noted that in the 1960s the Vatican adopted a conciliatory line in its diplomacy with the Yugoslavs. By 1966 'there was no doubt that better conditions were eventually secured for the Catholic Church than the Bishops could have obtained in 1960'. ${ }^{120}$ Similarly, Sabrina Ramet noted 'unmistakable signs of a new atmosphere of Church-State relations' in the 1960s. ${ }^{121}$ One of the reasons for this was the regime's partial rehabilitation of Archbishop Stepinac after his death. Stepinac's significance to nationalists and Catholics in Croatia was reflected at his beatification. Tuðman commented that the beatification was important for raising the international profile of Croatian Catholics. He added, 'Stepinac was a holy man and one of the wisest Croats during World War II'. ${ }^{122}$ Any visitor to the cathedral in Zagreb in 1999 would have duly noted the gargantuan portrait of Stepinac that adorned the cathedral's facade.

Milovan Djilas, the Yugoslav dissident who had been Tito's right-hand man during the formative years of the communist regime, epitomised the new openness in the 1960s and 1970s with regard to the Catholic Church when he admitted that it was not Stepinac's alleged associations with the Ustaša that had led to his imprisonment but rather his steadfast refusal to break with the Vatican and head an independent Yugoslav Catholic Church. According to Djilas, 'if he had only proclaimed [the creation of] a Croatian Church, separate from Rome, we would have raised him to the clouds! ${ }^{123}$ Thus although the Yugoslav state continued to have misgivings about Catholic activities, there was a discernible easing of tension between Church and state that was not acknowledged by the Church. ${ }^{124}$ 
Around the time of Croatia's first elections in 1990, the Church found itself in a difficult position. It had to defend both itself and its Croatian flock from concerted attack from Belgrade. Efforts by the Croatian communists to continue appeasing the Serbian Orthodox Church were seen as a direct affront by Croatian Catholics. For example, in 1989 the Croatian government paid for the renovation of an Orthodox monastery in Knin, while refusing to given any financial aid for similar schemes involving Catholic churches. ${ }^{125}$ In 1991 Croatian Serb Orthodox bishops refused to condemn the Serbian attack on Croatia and its accompanying ethnic cleansing. One bishop actually saluted the Serb action. ${ }^{126}$

The Church faced two principle issues at this time. On the one hand it was incumbent on it to defend itself and the Croatian people against the hostile chauvinist propaganda emanating from Belgrade, while on the other hand it was taking an increased political role in defence of Croatia's right to selfdetermination. In 1989 Cardinal Kuharić issued a warning about the 'destructive behaviour of the Serbian leadership', which he insisted was aimed at abolishing the 'natural and historical right' Croatian right to sovereignty. ${ }^{127}$ The Church attempted to address these issues in two ways. First, it highlighted the poor human rights conditions in Kosovo and openly supported Kosovar Albanian demands for greater autonomy. ${ }^{128}$ Second, and somewhat controversially, the Church sought to respond directly to anti-Croatian propaganda, much of which focused on Ustaša crimes in the Second World War. The weekly Catholic newspaper, Glas Koncila (Catholic Voice) ran a series of articles in March 1990 that used archival material to show the extent of collaboration between the Serbian Orthodox Church and the Nazi puppet regime in Serbia. ${ }^{129}$

Tuðman's HDZ was the Church's preferred party in the 1990 election. According to Ilija Živković, the tacit support that Cardinal Kuharić offered to the HDZ was based on his belief that the HDZ was a movement of the Croatian people that would seek to improve democracy and lift the shackles of communist rule, thus freeing the Church. ${ }^{130}$ Although it supported the creation of the nationalist-based HDZ and many members of the clergy agitated in favour of the party or sought election as HDZ representatives, the Church hierarchy never openly supported the HDZ and often baulked at Franjoist rhetoric regarding the relationship between Catholicism and nationalism. This early support for the HDZ was not surprising, given the antagonistic relationship between the Church and a Yugoslav state that had often accused it of 'clericalfascism'. ${ }^{131}$ Both Powers and Ramet suggested that the Church's enthusiasm for the HDZ was based on instrumental concerns rather than ideological affiliation. Upon independence, the Church moved swiftly to persuade the new government to return Church property confiscated by the communists and to promote religious education in state schools. Furthermore, as Ramet pointed out, although Kuharić voiced his opinions about political issues such as the proposed confederalisation of Yugoslavia, 'Church elders warned clergy not to become involved in partisan politics' ${ }^{132}$ In particular, there was a major cleavage about the appropriate relationship between the nation and the Church. While Tuðman 
believed the Catholic Church to be a Croatian Church, the Vatican understood itself as a global Church that was as concerned for non-Croats as it was for Croats.

The role of the Catholic Church in the wars in Croatia and Bosnia and Hercegovina attracted a great deal of attention. Paul Mojzes described the wars as 'ethnoreligious' in character and was adamant that the Church contributed to the spiral of violence by propagating ethnic Croatian exclusivism. ${ }^{133} \mathrm{He}$ concluded that 'the Church leadership, together with Franjo Tudjman [sic], made provocative and foolish moves. They pushed their agenda with no regard of the consequences of their behaviour and certainly have to be seen as being among the culprits for the war. ${ }^{134}$ Similarly, Srdjan Vrcan, a Croatian sociologist, argued that the Catholic Church should be blamed for presenting the political, social and national conflicts in the former Yugoslavia 'as centurieslong conflicts between essentially opposed human types, types of cultures and civilisations' ${ }^{135}$ Moreover, he argued that the Church was guilty of portraying the Croats as 'quasi-immaculate' while portraying Serbs as 'the incarnation of evil'. These two positions are a little unfair. Clearly, some priests did articulate such views, which had an open resonance with the language used by Tuðman. However, although Kuharić tacitly supported the HDZ in the run-up to the 1990 election, the Catholic leadership did not call on Catholics to vote for them. Furthermore, the Catholic leadership criticised Croatian ethnic nationalism and war atrocities committed by Croats, and Kuharić steadfastly refused to demonise the Serbs. Finally, on several occasions Catholic prelates denied that the war could be legitimately described as a religious war. ${ }^{136}$

Whatever the role of the Church in supporting Tuðman and propagating the war, there can be little doubt that the JNA and Serbian militias systematically targeted the Church once the war started. According to the Church, one of the reasons for this was precisely because the Serbs did see the war as a religious or holy war. This was because the Serbian Orthodox Church had stood shoulder-to-shoulder with Milošević. As Božidar Javorović put it, the Orthodox Church was guilty of 'transforming religious ceremonies into great political and national meetings that were completely compatible with Milošević's meetings and populist movement'. ${ }^{137}$ Sabrina Ramet described the destruction of Catholic churches in Croatia by Serbian forces as 'nothing short of catastrophic'. ${ }^{138}$ As early as March 1992, she noted, 117 Catholic sacral objects in the Franciscan Province of Split had been destroyed or seriously damaged. By June 1994, around 40 per cent of churches in occupied Croatia had been destroyed or damaged and in 1995 the Church provided detailed evidence that 1,426 Catholic churches in Croatia had been badly damaged or destroyed. ${ }^{139}$ Ramet goes on to contrast this with the fact that in October 1995 it was found that of the 121 Serbian Orthodox churches that were in the so-called Krajina region that was occupied by the Serbs between 1991 and 1995 before the war, only five had been destroyed or badly damaged, 'graphically revealing that the destruction of Catholic churches was the result of premeditated and systematic policy, rather than the random outcome of battles and field action'. ${ }^{140}$ The attitude of 
the Church leadership to the war can be summed up by considering Kuharićs response to Operation Storm, in which the Croatian Army reclaimed the socalled Serbian Krajina. Immediately after the operation, Kuharić concluded that fleeing Serbs had left at the instigation of their own civil and ecclesiastical leaders. He declared:

The fact is that Croatia liberated its territory so that 117,000 expelled Catholic Croats could return. But it is also a fact that the Croatian government did not want the Croatian citizens of Serb nationality to leave their homes. An appeal by the president of the republic to the citizens of Serb nationality, guaranteeing them all rights, freedoms and security and asking them not to leave their homes, was repeated continually. However, I very much regret that people left despite all guarantees. ${ }^{141}$

By October 1995, however, once reports of looting, burning of houses and murders committed by the Croatian Army had been made public, Kuharić used an open-air Mass for 3,500 soldiers and officers to condemn the killing of Serb civilians and other crimes committed by Croatian forces. ${ }^{142}$

The Church orchestrated humanitarian assistance during the war. The Croatian Caritas charity launched a series of major disaster-relief projects that included housing projects for displaced people and the provision of food aid and healthcare assistance. Caritas sponsored 13,000 children in the region and offered financial assistance for the reconstruction of houses for returnees. ${ }^{143}$ In a separate project, Catholics in the USA worked with their brethren in Croatia to put together a team of cardiac surgeons who practised in Croatia during the war. ${ }^{144}$

The Catholic Church was placed in a difficult position by the war. As representatives of an internationalist church, the leadership in Croatia hoped to avoid supporting ethnic exclusivism, but this position became increasingly problematic as the Church itself became a direct target for Serbian attack. Furthermore, many among the clergy (particularly in rural areas) combined conservative Catholicism with Franjoist nationalism. This alliance was manifested in the anti-abortion campaign that was spearheaded by the Church and received considerable backing from the HDZ. The Catholic Church began its anti-abortion campaign in 1987, noting the decline of the birth rate in the predominantly Catholic republics of Croatia and Slovenia as opposed to the other Yugoslav republics. The bishops in Slovenia, for example, noted that the increase of abortions provided evidence of a general 'demoralisation' in society. ${ }^{145}$ The campaign was taken up more rigorously by Tuðman in 1994 when he gave the Ministry of Development and Reconstruction the task of promoting demographic growth and called upon the government to halt the increasing numbers of abortions in Croatia, steps that he claimed were necessary to avoid 'the Croatian people facing extinction' ${ }^{146}$ This campaign was supported by conservative women's patriotic groups, which converged around the State Institute for the Protection of Motherhood, Family and Children. These organisations included the Croatian Population Movement and Hrvatska Žena (Croatian women). Such groups were supported by priests such as Don Anto Baković. 
Baković argued that 'in terms of abortion we still live in Serbo-communism'. ${ }^{147}$ A founding member of the Croatian Population Movement, Baković proposed the stigmatisation of childless couples, the abolition of abortion, the prevention of young women of child-bearing age from emigrating, and the promotion of the concept of the four-child family. ${ }^{148}$ Here again, therefore, we see that although there appeared to be unity of thought between conservative Catholics and the HDZ, this did not produce the sort the alliance between the HDZ and the Church for which Tuðman hoped.

The failure of the HDZ fully to co-opt Catholicism into its national narrative was starkly demonstrated during the first papal visit to Croatia in 1994. The Pope had originally planned to visit Belgrade and Sarajevo as well as Zagreb, but the Serbian authorities refused to allow the visit to go ahead and the UN in Bosnia and Hercegovina refused to guarantee the Pope's security. As such, a visit that was initially meant to be a peace mission to the Balkans became a papal visit to Croatia. ${ }^{149}$ The Pope began by praising the controversial Stepinac and spoke of the tragedy inflicted upon the cities of Vukovar, Dubrovnik and Zadar by the besieging Serb forces. However, he also set himself and the Croatian Catholic Church against the policies espoused by Tuðman and the HDZ, in particular their support for the Bosnian Croats engaged in fighting the Bosnian Muslims. The Pope warned the government against trying to use Catholicism for its own narrowly nationalist ends. In perfect Croatian he warned against 'the risk of idolising a nation, a race, [or] a party, and justifying in their name hatred, discrimination and violence'. ${ }^{150}$ He urged Croatian Catholics to refrain from acts of vengeance, calling on them to 'become apostles [of] a new concord between peoples' ${ }^{151}$ Finally, the Pope condemned the Serb aggression against Croatia but offered the 'kiss of peace' to leaders of the Serbian Orthodox Church. ${ }^{152}$

There can be little doubting the significance of this papal address, which was given to an audience of up to one million people in Zagreb. The Pope openly criticised the government and warned against the central tenet of HDZ nationalism: the positioning of the Croatian nation at the heart of politics. This was reinforced by his oft-proclaimed desire to visit besieged Sarajevo and by his promotion of Vinko Puljić, head of the Church in Sarajevo, to the College of Cardinals. ${ }^{153}$ Puljić was an outspoken critic of the HDZ in Bosnia and Hercegovina, who had denounced the formation of the so-called Croatian republic of Herceg-Bosna, called for multicultural tolerance, and supported peace and cooperation between Croats and Muslims throughout Bosnia and Hercegovina.

The Pope's visit also acted as a catalyst for ecumenical activity in Croatia. In December 1994 Serbian Orthodox services were performed in Zagreb for the first time since the beginning of the war and in 1995 Zagreb Cathedral began making regular use of the 'ecumenical prayer' during its services. In 1997 Cardinal Kuharić's successor, Archbishop Božanić, instigated regular ecumenical meetings between himself and the head of the Orthodox Church in Croatia, Metropolitan Jovan. ${ }^{154}$ The papal visit in 1994 therefore helped to expose the distance between the Church and the HDZ. That distance increased after 1994, 
so much so that the Church began to criticise the government's domestic policies as well as its contribution to the Bosnian conflict.

The subsequent positions taken by the Church on social issues emphasised the growing divide between the HDZ and the Catholic hierarchy. Immediately after the papal visit, Cardinal Kuharić stated that 'if all those in authority had listened to him [the Pope], each in his place ... we would have a far better reputation in the world, a clear conscience and clean hands. As it is, we have only demeaned ourselves'. ${ }^{155}$ Jure Kristo suggested that this conflict was bound to occur sooner or later because of the Church's pronounced support for democracy and human rights - beliefs not fully shared by the ruling party. Kristo argued that as early as 1990 the most prominent Catholic publication, Glas Koncila, was frequently educating its readership in how 'democracy is the highest degree of the Gospel's application in social and state life' ${ }^{156}$ While this early pro-democracy stance can be largely attributed to the Church's strategic interest in seeing the demise of communism, Kristo noted that the Bishops Commission also spoke in favour of pluralistic democracy and warned about the danger of the 'reappearance of fear-inducing methods' utilised by the communists. Furthermore, in a passage that constituted a direct challenge to the basic assumptions of Franjoism, the Commission demanded that political parties 'avoid assuming the exclusive right to interpret recent Croat history'. ${ }^{157}$

The extent of the conflict between the Church and the HDZ can be seen by looking at the former's response to Operation Storm in 1995, noted earlier. A sermon given by Cardinal Kuharić at the time challenged the Franjoist view of the Serbian 'other'. Kuharić asked Croats to do as he did: 'if the opponent burns my house, I will guard his. If he demolishes my church, I will protect his. And if he kills my father, I will safeguard the life of his father. ${ }^{158}$ Following a conference on 'the Church, democracy and general welfare in Croatia' in 1995, the director of the Croatian Catholic Information Agency, Živko Kustić, declared that 'some Croatian nationalists had embraced a form of Nazism'. He continued, 'in a bar in Zagreb I saw a sign reading "no admittance to Serbs". This is a stab into the heart of democracy ... in Croatia there are even official newspapers of neo-fascist and neo-Nazi parties with the following motto below their names: "damned be Serbs, Muslims and Jews, wherever they are". ${ }^{156}$

Archbishop Josip Božanić, used his Christmas address to the nation in 1998 to denounce the 'sinful practices' of the government, focusing in particular on corruption. ${ }^{160} \mathrm{~A}$ similar message was given at Tuðman's funeral on 13 December 1999 when Božanić told an estimated 100,00 mourners that 'he [Tuðman] will enter history as one of the great creators. For all the good Tudjman $[$ sic $]$ did ... we express our deep gratitude and let god be his reward', but continued 'for those things that were less worthy and sinful, let them be forgiven'. ${ }^{161}$ Thus the Church hierarchy tried to distance itself from Franjoism.

Although the Church hierarchy moved against the HDZ government, the Franjoist association of Church and party remained strong in many rural parishes. The Church was deeply divided between a liberal-minded urban leadership and 
conservative-nationalist rural priests and followers who mobilised behind the HDZ's most conservative elements in movements such as the anti-abortion campaign. ${ }^{162}$ The extent of the division within the Catholic Church in Croatia can be seen in responses to the alleged appearance of an apparition of the Virgin Mary in the Bosnian village of Meðugorje. The apparitions began at precisely the time when the Bishopric of Mostar was attempting to assert its authority over the Franciscans who ran many parishes in that area. The Virgin Mary appeared to youngsters that were being taught by the Franciscans, forcing the Catholic authorities to abandon their efforts to exert control over them. Subsequently, the Catholic authorities in Zagreb and Sarajevo unsuccessfully attempted to debunk the apparition claims. Meðugorje became a major site for Christian pilgrimage and the Franciscans retained their status in both Bosnia and Hercegovina and Croatia. ${ }^{163}$ This episode reveals that schisms within the Catholic Church in former Yugoslavia were extensive and deeply felt - extending beyond the realm of nationalist politics into the metaphysical realm of faith and Christian belief.

The Croatian Catholic Church played a vital role in redefining Croatian national identity in the 1990s, but not necessarily the role prescribed for it by the HDZ. During the communist period, the Catholic Church was a symbol of Croatian national identity. It was perceived by nationalists and others as a defining characteristic of national identity. Furthermore, the suffering of the Church under a state that sought to crush it (or at least to force it to sever its links with the Vatican) was seen as emblematic of the wider suffering of the Croatian people. Stepinac's 'martyrdom' fulfilled this function particularly well. Because the Church had had its properties seized and activities curtailed by Tito's regime, it was a keen supporter of democratisation and saw the HDZ as an anti-communist movement. However, it is important to note that while conservative-minded priests openly advocated support for the HDZ and many joined its ranks, the Church leadership never specifically identified itself with Tuðman and indeed spoke out in favour of pluralism and against mono-ethnic politics. The HDZ believed itself to be the party of the Church and Tuðman accorded the Church a leading national role. However, the role of the Croatian government in the Croat-Muslim war that erupted in 1993 caused the Church hierarchy in Zagreb, in tandem with the Catholic Church in Sarajevo, to condemn violent manifestations of Croatian nationalism. This anti-government stance was supported by the Pope's visit to Zagreb in 1994. After 1994 the Church went on to criticise Operation Storm, the government's poor record on human rights, and corruption. It even aired its views at Tuðman's funeral.

Many writers on the Croat-Serb war insisted that religious affiliation was crucial to this 'ethnic war'. Paul Mojzes, for example, described the war as an 'ethnoreligious war'. Similarly, Michael Ignatieff argued that 'Croats' explained that 'the root cause of the bloodshed in the Balkans is that they are "essentially" Catholic ... while Serbs are "essentially" Orthodox'. ${ }^{164}$ Other than being based on the conceit that the war was essentially 'ethnic' rather than 'political' - a 
conceit ably exposed by David Campbell ${ }^{165}$ with regards to Bosnia - this reading was based on a Franjoist understanding of the Church. When Ignatieff used the word 'Croat' he meant Tuðman, the HDZ and its supporters. The leadership of the Catholic Church in Croatia did not concur with Ignatieff's view. While supporting the idea of an independent Croatian state free from communism, the Church actively spoke out against the abuses connected with a narrow Franjoist understanding of national identity. What was particularly interesting about the position taken by the Church leadership was that it frequently invoked conceptions of national identity in order to rebuke the government. The HDZ was accused of bringing shame upon the Croatian nation and by implication of being anti-Croatian because of the policies that it developed to support its narrative of national identity. As a global institution, the Church could not be a national Church. There was therefore a major disjuncture between the internationalist vision of the Catholic Church and the centrality of the Croatian nation for the HDZ. This meant that, as with the Istrian regionalists, elements within the Catholic Church articulated alternative visions of Croatian national identity. However, splits within the Church meant that this was a far from coherent or structured vision.

\section{The nation and social practice}

The previous two chapters have identified six areas of social life where there were daily contests about the meaning of Croatian national identity. These six 'snapshots' offer several insights into understandings of Croatian national identity in the 1990s. We can discern five recurrent themes. These five themes, which are discussed in greater length in the concluding chapter are: Franjoism as a 'nationalising nationalism', re-traditionalisation and ruralisation, diverse sources of opposition, diffuse grounds for opposition, and overlapping and competing identities.

In Chapter 4, opposition to the Franjoist narrative of national identity was identified as emerging from liberal or social democratic political roots and from dissident academics often educated in the West. What these chapters have shown, however, is that opposition arose from many sources and was embedded in social practice. This opposition was not always coherent. Coherence was increased when specific social groups were attacked by Franjoism and organised themselves in response. This was particularly true of the Istrian regionalists and the Bad Blue Boys. In most cases, though, opposition was disparate, disorganised and incoherent. For example, linguists who were united in their opposition to Franjoist language policies, such as Dubravko Škiljan and Ivan Ivas, did not agree on the grounds of their opposition. Furthermore, conceptions of national identity that ran contrary to Franjoism emerged from vastly different roots. Istrian regionalists drew upon the European liberal tradition, trades unionists drew upon social democratic traditions and occasion- 
ally on the principle of social equality that underpinned Titoist economics, and the Bad Blue Boys drew upon their own brand of Croatian nationalism. While it was possible to predict from the earlier chapters that the HDZ would come into conflict with liberal internationalist organisations such as George Soros' OSI, the pattern of government narrative and liberal counter-narrative was not followed across the six areas. While overtly liberal orientations could be discerned in the studies of regionalism and education, when we looked at football and the Church counter-narratives emerged from other forms of nationalism and Christian theology. These patterns of opposition were sharpened by the responses of the different groups to the war. Thus the HDZ often attacked liberals and regionalists for being unpatriotic and questioned their contribution to the homeland war. It portrayed their national narratives as dangerous deviations that could threaten the continued existence of independent Croatia. This accusation was clearly more problematic when directed towards the Bad Blue Boys and the Catholic Church than it was when directed against liberal intellectuals, because both paid a heavy price in the war.

Although the HDZ utilised the full power of the state to mobilise its own view of national identity, it failed to secure Tuðman's dream of a unified and homogenous Croatian polity. Not only was national identity continually reinterpreted through social practice, there was not even agreement on what Croatian nationalism should mean. Different groups and individuals used different traditions at different times, sometimes combining a Franjoist understanding of Croatian state-right with a liberal understanding of what that state should mean, as in the case of the Bad Blue Boys. All this is to suggest, as Paul James does, that it is not possible to reduce processes of nation formation to a single level of social abstraction or core instrumental element.

\section{Notes}

1 E. Hammel, 'The Yugoslav labyrinth', in E. Hammel (ed.), Crisis in the Balkans (Berkeley: Institute of International Studies, 1992), p. 7.

2 For example, see H. Birnbaum, 'Language, ethnicity and nationalism: the linguistic foundation of a unified Yugoslavia', in D. Djordjević (ed.), The Creation of Yugoslavia 1914-1918 (Santa Barbara: ABC-Clio, 1980), pp. 157-82.

3 C. Spalatin, 'The rise of the Croatian standard language', Journal of Croatian Studies, 16 (1975), 15.

4 S. Drakulić, Café Europa: Life after Communism (London: Abacus, 1996), p. 9.

5 D. S. Sučić, 'The fragmentation of Serbo-Croatian into three new languages', Transition, 24:2 (1996), 3.

6 P. Ivić, The Serbian People and Their Language (Belgrade: Srpska Knjizevna Zadruga, 1986), p. 206.

7 Author's interview with Ivan Ivas, Professor of Phonetics, University of Zagreb, 8 September 1999.

8 V. Grubišić, 'The Croatian language in the constitutional development of the Socialist Republic of Croatia and of the Socialist Federative Republic of Yugoslavia', Journal of Croatian Studies, 30 (1989), 139. 
9 C. Spalatin, 'The language situation in Croatia today', Journal of Croatian Studies, 14-15 (1973-74), 3.

10 Editorial, 'Croatian language: from the eleventh century to the computer age', Journal of Croatian Studies, 25-6 (1984-85), 8.

11 Editorial, 'Croatian language', 8.

12 R. D. Greenberg, 'The politics of dialects among Serbs, Croats and Muslims in the former Yugoslavia', East European Politics and Societies, 10:3 (1996), 402.

13 Greenberg, 'The politics of dialects', 402.

14 Greenberg, 'The politics of dialects', p. 403.

15 C. Spalatin, 'Serbo-Croatian or Serbian and Croatian? Considerations on the Croatian declaration and Serbian proposal of March 1967', Journal of Croatian Studies, 7-8 (1966-67).

16 Preamble, 'Declaration concerning the name and the position of the Croatian literary language', 1967.

17 Preamble, 'Declaration', clause 1.

18 Article 170 of the 1974 Constitution of the Socialist Federative Republic of Yugoslavia.

19 Article 138 of the 1974 Constitution of the Socialist Republic of Croatia.

20 Jezik, 26 (1967), 1.

21 Greenberg, 'The politics of dialects', 405, n.33.

22 Greenberg, 'The politics of dialects', 405, n.33.

23 D. Brozović, Standardni Jezik (Zagreb: Matica Hrvatska, 1970), pp. 127-8.

24 Brozović's 'ten theses' are summarised by Spalatin, 'The rise of the Croatian standard language'.

25 Greenberg, 'The politics of dialects', 401.

26 See D. Škiljan, Processes of Ideologization in Language (Zagreb: Centre for Transition and Civil Society Research, 1994).

27 C. Spalatin, 'The Croatian language today', Journal of Croatian Studies, 15-16 (1974-75) 253.

28 C. Hawkesworth, Colloquial Serbo-Croat (Croatian Variant) (London: Routledge, 1986), p. xviii.

29 Sučić, 'The fragmentation of Serbo-Croatian', 1.

30 Author's interview with Dubravko Škiljan, 17 July 1999.

31 C. Spalatin, 'The language situation in Croatia today', 10.

32 Author's interview with Dubravko Škiljan.

33 See D. Škiljan, 'Standard languages in Yugoslavia', in R. Bugarski and C. Hawkesworth (eds), Language Planning in Yugoslavia (Columbus Ohio: Slavica, 1992).

34 Spalatin, 'The rise of the Croatian standard language', 16.

35 Spalatin, 'The rise of the Croatian standard language', 16.

36 Author's interview with Dubravko Škiljan.

37 Sučić, 'The fragmentation of Serbo-Croatian', 3.

38 Sučić, 'The fragmentation of Serbo-Croatian', 3.

39 Author's interview with Ivan Ivas.

40 C. Spalatin, 'A survey of the linguistic periodical Jezik', Journal of Croatian Studies, 25-6 (1984-85), 153.

41 Vjesnik, 4 August 1979.

42 Spalatin, 'A survey of the linguistic periodical Jezik', 155.

43 Spalatin, 'A survey of the linguistic periodical Jezik', 155.

44 Author's interview with Dubravko Škiljan.

45 Author's interview with Daria Mateljak Bartulia, Zagreb, 14 July 1998.

46 Author's inteview with Ivan Ivas.

47 Organisation for Security and Co-operation in Europe (OSCE), Education Rights of Minorities in International Law (Zagreb: OSCE, 1999), p. 1. 
48 A. D. Smith, Nationalism and Modernism (London: Routledge, 1998), p. 31 and Ernest Gellner, Nations and Nationalism (Oxford: Basil Blackwell, 1983), p. 36.

49 Smith, Nationalism and Modernism, p. 41.

50 C. Jelavich, 'Nationalism as reflected in the textbooks of the South Slavs in the nineteenth century', Canadian Review of Nationalism, 16:1-2 (1989), 23. Also see C. Jelavich, South Slav Nationalisms: Textbooks and Yugoslav Union Before 1914 (Columbus Ohio: Ohio State University Press, 1990).

51 W. Hopken, 'History education and Yugoslav (dis-)integration', in M. K. Bokovoy, J. A. Irvine and C. S. Lilly (eds), State-Society Relations in Yugoslavia 1945-1992 (London: Macmillan, 1997), p. 81.

52 Hopken, 'History education', p. 81. Also see C. Jelavich, 'Education, textbooks and South Slav nationalism in the interwar era', in N. Reiter and H. Sundhaussen (eds), Allgemeinbildung als Modernisierungsfaktor: Zur Geschichte der Elementarbildung in Sudeosteuropa von der Aufklärung bis zum Zweiten Weltkreig (Berlin: Harrassowitz, 1994), pp. 127-42.

53 Hopken, 'History education', p. 82.

54 Hopken, 'History education', p. 84.

55 Hopken, 'History education', p. 90.

56 See the textbook: Povijest 2: Udžbenik za Usmjereno Obrazovanje (Zagreb: Skolska Knjiga, 1989).

57 State Institute for the Protection of Family, Maternity and Youth, Children in the Republic of Croatia (Zagreb: State Institute for the Protection of Family, Maternity and Youth, 1999), pp. 17-18.

58 State Institute for the Protection of Family, Maternity and Youth, Youth in the Republic of Croatia (Zagreb: State Institute for the Protection of Family, Maternity and Youth, 1998), p. 10.

59 Children in the Republic of Croatia, p. 18. In some of its publications the Institute translates the Croatian materinstva as 'motherhood' rather than 'maternity'.

60 Ministry of Education and Sports, Starting Points for Strategy of Long Term Development of Education in the Republic of Croatia (Zagreb: Ministry of Education and Sports, 1997), p. 2.

61 Ministry of Education and Sports, The Development of Education: The National Report (Zagreb: Ministry of Education and Sports, 1999), p. 3.

62 B. Baranović, Changes in Secondary School Curricula in Post-Socialist Croatia and Education for Democracy (Zagreb: Institut za Društvena Istraživanja (Institute of Social Research and the University of Zagreb), 1999), p. 5.

63 Baranović, Changes in Secondary School Curricula, p. 7.

64 Baranović, Changes in Secondary School Curricula, pp. 7-8.

65 Vjesnik, 20 May 1991.

66 Hopken, 'History education', p. 94.

67 Author's interview with Vesna Mihoković-Puhovski, Educational Programmes Director for the Open Society Institute (Croatia), Zagreb, 16 September 1999.

68 OSCE, Special Report on Education, (Zagreb: OSCE (Croatia), 30 March 1998), p. 6.

69 V. Previšić, 'Croatian schools facing the challenge of multiculturalism', in V. Katunarić (ed.), Multicultural Reality and Perspectives in Croatia (Zagreb: Interkultura, 1997).

70 Previšić, 'Croatian schools', p. 55.

71 Novi List, 29 January 1994.

72 Baranović, Changes in Secondary School Curricula, p. 7.

73 Author's interview with Vesna Puhovski, 16 September 1999.

74 OSCE, 'Special report on education', p. 3.

75 Author's interview with Vesna Puhovski.

76 Baranović, Changes in Secondary School Curricula, p. 7. 
77 Baranović, Changes in Secondary School Curricula, p. 7.

78 OSCE, Special Report on Education, p. 8.

79 B. Baranović, I. Ivas and A. Hodzić, Education for Peace - A Conflict Resolution Initiative for Post-War Bosnia (Zagreb: IDI and the University of Zagreb, 1999), pp. 3-5.

80 OSCE, Special Report on Education, p. 8. The textbook referred to is I. Perić, Povijest za VIII (Zagreb: Razred Osnovne äkole, 1996), pp. 38-9. Ivo Perić's views about Croatian history can be found in I. Perić, A History of the Croats (Zagreb: CTT, 1999).

81 OSCE, Special Report on Education, p. 8.

82 Perić, Povijest za VIII, pp. 86-7.

83 Perić, A History of the Croats, p. 215. Emphasis added.

84 Perić, A History of the Croats, p. 215.

85 Perić, A History of the Croats, p. 215.

86 Baranović, Changes in Secondary School Curricula, p. 13.

87 Baranović, Ivas and Hodzić, Education for Peace, p. 5.

88 Baranović, Changes in Secondary School Curricula, p. 13, n.3.

89 Hopken, 'History education', p. 95.

90 Perić, Povijest za VIII, p. 134.

91 B. Pugelnik, Minister of Education and Sports, 'Ministry of Education and Sports experts' opinion on the OSCE special report on education in the Republic of Croatia', p. 13.

92 Pugelnik, 'Experts' opinion', p. 17.

93 Author's interview with Ivan Ivas.

94 Baranović, Ivas and Hodzić, Education for Peace, p. 7.

95 Baranović, Ivas and Hodzić, Education for Peace, p. 7.

96 Ministry of Education and Sports, Starting Points, p. 13.

97 I. Andrić, The Bridge over the Drina (London: The Harvill Press, 1995).

98 See I. Andrić, The Bosnian Chronicle (London: The Harvill Press, 1996).

99 Ministry of Education and Sports, Starting Points, pp. 13-20.

100 OSCE , Education Rights of Minorities in International Law, p. 8.

101 Vjesnik, 16 September 1990.

102 Open Society Institute, Open Society Institute - Croatia (Zagreb: OSI, 1999).

103 Open Society Institute, Open Society Institute, p. 3.

104 Open Society Institute, Open Society Institute, p. 3

105 V. Puhovski, Croatia: Community Spirit in Action Education 2000 (Zagreb: OSI, 1999), pp. 4-6.

106 Puhovski, Croatia, pp. 4-6.

107 Author's interview with Simona Goldstein, 23 August 1999.

108 State Institute for the Protection of Motherhood, Family and Youth, 'Themes for ministerial discussion', internal briefing paper, 1999, p. 4.

109 State Institute for the Protection of Motherhood, Family and Youth, 'Themes', p. 4.

110 State Institute for the Protection of Motherhood, Family and Youth, Youth in the Republic of Croatia, pp. 13-14.

111 S. Ramet, Balkan Babel: The Disintegration of Yugoslavia from the Death of Tito to Ethnic War (Boulder: Westview, 2nd edition, 1996), p. 135.

112 Author's interview with Fr Ilija Živković, Zagreb, 7 July 1999.

113 J. Kristo, 'The Catholic Church in a time of crisis', in S. P. Ramet and L. S. Adamovich, Beyond Yugoslavia: Politics, Economics and Culture in a Shattered Community (Boulder: Westview, 1995).

114 P. Mojzes, Yugoslavian Inferno: Ethnoreligious Warfare in the Balkans (New York: Continuum, 1994), p. 130. Also see P. Ramet, 'Religion and nationalism in Yugoslavia', in P. Ramet (ed.), Religion and Nationalism in Soviet and East European Politics (Durham NC: Duke University Press, 1989).

115 J. Udovički, 'The bonds and the faultlines', in J. Udovički and J. Ridgeway (eds), Burn this 
House: The Making and Unmaking of Yugoslavia (London: Duke University Press, 1997).

116 Press Office of the Croatian Conference of Bishops, 'The Catholic Church among the Croats', 1998, p. 1.

117 Press Office of the Croatian Conference of Bishops, 'The Catholic Church', p. 1.

118 Author's interview with Ilija Živković.

119 P. Mojzes, 'The role of religious communities in the development of civil society in Yugoslavia, 1945-1992', in M. K. Bokovoy, J. A. Irvine and C. S. Lilly (eds), State-Society Relations in Yugoslavia (London: Macmillan, 1997), p. 216.

120 S. Alexander, Church and State in Yugoslavia since 1945 (Cambridge: Cambridge University Press, 1979), p. 242.

121 Ramet, Balkan Babel, p. 146. Also see P. Mojzes, 'Religious liberty in Yugoslavia: a study in ambiguity' in L. Swidler (ed.), Religious Liberty and Human Rights in Nations and in Religions (Philadelphia: Ecumenical Press, 1986), pp. 25-6.

122 Croatia Weekly, 35, 1 October 1998.

123 O. A. Benigar, Alojzije Stepinac: Croatian Cardinal (Rome: Ziral, 1974), p. 639.

124 See P. Ramet, 'Catholicism and politics in socialist Yugoslavia', Religion in Communist Lands, 10:3 (1982).

125 Kristo, 'The Catholic Church', p. 434.

126 Kristo, 'The Catholic Church', p. 434.

127 Kristo, 'The Catholic Church', p. 434.

128 P. Mojzes, 'The Roman Catholic Church in Croatia and its contribution to nationalist sentiment', Religion, State and Society, 21:3-4 (1993), 392.

129 Ramet, Balkan Babel, p. 276.

130 Author's interview with Ilija Živković.

131 G. F. Powers, 'Religion, conflict and prospects for reconciliation in Bosnia, Croatia and Yugoslavia', Journal of International Affairs, 50:1 (1996), 231.

132 Ramet, Balkan Babel, p. 158.

133 Mojzes, 'The Roman Catholic Church in Croatia', 393.

134 Mojzes, 'The Roman Catholic Church in Croatia', 393.

135 S. Vrcan, 'Religion and churches and the post-Yugoslav war', in J. Coleman and M. Tonka (eds), Religion and Nationalism (Maryknoll NY: Orbis, 1995), pp. 63-4.

136 Ramet, Balkan Babel, p. 277.

137 B. Javorović, 'Causes and goals of Serbian aggression against Croatia', in I. Živković (ed.), The Wounded Church in Croatia: The Destruction of the Sacral Heritage of Croatia (1991-1995) (Zagreb: Croatian Heritage Foundation and Croatian Conference of Bishops, 1996), p. 67.

138 S. Ramet, 'The Croatian Catholic Church since 1990', Religion, State and Society, 24:4 (1996), 349.

139 Ramet, 'The Croatian Catholic Church', 400.

140 Ramet, 'The Croatian Catholic Church', 400.

141 Živković, The Wounded Church, p. 250.

142 Živković, The Wounded Church, p. 250.

143 Press Office of the Croatian Conference of Bishops, 'The Catholic Church', p. 26.

144 J. Kerrigan and W. Novick, Healing the Heart of Croatia (New York: Paulist Press, 1998).

145 V. Jalušić, 'Women in post-socialist Slovenia: socially adapted, politically marginalized', in S. Ramet (ed.), Gender Politics in the Western Balkans (Pennsylvania: University of Pennsylvania Press, 1999), pp. 117-18.

146 O. Kesić, 'Women and gender imagery in Bosnia: amazons, sluts, victims, witches and wombs', in Ramet (ed.), Gender Politics in the Western Balkans, p. 201.

147 T. Pavlović, 'Women in Croatia: feminists, nationalists and homosexuals', in Ramet (ed.), Gender Politics in the Western Balkans, p. 138.

148 Ramet, 'The Croatian Catholic Church', 346. 
149 Ramet, Balkan Babel, p. 281.

150 Ramet, Balkan Babel, p. 281.

151 Ramet, Balkan Babel, p. 281.

152 Ramet, Balkan Babel, p. 281.

153 Ramet, Balkan Babel, p. 281.

154 Press Office of the Croatian Conference of Bishops, 'The Catholic Church', p. 39.

155 Powers, 'Religion, conflict and prospects', 232.

156 Kristo, 'The Catholic Church', 437.

157 Kristo, 'The Catholic Church', 440.

158 Catholic Press Agency, Zagreb, 3 January 1996.

159 Ramet, 'The Croatian Catholic Church', 348.

160 Author's interview with Ilija Živković.

161 The Times, 14 December 1999.

162 Author's interview with Slaven Lerotić, Zagreb, 23 September 1999.

163 For more on this see M. Bax, 'The Madonna of Medjugorje: religious rivalry and the formation of a devotional movement in Yugoslavia', Anthropological Quarterly, 62:2 (1990); M. Bax, Medjugorje: Religion, Politics and Violence in Rural Bosnia (Amsterdam: VU University Press, 1995); and P. Ramet, 'Factionalism in church-state interaction: the Croatian Catholic Church in the 1980s', Slavic Review, 44:2 (1985).

164 M. Ignatieff, Blood and Belonging: Journeys into the New Nationalism (London: Vintage, 1994), p. 14.

165 See D. Campbell, National Deconstruction: Violence, Identity and Justice in Bosnia (London: University of Minnesota Press, 1998). 


\section{7}

\section{Conclusion}

\section{Competing claims to national identity}

In a seminal work published in 1999, Misha Glenny attempted to plot the Balkan history of the nineteenth and twentieth centuries. Glenny noted that in the 1830s Croatian nationalism began an oscillation between pan-Slavic, proAustrian and anti-Serb orientations. He concluded that this cleavage was the result of 'the multiple cultural and civilisational influences that had influenced the Croats over many centuries [which was] inevitably reflected in Croatian political nationalism'. ${ }^{1}$ Glenny thus offered an instrumental account of Croatian national identity, agreeing with Gellner that nationalism creates nations where none exist. ${ }^{2} \mathrm{He}$ interpreted Croatian national identity as the product of an aggressive nationalism informed by the political interests of social elites. Many other writers, including Ivo Banac, Marcus Tanner and Mirjana Gross, agreed with Glenny about this.

The other prominent approach to Croatian national identity was unmodified primordialism. The encyclopedic work of Francis Eterovich and Christopher Spalatin, the nationalist histories of Ivo Perić and Simon Vladovich, and the cultural histories of Eduard Kale all traced an unbroken line of Croatian history into antiquity. ${ }^{3}$ Here, instrumentalist arguments are inverted: nationalist movements are understood as reflecting national identity rather than vice-versa. Moreover, they use a broader understanding of the nation whereby most instances of group activity can provide evidence of the existence of a prior national or ethnic identity. Furthermore, the meaning of the identity signified by the word 'Croat' was thought to be continuous and essentially unchanging.

The 'great divide' in nationalism studies is therefore reproduced in studies about Croatia. Attempts to understand Croatian national identity have tended to articulate both modernism and primordialism in their most polemic forms. Those who consider Croatian national identity from a modernist perspective reproduce that approach in its most instrumental form. For example, David Campbell suggested that we should treat issues of nationalism and national 
identity 'as questions of history violently deployed in the present for contemporary political goals'. ${ }^{4}$ Campbell understood contemporary Croatian national identity as a tool deployed by the HDZ to secure particular political goals. This approach unwittingly colludes with one of the central myths of Franjoism: the idea that Tuðman/HDZ and the Croatian nation were one and the same. To argue that Croatian national identity was produced by political manipulation is to reject the possibility of alternative understandings and practices of national identity. It is to accept the Franjoist claim that the Croatian nation was a homogenous community of people that shared the President's beliefs.

On the other side of the 'great divide', primordialism was reproduced in its most basic guise. For primordialists, Croats were united through history by a shared statehood that dated back to the medieval kingdom. Simon Vladovich's historical narrative began by explaining the 'Pre-Croat history' of the 'Croatian lands' and then went on to show how the territory became 'Croatianised' in antiquity before revealing how that genealogy was maintained up to the present day. These writers insisted that it is possible to trace a continuous line of history between contemporary and ancient Croatia. For them, Croatian nationalism in the 1990s had much in common with earlier nationalist movements. This view, however, depends on a particular interpretation of history. The nationalist movement in the nineteenth century and subsequent Illyrian movement were mostly cultural and ecumenical movements, while the heart of Croatian politics was in its relations with Austria and Hungary. The agreements of 1526 and 1102 were crucial to supporting the line of continuity between past and present that was central to the historical statehood thesis. This view was reflected in the preamble to the new state's constitution, which traced a continuous line of Croatian nation-statehood from the medieval kingdoms to the present day. According to David McCrone, ' $\mathrm{t}$ ] he time sequences are highlighted because they suggest a seamless continuity, even at those historical conjunctures which would seem to offer embarrassment, such as the fascist regime of the 1940s'. Furthermore, the meaning of Croatian identity was taken to be unproblematic. There was little consideration of regional identity, for instance. The primordialist writers failed to note that until relatively recently there were Croats, Slavonians, Istrians and Dalmatians, with the Croats only being those who lived in the Kajkavian dialect area around Zagreb.

Rather than seeing it as either modern or ancient, either continuous or discontinuous, either homogenous or fragmented, the modern nation should be conceptualised as a social formation that operates at different levels of abstraction. National identity is framed in abstract terms, though in uniting a community of strangers the nation also has resonance in the locale. This resonance depends on the material aspects of the nation, principally the perpetuation of kinship-like ties in social practice. My argument is not that one level is more important than others but rather that national identity depends upon the interaction and interdependence of each level of abstraction (abstract frames, political entrepreneurs and social practice). 
Modernist and primordialist approaches to national identity are incompatible and general in their outlook. They reduce complex processes of social formation to a few 'salient' factors. A modernist account of the formation of Croatian national identity can be rejected because national sentiments were evident a long time before industrialisation and modernisation. Moreover, prior to 1990 (with the exception of 1941-45) the state tended to be mobilised against the idea of Croatian national identity rather than fostering it in the way envisaged by Gellner, Hobsbawm and others. On the other hand, primordialism fails to account for regional diversity and assumes that expressions of national identity had comparable political salience and material resonance over time. The five themes discussed below offer an alternative way of thinking about national identity.

First, they show the relationship between abstract and material manifestations of national identity. Different groups offer competing definitions of national identity often to legitimise different political programmes. This is a two-way process, however. Not only is there a 'top-down' process of political entrepreneurs using abstract frames in order to legitimise particular acts by recourse to notions of common identity and purpose, there is also a 'bottomup' process whereby interpretations of national identity that emerge from social practice come to inform the abstract frames themselves. The failure to appreciate this two-way process can be seen in primordialism's inability to account for radically different conceptions of what being Croatian means and modernism's inability to explain why the identity politics endorsed by various governments and imperial rulers were all ultimately rejected.

Second, these five themes show that the nation can have many different meanings in different times and places. Moreover, invocations of national identity need not signify the same thing. Ljudevit Gaj's 'Croatia' was very different from that of Ante Starčević. More recently, Franjo Tuðman's conception of what Croatian national identity meant was very different to that of many opposition parties and the dissident intellectuals. This was seen, for instance, in the debate about the relationship between Bosnian Croats and Croatia proper.

Finally, these five themes draw our attention to the importance of social practice. Although Anthony Smith recognised the significance of the subjective beliefs that underpin national identity, neither modernism nor primordialism adequately account for the importance of belief and memory in framing understandings of national identity. The latter in particular find it difficult to explain how, as a recent social construction, national identity came to take such a hold on the political imagination. Sometimes a state-sponsored understanding of national identity was not believed by sections of the target group because the understanding of the national experience being put forward was at variance with dominant understandings within that group. This disjuncture tended to result in either reinterpretations of national identity or the formulation of alternative transnational, non-national or regional identities. 


\section{Franjoism as a nationalising nationalism}

Throughout the 1990s the HDZ government attempted to enforce a Franjoist understanding of Croatian national identity. It propagated what Rogers Brubaker labelled 'nationalising nationalism'. For Brubaker, 'nationalising nationalisms involve claims made in the name of a "core nation" or nationality defined in ethnocultural terms, and sharply distinguished from the citizenry as a whole. The core nation is understood as the legitimate 'owner' of the state, which is conceived as the state of and for the core nation.' ${ }^{\prime 6}$ The HDZ departed from Brubaker's understanding of 'nationalising nationalism' inasmuch as it believed that the citizenry and the nation were one and the same. Nevertheless, it defined the Croatian state as the state of the Croatian nation and acted accordingly. In the economic field, Franjoism produced a set of policies that emphasised differences between Croatia's 'Western' economic traditions and 'Balkan'-style economies. A by-product of this, however, was the endemic corruption encapsulated by 'sweetheart loans'. Franjoism was most successful in the field of education because the state controlled virtually all the resources in that area. It was able to control carefully what was taught, who did the teaching and what resources they used. Thus the Franjoist message was passed on to Croatia's youth through the education system. Similarly, the HDZ was able to enforce its ideas about Croatian language by making its own form of language the language of the state and the media.

Stuart Hall argued that control of the past acts as a powerful source of legitimacy for those who attempt to create a new future for a particular group. ${ }^{7}$ Through Franjoism, the abstract frames of the historical statehood thesis were reinterpreted through historical 'truths', images, symbols and rituals. However, Stuart Hall was wrong to imply that there is only one 'narrative' of national identity and history. Moreover, the instrumentalist assumption that the 'invented traditions' produced by Franjoism had an overwhelming resonance is also questionable. Articulating the past and co-opting contemporary social institutions is not always enough to produce the national identities and hoped-for political legitimisation. Perhaps the main reason for this is the pervasiveness of memory. It is well worth joining Tom Nairn in citing Conor Cruise O'Brien on this point:

There is for all of us a twilit zone of time, stretching back for a generation or two before we were born, which never quite belongs to the rest of history. Our elders have talked their memories into our memories until we come to possess some sense of a continuity exceeding and traversing our own individual being. The degree in which we possess that sense of continuity, and the form it takes - national, religious or social - depends on our own imagination and on the personality, opinions and garrulity of our elder relatives. Children if they are imaginative have the power of incorporating into their own lives a significant span of time before their individual births. $^{8}$ 
The perpetuation of individual memory in 1990s Croatia meant that the sharp break from self-management socialism to nationalist conservatism was disingenuous to many. The Franjoist insistence that Yugoslavia impoverished Croatia did not fit with many people's perception of economic realities in the 1980s and 1990s. The argument that Dinamo was a communist and Serbian name did not fit with Bad Blue Boys who could remember when Dinamo represented Croatia and waving a Dinamo flag was a synonym for flying the Croatian flag. The insistence that people must speak one way or another to be proper Croats also floundered when people were required to change the way they spoke. Issues of belief and memory have therefore been present throughout the last three chapters. There was a stark disjuncture between Franjoist claims and experiences of social practice. On the one hand, the state utilised mechanisms of normalisation to enforce its vision of national identity. However, the externalised imaginings of the nation (which provided the focus for Chapters 3 and 4) gain their resonance through processes of internalisation in social practice. Thus 'official nationalisms' cohabit 'with alternative senses of community and structures of feeling. ${ }^{9}$ In many instances in the 1990s, the national culture articulated by the HDZ and the popular culture experienced in the urban centres of Croatia were greatly at odds.

In its response to these challenges, Franjoism became disparate and confused. Despite all the evidence of their patriotism and their sacrifices during the 'Homeland War' (the Croatian name for the Yugoslav wars of succession, 199195), the Bad Blue Boys were derided as 'Yugo-nostalgics' and agents of foreign governments by the government. The Church leadership constantly refused to identify itself with the interests of one nation and began to use the moral authority ascribed to it by Tuðman to openly attack the HDZ. Because of the position that Franjoism awarded the Church, the HDZ was unable to counter the Church's accusations.

\section{Re-traditionalisation and ruralisation}

In the late 1980s Josip Županov introduced the concept of 're-traditionalisation'. The concept traces the emergence of a neo-conservative revolution. This revolution was predicated on the locale and sought to reorder human relationships at the kinship or face-to-face level. It attempted to replicate 'old' societal traditions that had been subjugated by communism. According to Županov, sections of Croatian society believed that 're-traditionalisation' was made necessary by the failure of the Yugoslav authorities to provide for the economic, social and spiritual needs of the people. Although it became clear that 'brotherhood-andunity' and self-management socialism had failed, there was a distinct lack of credible alternatives and thus a tendency towards retrospection.

Writers such as Branka Baranović and organisations such as the OSI insisted that education reform was driven by the idea of 're-traditionalisation'. It was a 
reaction to modernity and an attempt to root Croatian national identity in the pre-modern. Moreover, re-traditionalisation was directly related to Tuðman's interpretation of the historical statehood thesis. It was reflected particularly well in the conservative and Catholic women's groups that sprung up throughout Croatia shortly after the collapse of communism. The re-traditionalisation revolution also fed into the fascist Party of Rights (HSP) programme in the 1990s. Dobroslav Paraga, leader of the HSP, accused Tuðman of being a weak leader and a bad Croat because of his former links with the League of Communists: traditional Croats, we were told, never accepted communism or Yugoslavism.

Another concept used by liberal intellectuals to describe social changes in 1990s Croatia was 'ruralisation'. ${ }^{10}$ Ognjen Čaldarović argued that this was a process that turned Croatia's urban centres into villages: parochial, anti-modern and extremist. ${ }^{11}$ There was, he argued, a physical ruralisation of the cities. During the war there was migration from villages into cities and in particular a large migration of Bosnian Croats into Zagreb and Split. This migration produced social movements that sought to alter urban-cosmopolitan conceptions of national identity within Croatia's metropolitan centres. The presence of larger numbers of rural Croats in urban centres tended to exacerbate extreme ethnic nationalism. Rural Croats tended to support the nationalist agendas of the HDZ, HSP and conservative Catholic groups.

Ruralisation provoked responses in the urban centres, such as the Bad Blue Boys phenomena in Zagreb. According to Čaldarović, at the heart of the Bad Blue Boys' opposition to the regime was a desire to preserve Zagreb's regional identity from what they saw as a challenge from rural migrants. This, Čaldarović argued, meant attempting to preserve a liberal, European, cosmopolitan way of life in the face of the re-traditionalising conservatism of rurality. Indeed, Tom Nairn suggested that the Titoist project attempted to 'impose the values of the city' on South Slavic culture. ${ }^{12}$ Ruralisation and re-traditionalisation therefore represented a rejection of Titoist urbanisation. They juxtaposed themselves to urban cosmopolitanism as a 'real' Croatian way of life juxtaposing itself against a way of life 'invented' by Tito's communism. The urban youth who rejected this ruralised form of national identity were portrayed as anything from degenerates and delinquents to 'Yugo-nostalgics'. The urban-rural divide was a central feature in differing accounts of Croatian national identity. There was an important cleavage, for instance, between the urban Church leadership who refused to embrace the HDZ and the rural clergy who openly supported the HDZ. The politics of ruralisation also crept into the language question with the attempt to ban the use of foreign shop names in cities.

The concepts of re-traditionalisation and ruralisation offer useful insights into the contests about the meaning of Croatian national identity in the 1990s. On the one hand they provide a rationale for Franjoist rhetoric and the policies it spawned, linked, as they were, to Tuðman's interpretation of the historical statehood thesis. However, they also show that the cleavages ran beyond the 
usually cited conflicts between the HDZ and the generally more liberal opposition. There were also rural-urban divides in national identity. This cleavage was most acutely felt in relation to the Bosnian Croats, whose presence in Croatia's urban centres and policy elites aroused much dislike and suspicion.

\section{Diverse sources of opposition}

Opposition to Franjoism occurred in every place where there was a disjuncture between the Franjoist view of Croatian national identity and conceptions of identity that were internalised through social practice. The first and most obvious disjunctures were the competing national narratives articulated by political parties and dissident intellectuals. Opposition parties attacked Franjoism from a variety of angles: rightist and neo-fascist, liberal, centrist and socialist. The neo-fascists, for instance, accused the HDZ of misreading the true nature of Croatian national identity. The bulk of organised opposition to Franjoism, however, emerged from socialist and liberal political parties. It tended to accept the historical statehood thesis that formed the core of the Franjoist narrative. However, it used the frames the thesis provided to highlight the ways that Croatian national identity was historically linked with Central Europe. It accused Tuðman of Balkanising Croatia and called upon Croats to reclaim their true Central European identity and vote for liberal democratic change.

The most radical public challenges to the Franjoist understanding of national identity in the 1990s came from dissident intellectuals. Banac argued that in trying to be all things to all Croats, Franjoism failed to achieve its central goal and instead became distorted and incoherent. ${ }^{13}$ He offered a counterinterpretation of the historical statehood thesis and suggested that concepts such as citizenship and diversity be brought to the fore. He accused Franjoism of offering a one-sided and decidedly limited account of Croatian political traditions.

The previous two chapters identified several areas in which Franjoism failed to have its narrative internalised in social practice. The opposition that this spawned came from an unlikely and diverse variety of social practices. The case that stood out was that of the Bad Blue Boys. Ardent nationalists, skinheads, volunteers for the Croatian army, the Bad Blue Boys nevertheless helped turn the national capital into an opposition power-base. Rejection of Franjoist language policies was widespread. What was described as a new form of 'superCroatian' language, complete with neologisms and words not used since 1918, was imposed on schools, bureaucracies and the media. This was reinforced with the message that all good Croats should speak as the President did. Only a few actually changed the way they spoke, although most Croats did begin to label their language 'Croatian'. Moreover, the school curriculum was challenged by parents and organisations such as the OSI who wished to see a more balanced and less atavistic approach to the teaching of history and literature. 
The groups and individuals that rejected Franjoism were very diverse. Generally speaking there were four types. First, those that rejected Franjoism on political grounds. These were generally either socialists or liberals who disputed the centrality of nationalism or neo-fascists who believed that Franjoism represented a weak form of Croatian nationalism. Second, those who felt that they had been adversely affected by an aspect of Franjoism. The main examples here are the Bad Blue Boys and the Istrians. Third, those individuals who questioned Franjoism on intellectual grounds. Finally, those individuals who silently reinterpreted their own national identity through social practice and the work they did, the language they spoke, the books they read and the company they kept.

\section{Diverse grounds for opposition}

The grounds for opposition were as diffuse as the sources. There were three central themes upon which opposition to Franjoism was based. First, the disjuncture between the rhetoric of Franjoism and experiences of social practice. Second, the internal incoherence of Franjoism itself. This meant that the third theme, the national identity propagated by Tuðman and the HDZ, was perceived by many to be exclusionary rather than inclusive.

There was often a disjuncture between what Franjoism said being Croatian was how and how many people experienced being Croatian in social practice. For instance, according to the state, in 1995 'the fundamental objectives of the economy and policy of transition consists in re-establishing the ties with some essential historical and civilisational trends that were broken by socialism' ${ }^{14}$ For many Croats, if the late 1990s economy reflected the 'civilisational and historical' Croatian economic tradition, Yugoslav economics seemed preferable. For many people, having a Croatian nation-state meant unemployment and a fall in living standards. For them, the economic habits learnt under a communist regime had to be retained. Such disjunctures permeated all six areas of social practice examined in Chapters 5 and 6.

The second key problem with Franjoism was its internal incoherence. By the time of his death, Tuðman was widely seen as an erratic authoritarian. There appeared to be little coherence to what he said or did. He decided that the EU was plotting to re-establish Yugoslavia and to force Croatia into another Balkan union. After the end of the war many critics had trouble distinguishing Tuðman's method of rule from that of Tito. Without a war to wage and a supreme national emergency to guard against, Franjoism became incoherent. Some observers suggested that this was because the Tuðman/HDZ project only had one aim: the achievement and preservation of Croatian sovereignty. Once this had been achieved, it became difficult to know precisely what Franjoism meant. As if to provide answers, Tuðman became more conservative, more radically 'Franjoist' and more dogmatic.

Finally, Franjoism began to exclude more and more people as the 1990s 
wore on. Many of Tuðman's former constituents were alienated. Having been told that Croatia would begin to develop 'normal' politics after the war, many HDZ supporters found that nothing changed and that the President continued to wield the emergency powers he had given himself during the war. This prompted a widespread re-evaluation of national identity and a wholesale rejection of the Franjoist narrative, leading to the heavy defeats endured by the HDZ in the parliamentary and presidential elections of January 2000.

\section{Overlapping and competing national identities}

As the President of all Croats, Tuðman saw a people in his own mould. The Franjoist project attempted to give abstract ideas of national identity a meaning at less abstract levels. It failed because of the rhetorical and practical distance between the Franjoist abstraction and popular perceptions of identity that were embedded in social practice. Evidence of this contradiction was hidden during a war that had an, albeit temporary, homogenising effect on national identity. However, in post-war Croatia the contradictions of national identity were apparent everywhere.

The most obvious articulation of overlapping identity was the multinational Istrian regional identity. Simultaneously, an Istrian could be Croatian, Italian and Slovenian. Istrian 'commonsense' dictated that there was no contradiction in this identity. Istrians moulded a distinct identity out of ambiguity. As a result, they had their patriotic credentials brought into question by being unfavourably compared to the Bosnian Croats, for example.

The issue of overlapping identities was also evident in the study of the Roman Catholic Church. Franjoism identified Croatia as the antemurale christianitatis. According to the HDZ, Croatia was defined by its association with the Roman Catholic Church. For centuries Croatia stood as the bulwark against Islamic and Orthodox Christian expansion into Western Europe. Thus, when Croatia went to war in 1991, 'the cross of Christ [stood] next to the Croatian flag'. ${ }^{15}$ However, the Catholic Church views itself as a multinational and global institution. It would have been incongruous for the Vatican and the Church hierarchy in Croatia to insist that the Croatian nation was special and should be placed at the heart of the political programme at the expense of Bosnian and Serbian Catholics. For Cardinal Kuharić, the primary form of identity was religious faith. This meant that whereas Tuðman was only the President of all Croats, Kuharić had a responsibility to all Catholics in his flock, regardless of their nationality. Thus there was a contradiction at the intersection of religious identity and national identity as defined by Franjoism.

Nations often have different stories to tell. ${ }^{16}$ There are many competing accounts of national identity that emerge from different political and intellectual perspectives and in the daily practices of national identity. National identity is therefore a site of political contestation. Identities overlap with each 
other, with some being more important than others at different times. For example, if two individuals are watching a Croatian football league match between the two largest clubs in Croatia, the most important aspect of their identity may be whether they are from Split, Zagreb, or neither. If those same individuals are listening to a sermon in a Church, the most important question may be whether they adhere to the Catholicism of the Vatican and Zagreb hierarchy or whether they adhere to clericalist nationalism. When these two individuals go shopping, their behaviour and habits may be differentiated by the way that privatisation impacts upon them or whether or not one of them was a member of the HDZ or had an account with a collapsed bank. Each of these three scenarios can tell us something about the individual's national identity but the story may be overlapping and contradictory. For example, the first individual may have been a well-to-do member of the HDZ. However, he/ she may have been a devout Catholic that followed the papal line on issues of human rights and forgiveness. That same person may be from Split, speak a regional dialect, and feel a deep sense of Dalmatian identity that often comes into conflict with the Franjoist view of national identity. Such are the conflicts of national identity within just one individual in only three areas of social life: football, faith and shopping.

\section{Questioning the nation}

Primordialism and modernism tend to portray the nation as a completed project. The nation as revealed here is somewhat different. Here, national identity is seen as an on-going project, or rather the product of many simultaneous ongoing projects. Not only do specific national identities change through time, national identity is itself inconsistent. Most foreign commentators assumed that Croatian national identity was constructed by Franjoism in the 1990s. Most viewed it as a recent construction that had devastating consequences on the region. However, although nations are constituted at the most abstract level, they derive their salience by being embedded in social practice. By itself, the Franjoist claim that Croatia did not relinquish sovereignty to the Hungarians in 1102 was hardly likely to provoke action 890 years later. Indeed, standing by themselves, the claims made in the historical statehood thesis have no meaning in the contemporary context. The important question is how these ideas become salient and how they invoke people to act in certain ways. Both primordialism and modernism offer unsatisfactory answers to this question because they overlook the fact that many different social groups and institutions try to give salience to a particular view of national identity in order to invoke action in support of (or against) a particular political programme. There is therefore an on-going political struggle between different conceptions of national identity. This struggle draws not only on the bureaucratic power of the state but also on interpretations of cultural artefacts and ethnic legacies, non-state institutions 
that might also cross national boundaries, class and economic status, and different experiences of place. Seeing national identity in this way makes it incongruous to view it as static and homogenous, or an end-result of prior social formations. Instead, it must be seen as on-going and fluctuating. Sometimes, between 1991 and 1993 for instance, the competition to provide national identity with meaning appeared to have been resolved. During this period it seemed possible to discern Croatian national identity. It was a Franjoist, conservative and Catholic identity that valourised particular periods of history and vilified sections of society. However, even when the internal Franjoist project was assisted by war and a constant threat to physical security, many people opposed this vision of national identity. Urban liberals and Istrians did not view their national identity in this way. For them, being Croatian had more to do with having a western European world view informed by interconnectedness with Italy and Austria than with a direct lineage to ancient kings.

Viewing national identity as an on-going project avoids teleological and tautological explanations. As well as being a product of competition between different institutions and groups, national identity is itself in constant competition with other forms of collective and individual consciousness. National identity is not always the most salient form of identity, even when the state is using all its power to pioneer a nationalising crusade. At the individual level, personal experience shapes identity. For example, an identity politics based on not being Serbian has little resonance if an individual happens to be married to a Serb or to have a Serbian work colleague. At another level, ideas about national identity constantly compete with other ideas and social institutions. This means that for some people, in some times and places, national identity may hold less resonance than other identities. At a macro level, this became apparent after 1995 where the immediacy of the threat to physical security receded and other - non-national - interests came to the fore of the political agenda. Quite rapidly, the symbols of millennial statehood used by Tuðman became symbols of derision. By 2000 Franjoist national identity had lost its ability to dictate people's political preferences. Predominant understandings of national identity began to emphasise economic, social and international issues, such as the desire to integrate into Western Europe.

The nation is embedded within social practice. While most primordialist and modernist writers agree with this view, they do not allow it to drive their analysis. Primodialists emphasise the importance of individual subjectivity and locate it in the transition from ethnie to nation. However, they do not extrapolate from this the idea that the nation can have as many meanings as there are subjects, nor do they address the contest between different accounts of national identity. Modernists reveal how such national meanings were constructed in modernity but fail to account for how those accounts of national identity come to have such resonance with subjects, to the extent that they became the core organisational principle for many modern societies while on other occasions failing to have such resonance. Analysis of national identity construction in the 
modern era needs to focus on the contexts in which it takes place. National identity is not constructed on a tabula rasa and neither is its construction a oneway process.

There are many other forms of collective identity that operate somewhere between the individual and the nation. Catholics or Istrians also have a collective consciousness and this consciousness has a relationship with both individual subjectivity and national identity. While both these forms of collective consciousness operated within ideas of Croatian national identity they also reached out beyond national identity - Catholicism to the global Catholic Church and Istrians to their Italian and Slovene neighbours. Conceptions of national identity, therefore, are deeply embedded within a diverse array of social settings and individual and collective consciousness.

What, then, do the five themes discerned through the studies on Croatian national identity in the 1990s tell us about national identity in general? Any study that uses Paul James' ontology of 'abstract communities' must see the nation in two ways: ubiquitous and complex. National identity is a form of collective consciousness through which an individual comes to identify with a disembodied group. It is therefore constituted by two relationships. On the one hand, the disembodied group has to be identified. The individual has to know what it is that it is attached to. It is this relationship that primordialism and modernism tend to focus on. This is a relationship that locates the individual within a nation. On the other hand, however, it is important to ask how the nation becomes embodied in the individual through social practice. Traditional approaches tend to assume that the latter will always accompany the former in a way that is unproblematic. However, there is not always close collaboration between the two relationships. The process of embodiment often alters understandings of national identity, creating disputes about both its meaning and salience.

A new way of thinking about national identity is proposed here. This approach draws upon both primordialist and modernist thought but moves beyond them by viewing nation formation as an on-going project. From primordialism, the approach adopted here views national identity as deriving partly from subjective understandings of prior forms of identity and social formation. From modernism, we must appreciate the role of 'nationalising nationalism' and the significance of the socio-political and economic changes that accompanied nation formation. This points the study of nations and nationalism towards an analysis of the on-going competition between different accounts of national identity, resistance to those accounts and to the central role of national identity itself. This is the sort of 'bottom-up' analysis called for but not practised by Eric Hobsbawm. It views nation formation as neither natural, inevitable or complete. Instead, nation formation is an on-going process in which the salience of national identity ebbs and flows with the different meanings given to the nation and the social practices it induces.

Croatian national identity was an indeterminate site of political conflict. The HDZ government failed to inculcate its own vision of national identity 
among the 'national body', despite being able to mobilise the full bureaucratic power of the state and despite the undoubted homogenising effect of the 199195 war. Alternative accounts of national identity flourished. This exposes the weaknesses of primordialist and modernist accounts of national identity and highlights two central points. The first is the two-way relationship between abstract frames, social practices and experiences of national identity. This relationship is further complicated by the interaction of national identity with other forms of collective identity such as regional or religious identity, which transcend state borders. The second is the idea that invocations of national identity do not always invoke the same thing. Croatian national identity may mean different things even in the same time and place. Calling it an ancient artefact or a recent construction is unhelpful because such accounts do not enable us to interpret the meaning and salience of national identity in a given time or place. National identity became so resonant in 1990s Croatia because it was embedded in social practice. Opposition to Franjoism sprang up wherever there was a disjuncture between abstract ideas of national identity and the actual experiences of national identity. Because of their 'top-down' focus, problems of memory and belief do not figure largely in primordialism and modernist accounts, which tend, as a result, to view national identities as fixed and stable.

There is a need for new approaches to national identity that appreciate its complexity and ubiquity and reject the traditional general theories that characterised the 'great divide'. Such approaches should take into account the problems that nationalists are not always believed by their constituents, that different groups within the nation may have different ideas about what the nation means and that these ideas may emerge from multinational collectivities such as the Catholic Church. New approaches should also take heed of Paul James' view that national identity is constituted at an intersection of different layers of abstraction, as failure to do so will continue to limit the explanatory power of 'nationalism studies'.

\section{Notes}

1 M. Glenny, The Balkans 1804-1999: Nationalism, War and the Great Powers (London: Granta Books, 1999), p. 43.

2 E. Gellner, Nations and Nationalism (Oxford: Basil Blackwell, 1983), pp. 48-9.

3 E. Kale, Hrvatski Kulturni i Politički Identitet (Zagreb: Pan Liber, 1999).

4 D. Campbell, National Deconstruction: Violence, Identity and Justice in Bosnia (London: University of Minnesota Press, 1998), p. 86.

5 D. McCrone, The Sociology of Nationalism (London: Routledge, 1998), p. 50.

6 R. Brubaker, Nationalism Reframed: Nationalism and the National Question in the New Europe (Cambridge: Cambridge University Press, 1996), p. 5.

7 S. Hall, 'Ethnicity: identity and difference', in G. Eley and R. G. Suny (eds), Becoming National: A Reader (Oxford: Oxford University Press, 1998), pp. 339-49.

8 T. Nairn, Faces of Nationalism: Janus Revisited (London: Verso, 1997), p. 15. 
9 S. Radcliffe and S. Westwood, Remaking the Nation: Place, Identity and Politics in Latin America (London: Routledge, 1996), pp. 14-15.

10 See J. Allcock, Explaining Yugoslavia (London: C. Hurst and Co., 2000).

11 Author's interview with Ognjen Čaldarović, Professor of Sociology at the University of Zagreb, 14 September 1999.

12 Nairn, Faces of Nationalism, p. 108.

13 I. Banac, 'Croatianism: Franjo Tudjman's brutal opportunism', New Republic, 209:17 (1993).

14 D. Vojnić, 'Economy and the politics of transition: the road to the welfare state and the economy', Croatia Economic Survey (Zagreb: Ekonomski Institut and National Bank of Croatia,1995), 249.

15 Veritas, 9-10 November 1992.

16 M. Billig, Banal Nationalism (London: Sage, 1995), p. 71. 


\section{BIBLIOGRAPHY}

Agnew, J. (ed.) (1997) Political Geography: A Reader, London: Arnold.

Akhavan, P. and Howse B. (eds) (1995) Yugoslavia: The Former and Future, Washington DC: The Brookings Institute.

Alexander, S. (1979) Church and State in Yugoslavia Since 1945, Cambridge: Cambridge University Press.

Alexander, S. (1987) The Triple Myth: A Life of Archbishop Alojzije Stepinac, New York: East European Monographs.

Allcock, J. (2000) Explaining Yugoslavia, London: C. Hurst and Co.

Allcock, J., Horton J. and Milivojević, M. (eds) (1987) Yugoslavia in Transition: Choices and Constraints. Essays in Honour of Fred Singleton, New York: Berg.

Allen, B. (1996) Rape Warfare: The Hidden Genocide in Bosnia-Hercegovina and Croatia, London: University of Minneapolis Press.

Allison, L. (ed.) (1986) The Politics of Sport, Manchester: Manchester University Press.

Almond, M. (1994) Europe's Backyard War: The War in the Balkans, London: Mandarin.

Alter, P. (1985) Nationalism, London: Hodder and Stoughton.

Anderson, B. (1991) Imagined Communities, revised edition, London: Verso.

Andrejevich, M. (1991) 'Relations between Croatia and Slovenia', Radio Free Europel Radio Liberté Report on Eastern Europe, 2:12.

Andrić I. (1995) The Bridge over the Drina, London: The Harvill Press.

Andrić I. (1996) The Bosnian Chronicle, London: The Harvill Press.

Anon. (1944) Jugoslavia: Vol. II History, Peoples and Administration, London: Naval Intelligence Division Handbook Series.

Anon (1998) NK Croatia and the Champions League, Zagreb: NK Croatia.

Anšuić, Z., Rohatinski, Z. and Šonje, V. (eds) (1995) A Road to Low Inflation, Zagreb: Vlada Co.

Armstrong, J. (1982) Nations Before Nationalism, Chapel Hill: University of North Carolina Press.

Auty, P. (1970) Tito: A Bibliography, London: Longman.

Auty, P. and Clogg, R. (eds) (1975) British Policy Towards Wartime Resistance in Yugoslavia and Greece, London: Macmillan.

Avakumović, I. (1971) 'Yugoslavia's fascist movements', in P. F. Sugar (ed.), Native Fascism in the Successor States: 1918-1945, Santa Barbara: ABC-Clio.

Babić, I. (1970) 'Military history', in F. Eterovich and C. Spalatin (eds), Croatia: Land, People, Culture, volume 1, Toronto: University of Toronto Press.

Balas, S. (1997) 'The opposition in Croatia', in J. Udovički and J. Ridgeway (eds), Burn This House: The Making and Unmaking of Yugoslavia, London: Duke University Press.

Balakrishnan, G. (ed.) (1996) Mapping the Nation, London: Verso.

Bale, J. (1993) Sport, Space and the City, London: Routledge.

Ballinger, P. (2002) History in Exile: Memory and Identity at the Borders of the Balkans, Princeton: Princeton University Press. 
Banac, I. (1981) 'Ministration and desecration: the place of Dubrovnik in modern Croat national ideology and political culture', in I. Banac, J. G. Ackerman and R. Szporluk (eds), Nation and Ideology: Essays in Honor of Wayne S. Vucinich, New York: Columbia University Press.

Banac, I. (1984) The National Question in Yugoslavia: Origins, History, Politics, London: Cornell University Press.

Banac, I. (1986) 'Comments', Journal of Croatian Studies, 27.

Banac, I. (1986) 'The redivived Croatia of Pavao Ritter Vitezović', Harvard Ukrainian Studies, 10:3-4.

Banac, I. (1988) With Stalin Against Tito: Cominformist Splits in Yugoslav Communism, London: Cornell University Press.

Banac, I. (ed.) (1992) Eastern Europe in Revolution, London: Cornell University Press.

Banac, I. (1992) 'Emperor Karl has become a Comitadji: the Croatian disturbances of 1918', Slavonic and East European Review, 70:2.

Banac, I. (1992) 'Post-communism and post-Yugoslavism: the Yugoslav nonrevolutions of 1989-90', in I. Banac (ed.), Eastern Europe in Revolution, London: Cornell University Press.

Banac, I. (1992) 'The fearful asymmetry of war: the causes and consequences of Yugoslavia's demise', Daedalus, 119:1.

Banac, I. (1992), 'Introduction', in T. Macan, A Short History of Croatia, Zagreb: Most/ The Bridge.

Banac, I. (1992) 'Historiography of the countries of Eastern Europe: Yugoslavia', American Historical Review, 97:4.

Banac, I. (1993) 'Croatianism: Franjo Tudjman's brutal opportunism', New Republic, 209:17.

Banac, I. (1995) 'The dissolution of Yugoslav historiography', in S. P. Ramet and L. Adamovich (eds), Beyond Yugoslavia: Politics, Economics and Culture in a Shattered Community, Boulder: Westview Press.

Banac, I. (1995) 'Zarathustra in red Croatia: Milan Šufflay and his theory of nationhood', in I. Banac and K. Verdery (eds), National Character and National Ideology in Interwar Eastern Europe, New Haven: Yale Center for International and Area Studies.

Banac, I. (1996) 'Introduction to special issue on the concepts of nationhood in early modern Eastern Europe', Harvard Ukrainian Studies, 10:3-4.

Banac, I. and Verdery, K. (eds) (1995) National Character and National Ideology in Interwar Eastern Europe, New Haven: Yale Center for International and Area Studies.

Banovac, B. (1996) 'Etnički identitet i teritorijalna pripadnost: sluchaj istre', Migracijske Teme, 12:3-4.

Baranović, B. (1999) Changes in Secondary School Curricula in Post-Socialist Croatia and Education for Democracy, Zagreb: Institut za Društvena Istraživanja and the University of Zagreb.

Baranović, B., Ivas, I. and Hodzić, A. (1999) Education For Peace - A Conflict Resolution Initiative for Post-War Bosnia, Zagreb: Institut za Društvena Istraživanja and the University of Zagreb.

Barnes, V. L. (1960) The Second Soviet-Yugoslav Dispute: Full Text of Main Documents, Indiana: Indiana University Slavic and East European Studies Series No. 14.

Barnett, M. (1999) 'Culture, strategy and foreign policy change: the road to Oslo', European Journal of International Relations, 5:1. 
Basom, K. E. (1995-96), 'Prospects for democracy in Serbia and Croatia', East European Quarterly, 29:4.

Bass, R. and Marbury, E. (eds) (1959) The Soviet-Yugoslav Controversy 1948-58: A Documentary Record, New York: East European Institute.

Bax, M. (1990) 'The Madonna of Medjugorje: religious rivalry and the formation of a devotional movement in Yugoslavia', Anthropological Quarterly, 62:2.

Bax, M. (1995) Medjugorje: Religion, Politics and Violence in Rural Bosnia, Amsterdam: VU University Press.

Bedenko, V. (1996), Zagrebački Gradec: Kuća i Grad u Srednjem Vijeku, Zagreb: Školska Knjižara.

Beljo, A. (ed.) (1993) Historical Maps of Croatia, Zagreb: Croatian Information Centre.

Bellamy, A. J. (1999) 'Introducing Nietzsche to the study of nations', Nationalism and Ethnic Politics, 5:1.

Bellamy, A. J. (1999) 'Reclaiming the Croatian Flag', Rethinking History, 3:3.

Bellamy, A. J. (2002), Kosovo and International Society, London: Palgrave-Macmillan.

Benigar, O. A. (1974) Alojzije Stepinac: Croatian Cardinal, Rome: Ziral.

Bennett, C. (1995) Yugoslavia's Bloody Collapse: Causes, Course and Consequences, London: C. Hurst and Co.

Bhabha, H. (ed.) (1990) Nation and Narration, London: Routledge.

Bhaskar, R. (1979) The Possibility of Naturalism: A Philosophical Critique of the Contemporary Human Sciences, 2nd edition, London: Harvester Wheatsheaf.

Bičanić, I. (1993) 'Privatization in Croatia', East European Politics and Societies, 7:3.

Bičanić I. and Škreb, M. (1994) 'The Yugoslav economy from amalgamation to disintegration: failed attempts at moulding a new economic space 1969-1993', in D. Good (ed.), Economic Transformation in Central and Eastern Europe, London: Routledge.

Biegman, N. (1967) The Turco-Ragusan Relationship According to the Firmans of Mirad III (1575-95), The Hague: Moulton and Co.

Billig, M. (1995) Banal Nationalism, London: Sage.

Biondich, M. (1996) 'Stjepan Radić, Yugoslavism and the Habsburg monarchy', Austrian History Yearbook, 27.

Birnbaum, H. (1980) 'Language, ethnicity and nationalism: the linguistic foundation of a unified Yugoslavia', in D. Djordjević (ed.), The Creation of Yugoslavia 1914-1918, Santa Barbara: ABC-Clio .

Bleyer, M. I. and Škreb, M. (eds) (1997) Macroeconomic Stabilization in Transition Economies, Cambridge: Cambridge University Press.

Boban, L. (1990) 'Jasenovac and the manipulation of history', East European Politics and Societies, 4:3.

Boban, L. (1992) 'Still more balance on Jasenovac and the manipulation of history', East European Politics and Societies, 6:4.

Bokovoy, M. K., Irvine, J. A. and Lilly, C. S. (eds) (1997) State-society Relations in Yugoslavia, London: Macmillan.

Bonifačić, A. F. and Mihanovich, C. S. (eds) (1955) The Croatian Nation in its Struggle for Freedom and Independence, Chicago: Cultural Publishing Centre.

Borošak-Marijanović, J. (1996) Croatian Flags Through the Centuries, Zagreb: Hrvatski Povijesni Muzej.

Bracewell, C. (1992) The Uskoks of Senj: Piracy, Banditry and Holy War in the SixteenthCentury Adriatic, London: Cornell University Press. 
Brass, P. (1991) Ethnicity and Nationalism: Theory and Comparison, London: Sage.

Bratulić, J. (1996) Istria: Road Map, Zagreb: Garmond.

Breuilly, J. (1982) Nationalism and the State, Manchester: Manchester University Press.

Breuilly, J. (1996) 'Approaches to nationalism', in G. Balakrishnan (ed.), Mapping the Nation, London: Verso.

Brisby, L. (1986) 'Nationalism revisited', World Today, 26.

Brohm, J-M. (1978) Sport: A Prison of Measured Time, trans. I. Fraser, London: Ink Links. Brozović, D. (1970) Standardni Jezik, Zagreb: Matica Hrvatska.

Brozović, D. (1987) 'Croatian literary language in the eighteenth century', Journal of Croatian Studies, 28-9.

Brubaker, R. (1996) Nationalism Reframed: Nationhood and the National Question in the New Europe, Cambridge: Cambridge University Press.

Brunčić, D., Lučić, Z., Ljubanović, V. and Vrjkić, I. (eds) (1998) Legal System of the Republic of Croatia, Osijek: Collegium, University of Osijek.

Buden, B. (1997) 'Culture and politics', ARKzin, November.

Bugarski, R. and Hawkesworth, C. (eds) (1992) Language Planning in Yugoslavia, Columbus Ohio: Slavica.

Bulajić, M. (1992) Tudjman's 'Jasenovac Myth': Ustaša Crimes of Genocide, Belgrade: Ministry of Information of the Republic of Serbia.

Campbell, D. (1998) National Deconstruction: Violence, Identity and Justice in Bosnia, London: University of Minnesota Press.

Carr, E. H. (1945) Nationalism and After, London: Macmillan.

Carr, E. H. (1964) What is History?, Harmondsworth: Penguin.

Carter, F. W. (1972) Dubrovnik (Ragusa): A Classic City-State, London: Seminar Press.

Carter, F. W. (ed.) (1977) A Historical Geography of the Balkans, London: Academic Press.

Ceh, N. and Harder, J. (eds) (1996) The Golden Apple: War and Democracy in Croatia and Bosnia, New York: Columbia University Press.

Chapman, J. C. (ed.) (1988) Recent Developments in Yugoslav Archaeology, Oxford: Osney Mead BAR.

Chatterjee, P. (1986) Nationalist Thought and the Colonial World, London: Zed Books.

Chatterjee, P. (1991) 'Whose imagined community?', Millennium: Journal of International Studies, 20:3.

Chatterjee, P. (1993) The Nation and its Fragmentation: Colonial and Postcolonial Histories, New Jersey, Princeton University Press.

Cichock, M. A. (1990) 'The Soviet Union and Yugoslavia in the 1980s: a relationship in flux', Political Science Quarterly, 105:1.

Clissold, S. (1979) 'Croat Separatism: Nationalism, Dissidence and Terrorism', Institute for the Study of Conflict Paper No. 103, London: Institute for the Study of Conflict.

Cohen, L. J. (1989) The Socialist Pyramid: Elites and Power in Yugoslavia, Oakville Ontario: Mosaic Press.

Cohen, L. J. (1992) 'The disintegration of Yugoslavia', Current History, 91:568.

Cohen, L. J. (1995) Broken Bonds: Yugoslavia's Disintegration and Balkan Politics in Transition, 2nd edition, Oxford: Westview.

Cohen, L. J. (1997) 'Embattled democracy: postcommunist Croatia in transition', in K. Dawisha and B. Parrott (eds), Politics, Power and the Struggle for Democracy in South-East Europe, Cambridge: Cambridge University Press.

Cohler, A. M. (1970) Rousseau and Nationalism, London: Basic Books. 
Connor, W. (1973) 'The politics of ethnonationalism', Journal of International Affairs, $27: 1$.

Connor, W. (1978) 'A nation is a nation, is a state, is an ethnic group, is a ...', Ethnic and Racial Studies, 1:1.

Connor, W. (1990) 'When is a nation?', Ethnic and Racial Studies, 13:1.

Connor, W. (1994) Ethnonationalism: The Quest for Understanding, Princeton NJ: Princeton University Press.

Constantinou, C. (1994) 'Diplomatic representations ... or who framed the ambassadors?', Millennium: Journal of International Studies, 23:1.

Conversi, D. (1995) 'Reassessing current theories of nationalism: nationalism as boundary maintenance and creation', Nationalism and Ethnic Politics, 1:1.

Crljenko, B. (1993) 'How old are the Croato-Roman language contacts in Istria?', Društvena Istraživanja, 6-7:2.

Crnobrnija, M. (1994) The Yugoslav Drama, 2nd edition, London: I. B. Tauris.

Croatian Chamber of Economy (1998) Croatia Your Business Partner, Zagreb: Croatian Chamber of Economy.

Croatian Helsinki Human Rights Watch (1995) Civil and Political Rights in Croatia, London: Human Rights Watch.

Croatian Investment Promotion Agency (CIPA) (1999) Croatia: Economic Outlook 1999, Zagreb: CIPA.

Cviić, C. (1986) 'Tito's land, Tito’s legacy: myths and counter-myths', Encounter, 66.

Cviić, C. (1991) Remaking the Balkans, London: Royal Institute of International Affairs.

Cviić, C. (1994) An Awful Warning: The War in Ex-Yugoslavia, London: Centre for Policy Studies No. 139.

Cviić, C. (1996) 'Croatia', in D. A. Dyker and I. Vejvoda (eds), Yugoslavia and After: A Study in Fragmentation, Despair and Rebirth, London: Longman.

Čučković, N. (1998) The Grey Economy and the Privatization Process in Croatia, Varna Bulgaria: EACES

Čuvalo, A. (1989) 'Croatian nationalism and the Croatian national movement (19661972) in Anglo-American publications: a critical assessment', Journal of Croatian Studies, 30.

Čuvalo, A. (1990) The Croatian National Movement 1966-1972, New York: Columbia University Press.

Darby, H. C. and Seton-Watson, R. W. (1968) A Short History of Yugoslavia from Early Times to 1966, Cambridge: Cambridge University Press.

De Beaugrande, R., Grosman, M. and Seidhofer, B. (eds) (1998) Language Policy and Language Education in Emerging Nations: Focus on Slovenia and Croatia, Stamford: Ablex Publishing.

De Winter, L. and Tursen, H. (eds) (1998) Regionalist Parties in Western Europe, London: Routledge.

Dedijer, V. (1970) The Battle Stalin Lost: Memoirs of a Yugoslav 1948-53, New York: Viking Press.

Dedijer, V. (1974) History of Yugoslavia, New York: McGraw-Hill.

Dedijer, V. (1992) The Yugoslav Auschwitz and the Vatican: The Croatian Massacre of the Serbs During World War II, New York: Prometheus Books.

Denitch, B. (1990) The Crisis of Yugoslav Socialism and State Socialist Systems, Minneapolis: University of Minnesota Press. 
Denitch, B. (1994) Ethnic Nationalism: The Tragic Death of Yugoslavia, London: University of Minnesota Press.

Deroc, M. (1988) British Special Operations Explored: Yugoslavia in Turmoil 1941-1943 and the British Response, Boulder: East European Monographs.

Despalatović, E. M. (1975) Ljudevit Gaj and the Illyrian Movement, London: Moulton and Co.

Deutsch, K. (1963) The Nerves of Government, New York: Free Press.

Deutsch, K. (1966) Nationalism and Social Communication, 2nd edition, New York: MIT Press.

Dimitrijević, V. (1995) 'The 1974 constitution and constitutional process as a factor in the collapse of Yugoslavia', in P. Akhavan and R. Howse (eds), Yugoslavia: The Former and Future, Washington DC: The Brookings Institute.

Djilas, M. (1985) Rise and Fall, New York: Harcourt Brace.

Djordjević, D. (ed.) (1980) The First Yugoslavia: The Search for a Viable Political System, Santa Barbara: ABC-Clio.

Dokić, N. S. (1992) 'The international community and the case of Croatia and Slovenia', The International Spectator, 27:4.

Dragnich, A. N. (1983) The First Yugoslavia: Search for a Viable Political System, Stanford: Hoover Institution Press.

Dragnich, A. N. (1992) Serbs and Croats: The Struggle in Yugoslavia, London: Harcourt Brace.

Drakulić, S. (1987) Holograms of Fear, London: The Women's Press.

Drakulić, S. (1992) How We Survived Communism and Even Laughed, 1992 edition, London: Vintage.

Drakulić, S. (1992) The Balkan Express: Fragments From the Other Side of War, London: Harper Perennial.

Drakulić, S. (1993) 'Love story: a true tale from Sarajevo', New Republic, 209:17.

Drakulić, S. (1993) 'Mass rape in Bosnia - women hide behind a wall of silence', The Nation, 1 March.

Drakulić, S. (1994) 'Memories of the Tito regime: my fatherland', New Republic, 212:6.

Drakulić, S. (1994) Marble Skin, London: The Women's Press.

Drakulić, S. (1995) 'Mapped out: a Tudjman [sic] fantasy', New Republic, 213:11.

Drakulić, S. (1996) Café Europa: Life After Communism, London: Abacus.

Drakulić, S. (1997) The Taste of a Man, London: Hutchinson.

Durkheim, E. (1896) The Rules of Sociological Method, New York: Free Press.

Durkheim, E. (1965) Montesquieu and Rousseau: Forerunners of Sociology, Michigan: Michigan University Press.

Dusa, J. (1991) The Medieval Dalmatian Episcopal Cities: Development and Transformation, New York, Peter Lang.

Dyker, D. A. and Vejvoda, I. (eds) (1996) Yugoslavia and After: A Study in Fragmentation, Despair and Rebirth, London: Longman.

Einangel, V. I. (1997) 'Croatia: Nationalism and the Birth of a New State', University of Oslo Department of Geography Occasional Paper No. 20, Oslo, University of Oslo.

Eley, G. and Suny, V. G. (eds) (1998) Becoming National: A Reader, Oxford: Oxford University Press.

Emperley, H. M. V. (1919) History of Serbia, London: G. Bell and Sons.

Enloe, C. (1988) Bananas, Beaches and Bases: Making Feminist Sense of International 
Politics, Los Angeles: University of California Press.

Eriksen, T. H. (1993) Ethnicity and Nationalism: Anthropological Perspectives, London: Pluto. Eterovich, F. and Spalatin, C. (eds) (1970) Croatia: Land, People, Culture, volume 1, Toronto: University of Toronto Press.

Evans, M. A. (1989) The Early Medieval Archaeology of Croatia A.D. 600-900, Oxford: Osney Mead BAR.

Fanon, F. (1967) The Wretched of the Earth, Harmondsworth: Penguin.

Feletar, D. and Stiperski, Z. (1996) 'The development and structure of the Croatian economy', Geojournal, 38.

Ferguson, A. (1973) 'A critical literary approach to Miroslav Krleža's "Return of Filip Latinovicz [sic]"', Journal of Croatian Studies, 14-15.

Fine, J. (1983) The Early Medieval Balkans: A Critical Survey from the Sixth to the Twelfth Century, Ann Arbor: University of Michigan Press.

Fine, J. A. (1987) The Late Medieval Balkans: A Critical Survey from the Late Twelfth Century to the Ottoman Conquest, Ann Arbor: University of Michigan Press.

Fink-Hafner, D. and J. R. Robbins (eds) (1997) Making a New Nation: The Formation of Slovenia, Aldershot: Dartmouth.

Fishman, J. (1972) Language and Nationalism: Two Integrative Essays, Rowley MA: Newbury House.

Fishman, J. (1980) 'Social theory and ethnography: neglected perspectives on language and ethnicity in Eastern Europe', in P. Sugar (ed.), Ethnic Diversity and Conflict in Eastern Europe, Santa Barbara CA: ABC-Clio.

Foretić, M. (ed.) (1998) Dubrovnik in War, Dubrovnik: Matica Hrvatska.

Foucault, M. (1977) Discipline and Punish: The Birth of the Prison, trans. A. Sheridan, Cambridge: Cambridge University Press.

Franolić, B. (1988) Language Policy in Yugoslavia with Special Reference to Croatian, Paris: Nouvelles Editions Latines.

Franolić, B. (1993) 'Marko Marulić and Croatian renaissance literature', Journal of Croatian Studies, 34-5.

Franolić, B. (1994) Croatian Glagolitic Printed Texts, Zagreb: Croatian Information Centre.

Frydman, R., Murphy, K. and Rapaczynski, A. (eds) (1998) Capitalism with a Comrades Face, Budapest: Central European University Press.

Gazi, S. (1962-63) 'Beginning of the Croatian Peasant Party: a historico-politico study', Journal of Croatian Studies, 3-4.

Gazi, S. (1973) A History of Croatia, New York: Philosophical Library.

Gazi, S. (1973-74) 'Stjepan Radić: his life and political activities 1871-1928', Journal of Croatian Studies, 14-15.

Geertz, C. (ed.) (1963) Old Societies and New States: The Quest for Modernity in Africa and Asia, New York: Free Press.

Geertz, C. (1993) The Interpretation of Cultures, London: Fontana.

Geertz, C. (1995) After the Fact: Two Countries, Four Decades, One Anthropologist, London: Harvard University Press.

Gellner, E. (1983) Nations and Nationalism, Oxford: Basil Blackwell.

Gellner, E. (1987) Culture, Identity and Politics, Cambridge: Cambridge University Press.

Gellner, E. (1994) Encounters with Nationalism, Oxford: Basil Blackwell. 
Gellner, E. (1996) 'Reply: do nations have navels?', Nations and Nationalism, 2:3.

Giddens, A. (1984) The Constitution of Modernity, Cambridge: Polity Press.

Giddens, A. (1984) The Constitution of Society: Outline of the Theory of Structuration, Cambridge: Polity Press.

Giddens, A. (1985) The Nation-State and Violence: A Contemporary Critique of Historical Materialism, volume 2, Cambridge: Polity Press.

Giddens, A. (1987) Durkheim on Politics and the State, London: Fontana.

Giddens, A. (1987) Social Theory and Modern Sociology, Cambridge: Polity Press.

Giddens, A. (1991) Modernity and Self Identity, Cambridge: Polity Press.

Gilroy, P. (1990) 'Nationalism, history and ethnic absolutism', History Workshop Journal, 30.

Giulianotti, R. and Williams, J. (eds) (1994) Game without Frontiers: Football, Identity and Modernity, Aldershot: Ashgate Publishing.

Gjurgjan, L. (1992) 'Nationalism and women in Croatia', Journal of Gender Studies, 1:4.

Glavas, D. (1994) 'The roots of Croatian extremism', Mediterranean Quarterly, 5:2.

Glenn, J. (1997) 'Nations and nationalism: Marxist approaches to the subject', Nationalism and Ethnic Politics, 3:2.

Glenny, M. (1992) The Fall of Yugoslavia: The Third Balkan War, 3rd revised edition, Harmondsworth: Penguin.

Glenny, M. (1999) The Balkans 1804-1999: Nationalism, War and the Great Powers, London: Granta Books.

Godina, V. V. (1998) 'The outbreak of nationalism on former Yugoslav territory: a historical perspective on the problem of supranational identity', Nations and Nationalism, 4:3.

Goldstein, I. (1999) Croatia: A History, London: C. Hurst and Co.

Goss, V. (1977-78) 'The beginnings of Romanesque architecture in Croatia', Journal of Croatian Studies, 18-19.

Gotovac, V., Tuðman, F. and Veselica, M. (1981) Letters Against the Tyranny, London: United Publishers.

Government of the Republic of Croatia (1998) Report on the Implementation of Cultural Autonomy of the Members of National Minorities in the Republic of Croatia in 1997, Zagreb: Government of the Republic of Croatia.

Gow, J. (1991) 'Deconstructing Yugoslavia', Survival, 33:2.

Gow, J. (1992) Legitimacy and the Military: The Yugoslav Crisis, London: Pinter.

Gow, J. (1997) Triumph of the Lack of Will: International Diplomacy and the Yugoslav War, London: C. Hurst and Co.

Grabovac, I. (ed.) (1995) 450 Years of Croatians in Canada, Calgary: Croatian Studies Foundation.

Graham, S. (1939) Alexander of Yugoslavia: The Story of the King who was Murdered at Marseilles, New Haven: Yale University Press.

Granić, S. (1993-94) 'The Croatian coat of arms: historical emblem or controversial symbol?', Journal of Croatian Studies, 24-5.

Granić, S. (1999) 'The symbols of Croatian statehood as presented in the print media', Gaudeamus, 18.

Grdešić, I. (1992) '1990 elections in Croatia', Croatian Political Science Review, 1:1.

Grdešić, I. (1996) 'The development of political science in Croatia: meeting the challenges of democracy and independence', European Journal of Political Research, 29. 
Greenberg, R. D. (1996) 'The politics of dialects among Serbs, Croats and Muslims in the former Yugoslavia', East European Politics and Societies, 10:3.

Grlica, G. (1973) 'Trumbić's policy and Croatian national interests from 1914 to the beginning of 1918', Journal of Croatian Studies, 14-15.

Gross, M. (1979) 'Croatian national-integrational ideologies from the end of Illyrism to the creation of Yugoslavia', Austrian History Yearbook, 15-16.

Gross, M. (1981) 'On the integration of the Croatian nation: a case study in nation building', East European Quarterly, 15:2.

Gross, M. (1985) Počeci moderne Hrvatske. Neoapsolutizam u civilnoj Hrvatskoj i Slavoniji 1850-1860, Zagreb: Globus.

Gross, M. (1993) Suvremena Historiografija: Korijeni, Postignuača, Traganja, Zagreb: Novi Liber.

Gross, M. (1993) 'The union of Dalmatia with Northern Croatia: a crucial question of the Croatian national integration in the nineteenth century', in M. Teich and R. Porter (eds), The National Question in Historical Context, Cambridge: Cambridge University Press.

Grubišić, V. (1989) 'The Croatian language in the constitutional development of the Socialist Federative Republic of Yugoslavia', Journal of Croatian Studies, 30.

Guibernau, M. (1996) Nationalisms: The Nation-state and Nationalism in the Twentieth Century, Cambridge: Polity Press.

Guldescu, S. (1964) History of Medieval Croatia to 1526, The Hague: Moulton and Co.

Guldescu, S. (1970) 'Political history to 1526', in F. Eterovich and C. Spalatin (eds), Croatia: Land, People, Culture, volume 1, Toronto: University of Toronto Press.

Guldescu, S. (1970), 'Croatian political history 1526-1918', in F. Eterovich and C. Spalatin (eds), Croatia: Land, People, Culture, volume 2, New York: Philosophical Library.

Guldescu, S. (1970) The Croatian-Slavonian Kingdom 1526-1792, The Hague: Moulton and Co.

Guttmann, A. (1986) Sports Spectators, New York: Columbia University Press.

Haas, E. (1993) 'Nationalism: an instrumental social construction', Millennium: Journal of International Studies, 22:3.

Hall, J. A. (ed.) (1998) The State of the Nation: Ernest Gellner and the Theory of Nationalism, Cambridge: Cambridge University Press.

Hall, P. (1997) 'Nationalism and historicity', Nations and Nationalism, 3:1.

Hall, S. (1998) 'Ethnicity: identity and difference', in G. Eley and R. G. Suny (eds), Becoming National: A Reader, Oxford: Oxford University Press.

Hammel, E. (1992) 'The Yugoslav labyrinth', in E. Hammel (ed.), Crisis in the Balkans, Berkeley: Institute of International Studies.

Harris, P. (1992) Somebody Else's War: Frontline Reports From the Balkan Wars, Stevenage: Spa Books.

Harvey, A. (1997) 'Review of Paul James, "Nation Formation"', Australian Journal of Political Science, 32:2.

Hastings, A. (1997) The Construction of Nationhood, Cambridge: Cambridge University Press.

Havel, V. (1990), 'The power of the powerless', in J. Keane (ed.), The Power of the Powerless, London: M. E. Sharpe.

Hawkesworth, C. (1986) Colloquial Serbo-Croat (Croatian Variant), London: Routledge. 
Hawkesworth, C. (1996) 'How to be a witch: the postmodern world of Dubravka Ugrešić', Slovo: Journal of East European, Russian and Eurasian Studies, 9:1.

Hawkesworth, C. (1996) 'The palindrome scandal and the Yugoslav War', in R. B. Pynsent (ed.), The Literature of Nationalism, London: Macmillan.

Hay, R. (1998) 'Croatia: community, conflict and culture: the role of soccer clubs in migrant identity', in M. Cronin and D. Mayall (eds), Sporting Nationalisms: Identity, Ethnicity, Immigration and Assimilation, London: Frank Cass.

Hayden, R. M. (1992) 'Constitutional nationalism in the former Yugoslav republics', Slavic Review, 51:4.

Hayden, R. M. (1992) 'Balancing discussion of Jasenovac and the manipulation of history', East European Politics and Societies, 6:4.

Hefer, S. (1956) Croatian Struggle for Freedom and Statehood, Buenos Aires: Croatian Information Service.

Heppell, M. and Singleton, F. B. (1961) Yugoslavia, London: Ernest Bell Ltd.

Hobden, S. and J. M. Hobson (eds) (2002) Historical Sociology of International Relations, Cambridge: Cambridge University Press.

Hobsbawm, E. (1969) 'The limits of nationalism', New Society, 2 October.

Hobsbawm, E. (1972) 'Some reflections on nationalism', in T. J. Nossiter, A. H. Hanson and S. Rokkan (eds), Imagination and Precision in the Social Sciences, London: Faber and Faber.

Hobsbawm, E. (1975) The Age of Capital: 1848-1875, London: Weidenfeld and Nicolson.

Hobsbawm, E. (1987) The Age of Empire: 1875-1914, London: Weidenfeld and Nicolson.

Hobsbawm, E. (1990) Nations and Nationalism since 1780: Programme, Myth, Reality, Cambridge: Cambridge University Press.

Hobsbawm, E. and Ranger, T. (eds) (1983) The Invention of Tradition, Cambridge: Cambridge University Press.

Hodge, C. C. (1998) 'Botching the Balkans: German recognition of Slovenia and Croatia', Ethics and International Affairs, 12.

Hoffman, G. W. (1963) The Balkans in Transition, London: Van Nostrand Co.

Hoffman, G. W. and Warner Neal, F. (1962) Yugoslavia and the New Communism, New York, Twentieth Century Fund.

Holbrooke, R. (1998) To End a War, revised edition, New York: Random House.

Holt, R., Mangen, J. A. and Lanfranch, P. (eds) (1996) European Heroes: Myth, Identity, Sport, London: Frank Cass.

Hopken, W. (1997) 'History education and Yugoslav (dis-)integration', in M. K. Bokovoy, J. A. Irvine and C. S. Lilly (eds), State-Society Relations in Yugoslavia, London: Macmillan.

Horvat, B. (1983) Self Governing Socialism, New York: International Arts and Sciences Press. Hroch, M. (1985) Social Preconditions of National Revival in Europe, Cambridge: Cambridge University Press.

Hroch, M. (1993) 'From national movement to fully formed nation', New Left Review, 198. Hrvatske Narodna Banka (HNB) (1997) Banks at the Crossroads: A Report on the Banking System in the Republic of Croatia, Zagreb: HNB Survey No. 4.

Hrvatske Narodna Banka (HNB) (1999) Annual Report 1998, Zagreb: HNB.

Hughson, J. (1997) 'Football, folk dancing and fascism: diversity and difference in multicultural Australia', Australian and New Zealand Journal of Sociology, 33.

Hutchinson, J. (1994) Modern Nationalism, London: Fontana. 
Hutchinson, J. and Smith, A. D. (eds) (1994) Nationalism, Oxford: Oxford University Press.

Ignatieff, M. (1994) Blood and Belonging: Journeys into the New Nationalism, London: Vintage.

Ignatieff, M. (1999) The Warrior's Honor: Ethnic War and the Modern Conscience, London: Vintage.

Inglis, F. (1977) The Name of the Game: Sport and Society, London: Heinemann.

International Crisis Group (1998) Change in the Offing: The Shifting Political Scene in Croatia, Brussels: International Crisis Group.

International Monetary Fund (IMF) (1997) Croatia - Selected Issues and Statistical Appendix, Washington DC: IMF Report No. 97/35.

Irvine, J. A. (1991) 'Tito, Hebrang and the Croat question 1943-1944', East European Politics and Societies, 5:2.

Irvine, J. A. (1992) The Croat Question: Partisan Politics in the Formation of the Yugoslav Socialist State, Boulder: Westview.

Ivić, P. (1986) The Serbian People and their Language, Belgrade: Srpska Knjizevna Zadruga. Jalušić, V. (1999) 'Women in post-socialist Slovenia: socially adapted, politically marginalized', in S. Ramet (ed.), Gender Politics in the Western Balkans, Pennsylvania: University of Pennsylvania Press.

Jambrešić, R. (1995) 'Testimonial discourse between national narrative and ethnography as socio-cultural analysis', Collegium Anthropologicum, 19.

James, A. (1993) 'The UN in Croatia: an exercise in futility?', World Today, 48:11.

James, P. (1997) Nation Formation: Towards a Theory of Abstract Community, London: Sage.

Janković, B. M. (1988) The Balkans in International Relations, London: Macmillan.

Jareb, J. (1984) 'Croatian language: from the eleventh century to the computer age', Journal of Croatian Studies, 25-6.

Javorović, B. (1996) 'Causes and goals of Serbian aggression against Croatia', in I. Živković (ed.), The Wounded Church in Croatia: The Destruction of the Sacral Heritage of Croatia (1991-1995), Zagreb: Croatian Heritage Foundation and the Croatian Conference of Bishops.

Jayawardena, J. (1986) Feminism and Nationalism in the Third World, London: Zed Books.

Jelavich, B. (1983) History of the Balkans: Eighteenth and Nineteenth Centuries, volume I, Cambridge: Cambridge University Press.

Jelavich, C. (1989) 'Nationalism as reflected in the textbooks of the South Slavs in the nineteenth century', Canadian Review of Nationalism, 16:1-2.

Jelavich, C. (1990) South Slav Nationalisms: Textbooks and Yugoslav Union Before 1914, Columbus Ohio: Ohio State University Press.

Jelavich, C. (1994) 'Education, textbooks and South Slav nationalism in the interwar era', in N. Reiter and H. Sundhaussen (eds), Allgemeinbildung als Modernisierungsfaktor: Zur Geschichte der Elementarbildung in Sundeosteuropa von der Aufklärung bis zum Zweiten Weltkreig, Berlin: Harrassowitz.

Johnson, N. (1995) 'Cast in stone: monuments, geography and nationalism, Environment and Planning D: Society and Space, 13.

Jolly, A. and Kattaneh, N. (eds) (1998) Doing Business in Croatia, London: Confederation of British Industry. 
Jović, D. (1992) 'Regional political parties’, Društvena Istraživanja, 1:1.

Jurković, P. and Škreb, M. (1994) 'Financial Reforms in Croatia', Hrvatske Narodna Banka Working Papers No. 1.1, Zagreb: Hrvatske Narodna Banka.

Kadić, A. (1979) 'Istria in Croatian literature', Journal of Croatian Studies, 20.

Kadić, A. (1980) 'The role of Vlado Gotovac in the Croatian democratic movement', Journal of Croatian Studies, 21.

Kaldor, M. (1999) New and Old Wars: Organized Violence in a Global Era., Cambridge: Polity.

Kale, E. (1999) Hrvatski Kulturni i Politički Identitet, Zagreb: Pan Liber.

Kandiyoti, D. (1991) 'National identity and its discontents: women and the nation', Millennium: Journal of International Studies, 20:3.

Kann, R. A. (1950) The Multinational Empire: Nationalism and National Reform in the Habsburg Monarchy 1848-1918, New York: Columbia University Press.

Kaplan, R. D. (1991) 'Balkan dilemmas', The New Republic, 196.

Kaplan, R. D. (1994) Balkan Ghosts: A Journey Through History, New York: Vintage.

Karahasen, D. (1993) Sarajevo: Exodus of a City, London: Kodansha International.

Kasapović, M. (1992) 'The political environment', in J. Seroka and V. Pavlović (eds), The Tragedy of Yugoslavia: The Failure of Democratic Transition, London: M. E. Sharpe. Katich, B. (ed.) (1983) So Speak Croatian Dissidents, Toronto: Ziral.

Katunarić, V. (ed.) (1997) Multicultural Reality and Perspectives in Croatia, Zagreb: Interkultura.

Katunarić, V. (1999) “"Real” and other compatriots: politics of identity in Croatia', in H. Kriesi, K. Armingeon, H. Siegrist and A. Wimmer (eds), Nation and National Identity: The European Experience in Perspective, Zurich: Verlag Ruegger.

Kearns, I. (1996) 'Croatian politics: the new authoritarianism', Political Quarterly, 67:1.

Kearns, I. (1997) 'Croatian democracy or authoritarianism?', paper presented to the Political Studies Association Conference on Eastern Europe.

Kedourie, E. (1993) Nationalism, 4th edition, Oxford: Blackwell.

Kellas, J. G. (1991) The Politics of Nationalism and Ethnicity, London: Macmillan.

Kerrigan, J. and Novick, W. (1998) Healing the Heart of Croatia, New York: Paulist Press.

Kesić, O. (1999) 'Women and gender imagery in Bosnia: amazons, sluts, victims, witches and wombs', in S. Ramet (ed.), Gender Politics in the Western Balkans, Pennsylvania: University of Pennsylvania Press.

Kiš, D. (1994) 'A man with no country', in J. Labon (ed.), Storm: Out of Yugoslavia, London: Storm.

Klemenčić, M. (ed.) (1993) A Concise Atlas of the Republic of Croatia and the Republic of Bosnia-Hercegovina, Zagreb: Miroslav Krleža Lexicographic Institute.

Klemenčić, M. (1995) 'Administrative-territorial division of Croatia', Geojournal, 35:4.

Klemenčić, M., Kušar, V. and Richter, Ž. (1993) 'Changes in the ethnical [sic] structure of Istria: census and spatial analyses 1880-1991’, Društvena Istraživanja, 6-7:2.

Kljakić, S. (1991) A Conspiracy of Silence: Genocide in the NDH and the Concentration Camp Jasenovac, Belgrade: Ministry of Information of the Republic of Serbia.

Knezević, A. (1996) An Analysis of Serb Propaganda, Zagreb: Domavina TT.

Kovačević, B. (1991) 'A view on the proposals for the solution of the Serb question in Croatia', Gaudeamus, 4.

Kraft, E. and George, W. J. (1993) The Structure of the Banking System in Croatia, Zagreb: Hrvatske Narodna Banka Survey No. 3. 
Krekić, B. (1972) Dubrovnik in the Fourteenth and Fifteenth Centuries: A City Between East and West, Norman OKL: University of Oklahoma Press.

Krekić, B. (1997) Dubrovnik: A Mediterranean Urban Society 1300-1600, London: Variorum.

Kricković, A. (1999) 'Football is war', Transitions, 6:3.

Kristo, J. (1995) 'The Catholic Church in a time of crisis', in S. P. Ramet and L. S. Adamovich (eds), Beyond Yugoslavia: Politics, Economics and Culture in a Shattered Community, Boulder: Westview.

Krleža, M. (1987) On the Edge of Reason, trans. Z. Depolo, London: Quartet Encounters.

Krleža, M. (1989) The Return of Philip Latinowicz, trans. Z. Depolo, London: Quartet Encounters.

Kuper, S. (1996) Football Against the Enemy, London: Phoenix.

Kuzmanović, J. (1995) 'Media: the extension of politics by other means', in S. P. Ramet and L. S. Adamovich (eds), Beyond Yugoslavia: Politics, Economics and Culture in a Shattered Community, Boulder: Westview.

Kuzmanović, T. Z. (1991) 'Croatia's constitution: a blueprint for democracy in Croatia', Journal of Croatian Studies, 32-3.

Labon, J. (ed.) (1994) Storm: Out of Yugoslavia, London: Storm.

Lampe, J. R. (1996) Yugoslavia as History: Twice There Was a Country, Cambridge: Cambridge University Press.

Layder, D. (1994) Understanding Social Theory, London: Sage.

Lederer, I. J. (1963) Yugoslavia at the Paris Peace Conference, London: Yale University Press.

Lee, S. J. (1987) The European Dictatorships: 1918-1945, London: Methuen.

Lerner, A. J. (1991) 'Introduction to reimagining the nation', Millennium: Journal of International Studies, 20:3.

Lloyd, C. (1994) The Structures of History, Oxford: Basil Blackwell.

Longworth, P. (1979) 'The Senj Uskoks reconsidered', Slavonic and East European Review, 57:3.

Lovrich, F. (1966) 'Croatians in Louisiana', Journal of Croatian Studies, 7-8.

Lučić, Z. (1998) 'On the constitutional organization of the Republic of Croatia', in D. Brunčić, Z. Lučić, V. Ljubanović and I. Vrjkić (eds), Legal System of the Republic of Croatia, Osijek: Collegium-University of Osijek.

Luk, A. N. (1995) 'The linguistic aspect of ethnic conflict in Yugoslavia', in P. Akhavan and R. Howse (eds), Yugoslavia: The Former and Future, Washington DC: The Brookings Institute.

Macan, T. (1992) A Short History of Croatia, Zagreb: Most/The Bridge.

Maccartney, C. A. (1934) Hungary, London: Ernest Benn Ltd.

Maccartney, C. A. (1937) Hungary and her Successors, Oxford: Oxford University Press.

Maccartney, C. A. (1962) Hungary: A Short History, Edinburgh: Edinburgh University Press

Maček, V. (1957) In the Struggle for Freedom, trans. E. Gazi and S. Gazi, London: Pennsylvania State University Press.

MacDonald, G. C. (1973) Area Handbook for Yugoslavia, 1st edition, Washington DC: US Government Printing.

Maclaughlin, A. (1992) 'Review article', Journal of Multilingual and Multicultural Development, 11:6. 
Maclean, F. (1980) Josip Brož Tito: A Pictorial Biography, Maidenhead: McGraw-Hill. Magaš, B. (1993) 'The aftermath of the Pope's visit in 1994', The Tablet, 17 July.

Magaš, B. (1993) The Destruction of Yugoslavia: Tracking the Break-up: 1980-92, London: Verso.

Malcolm, N. (1994) Bosnia: A Short History, London: Papermac.

Malcolm, N. (1997) 'My country, old or new?', Sunday Telegraph, 30 November.

Malcolm, N. (1998) Kosovo: A Short History, London: Macmillan.

Malesević, S. (1996) 'Utopia and dystopia after communism: visions of an ideal society among Zagreb university students', East European Quarterly, 30:3.

Malkki, L. H. (1995) Purity and Exile: Violence, Memory and National Cosmology Among Hutu Refugees in Tanzania, London: University of Chicago Press.

Malović, S. and Selnow, G. W. (2001) The People, Press and Politics of Croatia, Westport: Praeger.

Mangen, J. A. (ed.) (1996) Tribal Identities: Nationalism, Europe, Sport, London: Frank Cass.

Markotić, V. (1970) 'Archaeology', in F. Eterovich and C. Spalatin (eds), Croatia: Land, People, Culture, volume 1, Toronto: University of Toronto Press.

Markotich, S. (1993) 'Istria seeks autonomy', Radio Free Europe Research Report, 10 September.

Markovich, S. (1998) 'Democracy in Croatia: views from the opposition', East European Quarterly, 32:1.

Mateša, S. and Brekalo, F. (1992) The Country Privatization Report - 1992: Croatia, Zagreb: Agency for Reconstruction and Development.

Matijašić, R. (1993) 'The early history of Istria and some reflections on modern times', Društvena Istraživanja, 6-7:2.

McCrone, D. (1998) The Sociology of Nationalism, London: Routledge.

Mertus, J. (1999) Kosovo: How Myths and Truths Started a War, Los Angeles: University of California Press.

Ministry of Development and Reconstruction (1996) National Demographic Development Programme, Zagreb: Government of the Republic of Croatia.

Ministry of Development and Reconstruction (1997) Handbook of the Ministry of Development and Reconstruction, Zagreb: Ministry of Development and Reconstruction.

Ministry of Education and Sports (1997) Starting Points for Strategy of Long-Term Development of Education in the Republic of Croatia, Zagreb: Ministry of Education and Sports.

Ministry of Education and Sports (1999) The Development of Education: The National Report, Zagreb: Ministry of Education and Sports.

Mojzes, P. (1986) 'Religious liberty in Yugoslavia: a study in ambiguity', in L. Swidler (ed.), Religious Liberty and Human Rights in Nations and in Religions, Philadelphia: Ecumenical Press.

Mojzes, P. (1993) 'The Roman Catholic Church in Croatia and its contribution to nationalist sentiment', Religion, State and Society, 21:3-4.

Mojzes, P. (1994) Yugoslavian Inferno: Ethnoreligious Warfare in the Balkans, New York: Continuum.

Mojzes, P. (1997) 'The role of religious communities in the development of civil society in Yugoslavia, 1945-1992', in M. K. Bokovoy, J. A. Irvine and C. S. Lilly (eds), StateSociety Relations in Yugoslavia, London: Macmillan. 
Murphy, A. B. (1993) 'Linguistic regionalism and the social construction of space in Belgium', International Journal of the Sociology of Language, 104.

Murray-Despalatović, E. (1975) Ljudevit Gaj and the Illyrian Movement, London: C. Hurst and Co.

Murvar, V. (1955) 'The Croat statehood and its continuity', in A. F. Bonifačić and C. S. Mihanovich (eds), The Croatian Nation in its Struggle for Freedom and Independence, Chicago: Cultural Publishing Centre.

Nairn, T. (1981) The Break-up of Britain: Crisis and Neo-Nationalism, 2nd edition, London: Verso.

Nairn, T. (1988) The Enchanted Glass: Britain and its Monarchy, London: Radius.

Nairn, T. (1997) Faces of Nationalism: Janus Revisited, London: Verso.

National Committee for Human Rights Education (1999) National Program of Human Rights Education, Zagreb: Government of the Republic of Croatia Documents.

Nimni, E. (1991) Marxism and Nationalism: Theoretical Origins of a Political Crisis, London: Pluto Press.

Norton, A. (1994) International Handbook of Local and Regional Government: A Comparative Analysis of Advanced Democracies, London: Edward Elgar.

Omrčanin, I. (1972) Diplomatic and Political History of Croatia, Philadelphia: Dorrance.

Omrčanin, I. (1976) Sacred Crown of the Kingdom of Croatia, Philadelphia: Dorrance.

Omrčanin, I. (1984) Military History of Croatia, Philadelphia: Dorrance.

Omrčanin, I. (1986) Holocaust of Croatians, Washington: Samizdat.

Open Society Institute (OSI) (1996) Community Spirit in Action, Zagreb: OSI.

Open Society Institute (OSI) (1999) Open Society Institute - Croatia, Zagreb: OSI.

Organization for Security and Co-operation in Europe (OSCE) (1997) The 1997 Parliamentary County and Municipal Elections in Croatia, London: OSCE.

Organization for Security and Co-operation in Europe (OSCE) (1998) Special Report on Education, Zagreb: OSCE (Croatia).

Organization for Security and Co-operation in Europe (OSCE) (1999) Educational Rights of Minorities in International Law, Zagreb: OSCE (Croatia).

Ostrogorsky, G. (1956) History of the Byzantine Empire, trans. J. Husse, Oxford: Basil Blackwell.

Owen, D. (1996) Balkan Odyssey, London: Indigo.

Palmieri, A. R. (1919) 'Growth of Croatian nationalism', Catholic World, 109.

Papastergiadis, N. (1991) 'Reading dissemination', Millennium: Journal of International Studies, 20:3.

Parekh, B. (1998) 'Review of Paul James "Nation Formation"', Nations and Nationalism, $4: 2$.

Paris, E. (1981) Genocide in Satellite Croatia: A Record of Racial and Religious Persecutions and Massacres, Melbourne: Srpska Misao.

Pavlović, D. M. (1998) Croats in Chile: Biographics, Zagreb: Nacionalna i Sveučilišna Knjižnica.

Pavlović, T. (1999) 'Women in Croatia: feminists, nationalists and homosexuals', in S. Ramet (ed.), Gender Politics in the Western Balkans, Pennsylvania: University of Pennsylvania Press.

Pavlowitch, S. K. (1989) The Improbable Survivor: Yugoslavia and its Problems 19181988, Columbus: Ohio State University Press.

Pavlowitch, S. K. (1992) Tito: A Reassessment, London: C. Hurst and Co. 
Perić, I. (1989) Povijest 2: Udžbenik za Usmjereno Obrazovanje, Zagreb: Skolska Knjiga.

Perić, I. (1996) Povijest za VIII, Zagreb: Razred Osnovne Škole.

Perić, I. (1999) A History of the Croats, Zagreb: CTT.

Periwal, S. (ed.) (1995) Notions of Nationalism, Budapest: Central European University Press.

Petrić, P. (1993) 'Istrian graduates on marriage and sexual life', Društvena Istraživanja, 6-7:2.

Petrović, R. (1991) The Extermination of the Serbs on the Territory of Croatia, Belgrade: Ministry of Information of the Republic of Serbia.

Pleština, D. (1993) 'Politics, economics and war: problems of transition in contemporary Croatia', Center for German and European Studies Working Paper 5.15, Berkeley: University of California.

Pleština, D. (1995) 'Democracy and nationalism in Croatia: the first three years', in S. P. Ramet and L. S. Adamovich (eds), Beyond Yugoslavia: Politics, Economics and Culture in a Shattered Community, Boulder: Westview.

Polley, M. (1995) Moving the Goalposts: A History of Sport and Society Since 1945, London: Routledge.

Portal, R. (1969) The Slavs, London: Weidenfield and Nicolson.

Porter, D. (1983) 'New observations on Ivan Mestrović', Journal of Croatian Studies, 24.

Powers, G. F. (1996) 'Religion, conflict and prospects for reconciliation in Bosnia, Croatia and Yugoslavia', Journal of International Affairs, 50:1.

Pozzi, H. (1994) The Black Hand Over Europe, reprint of the 1935 edition, Zagreb: Croatian Information Centre.

Preston, P. (1997) Political/Cultural Identity: Citizens and Nations in a Global Era, London: Sage.

Preveden, F. R. (1955) A History of the People of Croatia, volume 1, New York: Philosophical Library.

Preveden, F. R. (1962) A History of the Croatian People, volume 2, New York: Philosophical Library.

Previšić, V. (1997) 'Croatian schools facing the challenge of multiculturalism' in V. Katunarić (ed.), Multicultural Reality and Perspectives in Croatia, Zagreb: Interkultura.

Prnjak, H. (1997) Bad Blue Boys - Prvih Deset Godina: Dru Tveni Fenomen Navijaxa Nogometnog Kluba Dinamo, Zagreb: Marjan Express.

Puhovski, V. (1999) Croatia: Community Spirit in Action Education 2000, Zagreb: OSI.

Pusić, V. (1993) 'Dictatorships with democratic legitimacy', Erasmus, 1:1.

Pusić, V. (1994) 'Dictatorships with democratic legitimacy: democracy versus nation', East European Politics and Societies, 8:4.

Puvačić, D. (1996) 'Tin Ujević and the Yugoslav ideal', in R. B. Pynsent (ed.), The Literature of Nationalism, London: Macmillan.

Račan, I. (1998) 'Sketches of Croatia: transition inside transition', European Forum Newsletter, 19.

Radcliffe, S. and Westwood, S. (1996) Remaking the Nation: Place, Identity and Politics in Latin America, London: Routledge.

Ramet, P. (1982) 'Catholicism and politics in socialist Yugoslavia', Religion in Communist Lands, 10:3.

Ramet, P. (1985) 'Factionalism in church-state interaction: the Croatian Catholic Church in the 1980', Slavic Review, 44:2. 
Ramet, P. (1989) 'Religion and nationalism in Yugoslavia', in P. Ramet (ed.), Religion and Nationalism in Soviet and East European Politics, Durham NC: Duke University Press.

Ramet, S. (1996) Balkan Babel: The Disintegration of Yugoslavia from the Death of Tito to Ethnic War, 2nd edition, Boulder: Westview.

Ramet, S. (1996) 'The Croatian Catholic Church since 1990', Religion, State and Society, 24:4.

Ramet, S. (ed.) (1999) Gender Politics in the Western Balkans, Pennsylvania: University of Pennsylvania Press.

Ramet, S. and Adamovich, L. S. (eds) (1995) Beyond Yugoslavia: Politics, Economics and Culture in a Shattered Community, Boulder: Westview.

Raynes, R. (1995) 27 Kisses: The Last Coach From Croatia, Omskirk Lancs: Thomas Lyster.

Rehn, E. (1997) 'Report on the situation of human rights in the Republic of Croatia', United Nations Economic and Social Council, E/CN.4/1998/14.

Renan, E. (1882) Qu'est-ce qu'une Nation?, Paris: Calmann-Levy.

Republic of Croatia Central Bureau of Statistics (1999) Statistical Information 1998, Zagreb: Central Bureau of Statistics.

Rieff, D. (1995) Slaughterhouse: Bosnia and the Failure of the West, London: Vintage.

Riordan, J. (1977) Sport in Soviet Society, Cambridge: Cambridge University Press.

Ristić, D. (1960) Yugoslavia's Revolution of 1941, London: Pennsylvania State University Press.

Roberts, W. H. (1973) Tito, Mihailović and the Allies: 1941-45, New Jersey: Rugters University Press.

Rogić, V. (1978) 'Contribution to the problems of regionalization in Yugoslavia', Geographical Papers, 4:1-2.

Rohatinski, Ž. (1993) 'Ekonomske situacija na pocetku 1993 godine', in Z. Rohatinski and D. Vojnić (eds), Aktualni Problemi Privrednih Kretanja i Ekonomske Politike Hrvatske, Zagreb: Ekonomski Institut.

Rohatinski, Ž. (1996) 'New challenges', in Croatian Economic Survey 1995, Zagreb: Ekonomski Institut and Hrvatske Narodna Banka.

Rothenberg, G. E. (1964) 'The Croatian military border and the rise of Yugoslav nationalism', Slavonic and East European Review, 43:1.

Rothenberg, G. E. (1966) The Military Border in Croatia: A Study of an Imperial Institution, London: University of Chicago Press.

Runciman, W. G. (ed.) (1978) Weber. Selections in Translation, trans. E. Matthews, Cambridge: Cambridge University Press.

Rusinow, D. (1977) The Yugoslav Experiment: 1948-1974, London: C. Hurst and Co. for the Royal Institute of International Affairs.

Sabalić, I. (1994) 'Authoritarianism in Croatia and prospects for change', New Politics, 1.

Salay, C. (1995) Election Observation Report of the Elections to the House of Representatives: Republic of Croatia, Washington DC: International Foundation for Election Systems.

Schevill, F. (1991) A History of the Balkans From the Earliest Times to the Present Day, New York: Dorset Press.

Schonfelder, B. (1993) 'Croatia: between reform and post-communist populism', Communist Economies and Economic Transformation, 5:3. 
Sells, M. A. (1998) The Bridge Betrayed: Religion and Genocide in Bosnia, revised edition, London: University of California Press.

Serbian Academy of Arts and Sciences (SANU) (1991) Some Basic Facts About the Position of Serbian People in Croatia, Belgrade: SANU.

Seroka, J. and Pavlović, V. (eds) (1992) The Tragedy of Yugoslavia: The Failure of Democratic Transition, London: M. E. Sharpe.

Seton-Watson, H. (1946) Eastern Europe Between the Wars 1918-1941, Cambridge: Cambridge University Press.

Seton-Watson, H. (ed.) (1976) R. W. Seton-Watson and the Yugoslavs: Correspondence 1906-1941, 2 volumes, London: British Academy.

Seton-Watson, R. W. (1911) The Southern Slav Question, London: G. Bell and Sons.

Seton-Watson, R. W. and Laffan, R. G. D. (1968) 'Yugoslavia between the wars', in H. C. Darby and R. W. Seton-Watson, A Short History of Yugoslavia from Early Times to 1966, Cambridge: Cambridge University Press.

Shaw, L. (1973) Trial by Slander, Canberra: Harp Books.

Shils, E. (1957) 'Primordial, personal, sacred and civil ties', British Journal of Sociology, 8.

Siber, I. (1992) 'The impact of nationalism, values and ideological orientations in multiparty elections in Croatia', in J. Seroka and V. Pavlović (eds), The Tragedy of Yugoslavia: The Failure of Democratic Transition, London: M. E. Sharpe.

Siber, I. (ed.) (1997) The 1990/93 Sabor Elections in Croatia: Analysis, Documents and Data, Berlin: Edition Sigma.

Silber, L. and Little, A. (1995) The Death of Yugoslavia, London: Penguin.

Smith, A. D. (1971) Theories of Nationalism, London: Duckworth.

Smith, A. D. (1981) The Ethnic Revival in the Modern World, Cambridge: Cambridge University Press.

Smith, A. D. (1983) 'Nationalism and classical social theory', British Journal of Sociology, $34: 1$.

Smith, A. D. (1989) 'The origins of nations', Ethnic and Racial Studies, 12:3.

Smith, A. D. (1991) 'The nation: invented, imagined, reconstructed?', Millennium: Journal of International Studies, 20:3.

Smith, A. D. (1991) National Identity, Harmondsworth: Penguin.

Smith, A. D. (1992) 'Nationalism and the historians', in A. D. Smith (ed.), Ethnicity and Nationalism: International Studies in Sociology and Social Anthropology, Leiden: Brill.

Smith, A. D. (1995) 'National identities: modern and medieval?', in S. Forde, L. Johnson and A. V. Murray (eds), Concepts of National Identity in the Middle Ages, Leeds: Leeds Texts and Monographs.

Smith, A. D. (1996) 'Opening statement: nations and their pasts', Nations and Nationalism, 2:3.

Smith, A. D. (1996) 'Memory and modernity: reflections on Ernest Gellner's theory of nationalism', Nations and Nationalism, 2:3.

Smith, A. D. (1998) Nationalism and Modernism, London: Routledge.

Smith, A. D. (1999) 'Ethnic election and national identity: some religious origins of nationalist ideals', Nations and Nationalism, 5:3.

Sosić, H. (1993) Croatian Political Dictionary, Rijeka: Tiskara Rijeka.

Spalatin, C. (1966-67) 'Serbo-Croatian or Serbian and Croatian? Considerations on the Croatian declaration and Serbian proposal of March 1967', Journal of Croatian Studies, 7-8. 
Spalatin, C. (1973-74) 'The language situation in Croatia today', Journal of Croatian Studies, 14-15.

Spalatin, C. (1974-75) 'The Croatian language today', Journal of Croatian Studies, 15-16.

Spalatin, C. (1975) 'The rise of the Croatian standard language', Journal of Croatian Studies, 16.

Spalatin, C. (1984-85) 'A survey of the linguistic periodical Jezik', Journal of Croatian Studies, 25-6.

Stanković, S. (1981) The End of the Tito Era: Yugoslavia's Dilemmas, Stanford: Hoover Institute Press.

State Institute for the Protection of Family, Maternity and Youth (1998) Youth in the Republic of Croatia, Zagreb: State Institute for the Protection of Family, Maternity and Youth.

State Institute for the Protection of Family, Maternity and Youth (1999) Children in the Republic of Croatia, Zagreb: State Institute for the Protection of Family, Maternity and Youth.

Steinberg, J. (1994) 'Types of genocide? Croatians, Serbs and Jews: 1941-5', in D. Ceserani (ed.), The Final Solution: Origins and Implementation, London: Routledge.

Stewart, B. (1993) Broken Lives: A Personal View of the Bosnian Conflict, London: Harper Collins.

Stiglmayer, A. (ed.) (1993) Mass Rape: The War Against Women in Bosnia-Hercegovina, London: Pinter.

Stubbs, P. (1997) 'Social reconstruction and social development in Croatia and Slovenia: the role of the NGO sector', International Social Policy Research Unit Occasional Paper No. 7, Leeds; University of Leeds.

Sučić, D. S. (1996) 'The fragmentation of Serbo-Croatian into three new languages', Transition, 24:2.

Suran, F. (1993) 'Istrianity as the weaker (or stronger) identity', Društvena Istraživanja, $6-7: 2$.

Šetić, N. (1993) 'The beginnings of the modern Croatian nation in Istria - a draught [sic] for future research', Društvena Istraživanja, 6-7:2.

Šimunović, I. (1993) 'The regional concept of development in Croatia', Društvena Istraživanja, 6-7:2.

Škiljan, D. (1992) 'Standard languages in Yugoslavia', in R. Bugarski and C. Hawkesworth (eds), Language Planning in Yugoslavia, Columbus Ohio: Slavica.

Škiljan, D. (1994) Processes of Ideolization in Language, Zagreb: Centre for Transition and Civil Society Research.

Škreb, M. (1995) 'Monetary independence as a precondition for macroeconomic stability - the case of Croatia', Development and International Cooperation, 11:20-1.

Škreb, M. (1998) 'Economic transition in Croatia: an insiders view', Journal of Democracy, 17:2.

Šuljak, D. N. (1977) Croatia's Struggle for Independence: A Documentary History, Arcadia California: Croatian Information Service.

Takei, M. (1998) 'Collective memory as the key to national and ethnic identity: the case of Cambodia', Nationalism and Ethnic Politics, 4:3.

Tanner, M. (1997) Croatia: A Nation Forged in War, London: Yale University Press.

Taras, R. (1998) 'Nations and language building: old theories, contemporary cases', Nationalism and Ethnic Politics, 4:3. 
Thomas, G. (1988) The Impact of the Illyrian movement on the Croatian Lexicon, Munich: O. Sagner.

Thompson, M. (1992) A Paper House: The Ending of Yugoslavia, London: Vintage.

Thompson, M. (1994) Forging War: The Media in Serbia, Croatia and Bosnia-Herzegovina, London: Vintage.

Tindemanns, L., Sommer, T. Veil, S. and Anderson, D. (1996) Unfinished Peace: Report of the International Commission on the Balkans, Washington DC: Aspen Institute Berlin/Carnegie Endowment for International Peace.

Todorova, M. (1997) Imagining the Balkans, Oxford: Oxford University Press.

Tolj, I., Bičanić, N., and Mujčić, K. (1992) For Croatia, Zagreb: Croatian Ministry of Defence.

Tomac, Z. (1993) The Struggle for the Croatian State, Zagreb: Profikon.

Trifković, S. (1992) 'The first Yugoslavia and origins of Croatian separatism', East European Quarterly, 26:3.

Trifković, S. (1993) 'Yugoslavia in crisis: Europe and the Croat question, 1939-41', European History Quarterly, 23.

Trogančić, F. (1970) 'Literature 1400-1835', in F. Eterovich and C. Spalatin (eds), Croatia: Land, People, Culture, volume 1, Toronto: University of Toronto Press.

Tuðman, F. (1981) Croatia on Trial, London: United Publishers.

Tuðman, F. (1981) Nationalism in Contemporary Europe, New York: Columbia University Press.

Tuðman, F. (1983) 'The reply to the indictment at the trial at the district court in Zagreb on 17 February, 1981', in B. Katich (ed.), So Speak Croatian Dissidents, Toronto: Ziral.

Tuðman, F. (1991) Croatia at the Crossroads: In Search of a Democratic Confederacy, London: Centre for Policy Studies.

Tuðman, F. (1997) Horrors of War: Historical Reality and Philosophy, revised edition, trans. K. Mijatović, New York: M. Evans and Co.

Udovički, J. (1997) 'The bonds and the faultlines', in J. Udovički and J. Ridgeway (eds), Burn this House: The Making and Unmaking of Yugoslavia, London: Duke University Press.

Udovički, J. and Ridgeway, J. (eds) (1997) Burn this House: The Making and Unmaking of Yugoslavia, London: Duke University Press.

Ugrešić, D. (1993) In the Jaws of Life and Other Stories: Writings from an Unbound Europe, trans. M. Henry and C. Hawkesworth, Evanston ILL: Northwestern University Press.

Ugrešić, D. (1996) 'The confiscation of memory', New Left Review, 218.

Ugrešić, D. (1997) The Museum of Unconditional Surrender, trans. C. Hawkesworth, London: Phoenix House.

Ugrešić, D. (1998) The Culture of Lies: Antipolitical Essays, trans. C. Hawkesworth, London: Pheonix House.

Ulam, A. B. (1952) Titoism and the Cominform, Westport: Greenwood Press.

Uzelac, G. (1998) 'Franjo Tudjman's [ sic] nationalist ideology', East European Quarterly, 31:3.

Van den Berghe, P. (1978) 'Race and ethnicity: A sociobiological perspective', Ethnic and Racial Studies, 1:4.

Van den Berghe, P. (1979) The Ethnic Phenomenon, New York: Elsevier. 
Van den Berghe, P. (1988) 'Ethnicity and the sociobiology debate', in J. Rex and D. Mason (eds), Theories of Ethnic and Race Relations, Cambridge: Cambridge University Press.

Van den Berghe, P. (1995) 'Does race matter?', Nations and Nationalism, 1:3.

Vanek, J. (1981) Self-Management: Economic Liberation of Man. Selected Readings, Harmondsworth: Penguin.

Vejvoda, I. (1996) 'From decentralization without democracy to dissolution', in D. A. Dyker and I. Vejvoda (eds), Yugoslavia and After: A Study in Fragmentation, Despair and Rebirth, London: Longman.

Verdery, K. (1995) 'Introduction', in I. Banac and K. Verdery (eds), National Character and National Ideology in Interwar Eastern Europe, New Haven: Yale Center for International and Area Studies.

Verdery, K. (1996) 'Whither "nation" and "nationalism"?', in G. Balakrishnan (ed.), Mapping the Nation, London: Verso.

Veselica, M. (1981) The Croatian National Question: Yugoslavia's Achilles Heel, London: United Publishers.

Veselica, M. (1983) 'The Croatian democratic movement 1966-71', in B. Katich (ed.), So Speak Croatian Dissidents, Toronto: Ziral.

Vickers, M. (1998) Between Serb and Albanian: A History of Kosovo, London: C. Hurst and Co.

Violich, F. (1997) The Bridge to Dalmatia: A Search for the Meaning of Place, Baltimore: Johns Hopkins University Press.

Vitez, V. (1970) History of the Croatian Coast, Melbourne: Richmond.

Vladovich, S. (1995) Croatia: The Making of a Nation, Oklahoma: Vladovich Publishing.

Vojnić, D. (1995) 'Economy and politics of transition: the road to the welfare state and economy', Croatian Economic Survey, Zagreb: Ekonomski Institut and Hrvatske Narodna Banka.

Vojnović, L. (1963) Dalmatia and the Yugoslav Movement, London: George Allen and Unwin.

Von Herder, J. G. (1968) Reflections on the Philosophy of the History of Mankind, London: University of Chicago Press.

Vrbanić, G. F. (1991) The Failure to Save the First Yugoslavia: The Serbo-Croat Sporazum of 1939, Chicago: Ziral.

Vrbošić, J. (1993) 'Historical survey of the development of the Županian government and autonomy in Croatia', Društvena Istraživanja, 1:1.

Vrcan, S. (1995) 'Religion and churches and the post-Yugoslav war', in J. Coleman and M. Tonka (eds), Religion and Nationalism, Maryknoll NY: Orbis.

Vujica, S. M. (1965) Croatia's Struggle for Independence, New York: Croatian National Council in Exile.

Walby, S. (1996) 'Women and nation', in G. Balakrishnan (ed.), Mapping the Nation, London: Verso.

Wallerstein, I. (1991) Geopolitics and Geoculture: Essays on the Changing World System, Cambridge: Cambridge University Press.

Weber, M. (1968) 'The nation', in H. H. Gerth and C. Wright-Mills (trans. and eds), From Max Weber: Essays in Sociology, Oxford: Oxford University Press.

Weber, M. (1978) Economy and Society, Berkeley: University of California Press.

Weber, M. (1980) 'The national state and economic policy', Economy and Society, 9:4. 
Wendt, A. (1987) 'The agent-structure problem in international relations theory', International Organization, 41:3.

Wendt, A. (1999) The Social Construction of Reality, Cambridge: Cambridge University Press.

West, R. (1982) Black Lamb and Grey Falcon: A Journey Through Yugoslavia, Papermac: London (1940).

Wheeler, M. C. (1980) Britain and the War for Yugoslavia 1940-43, New York: Columbia University Press.

Wheeler, M. C. (1988) 'White eagles and white guards: British perceptions of anticommunist insurgency in Yugoslavia in 1945', Slavonic and East European Review, 66.

Wilkes, J. J. (1969) History of the Provinces of the Roman Empire: Dalmatia, London: Routledge and Kegan Paul.

Williams, H. (1992) International Relations in Political Theory, Milton Keynes: Open University Press.

Winnifrith, T. J. (1987) The Vlachs: The History of a Balkan People, London: Duckworth and Co.

Wolff, K. (ed.) (1964) Emile Durkheim et al: Essays on Sociology and Philosophy, New York: Harper and Row.

Wolff, R. L. (1956) The Balkans in Our Time, Cambridge Mass: Harvard University Press.

Woodward, S. L. (1995) Balkan Tragedy: Chaos and Dissolution After the Cold War, Washington DC: The Brookings Institute.

Wozniak, F. E. (1981) 'Count Marcellinus and Dalmatian autonomy: a study in the continuity of the Roman tradition', in I. Banac, J. G. Ackerman and R. Szporluk (eds), Nation and Ideology: Essays in Honor of Wayne S. Vucinich, New York: Columbia University Press.

Yuval-Davis, N. (1997) Gender and Nation, London: Sage.

Yuval-Davis, N. and Anthias, F. (eds) (1989) Women - Nation - State, London: Sage.

Zakošek, N. (1993) The Croatian Parliament During the Period of Democratic Transition: Constitutional and Policy Aspects, Zagreb: University of Zagreb.

Zakošek, N. (1997) 'Political parties and the party system in Croatia', in I. Siber (ed.), The 1990/93 Sabor Elections in Croatia: Analysis, Documents and Data, Berlin: Edition Sigma.

Zarek, O. (1942) Kossuth, London: Selwyn and Blount.

Zimmermann, W. (1996) Origins of a Catastrophe: Yugoslavia and its Destroyers, New York: Times Books.

Zlatar, Z. (1992) Between the Double Eagle and the Crescent, New York: East European Monographs No. 348.

Žanić, I. (1995) 'The curse of King Zvonimir and political discourse in embattled Croatia', East European Politics and Societies, 9:1.

Žerjavić, V. (1993) 'Immigration and emigration from the Istria, Rijeka and Zadar areas in the period from 1910 to 1971', Društvena Istraživanja, 6-7:2.

Živković, I. (ed.) (1996) The Wounded Church in Croatia: The Destruction of the Sacral Heritage of Croatia (1991-1995), Zagreb: Croatian Heritage Foundation and the Croatian Conference of Bishops.

Živojinović, D. R. (1979) America, Italy and the Birth of Yugoslavia: 1917-1919, London: Columbia University Press.

Žuljić, S. (1994) Hrvatska Istra: Suvremene Narodnosne Prilike, Zagreb: Nakladni Zavod Globus. 


\section{$q_{\text {NDEX }}$}

Aleksander, King 47, 49

Alexander, S. 157

Anderson, B. 10, 13-15, 22, 23, 26, 65

Andrić, I. 152

Armstrong, J. 8

Avakumović, I. 51

Bad Blue Boys 113-14, 117-21, 128, 164, $165,175-8$

Bakovi , D. 160, 161

Banac, I. 5, 33, 45, 80-1, 94, 96, 171 as dissident intellectual $85-8,92$

historical statehood thesis 32-3, 177

Baranović, B. 148, 149, 151, 175

Beljan, J. 156

Bičanić, I. 107

Billig, M. 4, 20-3, 65

Bjelica, M. 52

Blazević, M. 113, 115-16

Bleiburg massacres 71, 148, 151

Boban, M. 93

Boban, Z. 114, 118

Bozanić, Archbishop 161, 162

Brass, P. 12, 13

Breuilly, J. 4, 10-13

Brozović, D. 139, 140, 143

Brubaker, R. 174

Budak, M. 52, 71, 84

Buden, B. 84

Budiaša, D. 76, 80-1, 129

Čkavian dialect 44, 145, 146 see also language politics

Čakavica 127, 145

Caldarović, O. 176

Campbell, D. 164, 171, 172

Chatterjee, P. 4

Connor, W. 8-10

Croatian diaspora 84, 92-7, 118
Investment Promotion Agency 109-11

League of Communists 55-6, 78

Minister of State 156

Ministry of Defence 66

Ministry of Development and

Reconstruction 106, 160

Ministry of Education and Sport 14851, 154, 155

Parliament see Sabor

Post and Telecommunications

Corporation (HTP) 106

'Spring' 55, 70, 76, 79, 81, 139

Croatian Academy of America 94-5

Croatian Bishops Conference 156

Croatian Democratic Union see HDZ

Croatian Party of Rights see HSP

Croatian Peasants Party see HSS

Croatian Population Movement 160, 161

Četniks 51-4, 86, 148, 150-1

Dabčević-Kučar, S. 55, 76

Dalmatia 33-6, 39, 41, 46-7, 50, 92, 117, $122,124,138,145,172,180$

Dayton peace conference/agreement 4, 72,111

Dedijer, V. 52-3

Denitch, B. 79

Despalatović, E. 37

Devlahovich, J. 109

Dinamo Zagreb 113-14, 117-21, 175

Djilas, M. 157

Drakulić, S. 5, 85, 88-92, 95-7, 112, 124-5

Drasković, J. 44

Držislav, S. 36

Dubrovčka Banka 107-8

Dubrovnik 3, 36, 40-1, 74, 87, 122, 124, $128,141,144-5,152,161$

economy, the national 105-12

education, politics of 143, 147-56, 177 
Ekmečić, V. 47

Emperley, H. 33

Eterovich, F. 171

Feral Tribune 66, 86, 127, 143, 145

Fisher, H. 48

football 112-21, 144

Franciscans 141, 159, 163

and Second World War 53

Franjoism 5, 52, 65-76, 78, 82-6, 88-97, $104,116,122,128,143,148,151-8$, $160,162-5,172,174-80,181-3$

Frankopan, K. 152

Fishman, J. 8

Gaj, L. 37, 44, 68, 87, 152, 173

Gazi, S. 33, 47, 49, 87, 94

Gellner, E. 147

Glagolitic 140

Glas Koncila 158, 162

Geertz, C. 4, 8

Gellner, E. 4, 7, 14-16, 25, 171, 173

Giddens, A. 12, 13, 25

Glenny, M. 171

Goss, V. 94

Gotovac, V. 76, 80-2, 94, 109

Greenberg, L. 140

Gross, M. 32, 45, 171

Guldescu, S. 39, 41, 87

Gundulić, I. 87, 152

Habsburg Empire 68

1526 incorporation of Croatia 38-40, 172

rule $40-7$

Hajduk Split 113, 117

Hall, S. 174

Hammel, E. 137

Hastings, A. 8, 11

Hawkesworth, C. 141

HDZ, Hrvatska Demokratska Zajednica

(Croatian Democratic Union) 1-6, $86,88,96,107-9,137,172,174-80$, 182

BiH 93

formation 56

rule in the 1990s 66-76, 80-5, 112, 143-50, 156, 158-65,
Hebrang, A. 70, 94

Herceg-Bosna 4, 77, 93

Herder, von O. 8

historical statehood thesis 33-5, 43, 45, 73-4, 84, 86-8, 92, 96

HNB (Hrvatska Narodna Banka) Croatian National Bank 105-7, 110-11

HNO (Hrvatski Narodni Otpor) Croatian National Resistance 93

HNS (Hrvatska Narodna Stranka) Croatian People's Party 76, 83, 128

HNS (Hrvatska Nogomet Savez) Croatian Football Federation 115

Hobsbawm, E. 13-16, 173, 182

Hoffman, G. 34

Hopken, W. 147, 149, 151

HOS (Hrvatske Obrambene Snage) Croatian Defence Force 78

Hroch, M. 16

Hrvatska Pravda (Croatia Justice) 94

Hrvatska Zena 160

Hrvatski Obzor 75

HSLS (Hrvatska Socijalno Liberalna Stranka) Croatian Social Liberal

Party 76, 80-2, 85, 109, 129

HSP (Hrvatska Stranka Prava) Croatian Party of Rights

in the 1990s 76-8, 82, 96

nineteenth century 45-6, 176

HSP-1861 77

HSS (Hrvatska Seljačka Stranka) Croatian

Peasants Party 46, 49-50, 53, 82-3, 84, 96, 109

see also Radić, $\mathrm{S}$.

Human Rights Watch 73, 85

Hungary

1102 union with Croatia 35-9, 172, 180 nationalism 44

see also Kossuth

IDS (Istarska Demokratska Sabor) Istrian

Democratic Assembly 76, 83-4, 96, 121-31

Ignatieff, M. 163, 164

Illyrian

movement in the nineteenth century $43-5,87,137,147,151,152,172$ 
peoples 35

Institut za Hrvatski Jezik I Jezikoslovlje (Institute of Croatian Language and Linguistics) 142

International Criminal Tribunal for the former Yugoslavia (ICTY) 80, 93

Istria 5, 39, 41, 46, 72, 92, 109, 138, 145$6,154,164,172-82$

contemporary regionalism 83-4, 12131

see also IDS

Ivas, I. 142-4, 146, 164

Ivkosić, M. 75

James, P. 1, 4, 5, 13, 15, 24-9, 165, 182-3

Jankovi, B. 37, 159

Jasenovac 52, 68, 70-1

Jedinstvo 49

Jelačić, J. 42-3, 74

Jelavich, C. 147

Jezik 139, 142, 144, 145

JNA, Jugoslavenski Narodna Armija

(Yugoslav Peoples Army) 3, 57, 74, $107,115,117,128,159$

Jonke, L. 138

Jukić, V. 78

Jurić, D. 112

Jutarnji List 145

Kajkavian dialect 44, 86, 145, 146, 172 see also language politics

Kale, E. 171

Kann, R. 41

Karadžić, V. S. 138, 141

Katunarić, V. 124

Kedourie E. 11, 15

Klapčić, N. 125-6

Klemenčić, M. 122, 130

Kossuth 38, 42

Kraglski Dalmatin 41

Krešimir, P. 36

Kricković, A. 117, 120

Kristo, J. 162

Kritika 55

Krleža, M. 48, 139, 152

Kuharić, Cardinal 156, 158-62, 179

Kuper, S. 113-14

Kustić, Z. 162
Kvarner 145

Kvaternik, E. 45, 76, 87

Lampe, R. 36

language politics 96, 137-46, 177 during Hungarian rule 43

Lerner, A. 20

Leroti, S. 113, 115

LS (Liberalna Stranka) Liberal Party 76, 81-2, 85, 88, 109

Luburić, M. 93

Maček, V. 49-54, 68, 82

Malkki, L. 20-3

Manolić, J. 77, 83

Marković, A. 108

Marmont, Marshal 40-1

Marulić, M. 152

Marxism 15, 153

Matica Hrvatska 44, 55, 138, 139, 142

Matica Srpska 138

McCrone, D. 24, 172

Meðugorje 163

Mesić, S. 4, 57, 77, 83

Mihailović, D. 54

Miloašević, S. 3, 4, 56-7, 72, 79, 88, 117, 159

Miroslav Krleža Lexicographical Institute 142

modernism 4, 7, 11-16, 24-6, 171, 173, 180-3

Mojzes, P. 159, 163

\section{Nacional 119}

Nagodba (compromise) 42-3, 45

Nairn, T. 7, 25, 174, 176

Napoleon 39-41

National Federation of Croatian Americans 95

NDH (Nezavisna Država Hrvatska) Independent State of Croatia 51-5, 70-1, 74, 94, 108, 138, 143, 150, 151

Novi List 127, 129, 145-6

Novi Sad language agreement 55, 138-40

O'Brien, C. 174

Oluja, Operation 3, 72, 79, 160-3 
Orthodox Church 45, 86, 156-9, 161, 163,179

OSCE 147, 150, 151, 153

OSI, Open Society Institute 154-6, 165, 175,177

Osijek 3, 74, 114

Ottoman Empire 37, 69

Pacta Conventa see Hungary, 1102 union with Croatia

Paraga, D. 77-8, 176

Partisan 148, 150, 151

Pavolić, A. 50-4, 66, 68-9

Perić, I. 150, 151, 171

Podgorelec, S. 117

Porphrygenitus, C. 34, 36

Portal, R. 33-4

Powers, G. F. 158

Pozzi, H. 49

Previsi, V. 149

primordialism 4, 7-11, 16, 24-6, 171-3, 180-3

Privredna Banka 107

Pukanić, I. 119

Pula 122, 125, 127-8

Puljić, V. 161

Pusić, V. 128

Radcliffe, S. 2, 20, 22, 23, 28, 29

Račan, I. 56, 76, 78-80

Račić, P. 49

Radi, P. 49, 84

Radić, S. 46-7, 49, 66, 70, 74, 83-4, 94, 96

Ramet, S. 124, 157-9

Rasković, J. 67

Ratković, R. 84

Raznatović, Z. 118

Rehn, E. 73

Renan, E. 9

re-traditionalism 149, 152, 153, 156, 164, $175-7$

Rijeka 48, 145

Rimac, I. 128, 130

Rohatinski, Ž. 111

Roman Catholic Church 5, 48, 86, 88, 96, 104, 156-65, 175, 176, 179-83

and Second World War 52-3

Rousseau, J. 8 ruralisation $164,175-7$

Sabol, Z. 86

Sabor 35, 37, 86, 143, 157

and Habsburgs 38-9

and HDZ 57, 109

and Hungary $37,42-3$

see also Nagodba

Safaryk, J. 34, 44

Sahovnica 36, 66

Sarajevo 73, 89, 161, 163

Schevill, F. 34

SDP (Socijalno Demokratska Partija)

Social Democratic Party 76, 78-82, 96, 109

Second World War 51-4, 150, 151, 157, 158

Sekereš, S. 140

Serbian Academy of Arts and Sciences 56

Seton-Watson, R. 48

SFRY, Socialist Federative Republic of Yugoslavia 3, 4

Shils, E. 8

Skerli, J. 138

Skiljan, D. 141, 142, 144, 144-6, 164

Slavonia 39, 43, 46, 50, 124, 145, 172

Slovenia 3, 160, 179, 182

Smith, A. 4, 7-11, 13, 22, 24, 147, 173

Soros, G. 120, 154, 165

Spalatin, C. 141, 142, 171

Split 33, 74, 117, 126, 144-5, 159, 176, 180

Starčević, A. 45, 66, 70, 76, 84, 86-7, 94, 96,173

State Institute for the Protection of Family, Maternity and Youth 148, 154,160

Stepinac, A. 52-5, 57, 70, 74, 157, 163

Storm, Operation see Oluja, Operation

Strossmayer, J. 44-5, 68, 74, 87, 152, 157

Sučić, D. S. 141

Suran, F. 123

Šegedin, P. 85

Šibenik 145

Škegro, B. 108

Škreb, M. 106

Štokavian dialect 41, 44-5, 138, 145, 146

see language politics 
Šufflay, M. 87

Šuker, D. 114-15

Šušak, G. 57, 69, 71, 83, 95

Šuvar, S. 55, 144, 147

Tanner, M. 33, 36, 53, 116, 171

Thompson, M. 69, 123, 125

Tito 3, 66, 70, 95, 139, 147, 150, 157, 163, 176,178

Tomac, Z. 119

Tomičić, Z. 85

Tomislav, King 35-6, 89

Tripalo, M. 76

Triune Kingdom 29, 36, 43, 50, 122

Trumbić, 45, 47-8

Tuðman, F. 4-6, 81, 85, 87-92, 96-8, 113-21, 143, 155-65, 172, 173, 175-81

and centuries-old dream 32, 43, 112 and opposition 80-5

rule in the 1990s 66-76, 78

Ugrešić, D. 84

Ujedinjeni Hrvati Njemačke (United Croats of West Germany) 94

Ujević, T. 152

United Nations 67, 73, 151, 161

UNPAS, United Nations Protected Areas 3

UNPROFOR, United Nations Protection Force 3

UNTAES, United Nations Transitional Authority in Eastern Slavonia 4, 75

Ustaša 50, 54, 66, 69-71, 76, 85-6, 89, 93-5, 107-8, 138, 147-8, 151, 157 crimes of $150,151,156,158$ Second World War 51-4

Vecernji List 108-9, 115, 145

Verdery, K. 5, 27, 29-30, 85

Veselica, M. 85, 105

Videšović, N. 110

Viduka, M. 114-15
Vitezović, P. 87

Vjesnik 137, 145, 149, 153

Vladovich, S. 34, 171-2

VMRO (Internal Macedonian Revolutionary Movement) 50

Vojna Krajina 39-41, 92, 157

Vojnić, D. 105

Vrcan, S. 159

Vujić, A. 78

Vukojević, Vice 143

Vukovar 3, 57, 78, 161

Warwick debate 4, 7, 20

Weber, M. 8, 12, 25

Westwood, S. 2, 20-9

Yugoslav League of Communists 50, 85, 107, 176

People's Army see JNA

Yugoslav Academy of Arts and Sciences 44, 139

Yugoslav Committee 47-8

Yugoslavism 143, 147, 176

Zadar 3, 145, 161

University 139

Zagreb 37, 44, 47-9, 51, 66, 72, 74, 83, 86, $88,96,105,112,118-21,124,137-$ $8,143-5,154-7,161-3,172,176$, 180

'crisis' (1995) 75

street names 71

Trg bana Jelačić 42

University of 51, 139, 152

Zagrebačka Banka 106

Zavod za Skolstvo 149

Živković, I. 156, 157, 158

Zrinskić, P. 152

Zupanov, J. 175

Zvonimir, King 37, 89, 143 